

\section{USO DE ROCHAGEM PELA MISTURA DE PÓ DE BASALTO E ROCHA FOSFATADA COMO FERTILIZANTE NATURAL DE SOLOS TROPICAIS LIXIVIADOS}

\section{RAFAEL TOSCANI GOMES DA SILVEIRA}

Banca Examinadora:

Prof. Dr. José Eloi Guimarães Campos (Universidade de Brasília)

Prof. Dr. Claudinei Gouveia de Oliveira (Universidade de Brasília)

Prof. Dr. Éder de Souza Martins (EMBRAPA - CPAC - Distrito Federal) 


\section{DEDICATÓRIA}

Ao feijão nosso de cada dia 


\section{AGRADECIMENTOS}

Gostaria de agradecer imensamente aos meus pais (Darwin e Denise) pelas milhares de horas despendidas no cuidado dos plantios, desde a semeadura até a colheita. Sem eles este trabalho com certeza não teria nem a metade dos dados aqui apresentados.

Agradeço ao meu irmão Bruno e a minha querida namorada Débora pelo apoio e por ter aguentado momentos estressantes na divisão do tempo entre academia, trabalho e lazer. Além disso, aos meus tios e a todos que torcem por mim.

Ao meu orientador pela grande disponibilidade e por alguns fins de semanas dedicados a agricultura.

Ao meu amigo Rafael Grudcka pelas várias horas comigo em frente ao monitor de difratometria de raios- $\mathrm{X}$, em busca das mais variadas descobertas da mineralogia dos solos. Neste âmbito vale lembrar os amigos e profissionais que passaram do início até o fim desta dissertação.

Por fim, e não menos importante (longe disso) gostaria de reconhecer imensamente a ajuda de uma energia superior, que engloba também meus entes queridos falecidos, especialmente representados pela minha querida e eterna Vó Marlize e Tio Cirilo. 
EPÍGRAFE

Todo ser humano acha que está certo... mas quem está certo mesmo sou eu (Vó Marlize). 


\section{Sumário}

USO DE ROCHAGEM PELA MISTURA DE PÓ DE BASALTO E ROCHA FOSFATADA COMO

FERTILIZANTE NATURAL DE SOLOS TROPICAIS LIXIVIADOS …........................................................ USO DE ROCHAGEM PELA MISTURA DE PÓ DE BASALTO E ROCHA FOSFATADA COMO FERTILIZANTE NATURAL DE SOLOS TROPICAIS LIXIVIADOS ..............................................................i

RESUMO

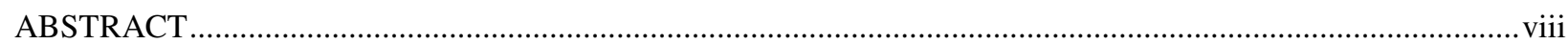

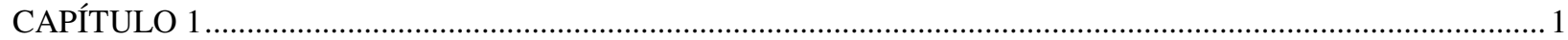

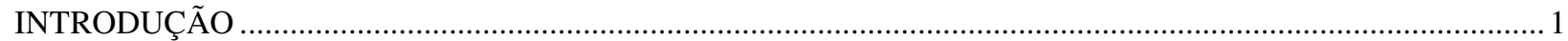

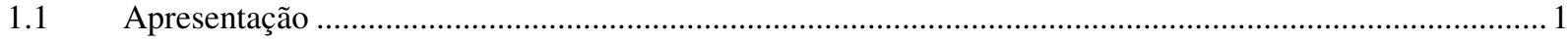

1.2 Panorama Econômico Brasileiro dos Fertilizantes .......................................................................... 4

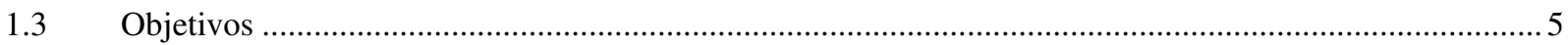

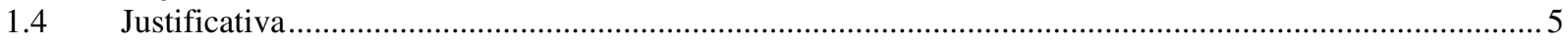

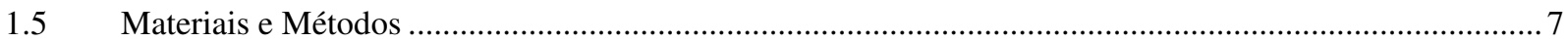

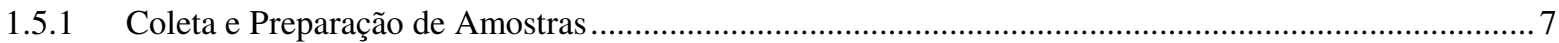

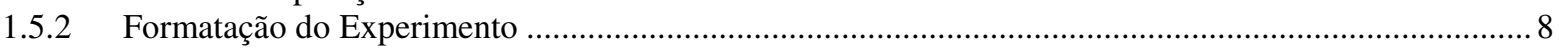

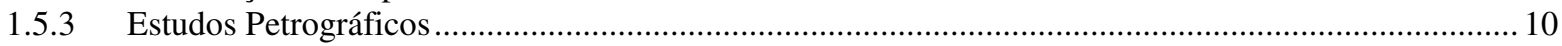

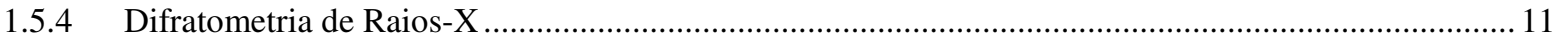

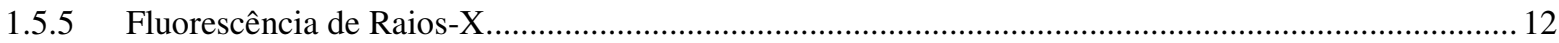

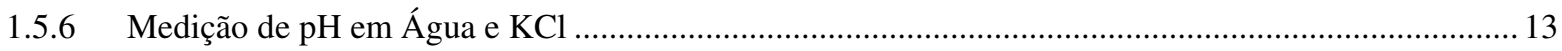

1.5.7 Elementos Disponíveis (Análise de Fertilidade do Solo) ........................................................... 13

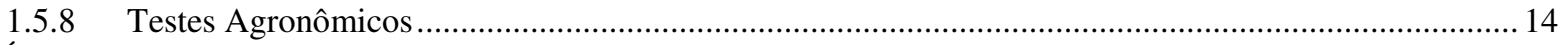

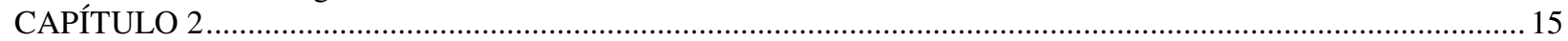

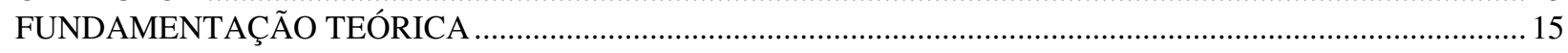

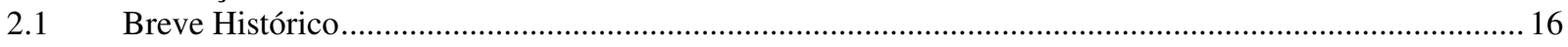

2.2 Histórico da Utilização das Rochas Silicáticas Multi-nutricionais .................................................... 17

2.3 Histórico da Utilização das Rochas Mono-nutricionais.................................................................. 19

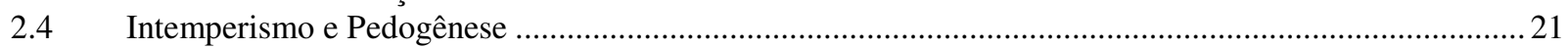

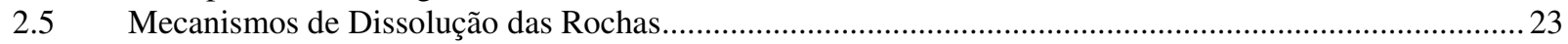

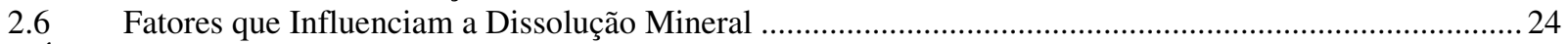

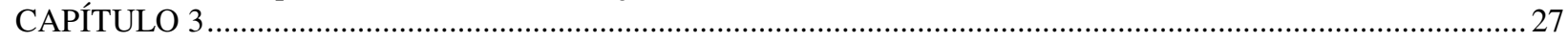

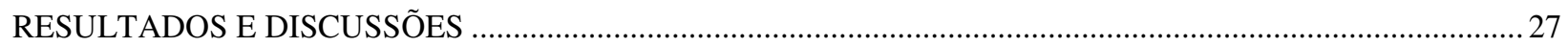

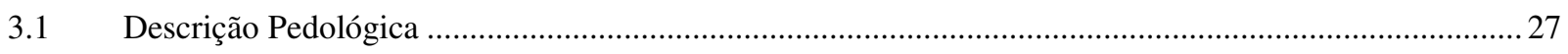

3.2 Descrição Mineralógica dos Pós Aplicados na Rochagem ................................................................29

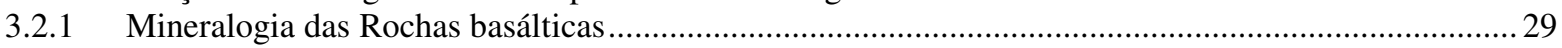

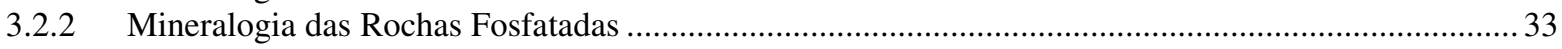

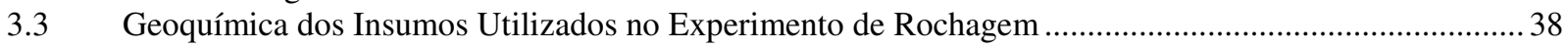

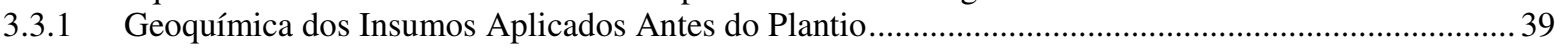

3.3.2 Geoquímica de Fluorescência de Raios-X Durante um Ano de Plantio.............................................42

3.3.3 Geoquímica de Fertilidade do Solo Após um Ano de Plantio..........................................................45

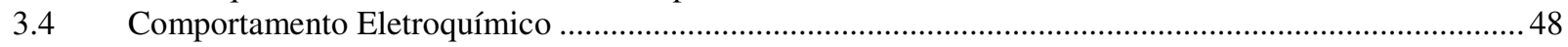

3.5 Análise Mineralógica do Experimento Durante um Ano.................................................................54

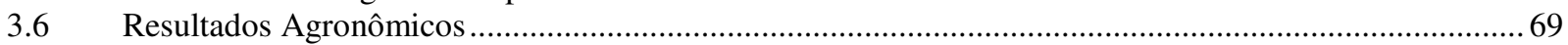

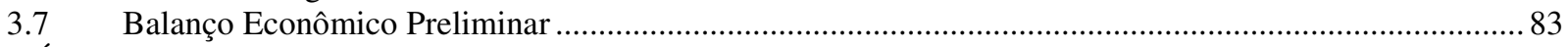

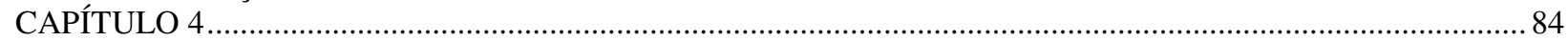

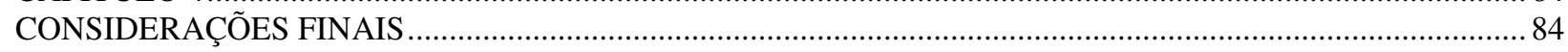

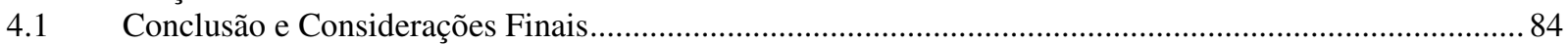

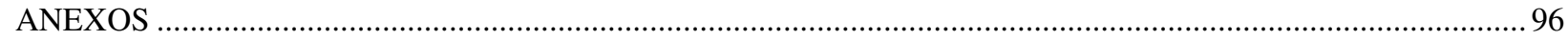




\section{RESUMO}

A rochagem consiste na utilização de pós de rocha como fertilizante natural para a agricultura, disponibilizando de forma direta os nutrientes presentes nos minerais para as plantas. No presente experimento utilizaram-se pós de fosforito, basalto e dolomito fosfatado os quais foram comparados com os fertilizantes solúveis $(40 \mathrm{~N}, 30 \mathrm{P}, 10 \mathrm{~K})$ e o Latossolo controle. No total foram construídas doze parcelas de plantio sobre o Latossolo Vermelho distrófico com diferentes proporções e misturas dos insumos, sendo que foi testada também a necessidade ou não da calagem para o melhor desenvolvimento do plantio de feijão vagem (Phaseolus vulgaris L.). Para a compreensão mineralógica do material realizaram-se lâminas petrográficas e difratometria de raios-X. Para o entendimento da geoquímica do solo usaram-se técnicas de fluorescência de raios-X e análises padrão de fertilidade do solo. Ainda, realizaram-se estudos agronômicos por meio de medições da área foliar e o peso das produções. O estudo mineralógico indicou que o uso da rochagem adicionou ao solo fluorapatita, vermiculita, montmorilonita, dolomita, anortita, augita e albita. Estes minerais são importantes do ponto de vista agronômico, pois podem ser fontes principalmente de fosfato, cálcio, sódio e magnésio. A geoquímica do solo permitiu avaliar que nas parcelas com uso exclusivo de rochagem houve uma disponibilidade e/ou lixiviação dos óxidos de potássio, fósforo e enxofre 2,14 vezes maior que nos canteiros com uso da rochagem e calagem. Entretanto, isto não se reflete na melhor resposta agronômica, pelo contrário, nos canteiros onde houve uso de calagem os resultados agronômicos foram muito mais interessantes devido ao melhor equilíbrio iônico com o aumento do ponto de carga zero (PCZ). De forma geral, o uso dos pós de rocha aumentaram o $\mathrm{pH}$ e a saturação por bases de modo bastante rápido já no primeiro plantio. Além disso, diminuíram a saturação por alumínio, a matéria orgânica e o carbono. Por fim, o uso da rochagem apresenta importante efeito remanescente, sendo as reaplicações menos imperativas que no caso dos fertilizantes solúveis. Nota-se ainda menor necessidade do uso da calagem nos canteiros onde se aplicou pós de rocha em comparação àqueles em que se utilizou NPK.

Palavras-chave: rochagem, fertilização alternativa. 


\begin{abstract}
The present research study the use of rock powders as natural fertilizer for agriculture, providing directly nutrients present in the minerals to the plants. In this experiment powders of phosphorite, basalt and phosphate dolostone were compared with soluble fertilizers $(40 \mathrm{~N}, 30 \mathrm{P}$, $10 \mathrm{~K})$ and the control Reddish Oxisol. Twelve planting parcels on the distrophic Reddish Oxisol with different proportions and mixtures of inputs, and was also tested the necessity of using carbonate rock powder for the better development leguminous beans (Phaseolus vulgaris l.). For the understanding of the mineralogy of the material thin sections and X-ray diffractometry analysis were performed. For the understanding of the geochemistry of soil, X-ray fluorescence techniques and standard analysis of soil fertility were developed. Agronomic efficiency studies were carried out by measurements of leaf area and the weight of the production. The mineralogy study indicated that the use of stonemeal added to the soil fluorapatite, vermiculite, montmorillonite, dolomite, anorthite, augite and albite. These minerals are important by the agronomic point of view as they can be primarily sources of phosphate, calcium, sodium and magnesium. Soil geochemistry of the parcels exclusive submitted to rock powder fertilization shows that there was availability and/or leaching of Potassium, Phosphate and Sulfur oxides, 2.14 times greater than in the sites with use of rock powder together to carbonate powder. However, it is not reflected in greater agronomy efficiency, by the opposite, in the parcels where the rock powder was used, the agronomic results were much more interesting due to the better ionic balance with increased Point of Zero Charge (PZC). In General, the use of rock powders raised the $\mathrm{pH}$ and the saturation of bases fast enough so that the results were felt in the first planting. In addition, the results show decreasing in the aluminum saturation, organic matter and carbon. Finally, the use of rock powder presents important remaining effect, being the reapplication less necessary that in the case of soluble fertilizers. It is still possible to note that the parcel where the rock powder was applied was necessary to use less $\mathrm{pH}$ neutralization products in comparison to those where the soluble fertilizers were used.
\end{abstract}

Keywords: rock powder, alternative fertilization. 


\section{CAPÍTULO 1 INTRODUÇÃO}

\subsection{Apresentação}

No Brasil a forma de fertilização mais comum é a partir de fontes convencionais de nutrientes $(\mathrm{FCN})$ que são basicamente fertilizantes solúveis como o NPK (mistura de diferentes concentrações de nitrogênio, fósforo e potássio), além de outros micronutrientes específicos para cada tipo de solo e cultura.

Esta adubação tem como principal vantagem a rápida disponibilização de nutrientes para as plantas e foi conhecida historicamente e internacionalmente como a "revolução verde" nas décadas de 40 a 60 e representou um significativo avanço na produção de alimentos. Baseou-se na melhoria genética de variedades de culturas, apoiado por insumos agroquímicos, como fertilizantes, pesticidas e herbicidas e também o avanço nas técnicas de irrigação (Conway 1997, Van Straaten 2006). Entretanto, nos últimos anos a taxa de aumento de produção tem diminuindo consideravelmente. No Brasil essa revolução se deu na década de 70 e possibilitou a produção agrícola em solos tropicais profundos e muito pobres em nutrientes, em especial no Bioma Cerrado. Contudo, este sistema de exploração acarretou numa gama variada de problemas ambientais que motivaram questionamentos sobre a sustentabilidade das técnicas agrícolas tradicionais em um ecossistema frágil como o cerrado (Shiki et al. 1997, Martins et al. 2010)

Os fertilizantes solúveis não foram desenvolvidos para climas tropicais, onde predominam um sistema geoquímico do tipo $\mathrm{Fe}_{2} \mathrm{O}_{3}-\mathrm{A}_{2} \mathrm{O}_{3}-\mathrm{SiO}_{2}-\mathrm{H}_{2} \mathrm{O}$ pobre em nutrientes e de baixa capacidade de troca catiônica, necessitando uma gama de macro e micronutrientes não frequentemente presentes na adubação convencional (Leonardos et al. 1987). Na realidade, esta fertilização foi desenvolvida de modo a ser um aditivo para a nutrição dos solos de clima temperado que já apresentam uma reserva mineral importante. Além disso, no clima temperado, as precipitações (chuva e neve) são bem distribuídas, minimizando perdas por lixiviação (Leonardos et al. 1976).

Baligar et al. (2001) relatam a eficiência nutricional do uso de fontes convencionais de nutrientes no ano de aplicação de aproximadamente $50 \%$ de $\mathrm{N}$, menos de $10 \%$ para o P e cerca de $40 \%$ para o K. Deste modo, a aplicação é necessária praticamente em cada safra de ciclo anual, especialmente em climas tropicais, aumentando os gastos com a fertilização que chegam a cerca de $40 \%$ dos custos variáveis de produção (Martins et al. 2008). Somado a este fato, a elevada solubilidade faz com que os nutrientes não assimilados pelas culturas migrem rapidamente com risco de contaminação das águas superficiais e subterrâneas. 
Desta maneira, outros métodos de adubação merecem ser testados e utilizados. A agrogeologia em que está inserida a técnica da rochagem é um dos instrumentos biofísicos que são utilizados para combater problemas dos solos em longo prazo (Van Straaten 2006).

A rochagem é baseada na utilização de rochas e ou minerais constituintes das rochas como fornecedores dos nutrientes necessários para as plantas (Leonardos et al. 1976). Para esse tipo de fertilização é essencial combinar a mineralogia e geoquímica da rocha selecionada com as exigências do solo e das plantas.

Esse método tem sua eficiência indiretamente comprovada há milênios, visto que regiões de processos tectônicos e geológicos ativos como os arcos magmáticos apresentam historicamente boa fertilidade, onde elementos crustais como $\mathrm{Si}, \mathrm{A} 1, \mathrm{~K}, \mathrm{Na},(\mathrm{Ca}), \mathrm{Be}, \mathrm{Li}, \mathrm{Zn}$, Mo, F e B são misturados com elementos de origem mantélica como $\mathrm{Ca}, \mathrm{Mg}, \mathrm{Cu}, \mathrm{Co}, \mathrm{Ni}, \mathrm{S}, \mathrm{V}$, Cr e Se (Leonardos et al. 1987). Já as regiões tectonicamente estáveis, apresentaram um espectro nutricional muito mais restrito devido à intensa lixiviação e baixa erosão. No Brasil podem-se citar os solos mais férteis relacionados com rochas vulcânicas basálticas e alcalinas de Rio Verde (GO) e os tufos do Grupo Mata da Corda em Patos de Minas (MG) (Leonardos et al. 1976).

Deste modo, o uso do pó de rocha poderia contribuir de modo mais complexo e equilibrado com adição de macro e micro-nutrientes aos solos intensamente lixiviados. Macronutrientes como $\mathrm{Mg}, \mathrm{Ca}, \mathrm{K}$ e $\mathrm{P}$ podem ser encontrados em basaltos, dunitos, sienitos, dolomitos, fosforitos, entre outros (exceção do nitrogênio). Geralmente também apresentam elementos traços como Co, Zn e Cr (Van Straaten 2006).

Como comparativo entre a fertilização convencional e a rochagem, podem-se enfatizar cinco variáveis, explanadas por Bergsma et al. 2009.

- Nutrientes: os fertilizantes solúveis ainda que disponibilizem rapidamente os nutrientes para as plantas, causam o aumento repentino das ligações iônicas no solo úmido, seguido de uma rápida troca e lixiviação dos cátions (Ernani 1996, Yanai et al. 1998).

Já o uso de estrume é normalmente rico em amônia sendo agressivo para a vegetação e aos microrganismos. Esse material diminui o pH do solo e aumenta a lixiviação de elementos traços importantes.

O uso de fragmentos de rochas apresenta uma disponibilidade mais lenta dos nutrientes, de modo que a lixiviação dos elementos seja mais amena. Outro fato importante é que o material não é agressivo aos microrganismos e mantém ou aumenta o $\mathrm{pH}$ do solo. Além disso, são encontrados nas rochas 18 dos 19 elementos essenciais para o crescimento das plantas (Malavolta 2008). Neste caso, é interessante notar que os insumos convencionais focam especialmente nos elementos principais como nitrogênio, potássio e fósforo deixando, em segundo plano, elementos secundários (Fe, Mn, Zn, Cu, Mo, Co, Ni, B, Cl, Se) que são fundamentais para o pleno desenvolvimento das culturas. 
- Atividade orgânica: é reconhecido que as relações de benefícios entre microrganismos e o solo são reduzidas com a adubação tradicional. Como exemplo tem-se a diminuição da simbiose entre micorrizas e o sistema radicular das plantas. Além disso, a utilização indiscriminada de nitrogênio inorgânico pode causar uma grande perda da matéria orgânica visto que algumas espécies são desfavorecidas com a elevada quantidade de nutrientes (McCarty \& Meisinger 1997, Malý et al. 2009).

$\mathrm{O}$ uso de pó de rocha apresenta importante equilíbrio com os microrganismos. Neste contexto seres vivos como as micorrizas são responsáveis por dissolver e distribuir os elementos contidos nos minerais.

- Qualidade dos produtos agrícolas: uma revisão de 14 artigos feito por Heaton (2001) mostra que apenas $7,14 \%$ dos estudos indicam que o cultivo tradicional apresenta mais minerais nas plantas que o cultivo orgânico, sendo que 50\% dos artigos indicam o contrário e 42,85\% não são conclusivos.

Mais especificamente Brandt \& Molgaard's (2001) estimaram que a produção não convencional de vegetais tende a apresentar 10-50\% de componentes secundários a mais que os das fontes convencionais de nutrientes (FCN). Além disso, nutrientes primários como vitamina $\mathrm{C}$, matéria seca e minerais essenciais apresentam maiores teores nas produções orgânicas (Heaton 2001).

- Pragas e doenças: a agrogeologia possui relativa complexidade dos elementos presentes nos minerais aplicados. Deste modo, há uma maior proteção a doenças, ataques e danos às plantas, pois muitos elementos secundários estão relacionados com o sistema imunológico da planta (Heaton 2001).

Ainda, como o uso dos FCN desequilibra a relação mutualística com as micorrizas, há uma maior probabilidade de desenvolvimento de doenças (Corkidi et al. 2002).

- Consumo de energia e emissão de gases do efeito estufa: o uso de fertilizantes representa $45 \%$ da energia utilizada na agricultura. Estima-se que a produção de fertilizantes é responsável por 0,6 a 1,2\% do total das emissões de gases do efeito estufa (GEE) (Bellarby et al. 2008).

Como a produção desses insumos é realizada em países desenvolvidos, o valor de transporte para continentes como América do Sul e África é elevadíssimo, chegando a mais de cinco vezes do valor original. Esse alto custo, por vezes inviabiliza a agricultura em pequena escala (Van Straaten 2006).

A fertilização com uso de pó de rocha necessita de menor quantidade de energia para ser produzida ainda que tenha gastos no processo de fragmentação e moagem. Embora a 
rochagem necessite de uma alta tonelagem por hectare, os elementos são lentamente liberados no solo de modo a precisar de um número reduzido de aplicações, consequentemente, de um custo menor de transporte e de aplicação. Além disso, a grande abundância e a ocorrência bem distribuída no território nacional permitem sua utilização regional da mesma forma que o calcário agrícola (Martins et al. 2010). Por fim, alguns estudos indicam que o uso de rocha silicática pode sequestrar $\mathrm{CO}_{2}$ da atmosfera (Hartmann \& Kempe 2008).

\subsection{Panorama Econômico Brasileiro dos Fertilizantes}

No panorama econômico mundial, o Brasil é o quarto consumidor mundial de fertilizantes do tipo NPK com 9\% do mercado, atrás da China, Índia e EUA, cada um representando 48\%, 23\% e 20\%, respectivamente (Kulaif \& Fernandes 2010).

Para se entender a abrangência do problema, atualmente $70 \%$ do total dos fertilizantes utilizados no país são derivados de fontes convencionais de nutrientes importadas compostas, essencialmente de variantes de NPK de elevada concentração e alta solubilidade (Medeiros 2013). Vale ressaltar que no Brasil mais de $60 \%$ das organizações agropecuárias não empregam qualquer tipo de fertilizante (Luz et al. 2010).

Para piorar a já frágil situação, o aumento no uso de fertilizantes convencionais no Brasil não acompanha o seu ritmo de produção, puxando as importações para níveis mais altos (Figura 1.1, Kulaif \& Fernandes 2010). O único segmento que se difere um pouco é relacionado ao fosfato, onde nas últimas décadas foram descobertas importantes reservas minerais, mesmo assim, Rodrigues (2009) em um cálculo simplificado infere que a vida útil das jazidas brasileiras de $\mathrm{P}_{2} \mathrm{O}_{5}$ seja pouco superior a três décadas.

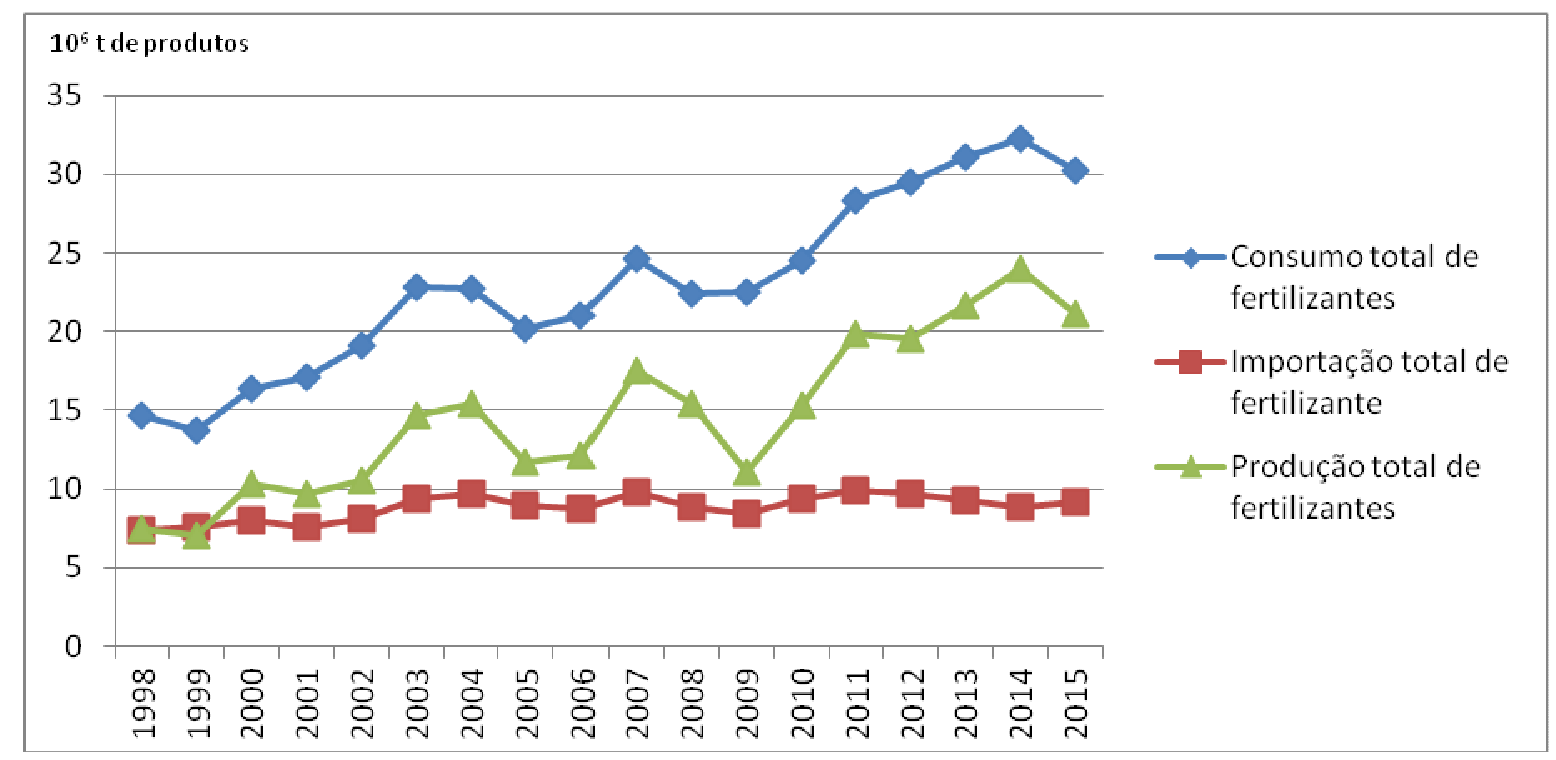

Figura 1.1 - Gráfico ilustrando as taxas de consumo, importação, produção e exportação dos fertilizantes do tipo NPK ao longo dos anos no Brasil (com dados dos Anuários ANDA, 1998 a 2015). 


\subsection{Objetivos}

O principal objetivo do presente estudo é determinar a mineralogia e geoquímica do solo antes e depois da aplicação de diversos insumos como a adição de rochas basálticas (Formação Serra Geral), fosforito e dolomito fosfatado (Grupo Bambuí), além de NPK e calagem. Esta etapa visa compreender o comportamento mineralógico ao longo do ano e determinar os resíduos ativos nos solos.

Além disso, o potencial agronômico dos minerais é avaliado por meio de parâmetros simples, porém contundentes, como a medição da área foliar e o acompanhamento da evolução de cada plantio. Sendo assim, se objetiva comparar os resultados da rochagem com áreas sem nenhum tipo de fertilização e áreas em que serão aplicados fertilizantes solúveis como NPK comercial. Nesta comparação, todas as misturas de rochas tiveram seus experimentos realizados com e sem calagem, para determinar o potencial de regulação do $\mathrm{pH}$.

Por fim, pretende-se realizar um balanço econômico preliminar comparando a aplicação de fertilizantes solúveis com o pó da mistura proposta e as variáveis de viabilidade (ex. custo de produção, distância máxima de transporte e ganhos em produtividade).

\subsection{Justificativa}

Em países de clima temperado como Alemanha e Estados Unidos práticas de agricultura orgânica são relativamente comuns, sobretudo no uso para a fertilização de solos afetados por ação antrópica, como as florestas da Europa central que foram afetadas por chuva ácida (Van Straaten 2006).

Nestes países publicações a respeito de agrominerais já têm um importante histórico, entretanto, em países tropicais como o Brasil, a produção bibliográfica a este respeito é relativamente pequena. Estes estudos se concentram em testes agronômicos a fim de verificar a competitividade agrícola se comparado com insumos convencionais. Deste modo, trabalhos envolvendo caracterização mineralógica e geoquímica das rochas e do solo são mais raros.

Este quadro é preocupante, visto que justamente em países tropicais os resultados agrícolas positivos são mais significativos, especialmente relacionados a rochas silicáticas ferromagnesianas (Van Straaten 2006).

Isso ocorre devido ao elevado processo de intemperismo ocasionado por temperatura e precipitação elevadas, que resultam em solos ácidos com caráter distrófico, alumínico, ácrico, alítico e de pH ácido (EMBRAPA, 2006). Deste modo, a aplicação de agrominerais é eficiente, pois este ambiente permite a dissolução de grande volume de minerais silicáticos (Van Straaten 2006).

Neste estudo foram escolhidos três tipos de rochas para o processo de fertilização, sendo elas o basalto, o fosforito e o dolomito fosfatado. 
A escolha destes materiais é justificada pela presença de minerais que são ricos em nutrientes essenciais para as plantas, além disso, em um raio de 250 quilômetros estes três tipos de rochas podem ser encontradas, o que facilita na logística e diminuição do custo de aplicação. Considerando apenas a região de Arraias os três tipos de rochas podem ser obtidas em apenas uma área de $2 \mathrm{~km}^{2}$.

O basalto extraído do Município de Araguari estado de Minas Gerais possui mineralogia relativamente complexa a qual pode apresentar importante papel na interação com o solo e disponibilização de nutrientes importantes como Ca, $\mathrm{Na}$ e $\mathrm{Mg}$. Assim sendo, com o avançar do intemperismo desta rocha, pode ocorrer a neoformação de argilominerais com estrutura 2:1 os quais apresentam inúmeras vantagens para o desenvolvimento físico, biológico e químico do solo. Estes minerais podem aumentar a CTC (capacidade de troca catiônica) do solo bem como a capacidade de retenção de água e a diminuição da perda de nutrientes por lixiviação. Por fim, aumentam a resistência a mudança em pH, reduzindo a necessidade de calagem (Troxler 1999).

Os fosfatos de origem sedimentar retirados do município de Arraias no estado do Tocantins apresentam teores de $\mathrm{P}_{2} \mathrm{O}_{5}$ variando de $11 \%$ a $34 \%$ os quais são muito interessantes para a agricultura. A mineralogia da apatita primária é representada pela francolita, porém processos intempéricos transformam sua estrutura, assumindo características similares a da fluorapatita (Monteiro, 2009). No presente estudo, foram selecionadas rochas fosfatadas de origem sedimentar devido a sua maior eficiência agronômica se comparado às rochas de origem ígnea (Léon et al. 1986, Gholizadeh et al. 2009). Ainda, os fosforitos ígneos embora apresentem menor quantidade de urânio oriundo do processo da substituição iônica nos cristais carbonatofluoroapatíticos ou por adsorção, apresentam teores significativos de micronutrientes contaminantes como ETR, Nb e F (Levinson, 1974).

Por fim, a última rocha utilizada no processo de remineralização do solo é proveniente da região de Taipas, estado do Tocantins e é definida como um dolomito fosfatado que apresenta teores significativos de $\mathrm{Ca}$ e $\mathrm{Mg}$ com pequeno teor de $\mathrm{P}$ e outros micronutrientes. Deste modo, esta rocha pode além de corrigir o $\mathrm{pH}$ do solo, de modo similar a calagem, contribuir com nutrientes importantes para a planta.

Vale ressaltar que os materiais utilizados tiveram um processamento mínimo, sendo que somente o dolomito fosfatado necessitou de moagem, o basalto foi coletado a partir de rejeitos de pedreira para produção de agregados para construção civil e o fosforito brechado foi coletado em um estágio bastante decomposto por processos naturais. 


\subsection{Materiais e Métodos}

A metodologia aplicada apresentou dois focos principais, o primeiro, foi analisar a resposta agronômica comparando as áreas com as diferentes misturas de pó de rocha, fertilizante solúvel e a utilização ou não de calagem. O segundo enfoque é relacionado com análise do solo e do material aplicado, incluindo aspectos como $\mathrm{pH}$, mineralogia e geoquímica.

No estudo foram realizados três repetições de plantio (12/11/14 a 12/01/15, 21/03/15 a 30/05/15 e 28/11/2015 a 06/02/2016). Consequentemente, três baterias de fluorescência e difratometria de raios- $\mathrm{X}$ foram realizadas, assim como os seus respectivos testes agronômicos.

A seguir são detalhados os procedimentos realizados no presente estudo.

\subsubsection{Coleta e Preparação de Amostras}

As rochas de origem sedimentar ricas em fosfato foram extraídas da base da Formação Sete Lagoas (Grupo Bambuí) dos municípios de Arraias e Taipas (TO), já as rochas basálticas foram retiradas nas proximidades de Araguari (MG) e pertencem a Formação Serra Geral. Vale salientar que a granulometria usada foi propositalmente variada, a fim de facilitar a possível visualização de processos de neoformação bem como disponibilizar os nutrientes de forma mais eficiente (Figura 1.2).

Esta disponibilização mais rápida ou similar se comparado a pós de rocha de granulometria mais fina está de acordo com experimentos e relatos de autores como Niwas et al. (1987), Blum et al. (1989) e Harley \& Gilkes 2000).

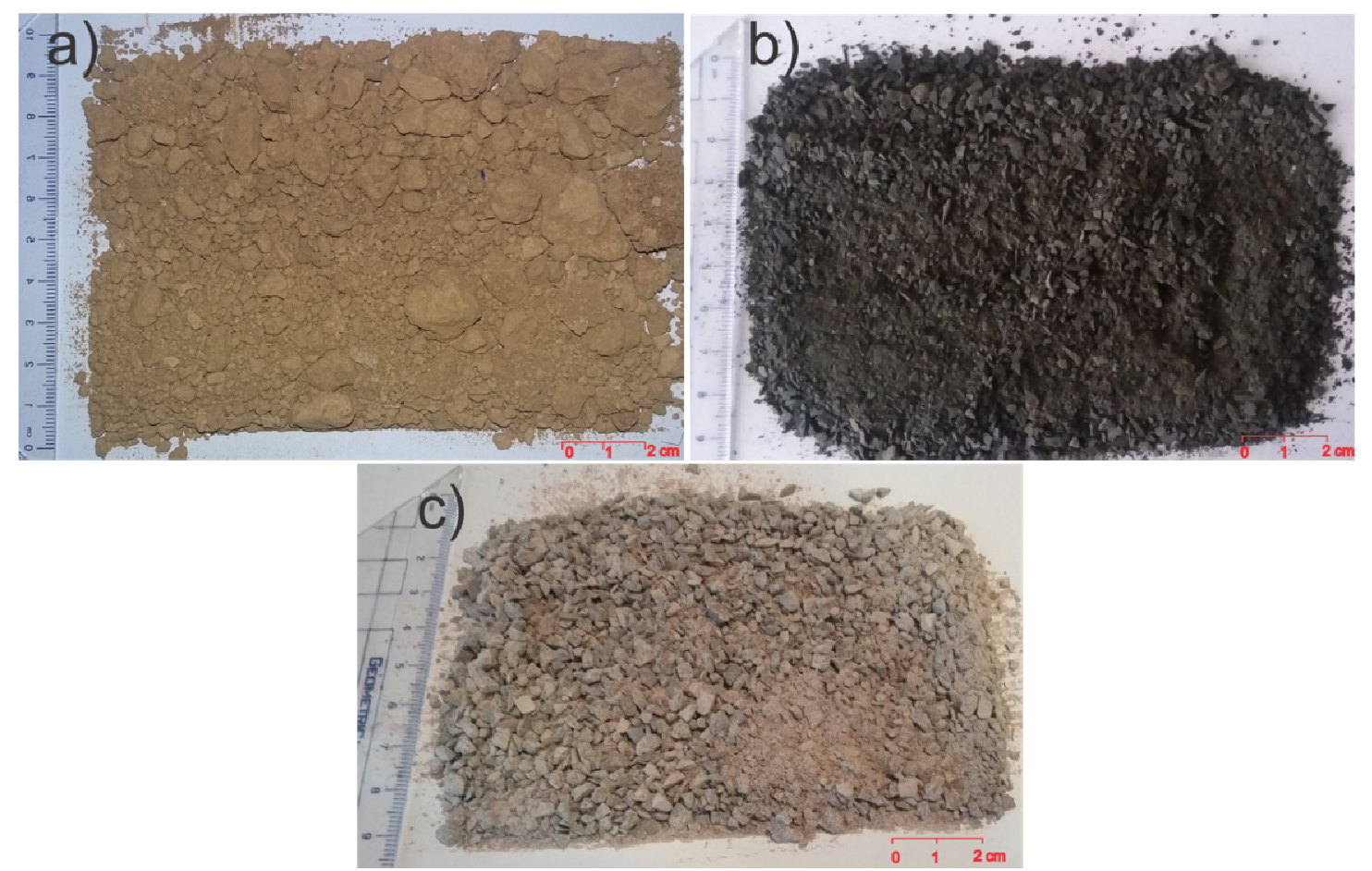

Figura 1.2 - Aspecto granulométrico das rochas utilizadas no processo de rochagem. Notar a granulometria bastante variada desde filler até farelado grosso. a) Fosforito. b) Basalto. c) Dolomito fosfatado. 
Foi realizado estudo granulométrico das três rochas utilizadas no processo de rochagem com a divisão nas granulometrias argila, silte e areia. A fração areia foi subdividida em areia média e muito grossa.

O fosforito utilizado no presente estudo foi coletado em uma trincheira pertencente ao Alvo Bomfim relativo a pesquisa mineral realizada pela empresa DuSolo Fertilizantes LTDA. Esse material não passou por processo de moagem, sendo já coletado num estado inconsolidado devido a processos intempéricos. Sua granulometria majoritária é de silte seguido por argila (Tabela 1.1).

O dolomito fosfatado, extraído da região de Taipas, apresenta-se pouco alterado, bastante coeso, necessitando passar por processo de moagem. Sua granulometria apresenta maiores proporções de silte seguido por areia (Tabela 1.1).

O basalto foi coletado como rejeito de uma pedreira de agregados miúdos. O material teve sua granulometria majoritária de silte seguido por areia (Tabela 1.1).

Tabela 1.1 - Análise granulométrica dos pós de rocha de Basalto, Fosforito Brechado e Dolomito Fosfatado.

\begin{tabular}{|l|c|c|c|c|}
\hline $\begin{array}{l}\text { Composição } \\
\text { Granulométria (g/kg) }\end{array}$ & Diâmetro do Grão (mm) & Basalto & Fosforito & $\begin{array}{c}\text { Dolomito } \\
\text { Fosfatado }\end{array}$ \\
\hline Argila & $<0,002$ & 125,0 & 475,0 & 150,0 \\
\hline Silte & $0,05-0,002$ & 861,266 & 521,941 & 831,394 \\
\hline Areia & $>0,002$ & 750,0 & 250,0 & 800,0 \\
\hline Areia média & 0,50 a 0,20 & 5,075 & 0,272 & 2,88 \\
\hline Areia muito grossa & 1,0 a 2,0 & 8,659 & 2,787 & 15,726 \\
\hline
\end{tabular}

\subsubsection{Formatação do Experimento}

Inicialmente foi realizada a descrição pedológica do solo por meio de uma pequena trincheira, sendo caracterizado como um Latossolo Vermelho de textura muito argilosa.

Posteriormente, no dia 28/09/2014 houve o preparo da terra em onze blocos de $4 \mathrm{~m}^{2}$, com aragem de forma manual, seguido de aplicação de fosforito e dolomito fosfatado oriundos do Grupo Bambuí, basalto oriundo da Formação Serra Geral e NPK (4:30:10) (Tabela 1.2). Neste procedimento, metade dos canteiros foram submetidas a calagem, com objetivo de verificar e comparar o poder de correção do pH dos insumos aplicados.

No experimento foram revolvidos $20 \mathrm{~cm}$ do solo e aplicados uma camada de pós de rocha com espessura aproximada de $3 \mathrm{~cm}$, o qual corresponde a uma concentração de $15 \%$ do volume.

Vale ressaltar que a tonelagem utilizada é bastante elevada, sendo experimentos de hiperaplicação importantes, pois permitem refletir períodos longos de aplicação correspondentes aproximadamente há uma década. No caso dos experimentos onde houve aplicação de $140 \mathrm{~kg}$ de pó de rocha, seria equivalente a uma concentração de 350 ton.ha ${ }^{-1}$, na aplicação de $120 \mathrm{~kg}$ de 300 ton.ha ${ }^{-1}$ e para $100 \mathrm{~kg}$ de 250 ton.ha ${ }^{-1}$. 
Tabela 1.2 - Disposição dos canteiros com suas respectivas quantidades e tipos de insumos aplicados.

\begin{tabular}{|c|c|c|c|c|c|c|c|c|c|c|c|}
\hline \multicolumn{10}{|c|}{ Canteiros $\left(4 \mathrm{~m}^{2}\right)$} \\
\hline 1 & 2 & 3 & 4 & 5 & 6 & 7 & 8 & 9 & 10 & 11 & 12 \\
\hline NPK & $\begin{array}{c}\text { NPK } \\
+\mathrm{C}\end{array}$ & $\mathrm{F}(120 \mathrm{~kg})$ & $\begin{array}{c}\mathrm{F}(120 \mathrm{~kg}) \\
+\mathrm{C}\end{array}$ & $\begin{array}{c}\mathrm{F}(60 \mathrm{~kg}) \\
+ \\
\mathrm{B}(80 \mathrm{~kg})\end{array}$ & $\begin{array}{c}\mathrm{F}(60 \mathrm{~kg}) \\
+ \\
\mathrm{B}(80 \mathrm{~kg}) \\
+\mathrm{C}\end{array}$ & $\begin{array}{c}\mathrm{F}(20 \mathrm{~kg}) \\
+\end{array}$ & $\begin{array}{c}\mathrm{F}(20 \mathrm{~kg}) \\
+\end{array}$ & $\begin{array}{c}\mathrm{B}(120 \mathrm{~kg}) \\
\mathrm{B}(80 \mathrm{~kg}) \\
+\mathrm{C}\end{array}$ & $\begin{array}{c}\mathrm{B}(120 \mathrm{~kg}) \\
+\mathrm{C}\end{array}$ & $\begin{array}{c}\mathrm{DF} \\
(120 \\
\mathrm{kg})\end{array}$ & $\begin{array}{c}\mathrm{L} \\
\text { Onde: C = Calagem, F = Fosforito, B = Basalto, DF = Dolomito Fosfatado, L = Latossolo }\end{array}$ \\
\hline
\end{tabular}

Na Figura 1.3 são ilustrados de forma esquemática os 12 canteiros utilizados no experimento, onde se podem visualizar as diferentes misturas com suas proporções.

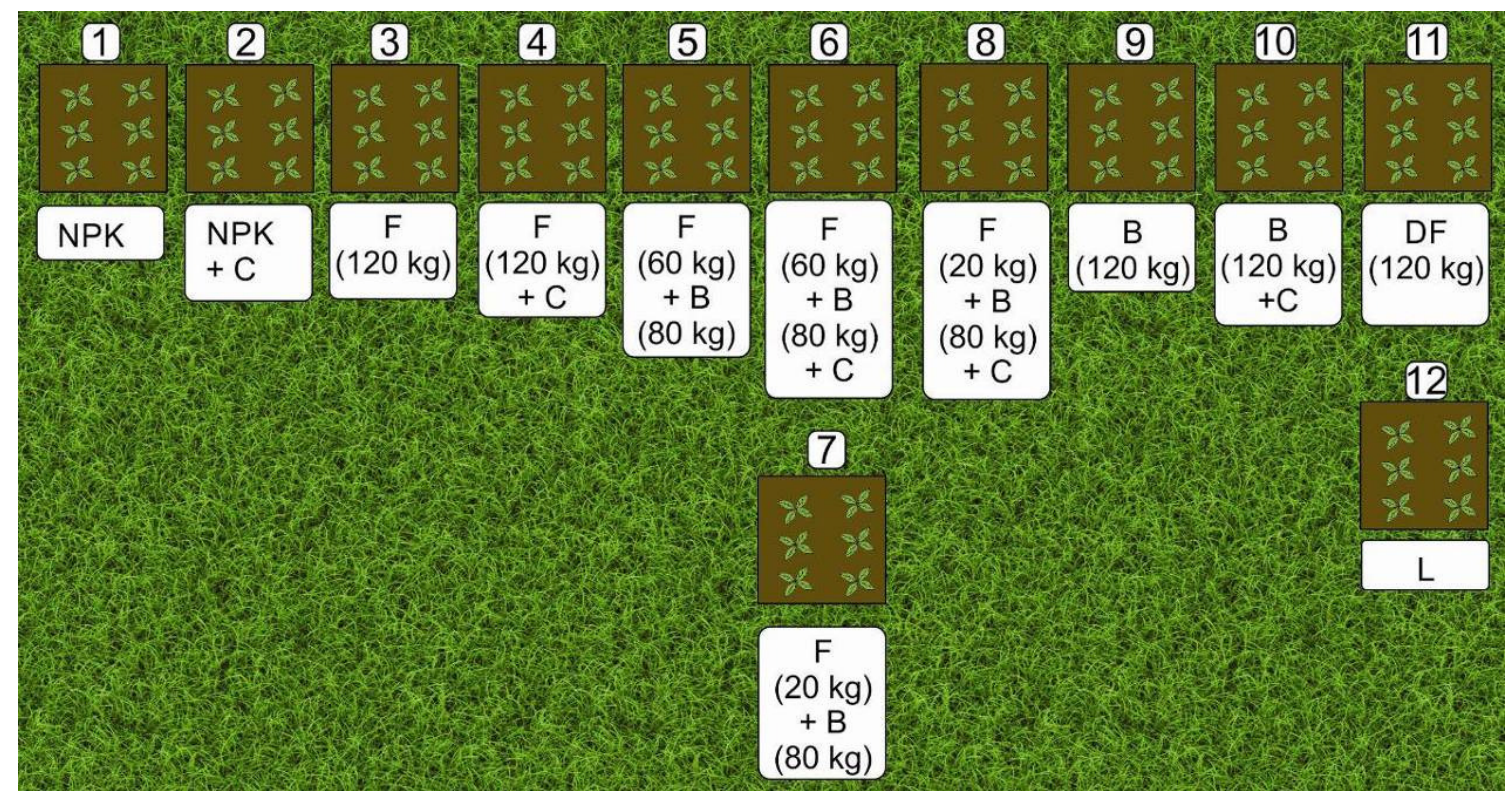

Figura 1.3- Esquema com os doze canteiros e suas respectivas misturas (Onde: $\mathrm{C}=$ Calagem, $\mathrm{F}=$ Fosforito, $\mathrm{B}=$ Basalto, DF = Dolomito Fosfatado, $\mathrm{L}=$ Latossolo $)$.

Após a aplicação dos insumos, as misturas ficaram em repouso durante 15 dias, logo em seguida, o solo foi revolvido nos primeiros $20 \mathrm{~cm}$, com o intuito de acelerar os processos de alteração e liberação de nutrientes (Figura 1.4). A exceção é relacionada ao NPK que foi colocado de forma direta durante a semeadura.

A quantidade de pó de calcário utilizado no processo de calagem $(30 \% \mathrm{CaO}, 18 \% \mathrm{MgO}$, $100 \%$ RN e 100\% PRNT), foi baseado em recomendações de Oliveira et al. (2004) para o plantio do feijoeiro, que indicam a necessidade de correção do $\mathrm{pH}$ para valores entre 5,8 e 6,2 e saturação por bases para 50\%. Com isso, utilizando o cálculo de necessidade de calagem por meio da saturação por bases, chegou-se a necessidade de aplicação de 1,84 ton.ha $^{-1}$ de pó de calcário.

Segundo Quintela \& Ferreira (2003) pesquisas realizadas com o plantio de feijão evidenciaram aumentos de até $54 \%$ na produtividade do feijoeiro decorrentes da calagem e de uma dose econômica de adubação no plantio, de aproximadamente $400 \mathrm{~kg} \mathrm{ha}^{-1}$ do formulado 4:30:16. No presente experimento, a tonelagem por hectare foi mantida, entretanto, utilizou-se uma concentração semelhante de NPK de formulação 4:30:10. 
Durante o plantio, seguiram-se as recomendações de Quintela \& Ferreira (2003) com espaçamentos de 0,40 a 0,60 m entre fileiras e com 10 a 15 plantas por metro quadrado.
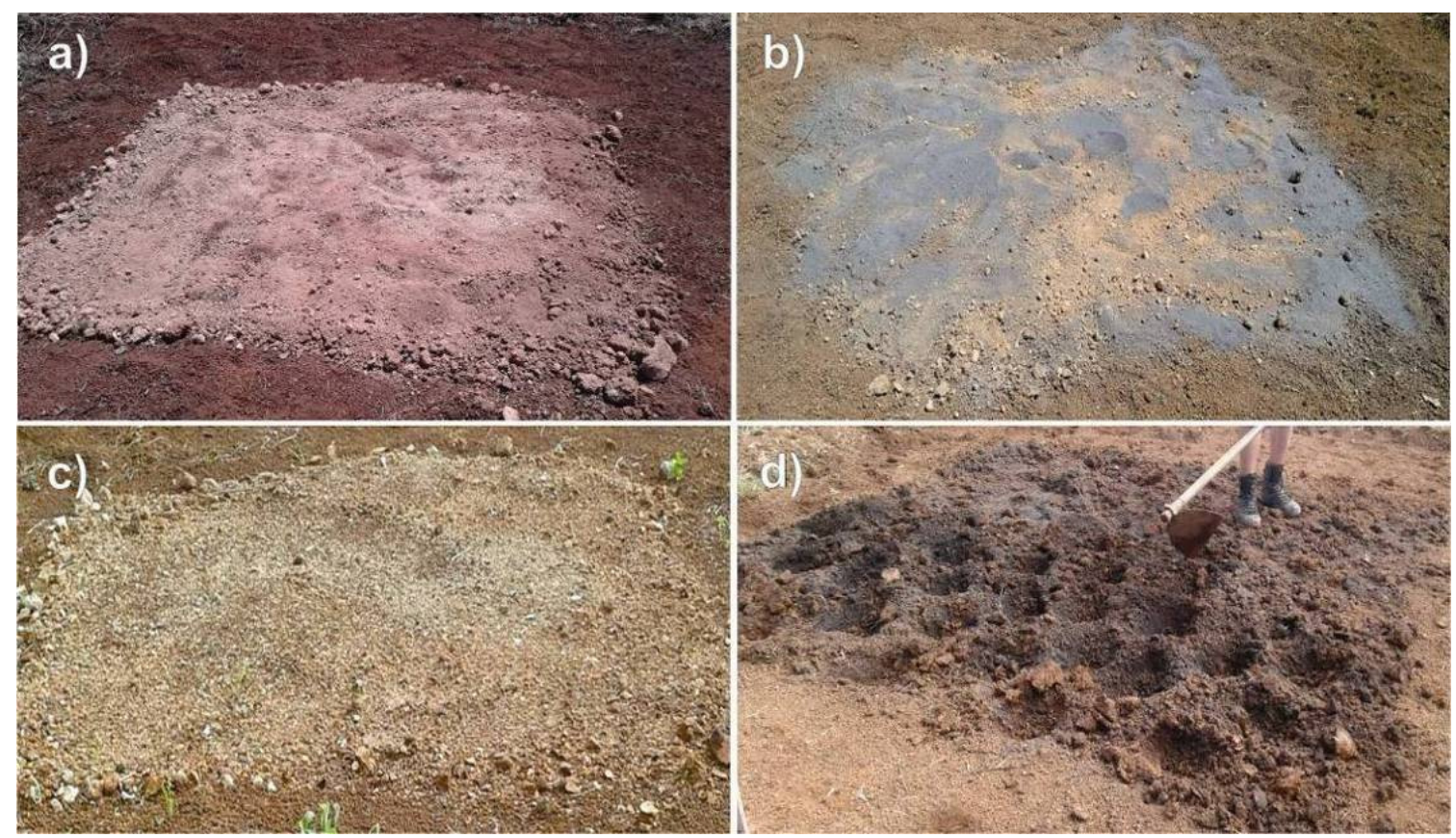

Figura 1.4 - Compilação de fotografias evidenciando a metodologia de preparação dos canteiros. a) Aplicação de fosforito puro de forma direta após aragem preliminar da terra. b) Mistura de pós de basalto e fosforito. c) Aspecto geral de um canteiro após repouso de 15 dias. d) Mistura do material com posterior semeadura nos primeiros $10 \mathrm{~cm}$.

Em seguida, iniciou-se o plantio do feijão vagem (Phaseolus vulgaris) de forma manual. Esta cultura foi escolhida pelo rápido ciclo de desenvolvimento, sendo que em um período de 60 dias já é possível analisar importantes resultados agronômicos. Deste modo, em um curto espaço de tempo é possível realizar várias colheitas e chegar a resultados mais contundentes.

É importante frisar que a semente utilizada não passou por nenhum tratamento específico, sendo que os resultados obtidos não poderão ser comparados com outros dados agronômicos, mas somente de forma comparativa entre cada parcela plantada no presente experimento.

\subsubsection{Estudos Petrográficos}

Com o intuito de compreender a mineralogia e, consequentemente, a composição dos elementos contidos nas rochas, realizou-se um sucinto estudo petrográfico constituído da análise de lâminas petrográfica de fosforito e de basalto.

O modo de preparo da lâmina delgada é realizada por um processo de corte da amostra a uma espessura aproximada de $2 \mathrm{~mm}$, que é colada numa lâmina de vidro, posteriormente, é realizado o rebaixamento e polimento com pó de alumina até a espessura de 0,03mm. A descrição mineralógica e textural foi feita com auxílio de microscópio binocular de luz transmitida. 


\subsubsection{Difratometria de Raios-X}

O uso de aparelho de difratometria de raios-X permite medir a intensidade das radiações difratadas pelos minerais, caracterizando suas dimensões cristalinas. Assim sendo, esse aparelho é capaz de medir a intensidade dos raios a diversos ângulos $2 \theta$.

$\mathrm{Na}$ identificação de um mineral, primeiramente, é necessário medir as distâncias interplanares (d) e as intensidades relativas no difratograma. Para isso, existem tabelas que permitem de forma direta, por meio da equação de Bragg (Equação 1.1), transformar o $2 \theta$ em valores de d. Posteriormente, é necessário comparar os espaçamentos interplanares e as intensidades relativas com minerais padrões certificados.

Equação 1.1 - Equação de Bragg utilizada na difratometria de raios-X.

\begin{tabular}{|c|}
\hline $\mathrm{n} \lambda=2 \mathrm{~d} \sin \theta$ \\
\hline$\lambda=$ comprimento de onda dos raios-X. \\
$\boldsymbol{\theta}=$ ângulo de incidência dos raios-X. \\
$\mathbf{d}=$ distância interplanar do cristal. \\
$\mathbf{n}=$ ordem de difração $(1,2 \ldots \mathrm{n})$. \\
\hline
\end{tabular}

No presente estudo todas as amostras foram analisadas em duas etapas: análise da rocha total e análise da fração argila.

$\mathrm{Na}$ análise da rocha total, as amostras são desagregadas mecanicamente com martelo em um gral de ágata. O pó resultante é compactado a seco em uma lâmina de vidro que possui uma cavidade retangular, e é levada para análise em um difratômetro de Raios-X modelo Rigaku Ultima IV (Figura 1.5), operando com tubo de cobre e filtro de níquel, sob voltagem de $35 \mathrm{kv}$ e $15 \mathrm{~mA}$, à velocidade de varredura de 5\% min, em um ângulo de leitura de 2 a $80^{\circ}$.

Para a identificação dos argilominerais (fração argila), adota-se o procedimento de rotina do Laboratório de Raios-X da Universidade de Brasília que consiste em realizar a dispersão da amostra pulverizada e posterior centrifugação em centrífuga ThermoScientific IEC CL31R Multispeed por 7 minutos a $750 \mathrm{rpm}$ (Figura 1.5). O sobrenadante é separado e novamente centrifugado, desta vez por 30 minutos a $3000 \mathrm{rpm}$. Ao final do processo espalha-se o material do fundo sobre uma lâmina de vidro utilizando-se a técnica do "esfregaço" a fim de orientar o material, seco ao ar e posteriormente analisado por DRX de 2 a $40^{\circ}$ com velocidade de $5^{\circ} / \mathrm{min}$, mantendo-se as demais condições de análise da rocha total. Tratamentos adicionais, como solvatação em etilenoglicol com duração de 12 horas e aquecimento a $490^{\circ} \mathrm{C}$ em mufla por 4h30min, são feitos para distinguir os argilominerais com reflexões semelhantes quando analisados na lâmina orientada. 

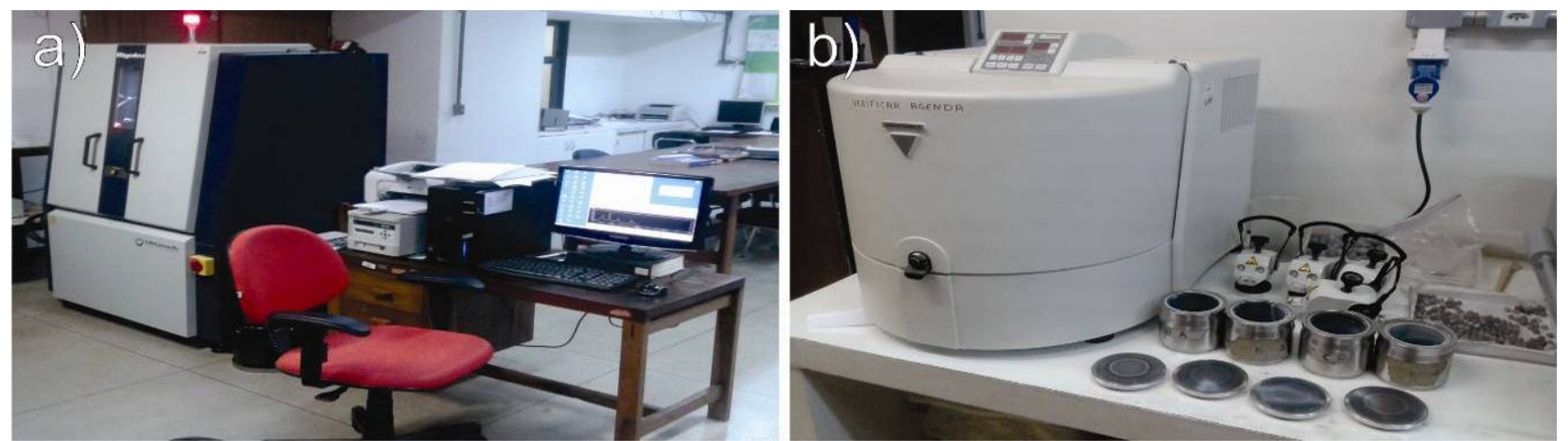

Figura 1.5 - Fotos mostrando equipamentos utilizados na difratometria de raios-X no laboratório da Universidade de Brasília (Instituto de Geociências). a) Fotografia do difratômetro de Raios-X Rigaku Ultima IV. b) Fotografia da centrífuga modelo ThermoScientific IEC CL31R Multispeed.

A interpretação dos difratogramas é feita pelo programa JADE 9.4 da MDI, que possui um banco de dados produzido pelo International Center for Diffraction Data-ICDD.

\subsubsection{Fluorescência de Raios-X}

A técnica analítica nuclear de fluorescência de raios-X (XRF) é usada para a determinação quali-quantitativa da composição química em vários tipos de amostras de interesse agropecuário, agroindustrial, geológico e ambiental.

Este método de rápida aplicação, não destrutivo e de baixo custo apresenta elevado potencial de aplicação em várias áreas, onde há necessidade de correlação entre os elementos essenciais e traços (Nascimento Filho 1999).

No presente estudo a técnica utilizada foi por meio do espectrômetro ZSX Primus II de fluorescência de raios-X por dispersão por comprimento de onda (WD-XRF) (Figura 1.6). Analisou-se um total de 22 óxidos e elementos, sendo eles: $\mathrm{SiO}_{2}, \mathrm{Al}_{2} \mathrm{O}_{3}, \mathrm{MgO}, \mathrm{Fe}_{2} \mathrm{O}_{3}, \mathrm{CaO}$, $\mathrm{Na}_{2} \mathrm{O}, \mathrm{K}_{2} \mathrm{O}, \mathrm{TiO}_{2}, \mathrm{P}_{2} \mathrm{O}_{5}, \mathrm{MnO}, \mathrm{SO}_{3}, \mathrm{Sr}, \mathrm{Rb}, \mathrm{Ni}, \mathrm{Cu}, \mathrm{Zn}, \mathrm{Zr}, \mathrm{Cr}, \mathrm{V}, \mathrm{Co}, \mathrm{Nb}, \mathrm{Pb}$.

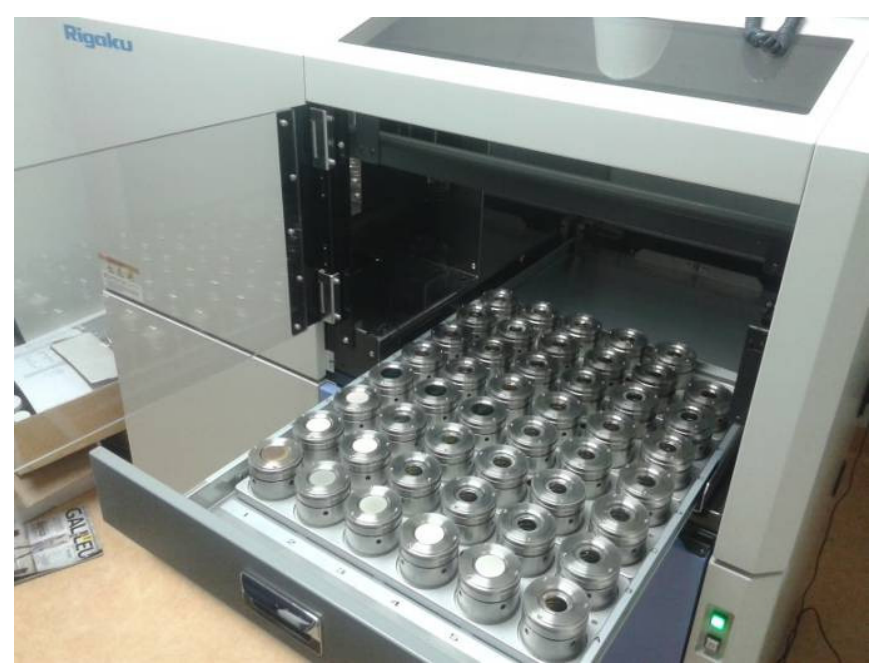

Figura 1.6 - Espectrômetro de dispersão por comprimento de onda ZSX Primus II. Notar a presença das pastilhas de pó prensado em pequenos cilindros metálicos. 
A fluorescência de raios-X é baseada na excitação da amostra por raios-X nos seus respectivos níveis eletrônicos mais internos e durante um subsequente rearranjo eletrônico o átomo volta ao estado fundamental emitindo radiação fluorescente (ou secundária). A intensidade dessa radiação permite determinar a concentração dos elementos por meio de curvas de calibração. Apesar disso, a intensidade da radiação não é diretamente proporcional a sua concentração, pois é afetada por outros elementos presentes na amostra. Essa interferência é denominada efeito matriz tendo de ser corrigido de forma química ou matemática (Potts 1992, Toledo 1998). Assim, de modo resumido, a análise por fluorescência de raios-X consiste de três fases: excitação dos elementos que constituem a amostra, dispersão dos raios-X característicos emitidos pela amostra e detecção desses raios-X (Nascimento Filho 1999).

No presente estudo, realizou-se a metodologia da pastilha de pó prensada onde a amostra deve ser previamente moída até apresentar granulometria aproximada de $75 \mu \mathrm{m}$.

Depois disso, nove gramas desse material são agitados junto com cera aglutinante (Wax powder 1,5g) no misturador Mixer/Mill 8000 por 3 minutos. Esse pó é prensado durante 1 minuto numa pressão de 15 toneladas. Por fim, é levado ao espectrômetro para o procedimento de análise.

\subsubsection{Medição de pH em Água e KCl}

A análise do pH do solo é de fundamental importância para entender a disponibilidade de nutrientes para as plantas. Neste contexto, cerca de $70 \%$ das cargas que compõem a superfície do Latossolo são variáveis, ou seja, são influenciadas diretamente pela a variação do pH. Os outros $30 \%$ estão relacionadas com cargas do tipo permanente, as quais estão ligadas as substituições isomórficas (Ribeiro et al. 2011, Machado et al. 2013).

Foram realizadas mensalmente análises de $\mathrm{pH}$ em $\mathrm{H}_{2} \mathrm{O}$ e em $\mathrm{KCl}$ com o objetivo de compreender o equilíbrio iônico nas misturas de pó de rocha. No procedimento adotado foram usadas $1 \mathrm{~g}$ de amostra de solo misturado em $5 \mathrm{ml}$ de água destilada ou em solução de 0,0746 g/ml de KCl. Essas soluções foram levadas ao agitador durante 30 minutos com posterior medição no equipamento multiparâmetro portátil.

\subsubsection{Elementos Disponíveis (Análise de Fertilidade do Solo)}

Os dados obtidos nesta etapa visam analisar a fertilidade do solo e a disponibilidade de nutrientes dos pós de rocha disponíveis para as plantas. Deste modo, foram enviadas amostras para o laboratório da empresa "Soloquímica Análises de Solos LTDA".

A análise constituiu essencialmente da medição dos elementos presentes no complexo sortivo $\left(\mathrm{Ca}^{2+}, \mathrm{Mg}^{2+} \mathrm{K}^{+}, \mathrm{Na}^{+}, \mathrm{H}^{+}\right.$e $\left.\mathrm{Al}^{3+}\right)$, fósforo total e $\mathrm{pH}$ em água. Este tipo de análise é comumente denominada de análise de fertilidade do solo e segue a metodologia da EMBRAPA. 
Utilizaram-se dois extratores de fósforo visto que o Mehlich-1 amplamente difundido no Brasil, normalmente, superestima valores de $\mathrm{P}$ disponíveis em solos com uso de fosfato natural. Já o uso do extrator de resina trocadora de íons ameniza esses efeitos embora sua aplicação em larga escala seja bem mais complexa (Rolim et al. 2008).

\subsubsection{Testes Agronômicos}

Os testes agronômicos basearam-se em três etapas principais, o método de cálculo de área foliar, peso de massa verde e peso da produção.

Ocorreram três plantios nos experimentos, entretanto devido a problemas de pragas e vandalismo, somente o cálculo de área foliar teve suas medidas calculadas em cada colheita. $\mathrm{O}$ cálculo da massa verde e do peso da produção apresentou apenas uma etapa de medida ao final da terceira colheita.

O peso da massa verde (MV) é o cálculo da massa da porção aérea da planta (caule, folhas, ramos e vagens). Já o peso da produção envolve o peso das vagens (PV) e o peso dos grãos de feijão (PG).

O método da área foliar permite compreender a relação existente entre o crescimento das plantas e o ambiente onde elas estão situadas (Jesus Júnior et al. 2001).

Segundo Toebe et al. 2012, para o cálculo do feijão-vagem (Phaseolus vulgaris L.) é suficiente a medição do comprimento e da largura do folíolo central. Posteriormente, usa-se a Equação 1.2, que apresenta coeficiente de determinação satisfatório de 0,9857.

Equação 1.2 - Cálculo de área foliar idealizado por Toebe et al. (2012) para o feijão-vagem (Phaseolus vulgaris L.).

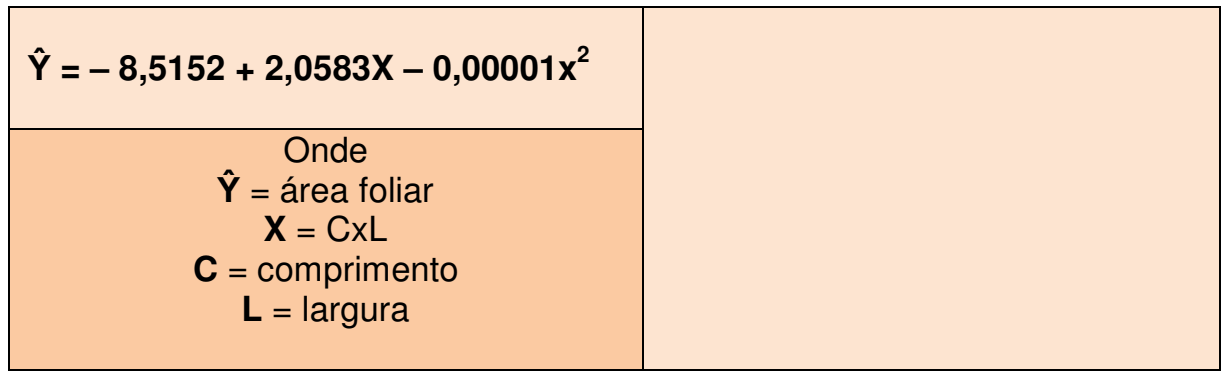

Neste projeto, o cálculo da área foliar foi realizado no primeiro e segundo mês do plantio, podendo se ter uma clara ideia das diferenças de desenvolvimento dos canteiros. Em todos os métodos de cálculo da resposta agronômica foram utilizadas um número reduzido de cinco plantas, deste modo, o resultado de produção é mais precisamente relacionado ao espécime individual do que a produção por hectare. Ainda, os resultados são válidos somente em uma comparação interna, não tendo boa correlação com a produtividade comercial, visto que não se empregou pesticidas e nem sementes selecionadas. 


\section{CAPÍTULO 2 \\ FUNDAMENTAÇÃO TEÓRICA}

Para compreender melhor o uso da rochagem, é necessário entender quais são os macronutrientes e micronutrientes essenciais para as plantas (Tabela 2.1). Os macronutrientes são os mais importantes para o bom desenvolvimento das plantas e são consumidos em grandes quantidades. Já os micronutrientes ou microelementos são elementos-chave para o crescimento das plantas embora não sejam consumidos em grande escala (Lapido-Loureiro \& Nascimento 2009).

Segundo Malavolta (2008) o trabalho realizado por Arnon \& Stout (1939) já descrevia e classificava os 19 elementos essenciais para as plantas: (I) critério direto - o elemento faz parte de um composto ou de uma reação crucial do metabolismo (II) critério indireto - abrange as seguintes circunstâncias: (a) na falta do elemento a planta morre antes de completar o seu ciclo, (b) o elemento não é substituível por nenhum outro; (III) o efeito do elemento não deve estar associado com o melhoramento de condições físicas, químicas ou biológicas desfavoráveis do meio. Como exemplo, têm-se o sódio $(\mathrm{Na})$ e o silício $(\mathrm{Si})$ os quais sem eles a planta vive; entretanto, em dadas condições, podem melhorar o crescimento e aumentar a produção.

Tabela 2.1 - Macro e micronutrientes essenciais para o desenvolvimento da planta (Malavolta 1980, 1999 e 2008).

\begin{tabular}{|c|l|l|}
\hline \multirow{2}{*}{ Macronutrientes } & Metais & $\mathrm{K}, \mathrm{Ca}, \mathrm{Mg}$ \\
\cline { 2 - 3 } & Não metais & $\mathrm{C}, \mathrm{H}, \mathrm{O}, \mathrm{N}, \mathrm{P}, \mathrm{S}$ \\
\hline \multirow{2}{*}{ Micronutrientes } & Metais & $\mathrm{Fe}, \mathrm{Mn}, \mathrm{Zn}, \mathrm{Cu}, \mathrm{Mo}, \mathrm{Co}, \mathrm{Ni}$ \\
\cline { 2 - 3 } & Não metais & $\mathrm{B}, \mathrm{Cl}, \mathrm{Se}$ \\
\hline
\end{tabular}

Vale salientar que os micronutrientes, embora aplicados em gramas/hectare, são fundamentais na obtenção de boa produtividade e qualidade. Sua aplicação é delicada porque o intervalo entre as concentrações ótima e tóxica no solo é, em regra, bastante restrito (LapidoLoureiro \& Nascimento 2009).

No Brasil e no mundo, diversos experimentos com o uso de rochagem já foram desenvolvidos, destacando-se de forma geral as rochas com seus respectivos nutrientes sintetizados por Levinson (1974) (Tabela 2.2). 
Tabela 2.2 - Principais tipos de rochas utilizadas no processo de rochagem e os nutrientes por elas disponibilizados (Levinson, 1974 In: Luz et al. 2010).

\begin{tabular}{|c|c|c|}
\hline Função & Tipo de Material & Nutrientes \\
\hline \multirow{4}{*}{$\begin{array}{c}\text { Calagem } \\
\text { e } \\
\text { nutrição } \\
\text { (remine- } \\
\text { ralização) }\end{array}$} & Calcários. & $\mathrm{Ca}$ \\
\hline & Calcários dolomíticos & $\mathrm{Ca}-\mathrm{Mo}$ \\
\hline & $\begin{array}{c}\text { Carbonatitos (mineralogia e geoquímica muito } \\
\text { variáveis). }\end{array}$ & $\mathrm{Ca}-\mathrm{Mg}-\mathrm{K}$, etc \\
\hline & Gesso $\left(\mathrm{CaSO}_{4}\right)$ natural e industrial. & $\mathrm{Ca}, \mathrm{S}$ \\
\hline \multirow{7}{*}{$\begin{array}{c}\text { Reminera } \\
\text { lização e } \\
\text { condicio- } \\
\text { namento } \\
\text { do Solo }\end{array}$} & Gessos natural e industrial. & $\mathrm{S}, \mathrm{Ca}$ \\
\hline & Rochas Fosfáticas. & $\mathrm{P}, \mathrm{Ca}$ \\
\hline & Carbonatitos. & $\mathrm{Ca}, \mathrm{Mg}, \mathrm{K}$, etc \\
\hline & $\begin{array}{l}\text { Rochas silicáticas vulcânicas: basalto, ugandito, } \\
\text { fonolitos, traquitos, etc. }\end{array}$ & $\mathrm{Mg}, \mathrm{Ca}, \mathrm{Si}, \mathrm{Fe}$ etc \\
\hline & $\begin{array}{c}\text { Rochas silicáticas granulares: granitos, sienitos, } \\
\text { nefelina sienitos, arenitos, etc. }\end{array}$ & $\begin{array}{l}\text { Macro e micro } \\
\text { nutrientes }\end{array}$ \\
\hline & $\begin{array}{l}\text { Minerais: feldspatos, argilas, piroxênios, anfibólios, } \\
\text { vermiculita, biotita, zeólitas e outros. }\end{array}$ & Variados \\
\hline & $\begin{array}{l}\text { Rejeitos e resíduos de minas, de minerais não } \\
\text { metálicos e de pedreiras. }\end{array}$ & Variados \\
\hline
\end{tabular}

Como há um grande número de rochas com possível aplicação na agrogeologia, serão abordados dois grupos de silicatos: multi-nutricionais e mono-nutricional.

\subsection{Breve Histórico}

O uso de fertilizantes para a melhoria do solo começou em 900 A.C com a utilização de estrume, especialmente de cavalos, gado e ovinos. Na Grécia antiga, os produtos de esgoto da cidade eram usados para a fertilização dos olivais. Nessa época, também foram reconhecidas as qualidades do solo nos campos de batalhas onde foram relacionados aos corpos humanos em decomposição. O salitre ou nitrato de K foi mencionado por Teofrasto e Plínio como conveniente para adubar as plantas e isso é mencionado na Bíblia, no livro de Lucas (Barnett et al. 1983, Tisdale et al. 1990, Lapido-Loureiro \& Nascimento 2009).

No século XIX, com o crescimento populacional, o uso de estrume e de guano importado da América do Sul era insuficiente, deste modo o químico Justus Von Liebig idealizou que os agricultores aplicassem no solo as substâncias minerais que se encontram nos vegetais. Em 1840 ele elaborou o fosfato de cálcio concentrado, porém não foi absorvido adequadamente pelas plantas (Barnett et al. 1983; Tisdale et al. 1990; Lapido-Loureiro \& Nascimento 2009). 
Outros inventores nessa mesma época descobriram fosfatos artificiais dissolvendo coprólitos em ácido sulfúrico. Ainda a escória rica em fósforo obtida no preparo de aço foi usada na fertilização. Em 1914 já eram conhecidos os usos dos superfosfatos bem como se intensificou a utilização de nitratos sintéticos (Barnett et al. 1983).

Mais especificamente, o uso de rochas na fertilização é conhecido desde a Grécia antiga. Plínio (62-113 d.C.) afirmava que o calcário deveria ser espalhado para formar uma fina camada sob o terreno e que um tratamento era "suficiente para vários anos, mas não para 50". Ainda Plínio sabia que a utilização de calcário queimado nos fornos era excelente para as oliveiras. Neste período Columelo reconhecia que o uso de cinzas ou calcário em solos poderia baixar a acidez (Tisdale et al. 1990, Lapido-Loureiro \& Nascimento 2009).

Outros relatos interessantes datam do século XVIII, quando Benjamin Franklin demonstrou o valor do gesso agrícola. Por meio de experimentos ele verificou o crescimento da pastagem na área onde o gesso havia sido aplicado (Lapido-Loureiro \& Nascimento 2009). No século XIX segundo Van Straaten (2006) destacam-se os trabalhos de Julius Hensel (1890, 1894) e Missoux (1853/54) sobre a utilização de rocha total como fonte de nutrientes. Hensel publicou, em 1894, um livro a que deu o peculiar título de "Pão das Rochas".

Mais recentemente, no Brasil, o uso de pós de rocha foi primeiramente sugerido na década de 1950 por Josué Guimarães e Vlademir Ilchenko. Mais tarde o professor Othon Leonardos, da Universidade de Brasília realizou importantes estudos relacionados ao tema (Martins \& Theodoro 2009). Finalmente, no século XXI os estudos focaram especialmente em fontes de $\mathrm{K}$ e P, sendo realizados importantes eventos como o I e II Congressos Brasileiros de Rochagem realizados respectivamente em 2009 e 2013.

\subsection{Histórico da Utilização das Rochas Silicáticas Multi-nutricionais}

Este grupo envolve rochas de composição mineralógica mais complexa, consequentemente, existe maior probabilidade de disponibilizar uma grande variedade de nutrientes. Como exemplo, podem-se destacar os basaltos, fonolitos, granitos, sienitos, entre outros. Devido ao presente estudo utilizar rochas basálticas, será dado maior enfoque a esse material.

Estudos com maior rigor acadêmico iniciam-se na década de 60 quando Keller et al. (1963) desenvolveram um importante trabalho sobre o intemperismo de minerais silicáticos, utilizando minerais pulverizados e analisando a dissolução de elementos em solução. Neste experimento, alguns minerais destacaram-se na liberação de determinados elementos como olivina $(\mathrm{Mg})$, enstatita $(\mathrm{Mg})$, nefelina $(\mathrm{Na}, \mathrm{Al})$, microclíneo $(\mathrm{K})$, biotita $(\mathrm{K}, \mathrm{Fe})$, diopsísio $(\mathrm{Si})$, e augita $(\mathrm{Ca})$. Observaram também que a solução enriquecida em $\mathrm{CO}_{2}$, semelhante às condições do 
ambiente natural, aumentaram significativamente a quantidade de elementos disponibilizados em relação à água destilada. Também, notou-se que o pH em água destilada, onde se misturaram o pó desses minerais variaram de 8,0 a 9,0 (exceto no quartzo que foi de 6,5).

Nas décadas de 70 e 80 onde já foram mencionados os trabalhos de Leonardos et al. (1976 e 1987), destaca-se também o estudo de Fyfe (1981), no qual alerta para uma maneira mais sustentável do uso da terra, sendo enfatizado a necessidade de um melhor controle químico das relações de transporte, mobilização e fixação dos elementos em novas rochas e minerais. Fyfe et al. (1983) relacionam ambientes tectônicos globais com a fertilidade do solo. Deste modo, afirmam que ambientes convergentes são mais férteis, pois estão ligados à renovação ocasionado pelo vulcanismo.

Nesta mesma época Chesworth (1982) faz importantes considerações sobre o balanço nutricional no solo, e sintetiza dizendo que a agricultura atual é insustentável pelo ponto de vista geoquímico, pois as colheitas anuais removem os nutrientes das plantas muito mais rapidamente que a reposição natural por intemperismo. Chesworth et al. (1983) utilizaram pós de rochas ígneas (ácidas e básicas) e determinaram que em solução, já nas primeiras horas eram disponibilizados importantes quantidades de potássio relacionado a partículas muito pequenas. Ainda, afirmam que rochas básicas são mais eficientes na disponibilidade de nutrientes que rochas graníticas. Chesworth et al. (1985) relacionam o aumento da umidade do solo com o uso de pós de rocha e a maior facilidade de disponibilidade de nutrientes da apatita em $\mathrm{pH}$ mais ácido.

Barak et al. (1983) utilizaram pós de basalto e tufos para aumentar a quantidade de ferro disponível. Importantes inferências estão relacionadas com a rápida disponibilização do ferro nas bordas dos minerais para as plantas, entretanto devido à oxidação e ou interação com carbonatos, a efetividade é diminuída, sendo necessária aplicação de maiores proporções do material.

Nos anos 90 Hinsinger et al. (1996) e Coroneos et al. (1996) realizaram estudos empíricos em condições controladas com pós de rochas graníticas. Nestes trabalhos sugere-se que uma porção minoritária do pó de rocha é dissolvida, sendo que a quantidade de K trocável não ultrapassa $5 \%$, além disso, o aumento do $\mathrm{pH}$ é pouco relevante se comparado com o uso da calagem convencional. Por fim, os autores afirmam que o uso deste material não é economicamente viável se comparado com a fertilização convencional e que elementos como $\mathrm{Ca}, \mathrm{Mg}$ e $\mathrm{Na}$ não foram encontrados na forma trocável devido a dissolução incongruente. Seguindo essa tendência, Bolland \& Baker (2000) enfatizam a ineficiência de rochas graníticas como fertilizantes, especialmente como fonte de potássio.

Gillman (1980) e Gillman et al. (2002), realizaram importantes estudos com rochas basálticas em clima tropical, e concluíram que os efeitos no aumento do pH só eram apreciáveis em alta tonelagem, entretanto se medido por meio de $\mathrm{KCl}$ notou-se uma importante redução em 
sua acidez. No que diz respeito aos elementos liberados, houve a presença de $\mathrm{Ca}, \mathrm{Mg}, \mathrm{K}$ e $\mathrm{Na}$, e com o aumento da taxa de aplicação ocorreu uma leve elevação da CTC. Entretanto, se comparado com a porcentagem inicial das rochas, uma pequena proporção de íons são liberados, sendo seus efeitos mais significativos a um prazo relativamente longo.

Mais recentemente, estudos feitos no Brasil apontam de forma positiva para o uso de pó de rocha, especialmente ligadas a rochas máficas. Melo et al. (2012) afirmam que doses de basalto atuam na neutralização da acidez potencial bem como aumenta teores de $\mathrm{Zn}, \mathrm{Fe}$ e $\mathrm{Cu}$ com o tempo de incubação, sendo o aumento relativamente baixo de $\mathrm{Ca}$ e $\mathrm{Mg}$. Resultados semelhantes são obtidos por Benuduzzi (2011) para basaltos e peridotitos. Já o trabalho de Souza (2014) com rochas vulcânicas máfico-ultramáficas indicam que o potencial econômico deste mineral é muito significativo, sendo equivalente ao uso do fertilizante comum quando aplicado uma dose de 6 t/ha, além de aumentar o pH e apresentar efeito residual.

Experimentos que focalizaram no aspecto mais social, também tiveram importantes conclusões. Almeida et al. (2007) em um experimentação com rochagem de fosforito e de basalto com duração superior a 10 anos abrangendo 400 famílias mostram que a combinação do aporte de pós de rochas com o manejo de biomassa em solos biologicamente ativos resultam em efeitos positivos sobre o desempenho produtivo de cultivos anuais já no curto prazo, a custos baixos, sem que para isso o ambiente seja degradado.

Entretanto, existem estudos realizados no Brasil com indicação negativa para o uso do pó de rocha como Erhart (2009) que afirma que de modo geral, os tratamentos com pó de basalto associado à calagem, independentemente da dose do pó de basalto aplicado, afetam pouco as características químicas do solo após um ano de avaliação do experimento, em relação ao tratamento com calagem associada à adubação com NPK. Ainda, Silva (2007) indica que o pH do solo não sofre mudanças significativas com a aplicação de basalto e que o emprego dessa técnica não aumentou o rendimento das plantas, todavia, houve incremento nos teores foliares de $\mathrm{N}, \mathrm{P}, \mathrm{Ca}, \mathrm{Mg}$ e $\mathrm{Zn}$.

Apesar de escassos, existem dados relacionados com a evolução mineralógica em ambientes tropicais. Lopes et al. (2014) afirmam que devido a um balanço de teores de íons em experimentos envolvendo pós de rochas basálticas houve a ocorrência de fenômenos de sorção com fases minerais neoformadas ou com ácidos orgânicos.

\subsection{Histórico da Utilização das Rochas Mono-nutricionais}

No presente tópico, serão focalizadas as rochas fosfatadas, especialmente as de origem sedimentar (ricas em francolita), visto que são agronomicamente mais efetivas que as rochas de origem ígnea (ricas em fluorapatita) (Léon et al. 1986, Gholizadeh et al. 2009). 
Estudos da aplicação de rochas fosfáticas iniciaram-se de forma incipiente na década de 1970. Podem ser citados os trabalhos sobre os fosfatos oriundos de Araxá e Olinda (Braga 1970, Goepfert 1975).

Nas décadas de 1980 e 1990 foram realizados diversos experimentos com resultados negativos e positivos sobre a eficiência agronômica da aplicação direta da rocha fosfatada. Esses dados contrastantes foram justificados por Van Straaten (2006) devido ao uso de rochas com mineralogias incompatíveis e aplicação em um meio ambiente inadequado.

Nesta mesma década, Chien \& Menon (1995) revisam os fatores que influenciam na solubilidade do fosfato no solo:

- Em pH mais baixos $(4,6)$ a solubilidade é maior que em pH elevados $(8)$.

- Aumento do teor de matéria orgânica forma complexos com cálcio, aumentando sua dissolução (Chien 1979).

- Adsorção do solo causa uma diminuição do fósforo (P) disponível ainda que seja responsável pela aceleração da decomposição da rocha (Smyth \& Sanchez 1982).

- Substituições isomórficas de fosfato por carbonato aumentam sua reatividade no solo.

- Baixo valor de CTC ocasiona uma menor disponibilidade de P para o sistema.

Deste modo, é possível concluir que em ambientes tropicais com pH ácido onde é comum a ocorrência de Latossolos e argissolos, existe uma disponibilização mais rápida de P. Na prática, o uso de cultivos perenes e mais tolerantes a acidez potencializariam o uso deste insumo (Goedert \& Lobato 1980, Chien et al. 1990).

Na última década Ndung'u et al. (2006) realizaram experimentos no Leste da África e concluíram que a aplicação de baixas quantidades de fosforitos trazem melhoras significativas para parâmetros como $\mathrm{pH}$ e $\mathrm{P}$ disponível, resultando em um melhor desenvolvimento das plantas. Entretanto, esses benefícios persistiram somente até a terceira estação de colheita, sendo necessárias outras aplicações. Ainda, Waigwa et al. (2003) e Husnain et. al. (2014) apresentam conclusões similares ao estudo anterior, enfatizando que a eficácia do uso do pó de rocha pode ser aumentada pela combinação com os materiais orgânicos comulmente encontrados em regiôes agrícolas. Também ressaltam que apesar de apresentarem uma interessante viabilidade econômica o uso desse insumo não é adotado pelos fazendeiros.

Outro aspecto importante do benefício do uso de rochas fosfatadas é encontrado na Flórida, onde a ocorrência de solos arenosos juntamente com o uso em larga escala de insumos solúveis acarreta a poluição de águas superficiais (Calvert 1975). Deste modo Chen et al. (2006) realizaram estudos satisfatórios com dolomitos fosfatados com o propósito de diminuir a excessiva lixiviação de P. Segundo estes autores 96,6\% do total de P adicionado na forma de fertilizante solúvel foi lixiviado nos dez primeiros testes de lixiviação. 


\subsection{Intemperismo e Pedogênese}

O intemperismo abrange diversos processos físicos, químicos e biológicos de hidrólise e alteração de rochas e minerais na superfície da Terra. Deste modo, os principais fatores que atuam no processo intempérico são clima, relevo, cobertura vegetal, circulação de água e consequentemente variações de Eh e pH, além da atividade biológica e do tempo (Santos 2014).

É simples de se imaginar que as rochas sedimentares por serem oriundas de processos de alteração apresentem uma evolução pequena, excetuando-se os processos de dissolução. Entretanto, as rochas ígneas e metamórficas apresentam estados de equilíbrios originais de alta pressão e temperatura, consequentemente, são muito mais instáveis na superfície (Pomerol et al. 2013).

Os minerais mais vulneráveis ao intemperismo apresentam uma sequência denominada série de Goldich. Para os minerais silicáticos de origem magmática esta série é semelhante à sequência inversa da série de cristalização de Bowen. Deste modo, os produtos dos processos de alteração geralmente serão mais enriquecidos em minerais mais resistentes como o quartzo, óxidos de ferro e alumínio e pobres em olivinas, piroxênios e anfibólios (Figura 2.1).

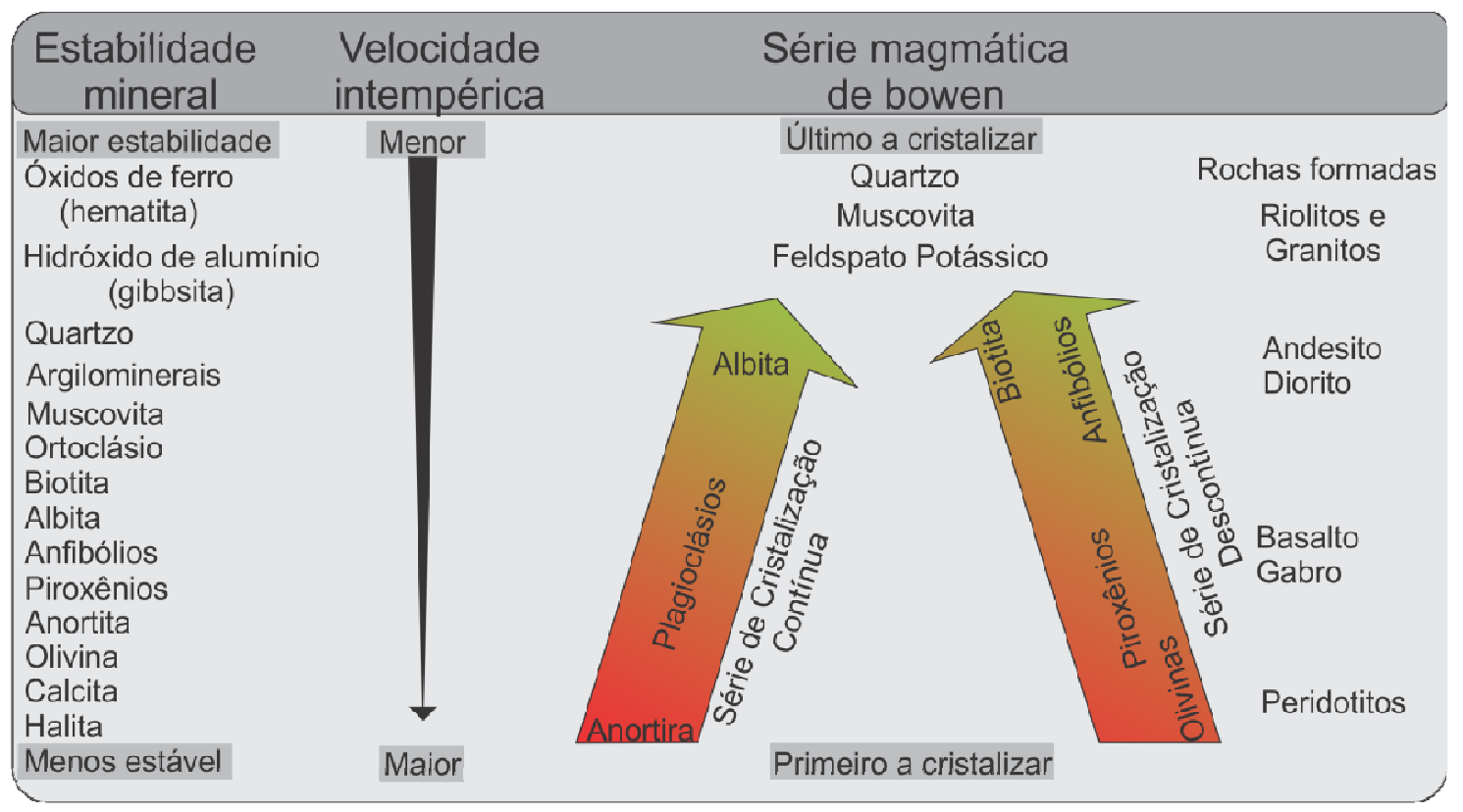

Figura 2.1 - Esquema evidenciando os minerais mais estáveis durante o processo de alteração. Notar a relação inversa entre a estabilidade mineral e a série magmática de Bowen (Teixeira et al. 2001).

De forma mais específica Hawkes \& Webb (1962) detalham o intemperismo dos minerais mais comuns formadores de rochas e a formação de minerais neoformados como ilita, vermiculita e óxidos e hidróxidos de ferro (Figura 2.2) (Santos 2014). 


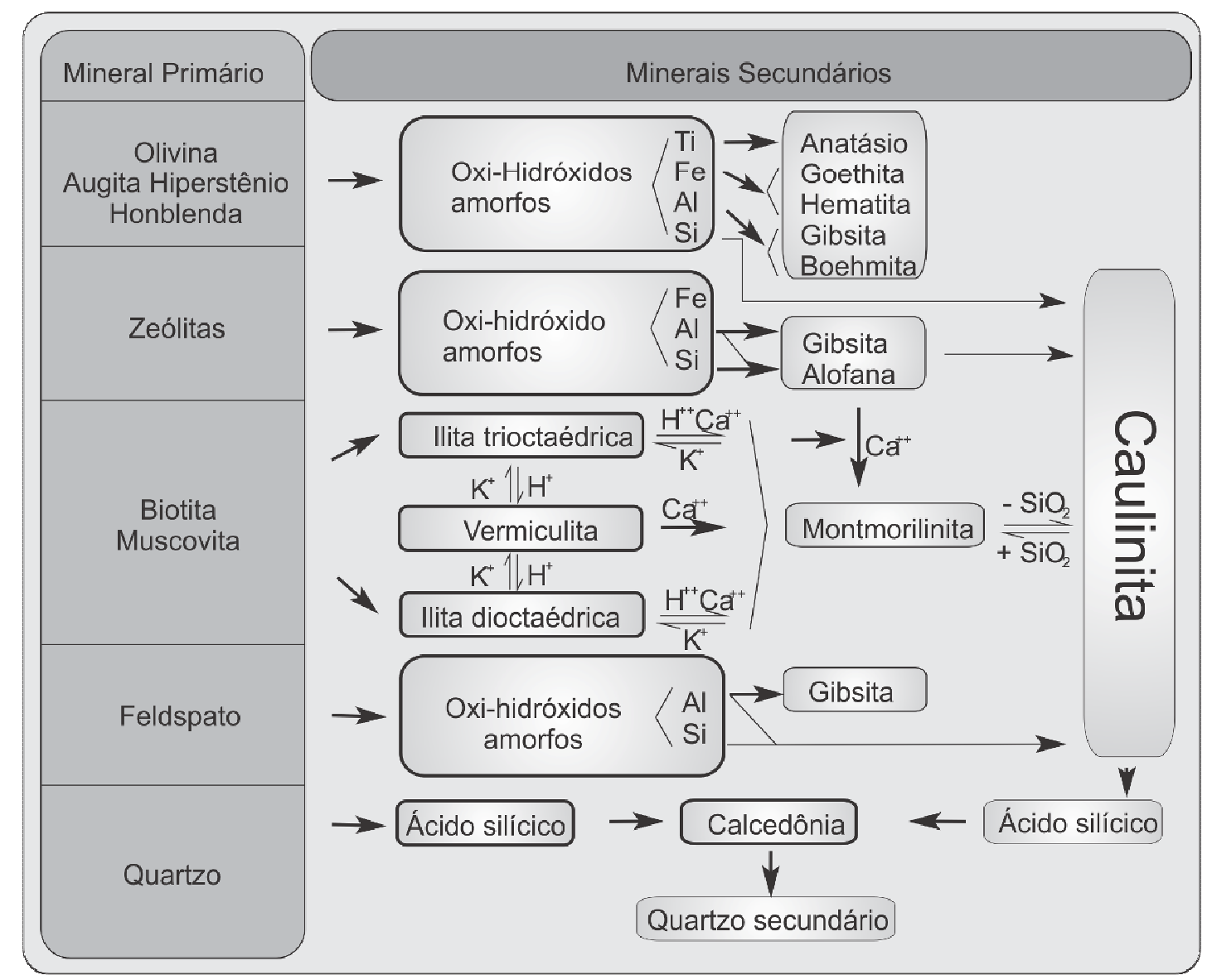

Figura 2.2 - Evolução mineralógica dos principais minerais constituintes das rochas com o avançar do processo intempérico (Hawkes \& Webb, 1962, extraído de Santos et al. 2014).

Seguindo esse pensamento, Chesworth (1977) em experimentos realizados com rochas vulcânicas, determinou que o basalto alcalino, inicialmente do tipo $(\mathrm{CaO}+\mathrm{MgO})$ e $\left(\mathrm{Na}_{2} \mathrm{O}+\mathrm{K}_{2} \mathrm{O}\right)$ se tornaram mais ricos no sistema $\left(\mathrm{SiO}_{2}+\mathrm{Al}_{2} \mathrm{O}_{3}+\mathrm{Fe}_{2} \mathrm{O}_{3}\right)$ (Figura 2.3) (Chesworth et al. 1989).

A associação destes processos intempéricos aos processos pedogenéticos dá origem aos solos. Os processos pedogenéticos que merecem destaque são segundo Santos (2014):

- Transformação: é dominante o processo de hidrólise com saída da sílica estrutural e mudança da fase mineral.

- Remoção: resultante da eliminação pelas águas de drenagem de elementos químicos imóveis.

- Translocação: migração de minerais na fração argila, argilominerais e matéria orgânica dos horizontes mais superficiais para os horizontes subsuperficiais.

- Adição: acúmulo de matéria orgânica, principalmente vegetal nos horizontes superficiais.

- Gleização: ocorre em ambiente redutor, em condições ácidas, que resulta na redução de ferro, manganês e outros metais. 


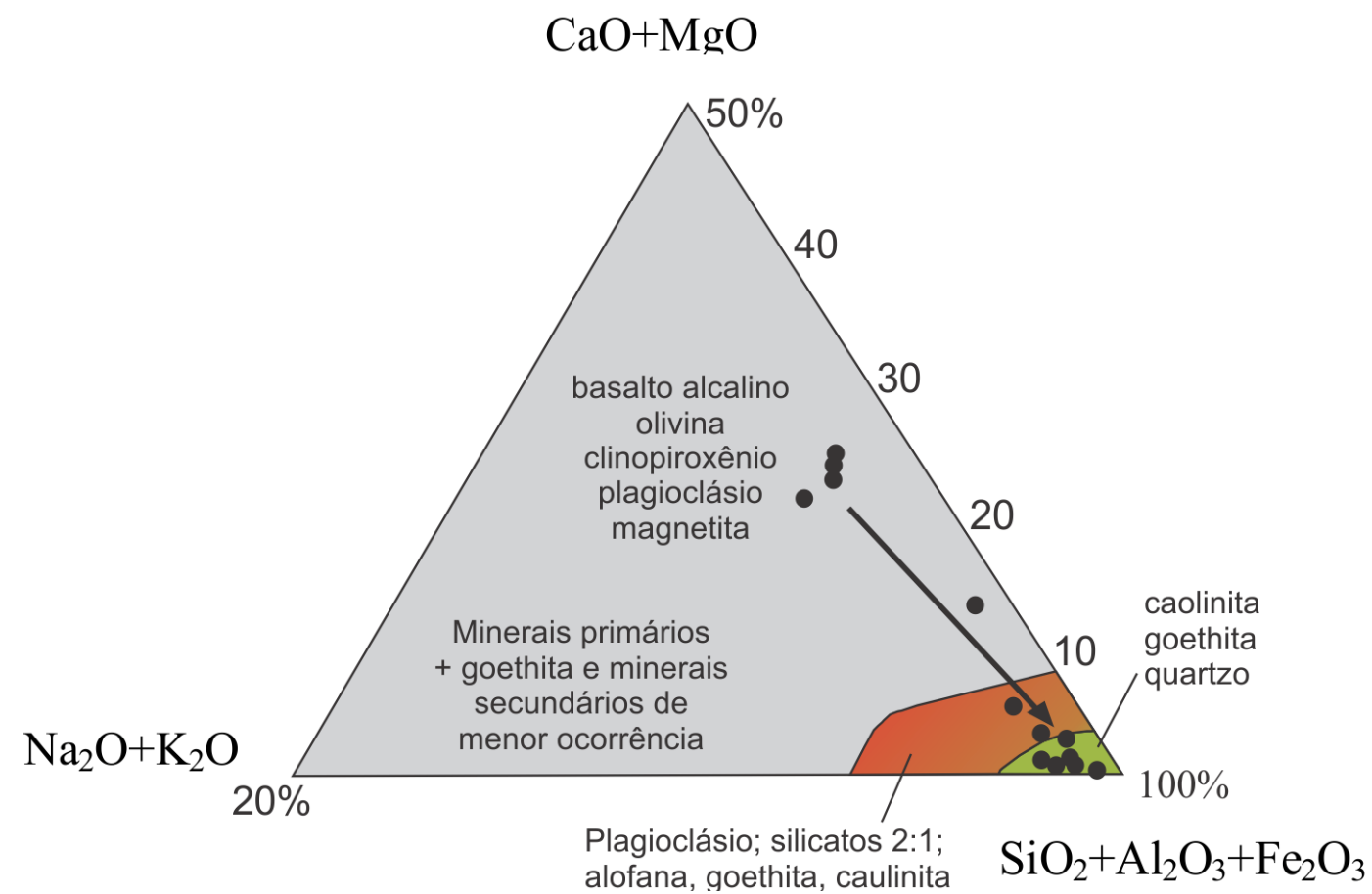

Figura 2.3 - Gráfico esquemático do experimento realizado por Chesworth (1977) para um ensaio com rochas vulcânicas de basalto alcalino. Notar o enriquecimento no sistema $\mathrm{SiO}_{2}+\mathrm{Al}_{2} \mathrm{O}_{3}+\mathrm{Fe}_{2} \mathrm{O}_{3}$ com o avanço do processo intempérico.

A origem dos solos se dá pela atuação conjunta de alguns destes processos, com o predomínio de um deles, além de outros processos específicos. Em ambientes tropicais e de relevo aplainado, com elevada precipitação e temperatura, os processos pedogenéticos ocorrem de forma mais intensa, especialmente os de transformação e remoção.

Assim sendo, no Brasil é muito frequente que os solos apresentem uma evolução muito avançada com atuação expressiva de processo de latolização (ferralitização ou laterização), resultando em intemperização intensa dos constituintes minerais primários, e mesmo secundários menos resistentes, e concentração relativa de argilominerais resistentes e, ou, óxidos e hidróxidos de ferro e alumínio (EMBRAPA 2006).

\subsection{Mecanismos de Dissolução das Rochas}

A eficiência agronômica da rochagem pode ser impossibilitada devido a baixas taxas de dissolução, deste modo, compreender as reações que liberam os nutrientes é de fundamental importância.

Diversos estudos que indicam a ineficiência do uso de pó de rocha desprezam que o desequilíbrio entre as soluções do solo e os minerais podem acelerar drasticamente os processos de liberação de nutrientes principalmente em solos empobrecidos, onde as soluções não estão em equilíbrio com os minerais primários frescos (Harley \& Gilkes 2000). Além disso, é fundamental entender as principais características dos minerais quando submetidos a processos intempéricos (Tabela 2.3). 
Tabela 2.3 - Características de minerais formadores de rochas quando submetidos a processos intempéricos (Compilação feita a partir de dados de Harley \& Gilkes, 2000).

\begin{tabular}{|l|l|}
\hline Mineral & Características quando submetida a processos intempéricos \\
\hline Quartzo & $\begin{array}{l}\text { Altamente resistente ao intemperismo. } \\
\text { Sílica é ligeiramente solúvel a valores de pH do solo ambiente. }\end{array}$ \\
\hline Feldspatos & $\begin{array}{l}\text { Apresenta restrita formação de mineral secundário devido sua } \\
\text { estrutura cristalina tetraédrica resistente }\end{array}$ \\
\hline Micas & $\begin{array}{l}\text { Estabilidade dependendo da intensidade de repulsão dos cátions } \\
\text { sobrepostos nas camadas. } \\
\text { Baixa repulsão (micas dioctaédricas) } \rightarrow \text { Estáveis (ex. muscovita) }\end{array}$ \\
$\begin{array}{l}\text { Alta repulsão (micas trioctaédricas) } \rightarrow \text { Instáveis (ex. biotita, } \\
\text { flogopita) }\end{array}$ \\
\hline $\begin{array}{l}\text { Minerais } \\
\text { ferromagnesianos }\end{array}$ & $\begin{array}{l}\text { Estrutura cristalina permite uma ampla e variada substituição de } \\
\text { elementos. } \\
\text { São susceptíveis ao intemperismo, liberando Fe } \\
\text { dissolução desses elementos é influenciada por processos do tipo } \\
\text { oxiredução. } \\
\text { Frequentemente ocorre a alteração para argilominerais, } \\
\text { especialmente a esmectita. }\end{array}$ \\
\hline
\end{tabular}

Para a melhor compreensão dos processos de dissolução dos minerais é necessário entender que existem duas forças opostas, a primeira é a forte ligação dos íons ao mineral contra os processos de hidratação (Banfield \& Hamers 1997, Harley \& Gilkes 2000).

Deste modo, os mecanismos de dissolução podem ser sintetizados (Harley \& Gilkes 2000):

1. Rápida troca entre os cátions da superfície e $\mathrm{H}^{+}, \mathrm{H}_{3} \mathrm{O}^{+}$e $\mathrm{H}_{2} \mathrm{O}$ (Casey \& Bunker 1990). Com o avanço desse processo a superfície do mineral torna-se menos reativa (Casey 2008).

2. Liberação de elementos na estrutura pela destruição de ligações metálicas. $O$ modo como ocorre à dissolução é mais controlado cristalograficamente que pelo produto corrosivo (Berner et al. 1980).

3. Os elementos liberados podem se precipitar na forma de compostos amorfos, argilas e óxidos. Além disso, a natureza da composição inicial presente no mineral parental ou dos minerais vizinhos, pode ser mais importante que o ambiente em sua macroescala (Sverdrup \& Warfvinge 1995).

\subsection{Fatores que Influenciam a Dissolução Mineral}

A relação entre os produtos e processos de alteração dos minerais com o solo, dependem de fatores como pH, reações de redox (no caso de minerais ferro magnesianos), soluções do solo e temperatura (Harley \& Gilkes 2000). 
$\mathrm{O}$ pH tem uma importante influência na liberação dos cátions da estrutura cristalina da rocha para o sistema, sendo mais rápida em ambientes básicos e ácidos, e lenta em porções neutras (Casey \& Bunker 1990). A tendência característica para a maioria dos minerais é similar ao dos feldspatos que é representado pela linha vermelha no gráfico da Figura 2.4.

Entretanto, ainda que a liberação dos elementos da rocha possa ser maior em $\mathrm{pH}$ ácidos ou básicos, a disponibilidade para as plantas pode ser menor. Ketterings et al. (2005) afirmam que elementos como $\mathrm{N}, \mathrm{P}, \mathrm{K}, \mathrm{S}, \mathrm{Ca}$ ficam disponíveis em $\mathrm{pH}$ neutro, já elementos como alumínio o qual é tóxico para a maioria das plantas se torna disponível em $\mathrm{pH}$ mais ácidos, resultando numa diminuição de produtividade (Figura 2.4).

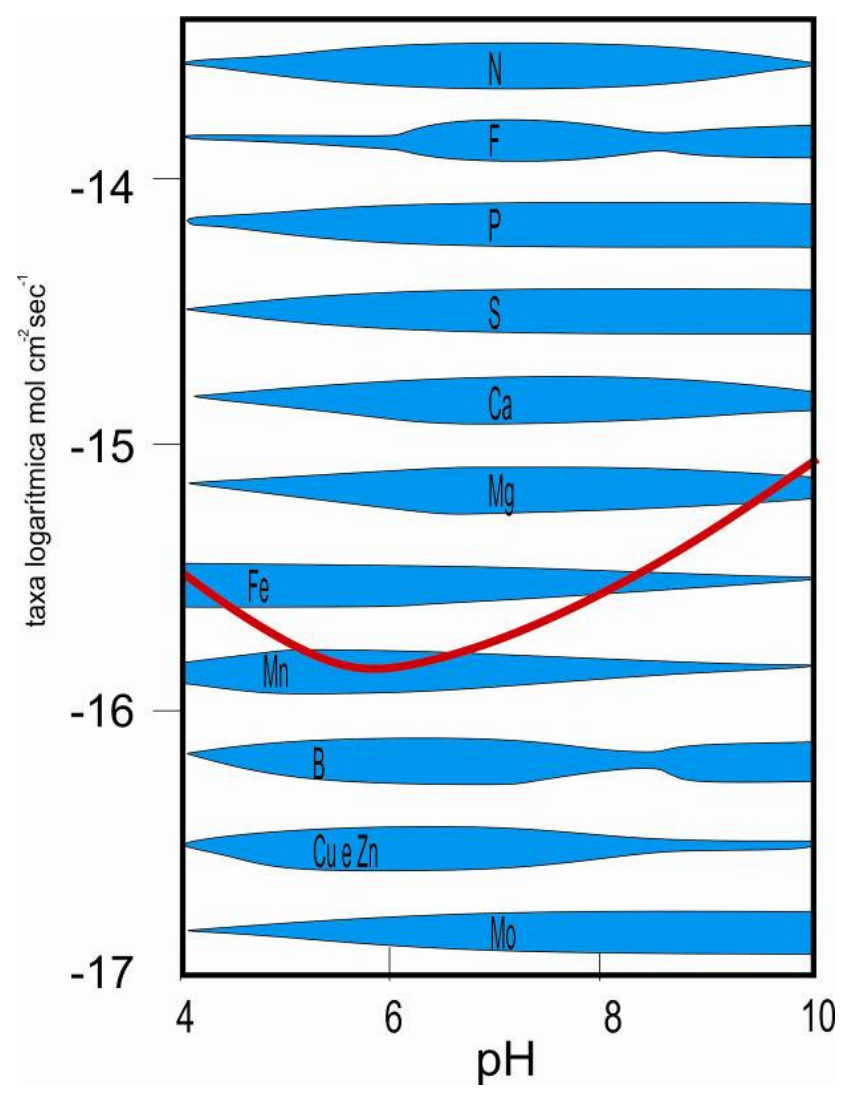

Figura 2.4 - A linha vermelha mostra a influencia do pH em relação a taxa de dissolução do feldspato (albita). Em azul, aparecem os elementos disponíveis para a planta relacionado de acordo com o $\mathrm{pH}$. Notar que em pH neutro há maior disponibilidade de nutrientes importantes para a planta $(\mathrm{F}, \mathrm{P}, \mathrm{S}, \mathrm{C}$, $\mathrm{Mg}$ ), entretanto ocorre uma menor taxa de dissolução das rochas. Modificado de Wollast \& Chou (1985), Harley \& Gilkes (2000) e Ketterings et al. (2005).

Em minerais ricos em $\mathrm{Fe}(\mathrm{II})$ e $\mathrm{Mn}(\mathrm{II})$ as reações de oxiredução são fundamentais no processo de rompimento das estruturas (Hering \& Stumm 1990). Além disso, a partir de rigorosa experimentação, White \& Blum (1994) afirmam que além da composição da solução presente no solo, outro fator que aumenta a taxa de dissolução mineral é o aumento da temperatura ambiente.

É de senso comum que quanto menor a granulometria do pó de rocha, os nutrientes serão liberados de forma mais rápida devido ao aumento exponencial da superfície de contato. Segundo Martins (2013) no estudo da rochagem é indicado a classificação da granulometria do pó de rocha em filler, pó, farelado e farelo fino. 
Neste contexto, há uma série de estudos que destacam a importância da granulometria mais fina no processo de rochagem para facilitar a disponibilização de nutrientes. Entretanto, é importante ressaltar que nas condições naturais do solo há fenômenos de agregação e adesão dos pós de rocha muito finos, consequentemente, há uma diminuição da superfície reativa exposta (Alfonso Filho et al. 2013).

Além disso, em um estudo realizado por Niwas et al. (1987) após um curto prazo de 6 semanas, pós de rocha de granulometria maior, apresentaram o mesmo nível de dissolução que dos materiais mais finos. Ainda, segundo Blum et al. (1989), o uso de pó de basalto menor que $200 \mu \mathrm{m}$ teve menor disponibilidade que pós que variaram de 200 a $2000 \mu \mathrm{m}$. Vale salientar que além da granulometria, a densidade dos defeitos cristalinos do mineral influencia amplamente no processo intempérico (Harley \& Gilkes 2000).

Por fim, processos da rizosfera e outros tipos de atividades biológicas podem acelerar a dissolução pela liberação de íons $\mathrm{H}^{+}$e complexação de compostos orgânicos que reagem com a superfície mineral (Harley \& Gilkes 2000). Darrah (1993) explica que embora exista uma ampla evidência nas mudanças físicas, químicas e biológicas da ação da rizosfera no solo, sua quantificação em relação à nutrição mineral é complexa.

Um dos aspectos mais importantes no âmbito da rizosfera é relacionado com a evolução mineralógica. Em um experimento com micas do tipo flogopita, a interação com a raiz, ocasiona uma intensa liberação de potássio intercamada com a formação de vermiculita em apenas poucos dias de cultivo (Hinsinger \& Jaillard 1993). 


\section{CAPÍTULO 3 \\ RESULTADOS E DISCUSSÕES}

\subsection{Descrição Pedológica}

Os dados pedológicos foram preliminarmente descritos por meio de uma trincheira de 60 $\mathrm{cm}$ de profundidade, onde foram observados quatro horizontes (A, AB, BA e Bw) e classificado como Latossolo Vermelho distrófico (Figura 3.1). A coloração varia de vermelho a marrom avermelhado, textura argilo arenosa com estrutura grumosa e granular (Tabela 3.1).

Segundo Ker (1998) a mineralogia deste tipo de solo é relativamente simples, sendo sua fração grossa (silte + areia) predominantemente composta por grãos de quartzo com menores proporções de feldspato potássico e muscovita quando originado a partir de rochas ácidas e de magnetita e ilmenita quando oriundo de rochas básicas. A fração argila possui diferentes proporções de caulinita, gibbsita, goethita e hematita. Menores proporções de vermiculita com hidroxi entre camadas, ilita, anatásio, rutilo, maghematita e mesmo haloisita, também são constatados com frequência em determinados Latossolos (principalmente aqueles menos desenvolvidos).

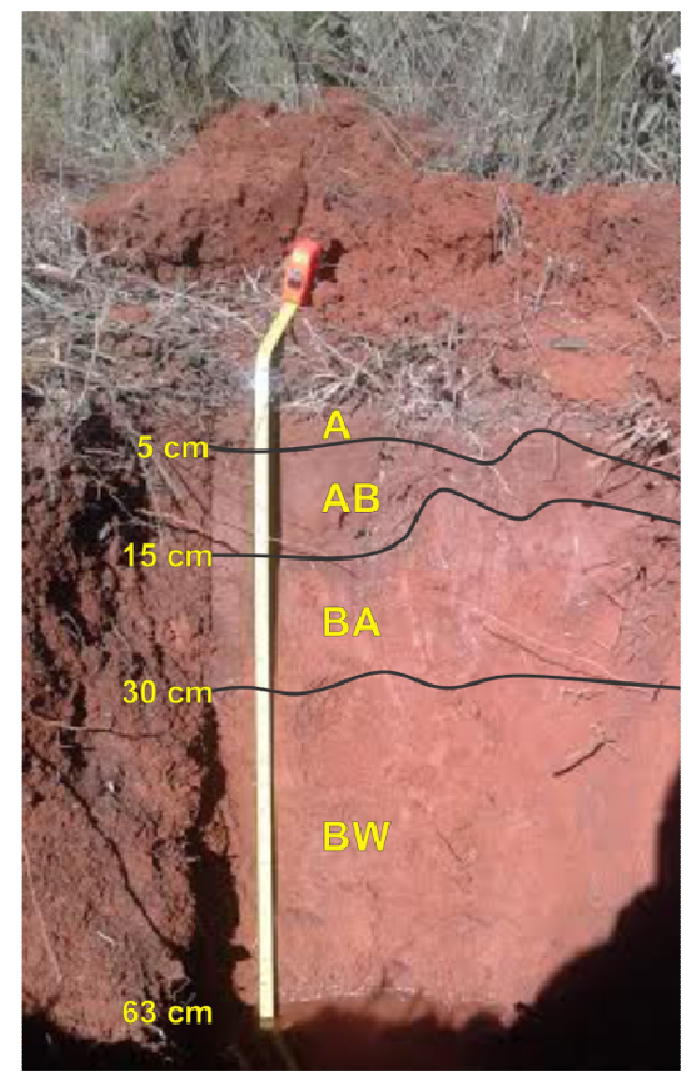

Figura 3.1 - Foto ilustrando os quatro horizontes do Latossolo Vermelho distrófico - A ( 0 a $5 \mathrm{~cm})$, AB (5 a $15 \mathrm{~cm}), \mathrm{BA}(15 \mathrm{a} 30 \mathrm{~cm})$ e Bw (maior que $30 \mathrm{~cm}$ ). O nível d'água raso é devido à elevação artifical 
ocasionada pela proximidade com a orla do Lago Paranoá.

Tabela 3. 1- Descrição dos horizontes presentes no Latossolo Vermelho utilizado no experimento.

\begin{tabular}{|c|c|c|c|c|}
\hline Horizonte & $\bar{A}$ & $\overline{\mathrm{AB}}$ & $\mathbf{B A}$ & BW \\
\hline Espessura & 0 a $5 \mathrm{~cm}$ & 5 a $15 \mathrm{~cm}$ & 15 a $30 \mathrm{~cm}$ & Maior que $30 \mathrm{~cm}$ \\
\hline Cor & $\begin{array}{c}\text { 10R 6/3 - marrom } \\
\text { avermelhado }\end{array}$ & $\begin{array}{c}\text { 10R 6/3 - marrom } \\
\text { avermelhado }\end{array}$ & $\begin{array}{l}\text { 10R 5/6 - } \\
\text { vermelho }\end{array}$ & $\begin{array}{l}\text { 10R 5/6 - } \\
\text { vermelho }\end{array}$ \\
\hline Textura & Argilo arenosa & Argilo arenosa & Argilo arenosa & Argilo arenosa \\
\hline Estrutura & $\begin{array}{l}\text { Comum grossa } \\
\text { granular }\end{array}$ & $\begin{array}{c}\text { Comum média } \\
\text { granular. Rara } \\
\text { grumosa }\end{array}$ & $\begin{array}{c}\text { Comum média } \\
\text { grumosa. Rara } \\
\text { granular }\end{array}$ & $\begin{array}{l}\text { Comum média } \\
\text { grumosa. Rara } \\
\text { granular. Presença } \\
\text { de plintita e leve } \\
\text { mosqueamento. }\end{array}$ \\
\hline $\begin{array}{c}\text { Consistência a } \\
\text { seco }\end{array}$ & Duro & $\begin{array}{c}\text { Moderadamente } \\
\text { duro }\end{array}$ & $\begin{array}{c}\text { Moderadamente } \\
\text { duro }\end{array}$ & $\begin{array}{l}\text { Moderadamente } \\
\text { duro }\end{array}$ \\
\hline $\begin{array}{c}\text { Consistência } \\
\text { úmida }\end{array}$ & Pouco friável & $\begin{array}{c}\text { Moderadamente } \\
\text { friável }\end{array}$ & Pouco friável & Pouco friável \\
\hline $\begin{array}{c}\text { Consistência } \\
\text { molhada }\end{array}$ & $\begin{array}{l}\text { Pouco pegajoso e } \\
\text { plástico }\end{array}$ & $\begin{array}{l}\text { Pouco pegajoso e } \\
\text { plástico }\end{array}$ & $\begin{array}{c}\text { Pouco pegajoso e } \\
\text { plástico }\end{array}$ & Pegajoso e plástico \\
\hline Transições & Abrupta irregular & Abrupta irregular & Abrupta planar & -- \\
\hline
\end{tabular}

No presente estudo, antes de qualquer tipo de plantio e aplicação de insumo, realizou-se difratometria de raios-X que indicou a presença de gibbsita, goethita, caulinita, quartzo, ilita, anatásio, hematita e rutilo (Figura 3.2).

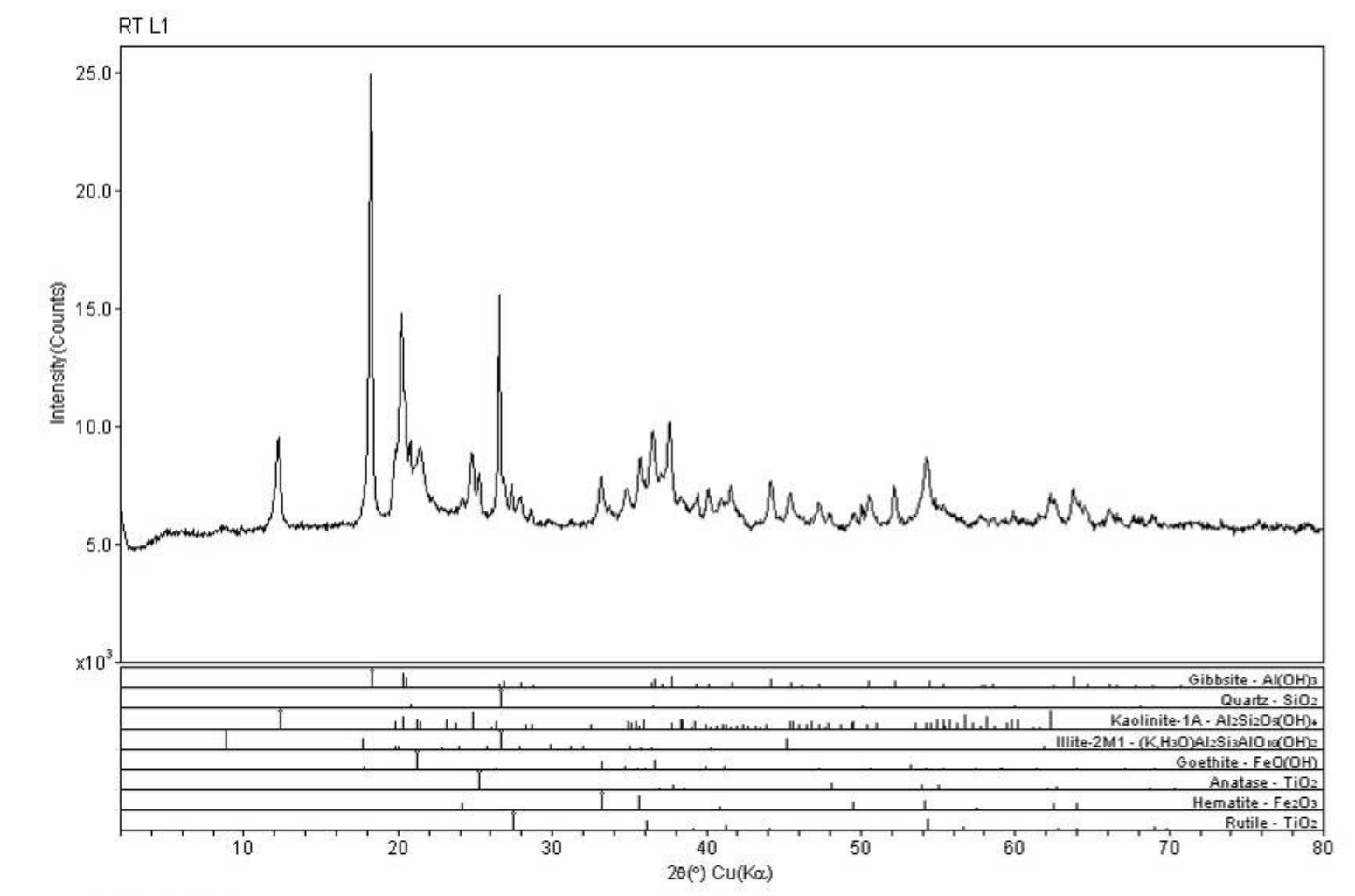

Campus Univ Darby Ribeiro

[RAOO-XIIG] Friday, June 26, 2015 11:583 MMOIJADE

Figura 3.2 - Difratometria de raios-X indicando mineralogia principal do Latossolo de goethita, gibbsita, hematita, caulinita e quartzo. Secundariamente ocorre ilita, anatásio, e rutilo.

A ocorrência da ilita pode estar relacionada com a origem do material parental, que neste caso, é representado por ardósias da Formação Ribeirão do Torto do Grupo Paranoá. Ainda nota- 
se um pico pouco intenso que pode estar relacionado à presença de vermiculita (entre 2 e $8(2 \theta)$ ).

Vale salientar que os Latossolos têm alto poder de adsorção de fósforo (Leal 1971, Novais et al. 1991, Ker 1995). A adsorção tende a se elevar com o aumento de teores de argila, de goethita e de gibbsita no solo, sendo rápida e de difícil reversão.

\subsection{Descrição Mineralógica dos Pós Aplicados na Rochagem}

Para o conhecimento da mineralogia das rochas utilizadas no processo de rochagem, e consequentemente dos possíveis elementos liberados, foram realizados estudos petrográficos de lâminas delgadas de rochas basálticas e de rochas fosfatadas. Além disso, realizaram-se análises de difratometria de raios- $\mathrm{X}$ de todas as amostras antes do uso nos experimentos.

\subsubsection{Mineralogia das Rochas basálticas}

As rochas basálticas utilizadas no experimento de rochagem foram extraídas da Bacia do Paraná que ocupa partes do território do Brasil, Paraguai, Argentina e Uruguai (Machado 2005, Milani et al. 2007). Esta bacia apresenta forma ovalada com direção principal de NNESSW sendo seu contorno dado por limites erosivos relacionados especialmente a geotectônica Mesocenozoica do continente (Figura 3.3) (Milani et al. 2007).

Neste trabalho o enfoque é nas rochas basálticas pertencentes à Formação Serra Geral de idade Juro-Cretácea quando a crosta terrestre foi submetida à acentuada extensão, associado ao magmatismo basáltico resultando no rompimento do megacontinente Gondwana. O vulcanismo prosseguiu até acumular mais de 1500 metros de espessura, que terminou devido ao ajuste isostático litosférico (Milani et al. 2007).

Em um dos mais atuais estudos geocronológicos para a região, Thiede \& Vasconcelos (2010) indicam que o evento eruptivo foi curto por volta de $134,7 \pm 1 \mathrm{Ma}\left({ }^{40} \mathrm{Ar} /{ }^{39} \mathrm{Ar}\right)$.

A Formação Serra Geral corta a seção sedimentar por meio de diques e forma múltiplos níveis de soleiras. Segundo Fodor et al. (1985) e Piccirillo et al. (1987) os corpos vulcânicos apresentam composição basáltica (90\%), andesítica (7\%), riodacítica e riolítica (3\%).

Em um recente estudo petrográfico das rochas basálticas a intermediárias na porção próxima ao estado de Mato Grosso, Machado et al. (2009) descrevem que as rochas apresentam textura hipo ou holocristalina. A granulação é predominantemente fina $(0,1$ a $1 \mathrm{~mm})$, subfanerítica e hipidiomórfica, frequentemente com estrutura maciça sendo as amígdalas e vesículas presentes apenas em topos de derrames. Apresenta mineralogia constituída por plagioclásio (labaradorita-andesina) que representa $40 \%$ a $55 \%$ do volume da rocha total, enquanto que a augita, $19 \%$ a $40 \%$, a pigeonita até $2 \%$; magnetita e illmenita de $2 \%$ a $10 \%$; olivina em até $1,5 \%$ e a apatita até $1,5 \%$. Além disso, a mesóstase chega a representar até $31 \%$ 
da rocha.

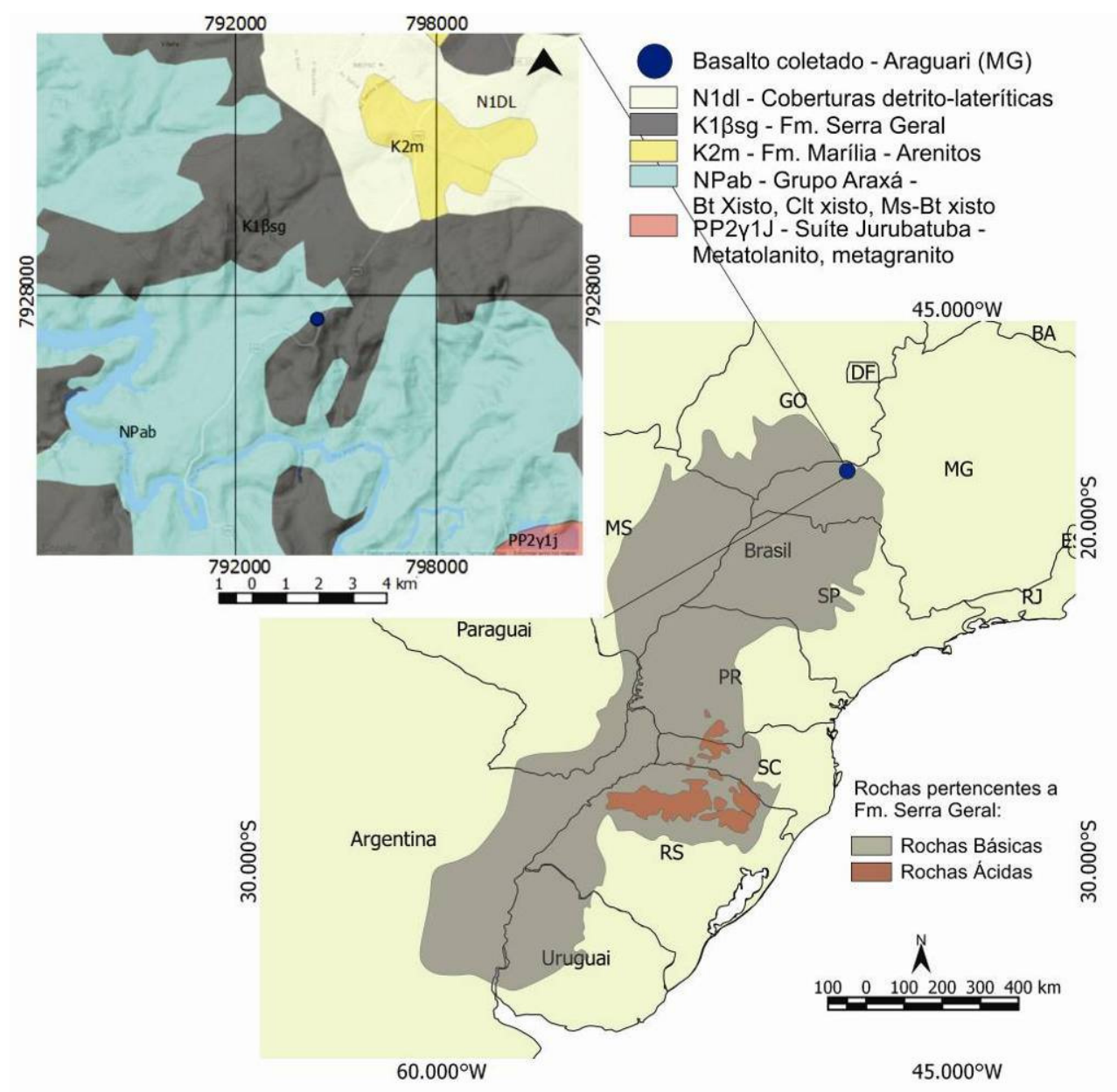

Figura 3.3 - Distribuição das rochas vulcânicas da Formação Serra Geral. Notar a direção NNE-SSW e o predomínio de rochas basálticas. Em detalhe na borda esquerda superior, nota-se o ponto onde foi coletada a amostra próxima à cidade de Araguari (Modificada de Piccirillo \& Melfi 1988; Nardy et al. 2002; Machado 2005; Machado et al. 2009; Sarmento et al. 2013).

Em escala macroscópica, a rocha analisada trata-se de um diabásio de matriz afanítica com presença de ripas de plagioclásio e algumas vesículas (Figura 3.4). Já em lâmina petrográfica pode-se distinguir a seguinte mineralogia: plagioclásio, piroxênio (augita) e mesóstase (vítrea ou microgranular). Ainda possui minerais opacos como a magnetita $3 \%$ e a ilmenita $(2 \%)$.

A presença de microfenocristais de plagioclásio pode ser indicativa de se tratar de um derrame com ampla espessura, tendo sido a amostra obtida da porção central do evento vulcânico. Nas porções basais e de topo dos derrames a textura afanítica e vítrea são mais comumente observadas. 


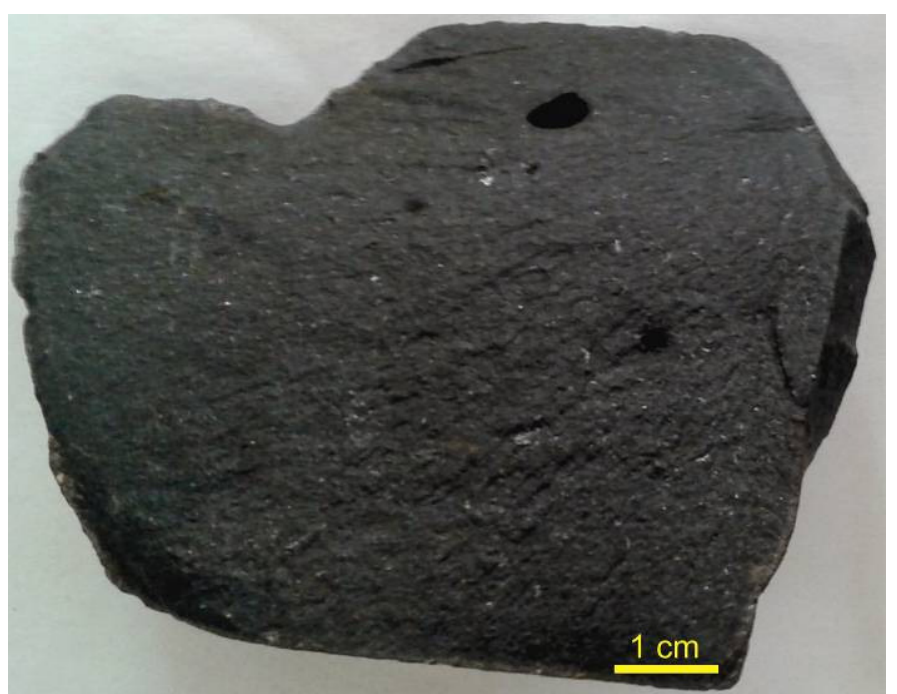

Figura 3.4 - Amostra macroscópica de diabásio evidenciando ripas de plagioclásio com presença de vesículas.

O plagioclásio (45\%) apresenta-se euédrico a subeuédrico, moderadamente alterado, ocasionando uma maior elevação em sua cor de interferência. Não apresenta uma orientação preferencial e estão imersos numa matriz vítrea (textura hialofítica). Apresenta em alguns grãos zonação e textura granofírica que é caracterizada pelo intercrescimento de feldspato alcalino e quartzo microgranular com formas vermiculares ou dendríticas (Figura 3.5).

Ainda, existe nas terminações dos plagioclásios feições do tipo "cauda de andorinha" também denominada de embaiamento, que estão relacionadas com reações descontínuas entre o plagioclásio e o líquido magmático (Machado et al. 2009) (Figura 3.6).

O clinopiroxênio do tipo augita (10\%) é raro na amostra e está bastante alterado, com elevada cor de interferência. Em algumas porções ele é englobado por cristais euhédricos e subhédricos ripiformes de plagioclásio, originando a textura intergranular (Figura 3.7).

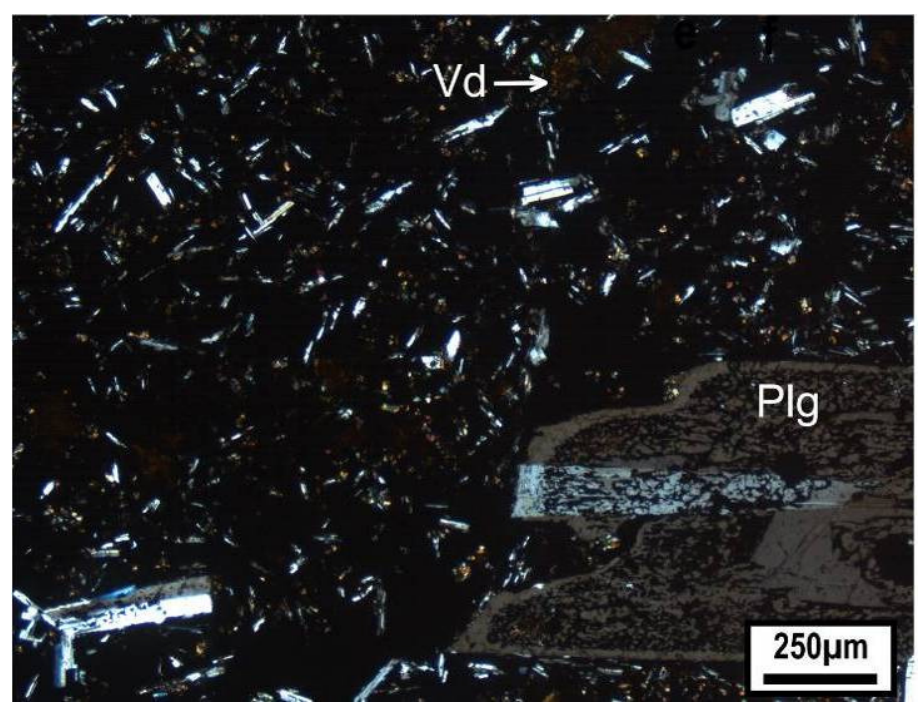

Figura 3.5 - Fotomicrografia do diabásio evidenciado a textura hialofítica onde os cristais de plagioclásio estão imersos na matriz vítrea. Ainda existe um fenocristal de plagioclásio na porção direita inferior, o qual é zonado e se observa textura granofírica. 


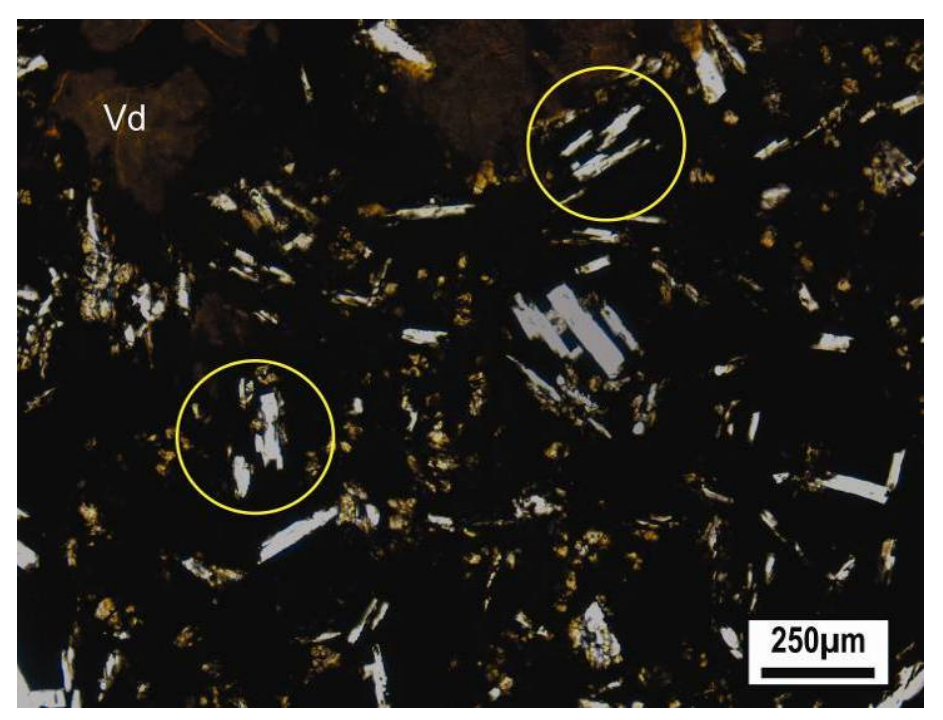

Figura 3.6 - Fotomicrografia do diabásio onde se vê nos círculos amarelos terminações do plagioclásio denominada de "cauda de andorinha". Esta feição também chamada de embaiamento indica a reação descontinua entre o plagioclásio e o liquido magmático residual.

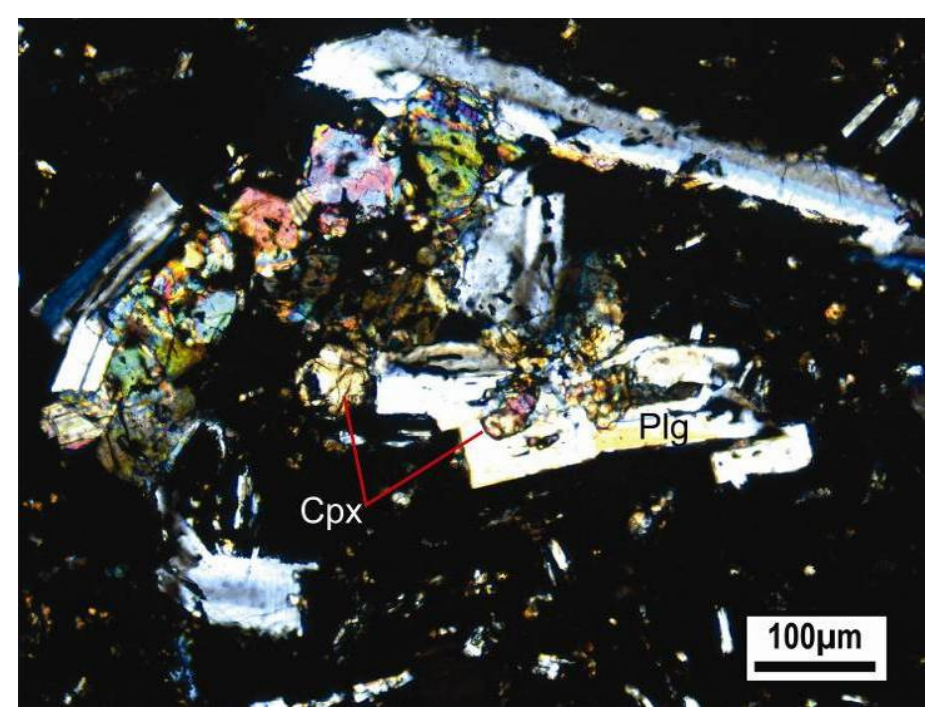

Figura 3.7 - Fotomicrografia detalhando a textura intergranular onde as ripas de plagioclásio englobam cristais de augita (Cpx). Notar a cor de interferência elevada do clinopiroxênio devido a processos de intemperismo.

Por fim, a mesóstase ocupa a matriz da lâmina (40\% do vol.) principalmente na forma vítrea. Pode estar na forma microgranular com microcristais de plagioclásio e piroxênios (micrólitos). Esta elevada quantidade de mesóstase origina a textura do tipo hialofítica que é caracterizada pela presença de matriz vítrea entre cristais de plagioclásio e piroxênio (Figuras $3.5,3.6$ e 3.7$)$.

Análises de difratometria de raios-X reforçam os estudos de lâmina petrográfica, com identificação de picos de augita, anortita, albita e vermiculita (Figura 3.8). É importante a presença da vermiculita (mineral 2:1), pois enfatiza que a amostra já apresenta certo grau de intemperismo, com minerais neoformados. 


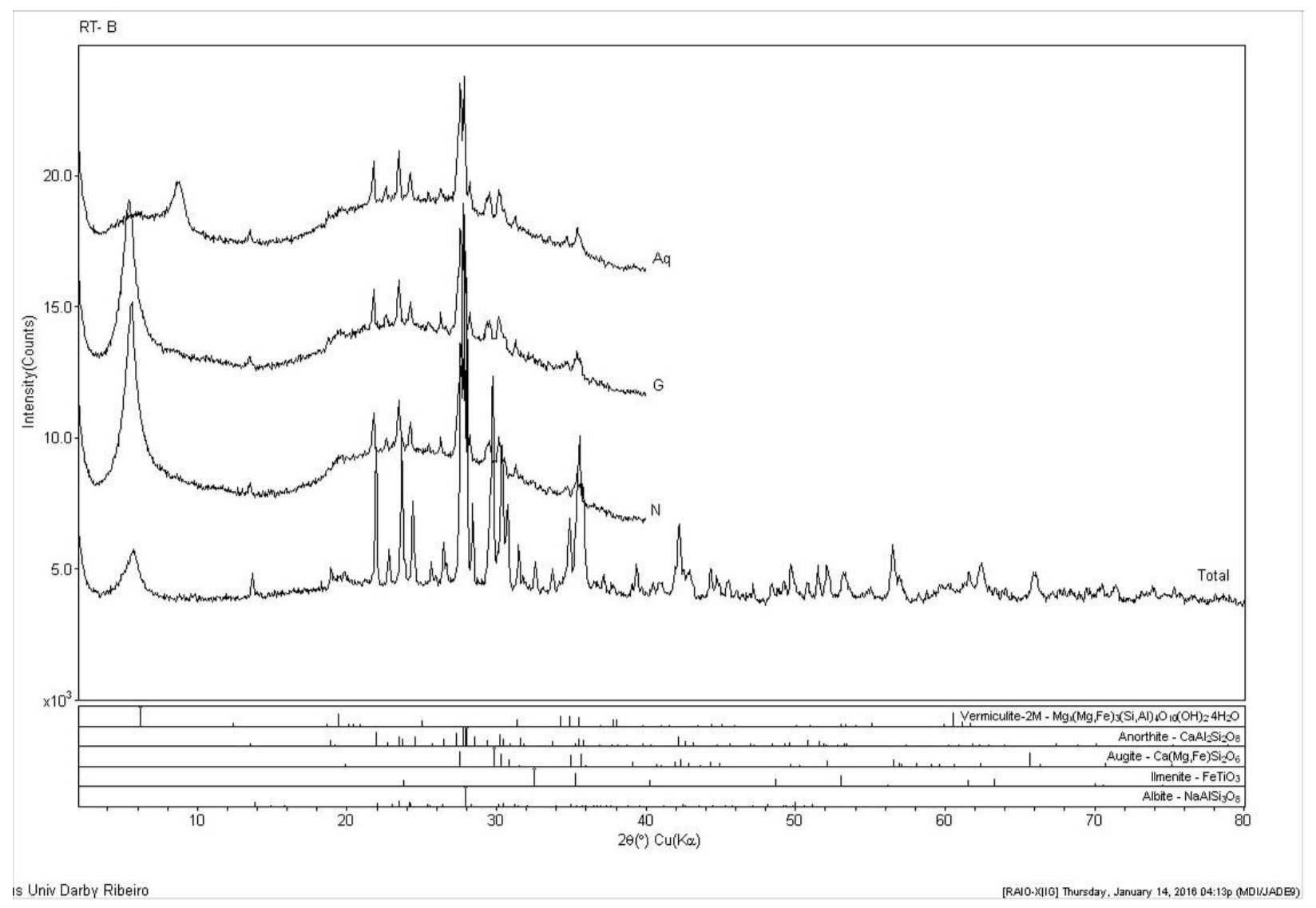

Figura 3.8 - Difratometria de raios-X para amostra de basalto. Notar a presença do pico de vermiculita, indicando presença de processo de intemperismo.

\subsubsection{Mineralogia das Rochas Fosfatadas}

Nas áreas próximas as cidades de Arraias e Taipas ocorrem a seguintes unidades geológicas: Complexo Almas-Cavalcante, Suíte Aurumina, Grupo Araí e Grupo Bambuí (Figura 3.9).

O enfoque será dado apenas ao Grupo Bambuí que é constituído por uma associação de litofácies siliciclásticas, químicas e bioquímicas, formadas pelo acúmulo de sedimentos depositados sobre uma extensiva plataforma epicontinental, onde o mar recobriu grande parte do paleocontinente São Francisco durante o término do Neoproterozoico (Alvarenga et al. 2006).

A distribuição geográfica do Grupo Bambuí, e correlatos, é ampla e contínua ao longo de uma expressiva faixa do Brasil centro-oriental. Distribui-se ao longo de vastas áreas dos estados de Minas Gerais, Bahia, Goiás e parte do Distrito Federal e do Estado de Tocantins (Figura 3.9) (Alvarenga et al. 2006, Dardenne 1979).

Do ponto de vista estratigráfico, Dardenne (1978) subdividiu o grupo em seis formações litoestratigráficas: Jequitaí, Sete Lagoas, Serra de Santa Helena, Lagoa do Jacaré, Serra da Saudade e Três Marias. Atualmente a única diferença, em relação a essa proposta, tem sido a exclusão da unidade inferior - Formação Jequitaí - do Grupo Bambuí e sua incorporação ao Supergrupo São Francisco (Pflug \& Renger 1973, Alvarenga et al. 2006). 


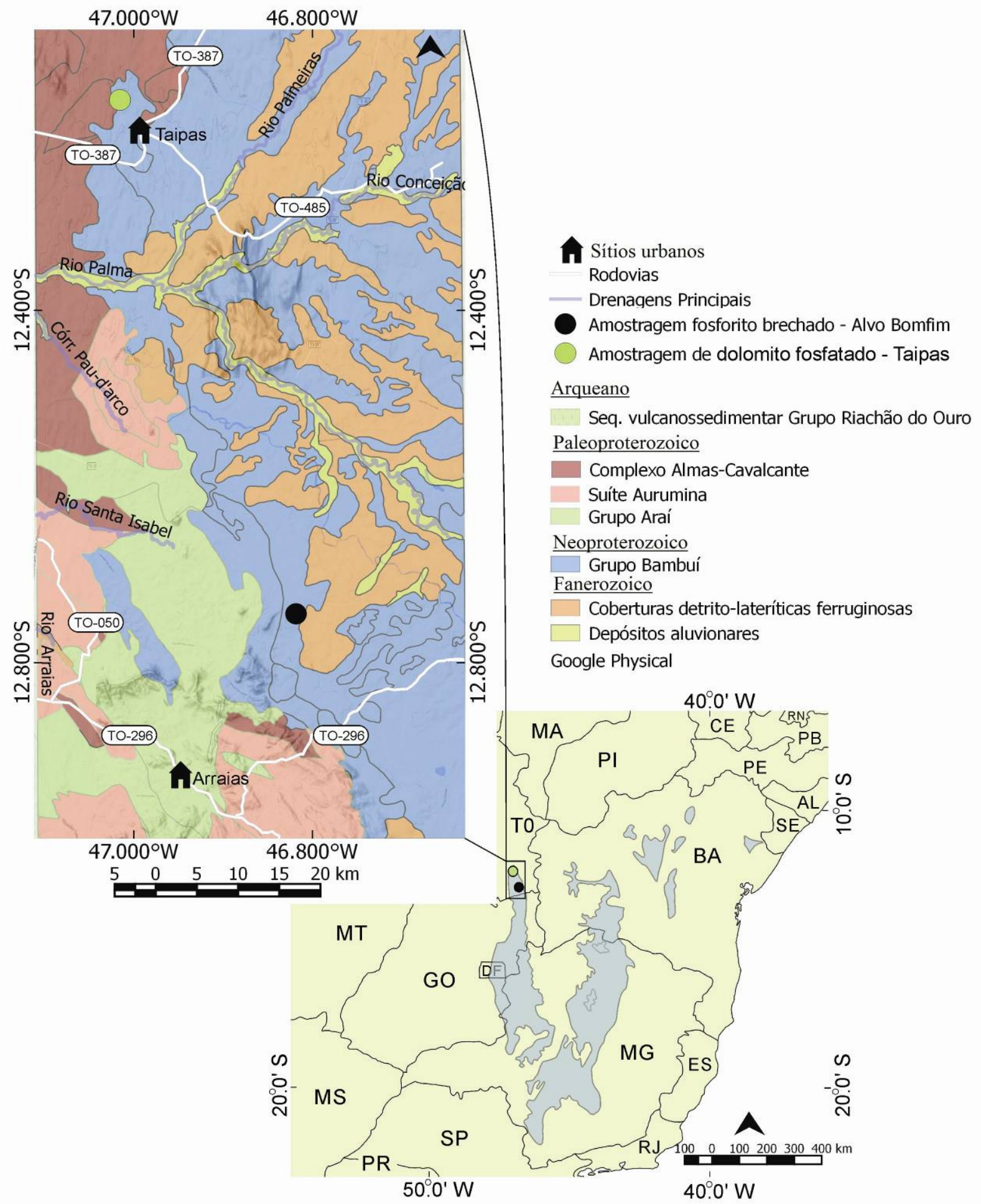

Figura 3.9 - À direita, mapa evidenciando a ocorrência do Grupo Bambuí no Brasil (Adaptado de Dardenne 1979 e 2000). Na porção superior, mapa geológico simplificado da área englobando as cidades de Arraias e Taipas bem como os pontos onde foram coletados o fosforito brechado e o dolomito fosfatado (Adaptado de Abdallah et al. 2013).

No presente estudo serão abordadas as rochas pertencentes à Formação Sete Lagoas, pois é desta unidade que são extraídos os insumos agrícolas utilizados. Esta formação representa uma unidade pelito-carbonática, formada por siltitos, calcários laminados, calcários, dolomitos estromatolíticos, dolarenitos e brechas dolomíticas, depositados em ambientes de intermaré, inframaré e plataforma carbonática (Nobre-Lopes 1995, Lima 1997 e Lima et al. 2007). 
Mais precisamente, as áreas onde foram retiradas as amostras para os experimentos, situam-se próximo ao contato da Suíte Aurumina com a porção inferior da estratigrafia da Formação Sete Lagoas.

Esta suíte corresponde ao embasamento do Grupo Bambuí em sua área tipo. Monteiro (2009) distinguiu duas fácies litológicas: muscovita granitos e biotita-muscovita granitos. Estas rochas apresentam granulação fina a grossa com abundância de veios de quartzo, foliação milonítica e estiramento mineral.

Já a Formação Sete Lagoas na região próxima cidade de Arraias é dividida em três litofácies (Monteiro 2009):

- SLM: é a unidade basal da Formação Sete Lagoas. Constitui-se por margas, fosforitos e siltitos maciços, laminados, calcíferos e fosfatados.

- SLC: compreende calcários laminados por vezes bandados e calcários de cor cinza. É a litofácies mais delgada dessa formação.

- $S L D$ : constitui-se por extensas lentes de rochas dolomíticas que formam grandes paredões rochosos ruineformes e se sobrepõe aos siltitos, ao longo da direção NNW-SSE, acompanhando o embasamento granítico.

Segundo Monteiro (2009) os fosforitos, de maneira geral, ocorrem encaixados no embasamento granítico, interdigitados com siltitos e siltitos fosfatados de forma irregular e pouco espesso. A maioria segue o alinhamento NNW-SSE.

No local de coleta (Alvo Bomfim) os afloramentos ocorrem em pequenos morros com aspecto de matacões fortemente silicificados com hábito botroidal e cor variando entre bege, rosa, amarela, vermelha e marrom. As rochas possuem diversas cavidades que são preenchidas por quartzo e apatita neoformada, razão pela qual as rochas são tão silicificadas.

$\mathrm{Na}$ etapa de campo foi possível realizar um perfil esquemático de como se encontram as rochas fosfatadas da região (Figura 3.10). Interpretou-se que esse material foi depositado em paleocanais sobre os granitos do embasamento. A lama colofanítica inicialmente forma as fácies primárias descritas como fosforitos finos laminados. Posteriormente, devido ao retrabalhamento dessas rochas formam-se as fácies de fosforitos brechados. Apenas em uma localidade (ao sul do Morro do Bomfim) ocorrem fosforitos coluvionares formados pelo retrabalhamento de fosforitos brechados a pequenas distâncias (entre 0 e $3 \mathrm{~km}$ a partir da área fonte).

As fácies carbonáticas são depositadas nas porções elevadas do paleorelevo, sendo que dolomitos ocorrem sistematicamente na base das sucessões, os quais são sobrepostos por fosforitos e calcários. De forma geral os carbonatos são representados por fácies micritícas e apenas localmente ocorrem fácies mais grossas representadas por calciruditos intraclásticos. 
E

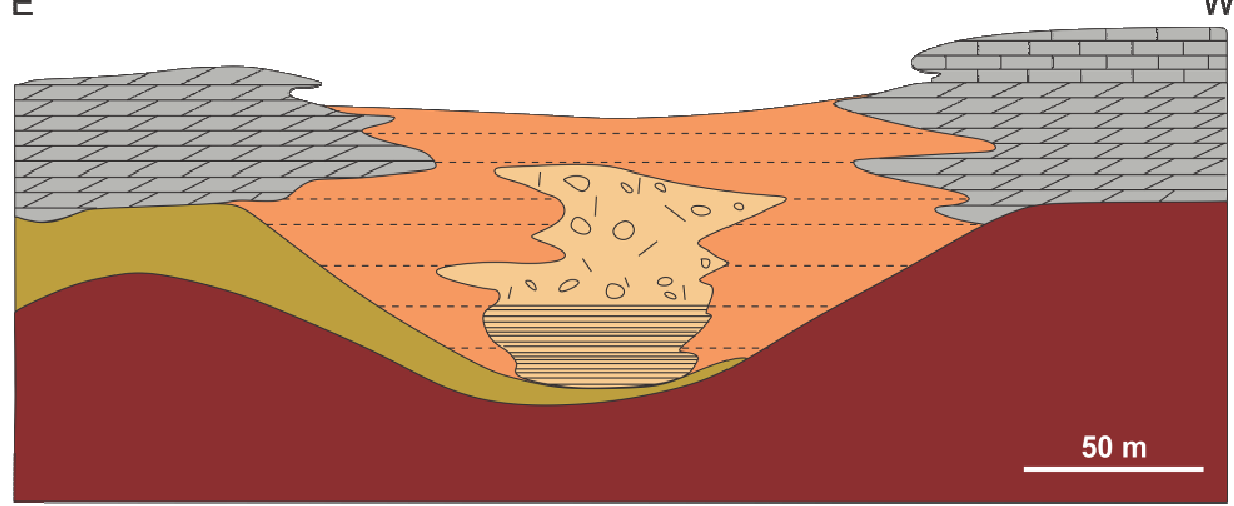

Grupo Bambui:

\begin{tabular}{|c|c|c|}
\hline Fosforito laminado & 臣 Lentes carbonáticas & Embasamento \\
\hline $\begin{array}{ll}0 \\
0\end{array}$ & Dolc & nítico \\
\hline Siltito fosfatado & Arc & \\
\hline
\end{tabular}

Figura 3.10 - Perfil esquemático do Alvo Bomfim, destacando a ocorrência de fosforito laminado, brechado e siltito fosfatado oriundo de paleocanais encaixados no embasamento granítico, sendo o topo do paleorelevo constituído por rochas carbonáticas.

A amostra utilizada no processo de rochagem apresenta-se bastante friável sendo de difícil análise em escala macroscópica o aspecto brechado (Figura 3.11). Já em lâmina delgada fica mais visível o aspecto brechado e a presença de uma matriz colofanítica bem como a ocorrência de material interclasto que é representado por agulhas de apatita diagenética com alto grau de cristalinidade (Figura 3.12).

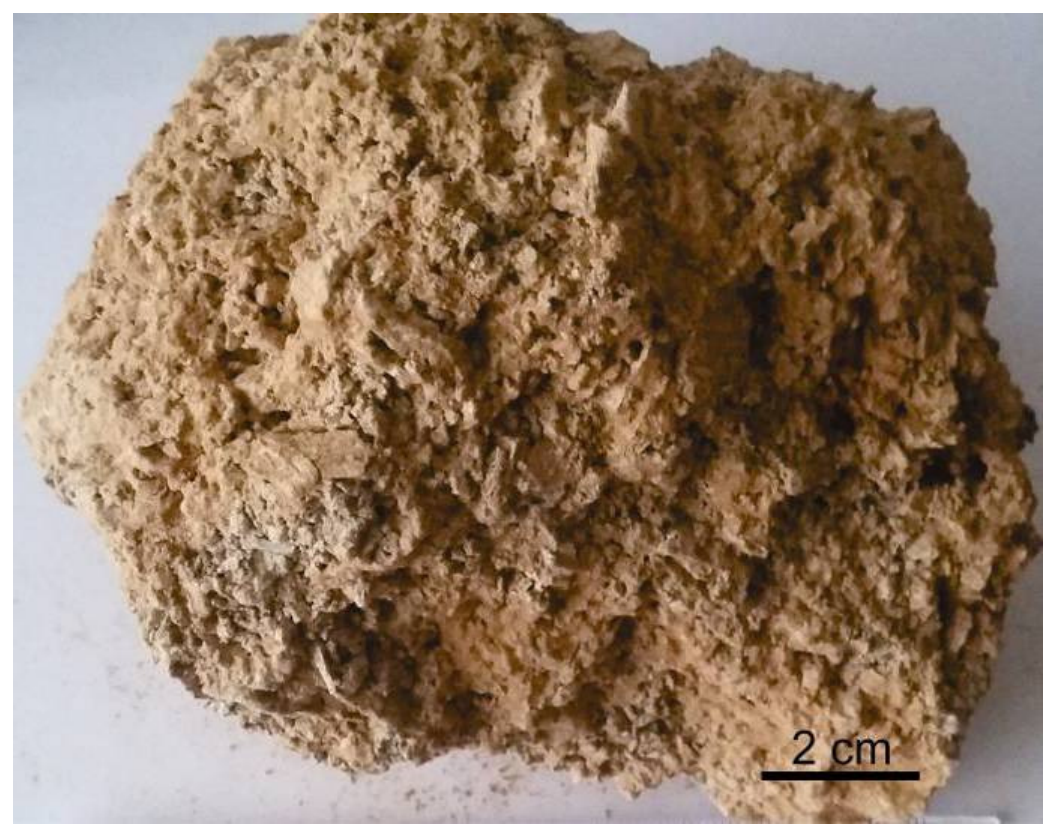

Figura 3.11 - Fotografia de amostra macroscópica evidenciando o aspecto brechado e bastante friável do fosforito utilizado no processo de rochagem. 


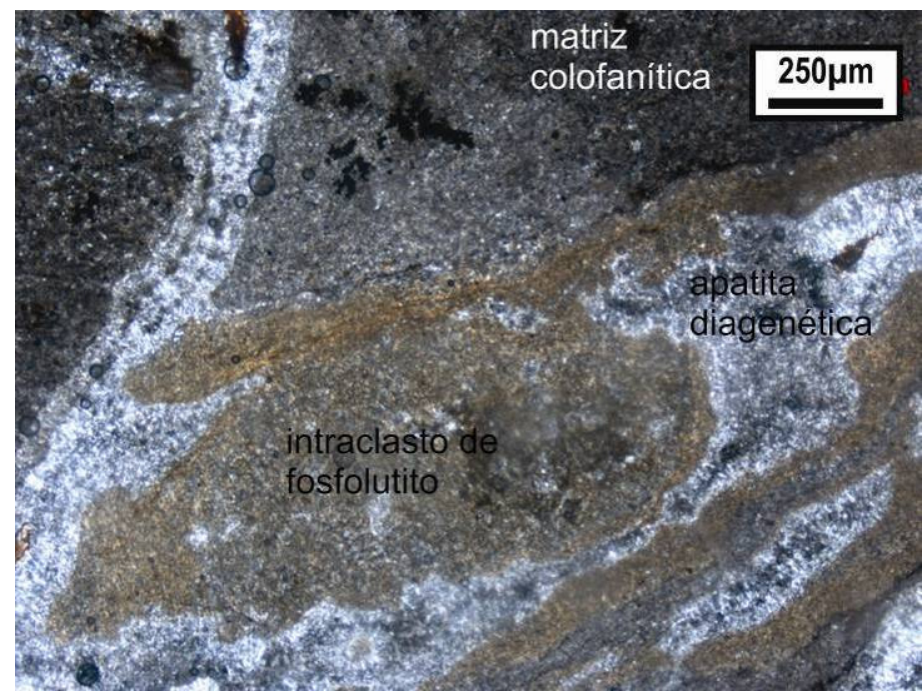

Figura 3. 12 - Fotomicrografia de fosforito brechado pertencente ao Alvo Bomfim, onde se visualiza o fosforudito com intraclasto de fosfolutito em matriz colofanítica. Notar também a presença de apatita diagenética com alto grau de cristalinidade.

A difratometria de raios- $X$ indicou a presença de quartzo, fluorapatita e minerais do grupo dos filossilicatos como caulinita, muscovita e vermiculita (Figura 3.13).

Isso indica que o processo intempérico foi moderado, pois existem ainda argilominerais com estrutura 2:1 e a presença da fluorapatita, oriunda provavelmente da transformação da estrutura original da francolita por meio de processos intempéricos, metamórficos e/ou diagenéticos (McClellan 1980, Lima et al. 2007, Monteiro 2009). Esse processo de transformação já é amplamente conhecido na literatura e inicia-se com a francolita que pertence ao grupo da apatita com teores significativos de $\mathrm{CO}_{2}$ e flúor (1\%) (McClellan 1980 e Deer et al. 1992).

Com o avanço do processo intempérico a apatita primária sedimentar (francolita), perde gradativamente $\mathrm{CO}_{2}$ podendo chegar a formar fosfatos de ferro e alumínio com a neoformação da caulinita, entretanto, se houver associação com rochas carbonáticas pode ocorrer à interrupção no estágio evolutivo, alcançando somente a mineralogia de fluorapatita (McClellan 1980, Lucas et al. 1980, Flicoteaux \& Lucas 1984 e Ferrari 2000).

Segundo Monteiro (2009) as rochas fosfatadas na região se enquadram majoritariamente no padrão da fluorapatita e que a razão $\mathrm{CaO} / \mathrm{P}_{2} \mathrm{O}_{5}$ tende a aumentar em estágios mais avançados de intemperismo devido a perda do fosfato da estrutura da apatita especialmente em ambiente oxidante com percolação de águas ácidas. Isso contradiz o estudo clássico de Gusev et al. (1976) que indica que o primeiro elemento a ser removido da apatita é o flúor seguido pelo cálcio e posteriormente o fósforo. 


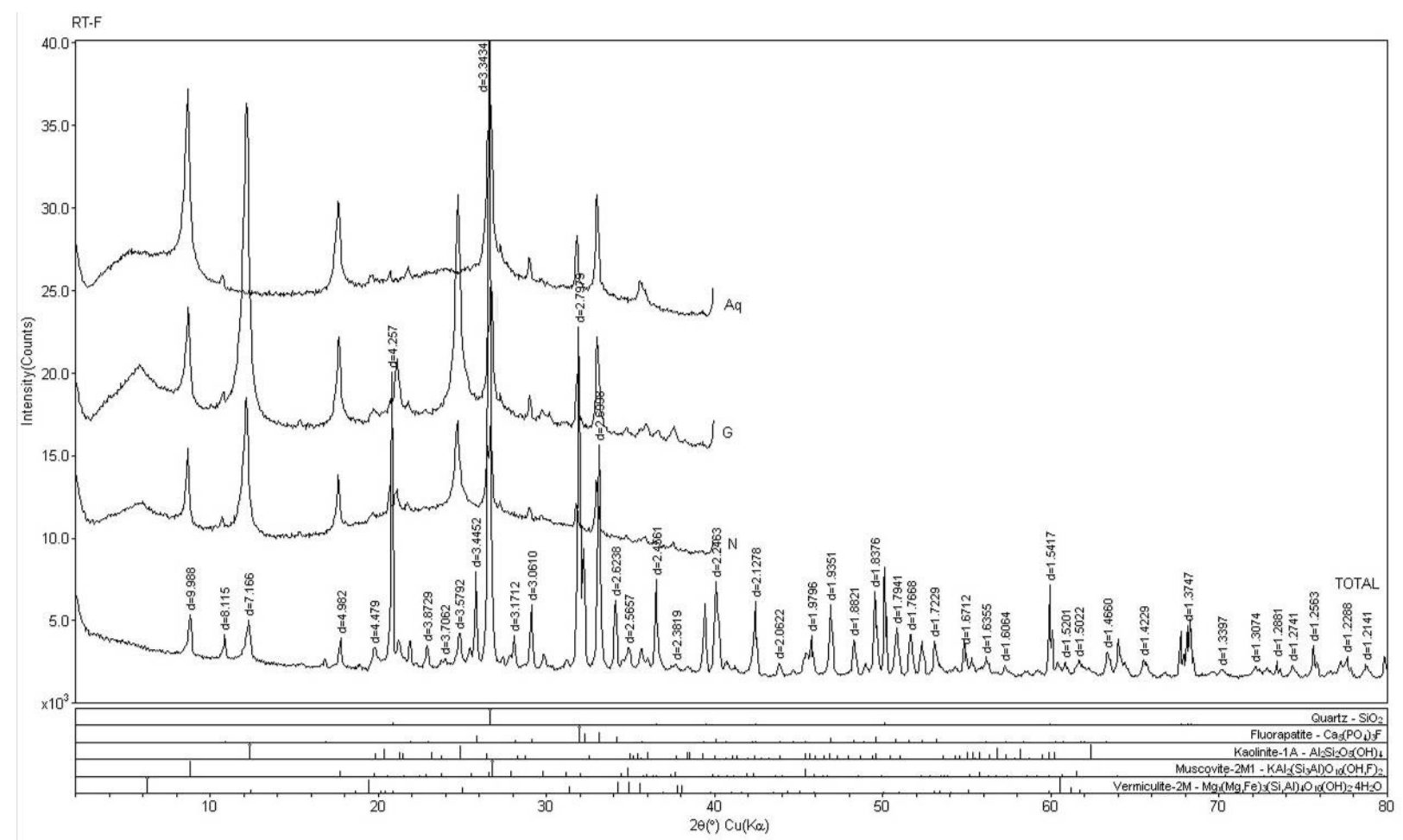

Figura 3.13 - Difratometria de raios-X indicando a presença de uma mineralogia com grãos de quartzo, fluorapatita, caulinita, muscovita e vermiculita.

O dolomito fosfatado extraído na região de Taipas apresenta gênese semelhante ao sistema de paleocanais explanado anteriormente e trata-se de um dololutito fosfatado foliado de cor cinza esbranquiçada. Não é possível a distinção mineralógica em amostra de mão. Deste modo, realizou-se difratometria de raios- $\mathrm{X}$ que indicou a presença de calcita, dolomita, quartzo e ilita (Figura 3.14). Notar que não se encontrou minerais do grupo da apatita, isso não significa a sua inexistência, somente que em baixas concentrações a difratometria de raios-X não é um método eficiente. Essa baixa concentração é confirmada pela FRX, onde se nota um teor de $\mathrm{P}_{2} \mathrm{O}_{5}$ de $2,5 \%$.

\subsection{Geoquímica dos Insumos Utilizados no Experimento de Rochagem}

As análises geoquímicas de fluorescência de raios-X (FRX) e de fertilidade padrão do solo foram realizadas antes do plantio, com amostras de Latossolo, basalto, fosforito, dolomito fosfatado e fertilizante solúvel.

Além disso, no decorrer do tempo, foram realizadas análises de fluorescência de raios-X, para verificar o comportamento dos componentes presentes no solo, especialmente os não solúveis. Por fim, após dois plantios (em um ano de experimento) foram realizados testes de fertilidade do solo. 


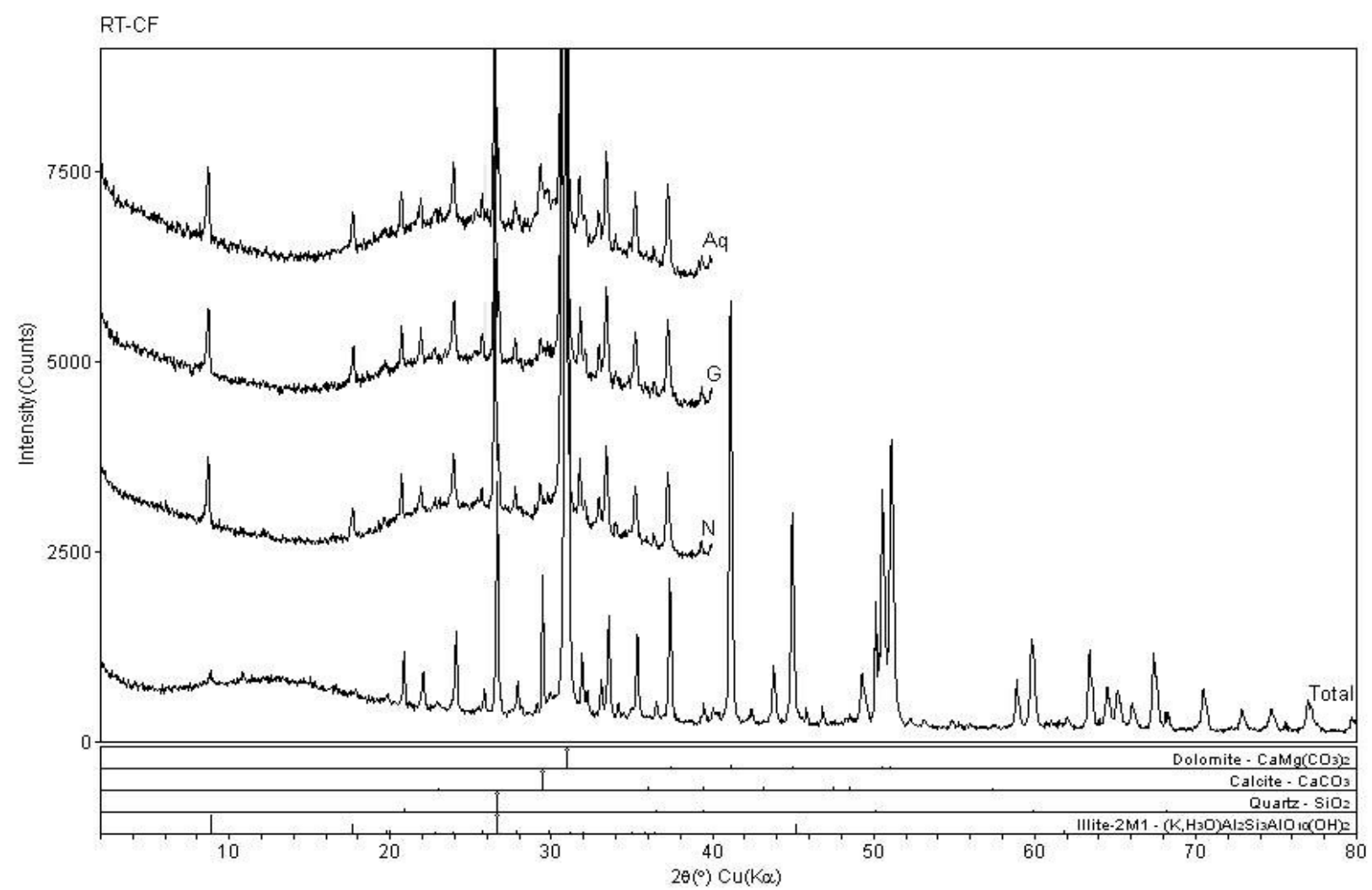

Figura 3.14 - Difratometria de raios-X indicando a presença de dolomita, calcita, quartzo e ilita. Minerais do grupo da apatita não foram observados devido a sua baixa concentração.

\subsubsection{Geoquímica dos Insumos Aplicados Antes do Plantio}

As análises de FRX antes do plantio das amostras de Latossolo (L1), Basalto (B), fosforito (F), dolomito fosfatado (DF) e fertilizante solúvel (NPK) permitiram visualizar os elementos constituintes de cada material. Já a análise com uso de método padrão para solo permitiu compreender a disponibilidade dos elementos para as plantas.

No caso do Latossolo, nota-se a presença majoritária de óxidos de alumínio (49\%), ferro $(25,8 \%)$ sílica $(19,8 \%)$ e titânio (3,6\%) (Tabela 3.2). Esses dados estão de acordo com a mineralogia dada pela DRX que indicou a presença predominante de caulinita, goethita, gibbsita, hematita e quartzo. Secundariamente de ilita, anatásio e rutilo.

No caso da análise de fertilidade de solo apresenta um valor relativamente baixo de saturação por bases (27\%) sendo classificado como distrófico (Tabela 3.3). Segundo Sousa \& Lobato (2004) em estudos realizados para colheitas anuais no cerrado, a CTC de $8 \mathrm{cmol}_{\mathrm{c}} / \mathrm{dm}^{3}$ é considerada média. $\mathrm{O}$ pH em $\mathrm{H}_{2} \mathrm{O}$ de 5,7 é adequado embora levemente ácido e o fósforo disponível é considerado baixo para o extrator resina trocadora de íons e médio para o extrator Mehlich. Apresenta ainda baixas concentrações de $\mathrm{Mg}^{2+}, \mathrm{K}^{+}$, adequada de $\mathrm{Ca}^{2+} \mathrm{e}$ alta de matéria orgânica. Por fim segundo Osaki (1991) a saturação por alumínio é medianamente prejudicial de $16 \%$. 
Vale lembrar que um baixo índice de saturação por bases significa que há pequenas quantidades de cátions, como $\mathrm{Ca}^{2+}, \mathrm{Mg}^{2+} \mathrm{e} \mathrm{K}^{+}$, saturando as cargas negativas dos coloides e que a maioria delas está sendo neutralizada por $\mathrm{H}^{+}$e $\mathrm{Al}^{3+}$ (Ronquim 2010).

A amostra de basalto apresenta elevados teores de sílica (42,7\%), ferro (23,1\%), alumínio (11,5\%), cálcio $(9,9 \%)$ magnésio $(4,4 \%)$ e titânio (3,9\%) (Tabela 3.2). Teores menores, porém de grande importância são dos óxidos de sódio (1,9\%) e potássio (1,1\%). Esses elementos apresentam coerência com os minerais contidos na rocha (augita, plagioclásio, vidro e ilmenita).

A amostra apresenta elevada CTC de $25 \mathrm{cmol}_{\mathrm{c}} / \mathrm{dm}^{3}$ e muito alta de saturação por bases (95\%). Ainda apresenta alto fósforo disponível em ambos os extratores bem como de altos valores de $\mathrm{Ca}^{2+}, \mathrm{Mg}^{2+}$ e $\mathrm{pH}$ em $\mathrm{H}_{2} \mathrm{O}$. Por fim, há baixos teores de $\mathrm{K}^{+}$, M.O e saturação em alumínio (Sousa \& Lobato 2004) (Tabela 3.3).

O fosforito brechado apresenta importante quantidade de óxidos de silício $(56,0 \%)$, alumínio $(13,8 \%)$, cálcio $(9,7 \%)$, ferro $(8,8 \%)$, fósforo $(7,3 \%)$ e potássio $(2,0 \%)$ (Tabela 3.2). A alta presença de sílica e alumínio se justifica especialmente pela presença de quartzo e caulinita. Já a percentagem de fósforo se deve a fluorapatita e a de potássio a muscovita.

Este fosforito apresenta alto valores de saturação por bases $(67 \%), \mathrm{pH}$ em $\mathrm{H}_{2} \mathrm{O}(6,1)$ e $\mathrm{P}$ disponível em ambos os extratores. Apresenta moderada a adequada quantidade de CTC e dos íons $\mathrm{Ca}^{2+}, \mathrm{Mg}^{2+}$. Por fim, há baixas concentrações de $\mathrm{K}^{+}$, M.O e saturação por alumínio (Tabela $3.3)$.

O dolomito fosfatado apresenta teores significativos de óxidos de cálcio (61,0\%), magnésio $(20,8 \%)$, sílica $(9,1 \%)$, ferro $(3,5 \%)$, fósforo $(2,4 \%)$ e alumínio $(2,0 \%)$ (Tabela 3.2). Como observado para as demais amostras descritas, os resultados apresentam boa relação com a mineralogia, rica em dolomita, apatita e óxidos de ferro.

Já em relação à presença de nutrientes disponíveis para as plantas, apresentou caráter eutrófico com elevado teor de saturação por bases (87\%), além disso, verificou-se altos teores de $\mathrm{pH}(8,2)$ e P disponível de $134 \mathrm{mg} / \mathrm{dm}^{3}$ para o extrator mehlich e de $1207 \mathrm{mg} / \mathrm{dm}^{3}$ para resina trocadora de íons. Por fim, possuem valores moderados de cálcio $\left(4,7 \mathrm{cmol}_{\mathcal{c}} / \mathrm{dm}^{3}\right)$ e magnésio 1,8 $\mathrm{cmol}_{\mathrm{c}} / \mathrm{dm}^{3}$ ) e baixa saturação por alumínio (9\%) (Tabela 3.3) (Sousa \& Lobato 2004).

O fertilizante solúvel apresentou significativa proporção de óxidos de fósforo (29,6\%), cálcio $(24,5 \%)$, enxofre $(20,403 \%)$, potássio $(15,1 \%)$, ferro $(3,7 \%)$ e sílica $(1,7 \%)$ (Tabela 3.2$)$.

Em um simples estudo comparativo da percentagem dos elementos por meio da fluorescência de raios-X, nota-se que o fertilizante solúvel é o que apresenta maior quantidade de macronutrientes como o $\mathrm{K}_{2} \mathrm{O}, \mathrm{P}_{2} \mathrm{O}_{5}$ e $\mathrm{SO}_{3}$ chegando a $65,2 \%$ do material, seguidos pelo fosforito brechado, calcário fosfatado, basalto e o Latossolo (Figura 3.15). 
Tabela 3.2 - Relação em porcentagem dos óxidos e elementos por meio de fluorescência de raios-X para: Latossolo (L), Basalto (B), Fosforito brechado (F), Dolomito fosfatado (DF) e fertilizante solúvel (NPK). Estas análises ocorreram antes do início do experimento. Vale lembrar que o teor de nitrogênio não foi calculato por esta técnica.

\begin{tabular}{|l|c|c|c|c|c|}
\hline & RT - L & RT - B & RT - F & RT - DF & RT - NPK \\
\hline $\mathrm{SiO}_{2}$ & $19,895 \%$ & $42,772 \%$ & $56,016 \%$ & $9,108 \%$ & $1,701 \%$ \\
\hline $\mathrm{Al}_{2} \mathrm{O}_{3}$ & $49,058 \%$ & $11,586 \%$ & $13,865 \%$ & $2,025 \%$ & $0,724 \%$ \\
\hline $\mathrm{MgO}$ & $0,129 \%$ & $4,489 \%$ & $0,957 \%$ & $20,836 \%$ & $0,824 \%$ \\
\hline $\mathrm{Fe}_{2} \mathrm{O}_{3}$ & $25,801 \%$ & $23,153 \%$ & $8,825 \%$ & $3,516 \%$ & $3,766 \%$ \\
\hline $\mathrm{CaO}$ & $0,077 \%$ & $9,906 \%$ & $9,723 \%$ & $61,036 \%$ & $24,518 \%$ \\
\hline $\mathrm{Na}_{2} \mathrm{O}$ & $0,017 \%$ & $1,985 \%$ & $0,029 \%$ & $0,009 \%$ & $0,812 \%$ \\
\hline $\mathrm{K}_{2} \mathrm{O}$ & $0,814 \%$ & $1,159 \%$ & $2,045 \%$ & $0,597 \%$ & $15,145 \%$ \\
\hline $\mathrm{TiO}_{2}$ & $3,649 \%$ & $3,981 \%$ & $0,744 \%$ & $0,151 \%$ & $0,737 \%$ \\
\hline $\mathrm{P}_{2} \mathrm{O}_{5}$ & $0,149 \%$ & $0,379 \%$ & $7,371 \%$ & $2,454 \%$ & $29,688 \%$ \\
\hline $\mathrm{MnO}$ & $0,053 \%$ & $0,267 \%$ & $0,272 \%$ & $0,069 \%$ & $0,305 \%$ \\
\hline $\mathrm{SO} \mathrm{O}_{3}$ & $0,097 \%$ & $0,044 \%$ & $0,015 \%$ & $0,121 \%$ & $20,403 \%$ \\
\hline $\mathrm{Sr}$ & $0,0030 \%$ & $0,0930 \%$ & $0,0240 \%$ & $0,0380 \%$ & $0,4690 \%$ \\
\hline $\mathrm{Rb}$ & $0,0070 \%$ & $0,0040 \%$ & $0,0090 \%$ & $0,0030 \%$ & $0,0030 \%$ \\
\hline $\mathrm{Ni}$ & $0,0080 \%$ & $0,0160 \%$ & $0,0130 \%$ & $0,0050 \%$ & $0,0110 \%$ \\
\hline $\mathrm{Cu}$ & $0,0070 \%$ & $0,0350 \%$ & $0,0070 \%$ & $0,0050 \%$ & $0,0140 \%$ \\
\hline $\mathrm{Zn}$ & $0,0070 \%$ & $0,0200 \%$ & $0,0160 \%$ & $0,0050 \%$ & $0,6700 \%$ \\
\hline $\mathrm{Zr}$ & $0,1600 \%$ & $0,0510 \%$ & $0,0300 \%$ & $0,0100 \%$ & $0,1170 \%$ \\
\hline $\mathrm{Cr}$ & $0,0220 \%$ & $0,0090 \%$ & $0,0090 \%$ & $0,0090 \%$ & $0,0040 \%$ \\
\hline $\mathrm{V}$ & $0,0180 \%$ & $0,0380 \%$ & $0,0090 \%$ & $0,0020 \%$ & $0,0060 \%$ \\
\hline $\mathrm{Co}$ & $0,0010 \%$ & $0,0080 \%$ & $0,0040 \%$ & $0,0000 \%$ & $0,0080 \%$ \\
\hline $\mathrm{Nb}$ & $0,0100 \%$ & $0,0030 \%$ & $0,0010 \%$ & $0,0000 \%$ & $0,0590 \%$ \\
\hline $\mathrm{Pb}$ & $0,0090 \%$ & $0,0010 \%$ & $0,0180 \%$ & $0,0020 \%$ & $0,0150 \%$ \\
\hline $\mathrm{Total}$ & $99,9910 \%$ & $99,9990 \%$ & $100 \%$ & $100 \%$ & $99,9990 \%$ \\
\hline
\end{tabular}

Tabela 3.3 - Análise padrão de solo para os materiais antes da aplicação no experimento. Amostras de Latossolo, basalto, fosforito brechado e dolomito fosfatado.

\begin{tabular}{|c|c|c|c|c|c|c|c|c|c|c|c|c|c|c|c|c|}
\hline \multirow[t]{2}{*}{ Tratamento } & \multicolumn{6}{|c|}{ Complexo Sortivo } & \multicolumn{3}{|c|}{ Valor } & \multicolumn{2}{|c|}{ Sat. } & $\mathrm{pH}$ & \multicolumn{2}{|c|}{ P. Disp. } & M.O & $\mathbf{C}$ \\
\hline & $\mathrm{Ca}^{2+}$ & $\mathrm{Mg}^{2+}$ & $\mathrm{K}^{+}$ & $\mathrm{Na}^{+}$ & $\mathrm{Al}^{3+}$ & $\begin{array}{l}\mathrm{Al} \\
+\mathrm{H}\end{array}$ & S B & CTC & V & $\mathrm{Al}$ & $\mathrm{Na}$ & \multirow[t]{2}{*}{$\mathrm{H}_{2} \mathrm{O}$} & $\begin{array}{c}\text { Mehli } \\
\text { ch }\end{array}$ & Resina & \multirow{2}{*}{\multicolumn{2}{|c|}{$\mathrm{g} / \mathrm{kg}$}} \\
\hline & \multicolumn{8}{|c|}{$\mathrm{cmol}_{\mathrm{c}} / \mathrm{dm}^{3}$} & \multicolumn{3}{|c|}{$\%$} & & \multicolumn{2}{|c|}{$\mathrm{mg} / \mathrm{dm}^{3}$} & & \\
\hline Latossolo & 1,6 & 0,3 & 0,19 & 0,09 & 0,4 & 5,8 & 2,18 & 8,0 & 27,0 & 16,0 & 1,1 & 5,7 & 5,9 & 8,2 & 76,0 & 44,2 \\
\hline Basalto & 16,4 & 3,0 & 0,45 & 3,9 & 0,0 & 1,3 & 23,75 & 25 & 95,0 & 0 & 15,6 & 8,6 & 655,0 & 263,0 & 4,6 & 2,7 \\
\hline $\begin{array}{l}\text { Fosforito } \\
\text { Brechado }\end{array}$ & 4,3 & 1,1 & 0,06 & 0,12 & 0,0 & 2,7 & 5,58 & 8,0 & 67,0 & 0 & 1,4 & 6,1 & 7317 & 297 & 19,4 & 11,3 \\
\hline $\begin{array}{l}\text { Dolomito } \\
\text { fosfatado }\end{array}$ & 4,7 & 1,8 & 0,05 & 0,01 & 0,7 & 1,0 & 6,56 & 7,56 & 87,0 & 9 & 0,1 & 8,2 & 134 & 1207 & 5,0 & 2,9 \\
\hline
\end{tabular}

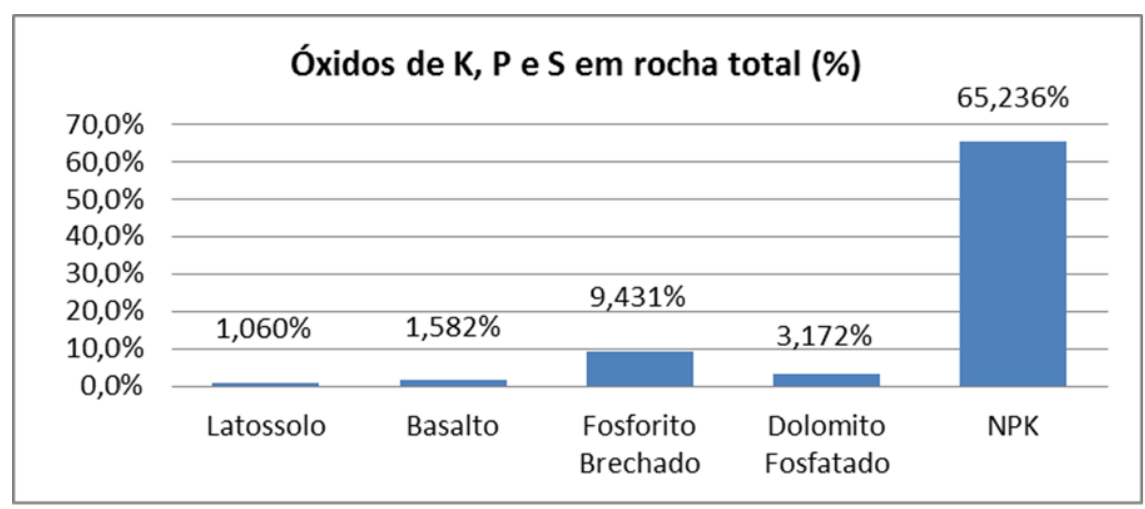

Figura 3.15 - Gráfico ilustrando a percentagem dos macronutrientes $\mathrm{K}_{2} \mathrm{O}, \mathrm{P}_{2} \mathrm{O}_{5}$ e $\mathrm{SO}_{3}$ em rocha total analisados pela técnica de FRX. Notar a elevada superioridade do fertilizante solúvel NPK se comparado com os demais materiais. Vale lembrar que o teor de nitrogênio não foi calculato por esta técnica. 
O fertilizante solúvel (NPK) também apresenta uma maior proporção de micronutrientes quando se analisa os teores de $\mathrm{Ni}, \mathrm{Cu}, \mathrm{Zn}, \mathrm{Co}$ e $\mathrm{MnO}$ (Figura 3.16). Outros teores significativos estão relacionados com o basalto e o fosforito, já o dolomito fosfatado e o Latossolo apresentam baixíssimos teores. Vale ressaltar que elevados teores de micronutrientes não necessariamente significam elevada produtividade, pois o intervalo entre as concentrações ótima e tóxica no solo é, em regra, bastante restrito (Lapido-Loureiro \& Nascimento 2009). Nesta análise foi excluído o micronutriente $\mathrm{FeO}$ devido a elevada presença no ambiente.

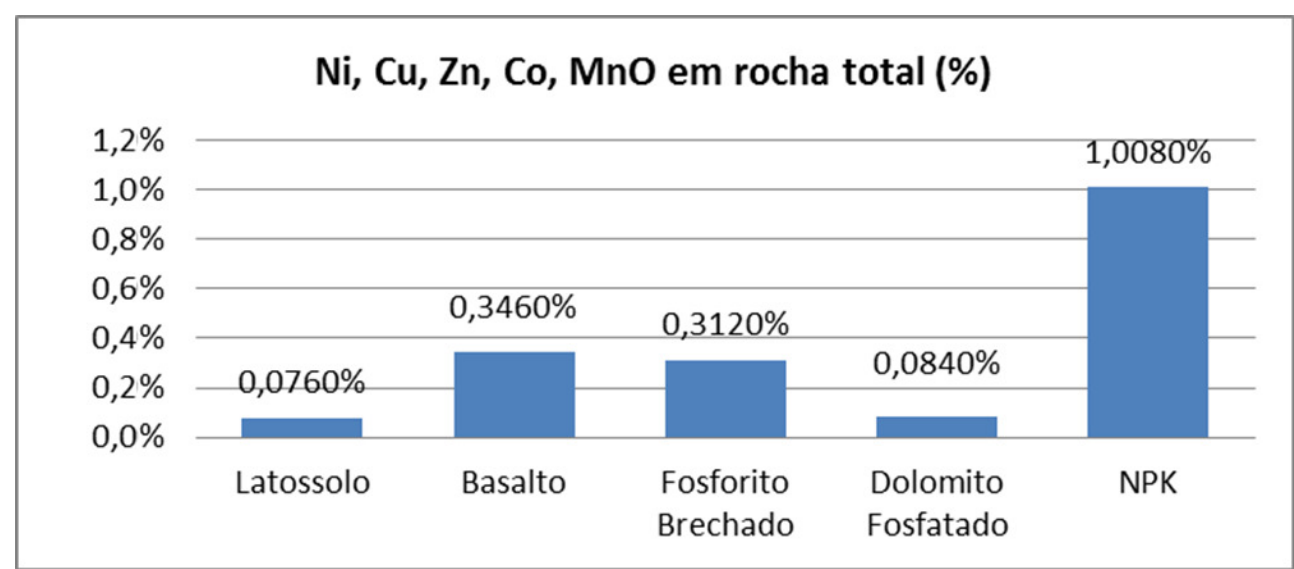

Figura 3.16 - Gráfico com percentagem dos micronutrientes em rocha total analisados pela técnica de FRX. Notar ainda os maiores teores relacionados ao fertilizante solúvel (NPK).

Entretanto, se analisado somente os macronutrientes mais correlacionados com a correção do $\mathrm{pH}$ (Ca e $\mathrm{Mg}$ ), nota-se que o dolomito fosfatado é o que apresenta maiores concentrações totalizando $81,8 \%$ da rocha, seguido pelo NPK, basalto, fosforito e Latossolo (Figura 3.17).

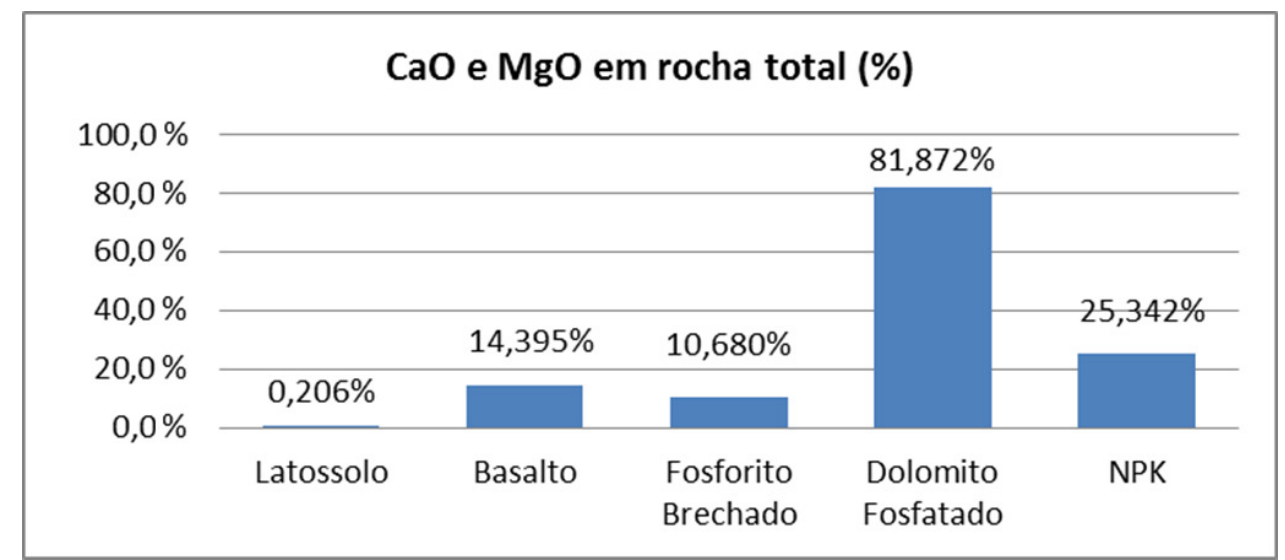

Figura 3. 17 - Gráfico com a presença de macronutrientes especialmente ligados ao ajuste do $\mathrm{pH}(\mathrm{CaO}$ e $\mathrm{MgO}$ ) analisados pela técnica de FRX. Notar a significativa quantidade destes óxidos em todos os insumos aplicados ao Latossolo, especialmente no caso do dolomito fosfatado.

\subsubsection{Geoquímica de Fluorescência de Raios-X Durante um Ano de Plantio}

A fluorescência de raios- $X$, tem como finalidade a determinação de elementos na forma insolúvel. Deste modo, um estudo contínuo ao longo do ano se faz necessário. No presente experimento se realizaram três etapas de análises de fluorescência de raios-X (FRX) a cada quatro meses. 
O mais importante neste tipo de análise é comparar a quantidade de elementos disponíveis no início do experimento com aqueles observados ao fim. Deste modo, verificando a proporção de elementos perdidos para o sistema ao longo do ano, é possível inferir quais misturas de rocha apresentam maior ou menor disponibilização de nutrientes para às plantas. Como a quantidade de dados é elevada, a tabela com as respectivas percentagens dos óxidos encontra-se em anexo (Tabela 5.1, 5.2 e 5.3).

Neste caso, analisando os óxidos dos macronutrientes de potássio (K), fósforo (P) e enxofre (S), notam-se variações muito interessantes no decorrer de apenas um ano. No gráfico da Figura 3.18, observa-se que nos canteiros onde houve o uso exclusivo de rochagem $(3,5,7$ e 9) ocorreu diminuição mais brusca nos teores destes nutrientes ao longo do ano se comparado aos canteiros onde houve rochagem e calagem (4, 6, 8 e 10). Este fato indica que o uso de calagem ainda que possa aumentar o $\mathrm{pH}$, diminui a disponibilidade e/ou a lixiviação destes nutrientes na forma solúvel.

Os canteiros com NPK ( 1 e 2) tiveram baixa variação ao longo do ano independente do uso de calagem. Por fim, o dolomito fosfatado (11) teve um pequeno decréscimo nos seus teores e o Latossolo controle (12) manteve-se praticamente constante.

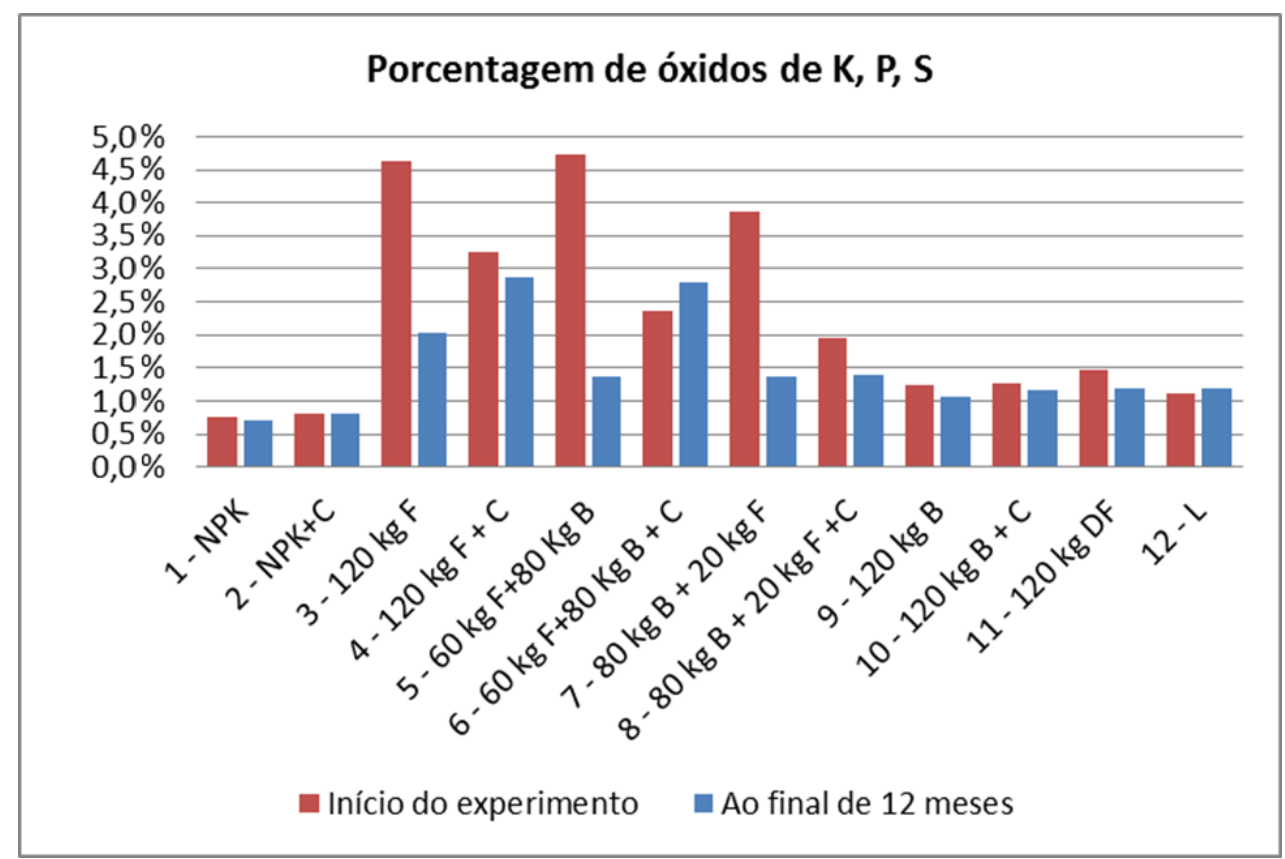

Figura 3. 18 - Gráfico com os teores dos óxidos de K, P e S. Em vermelho estão os teores iniciais da aplicação e em azul após um ano da plantação. Nesta figura é notável que nas parcelas onde não se aplicpou calagem, os teores dos elementos apresentaram uma diminuição mais brusca que os com calagem. Este fato indica que a utilização de calagem sem rochagem pode disponibilizar e/ou lixiviar de forma mais rápida os nutrientes se comparado com as porções com rochagem e calagem.

Conclusões semelhantes também são obtidas em relação aos micronutrientes como Ni, $\mathrm{Cu}, \mathrm{Zn}, \mathrm{Co}, \mathrm{MnO}$ como é demonstrado no gráfico da Figura 3.19. Isto reforça a impressão que o uso de calagem em conjunto com a rochagem diminui a disponibilidade de nutrientes e/ou diminui a lixiviação se comparado com o uso exclusivo de rochagem. 


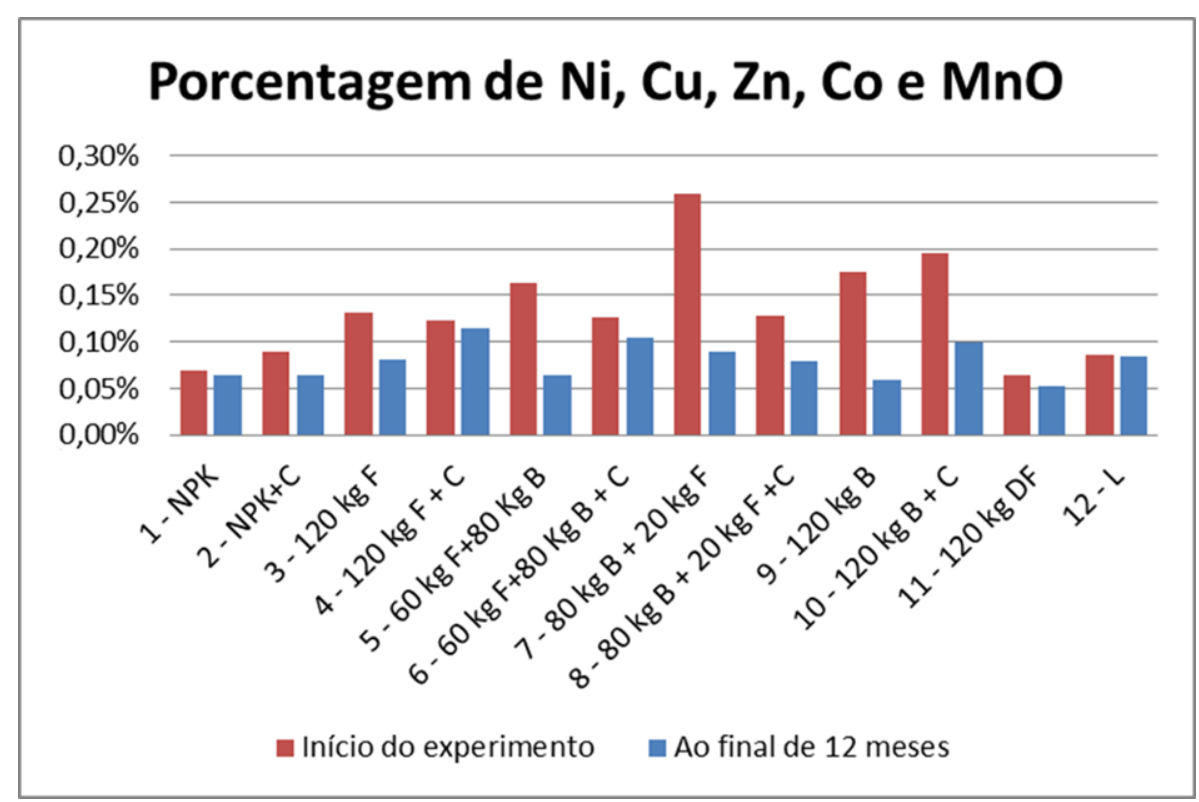

Figura 3. 19 - Gráfico com alguns micronutrientes importantes para as plantas. Em vermelho estão os teores iniciais dos nutrientes e em azul após um ano da aplicação. Notar que esta variação é menos acentuada nos canteiros onde houve o uso de calagem e rochagem se comparado com os canteiros com uso exclusivo de rochagem. Isto reforça a ideia de que a calagem pode diminuir a disponibilidade de nutrientes solúveis liberados pelos pós de rocha.

Por fim, baseado nas três análises no decorrer do ano, foi possível construir o gráfico da Figura 3.20 com os teores dos macronutrientes potássio, enxofre e fósforo dos canteiros sem calagem de basalto e/ou fosforito (3, 5, 7 e 9) e dolomito fosfatado (11). Neste gráfico é possível verificar a gradual diminuição destes elementos na forma sólida (provavelmente insolúvel), e consequentemente, a liberação destes macronutrientes para o sistema.

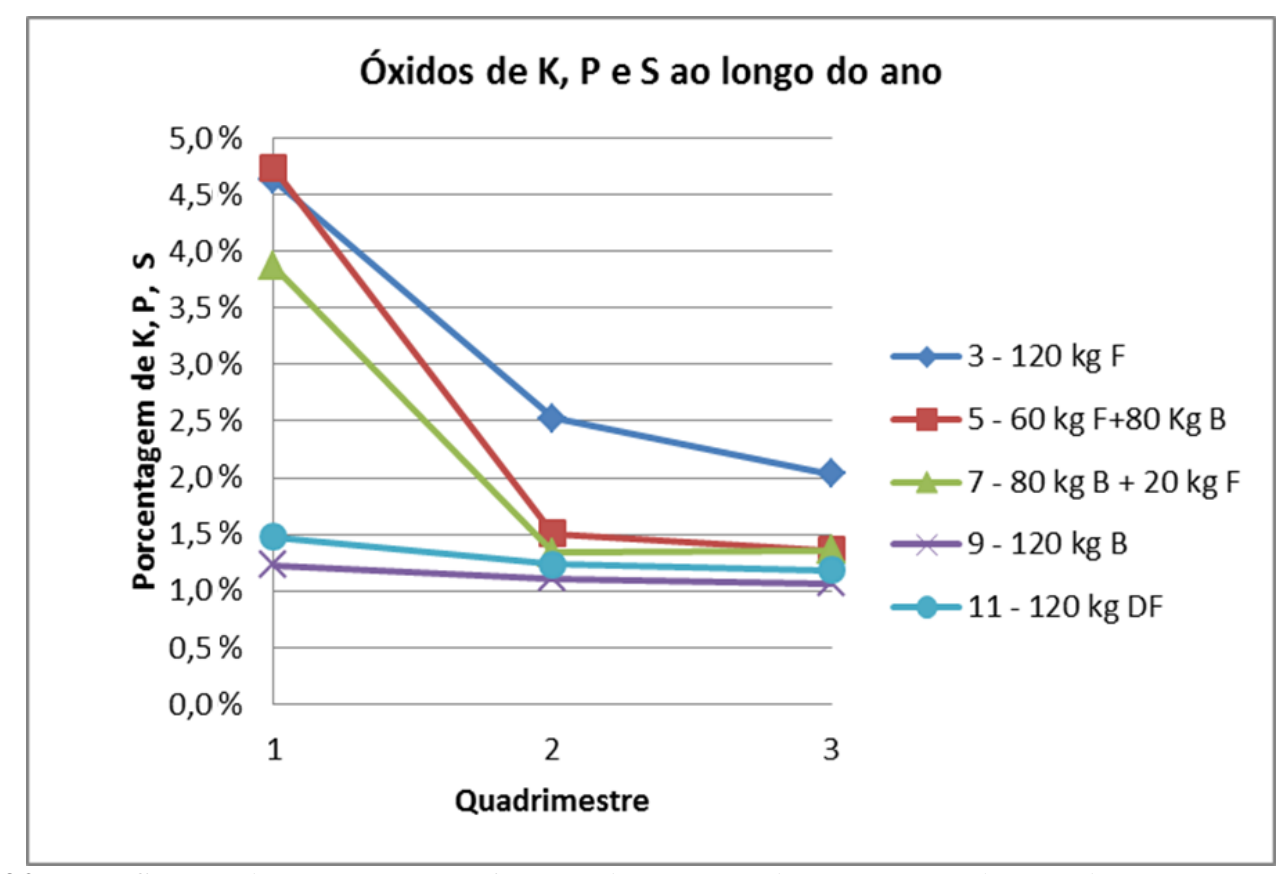

Figura 3. 20 - Gráfico onde mostra as variações dos teores de $\mathrm{K}, \mathrm{P}, \mathrm{S}$ ao longo do ano em canteiros com o uso exclusivo de rochagem (3, 5, 7, 9 e 11). Notar que em todos os canteiros analisados houve uma diminuição gradual dos teores ao longo dos quadrimestres. Isto provavelmente reflete em uma maior disponibilidade destes nutrientes para as plantas ou uma maior lixiviação. 


\subsubsection{Geoquímica de Fertilidade do Solo Após um Ano de Plantio}

Os dados de geoquímica de solo, para os doze canteiros analisados após um ano de plantio, podem ser analisados na Tabela 3.4. Em uma sucinta análise nota-se que o uso de insumos oriundos da rochagem, de maneira geral, aumentam a saturação por bases, o pH, e o P disponível (Figura 3.21). Ainda diminuem drasticamente a saturação por alumínio. Entretanto, parâmetros como matéria orgânica e carbono tiveram, em sua maioria, menores teores provavelmente devido ao aumento da atividade microbiana (Figura 3.22).

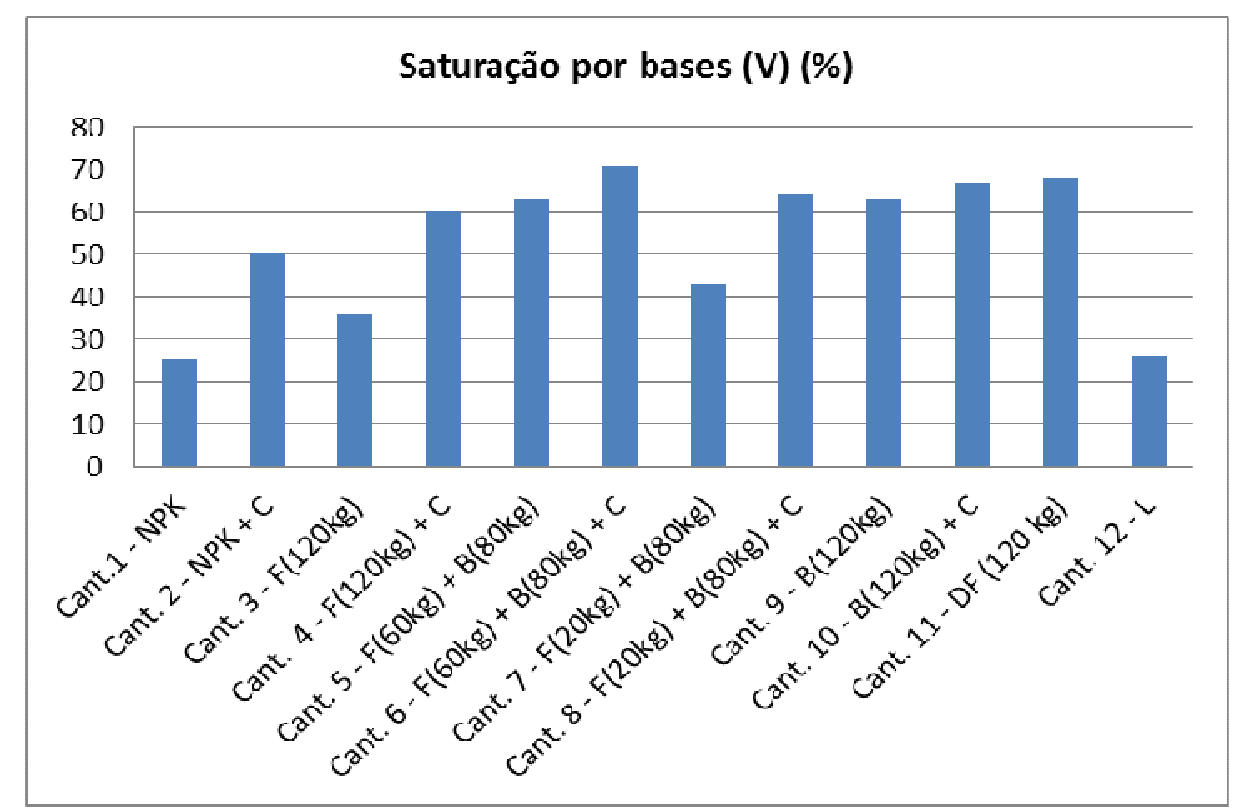

Figura 3. 21 - Neste gráfico é evidente que onde ocorreu a aplicação de insumos, especialmente ligados a rochagem e ao NPK com calagem, houve acréscimo de saturação por bases se comparado com o Latossolo controle (canteiro 12).

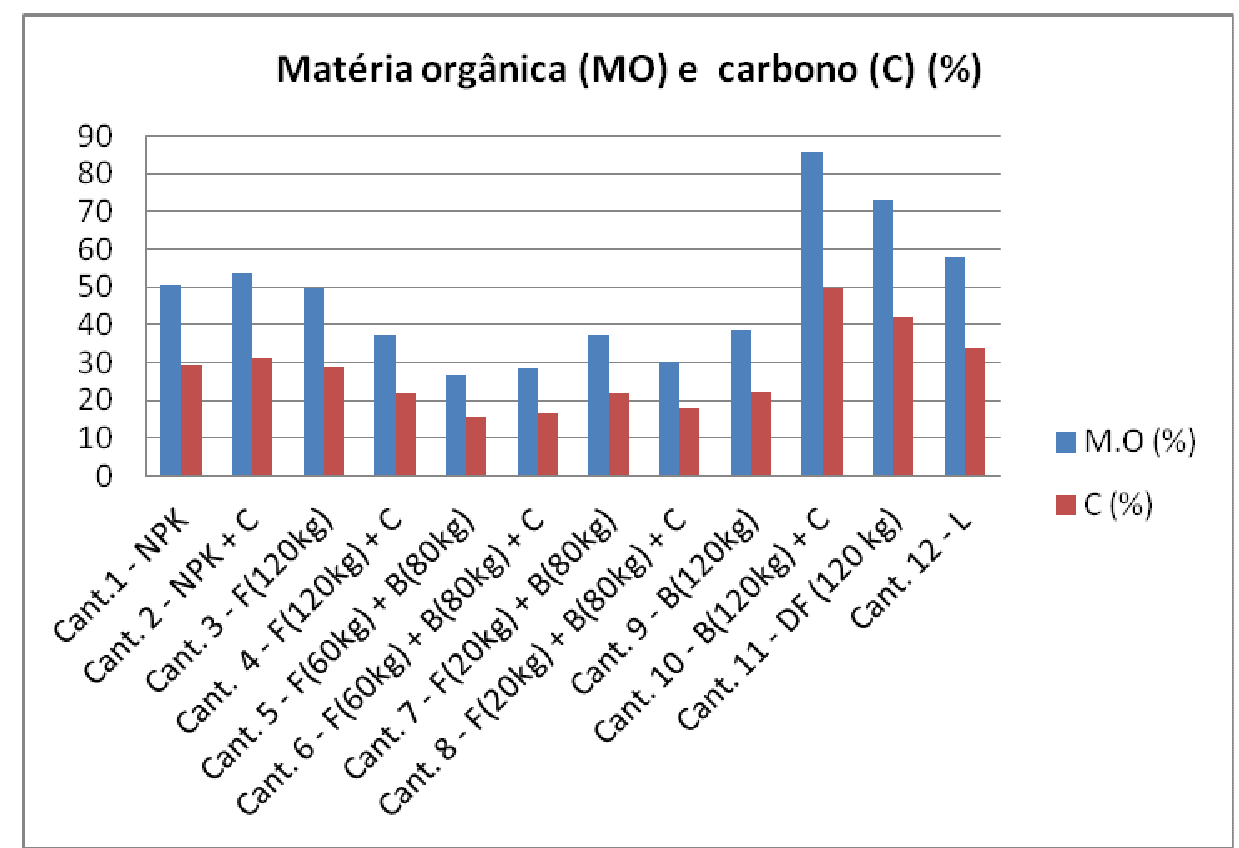

Figura 3. 22 - Gráfico onde se verifica que a utilização dos insumos de maneira geral, diminuem a quantidade de matéria orgânica (M.O) e carbono (C) se comparado com o Latossolo controle. A exceção fica para os canteiros 10 e 11. Isto ocorre possivelmente pelo aumento da atividade microbiana. 
Neste estudo, para facilitar a comparação das diferentes misturas e aplicações de fertilizantes, foram divididos em seis grupos principais, sendo eles: Latossolo controle; rochagem sem calagem; rochagem com calagem; dolomito fosfatado; NPK com calagem e NPK sem calagem.

Tabela 3. 4 - Análise de fertilidade do solo para os doze canteiros do experimento. Onde $\mathrm{C}=\mathrm{Calagem}$; $\mathrm{F}$ $=$ Fosforito $; \mathrm{B}=$ Basalto; $\mathrm{DF}=$ Dolomito fosfatado; $\mathrm{L}=$ Latossolo.

\begin{tabular}{|c|c|c|c|c|c|c|c|c|c|c|c|c|c|c|c|}
\hline \multirow{2}{*}{ Tratamento } & \multicolumn{6}{|c|}{ Complexo o } & \multicolumn{3}{|c|}{ Valor } & \multicolumn{2}{|c|}{ Sat. } & \multirow{3}{*}{$\frac{\mathbf{p H}}{\mathrm{H}_{2} \mathrm{O}}$} & \multirow{2}{*}{$\begin{array}{l}\text { P. Disp. } \\
\text { Mehlich }\end{array}$} & \multicolumn{2}{|c|}{\begin{tabular}{l|l} 
M.O & C \\
\end{tabular}} \\
\hline & $\mathrm{Ca}^{2+}$ & $\mathrm{Mg}^{2+}$ & $\mathrm{K}^{+}$ & $\mathrm{Na}^{+}$ & $\mathrm{Al}^{3}$ & $\begin{array}{c}\mathrm{Al} \\
+\mathrm{H} \\
\end{array}$ & S B & CTC & $\mathrm{V}$ & $\mathrm{Al}$ & $\mathrm{Na}$ & & & & \\
\hline & & & & $\mathrm{cmo}$ & $\mathrm{dm}^{3}$ & & & & & $\%$ & & & $\mathrm{mg} / \mathrm{dm}^{3}$ & & \\
\hline 1. NPK & 0,6 & 0,5 & 0,05 & 0,16 & 0,3 & 4,0 & 1,31 & 5,31 & 25 & 19 & 3 & 5,4 & 1,9 & 50,6 & 29,4 \\
\hline 2. $\mathrm{NPK}+\mathrm{C}$ & 1,2 & 0,4 & 0,06 & 0,14 & 0,0 & 1,8 & 1,80 & 3,6 & 50 & 0 & 4 & 6,4 & 1,8 & 53,6 & 31,2 \\
\hline 3. $F(120 \mathrm{~kg})$ & 1,0 & 0,4 & 0,06 & 0,20 & 0,0 & 3,0 & 1,66 & 4,66 & 36 & ( & 4,4 & 5,9 & 4,8 & 49,6 & 28,8 \\
\hline 4. $F(120 \mathrm{~kg})+C$ & 2,0 & 0,4 & 0,24 & 0,40 & 0,0 & 2,0 & 3,03 & 5,03 & 60 & 0 & 7,9 & 6,7 & 3,8 & 37,2 & 21,6 \\
\hline $\begin{array}{l}\text { 5. } \quad \mathrm{F}(60 \mathrm{~kg})+ \\
\mathrm{B}(80 \mathrm{~kg})\end{array}$ & 2,6 & 0,3 & 0,14 & 0,65 & 0,0 & 2,2 & 3,69 & 5,89 & 63 & 0 & 11 & 6,7 & 6,0 & 26,8 & 15,6 \\
\hline $\begin{array}{l}\text { 6. F(60kg) } \\
B(80 \mathrm{~kg})+C\end{array}$ & 2,2 & 0,6 & 0,17 & 0,94 & 0,0 & 1,6 & 3,91 & 5,51 & 71 & 0 & 17,1 & 7,3 & 3,2 & 28,3 & 16,5 \\
\hline $\begin{array}{l}\text { 7. } \quad F(20 \mathrm{~kg})+ \\
\mathrm{B}(80 \mathrm{~kg})\end{array}$ & 1,7 & 0,3 & 0,09 & 0,14 & 0,2 & 3,0 & 2,23 & 5,23 & 43 & 8 & 2,7 & 6,6 & 2,2 & 37,4 & 21,8 \\
\hline $\begin{array}{l}8 . \quad F(20 \mathrm{~kg}) \\
\mathrm{B}(80 \mathrm{~kg})+\mathrm{C}\end{array}$ & 2,0 & 0,5 & 0,34 & 0,39 & 0,0 & 1,8 & 3,23 & 5,03 & 64 & 0 & 7,8 & 7,0 & 1,7 & 30,3 & $\overline{17,6}$ \\
\hline 9. $B(120 \mathrm{~kg})$ & 2,1 & 0,8 & 0,09 & 0,28 & 0,0 & 1,9 & 3,27 & 5,17 & 63 & 0 & 5,4 & 7,0 & 1,7 & 38,4 & 22,3 \\
\hline $\begin{array}{l}\text { 10. } B(120 \mathrm{~kg})+ \\
\mathrm{C}\end{array}$ & 2,5 & 0,5 & 0,14 & 0,57 & 0,0 & 1,8 & 3,71 & 5,51 & 67 & 0 & 10,4 & 7,0 & 12,1 & 85,7 & 49,8 \\
\hline 11. DF $(120 \mathrm{~kg})$ & 2,1 & 0,9 & 0,09 & 0,23 & 0,0 & 1,6 & 3,32 & 4,92 & 68 & 0 & 4,7 & 7,1 & 1,0 & 72,8 & 42,3 \\
\hline 12. L & 0,7 & 0,6 & 0,13 & 0,16 & 0,2 & 4,6 & 1,59 & 6,19 & 26 & 11 & 2,5 & 5,6 & 3,2 & 57,9 & 33,7 \\
\hline
\end{tabular}

O Latossolo controle (canteiro 12) ao fim de um ano de análise se comparado com o solo inicial apresenta propriedades semelhantes (Tabela 3.3 e 3.4), sendo distrófico com saturação por bases de $26 \%$ e pH levemente ácido de 5,6, possui saturação por alumínio relativamente baixa e teores de M.O e carbono moderados, respectivamente de $57,9 \mathrm{~g} / \mathrm{kg}$ e $33,7 \mathrm{~g} / \mathrm{kg}$.

O uso de rochagem sem calagem (canteiros 3, 5, 7, 9), apresentou significativo acréscimo de saturação por bases se comparado ao Latossolo controle com variação de $36 \%$ a $63 \%$ e média de 51,25\%. Esta média, em conjunto com um pH variando de 5,9 a 7 indicam caráter eutrófico e adequado a alto para o solos típicos do cerrado (Sousa \& Lobato 2004 e Ronquim 2010). Neste caso, é interessante notar que o uso exclusivo de fosfato (canteiro 3) apresentou valores mais baixos de saturação por bases (36\%), seguido pela mistura de basalto e fosfato (canteiro 7). Os maiores valores encontram-se no uso exclusivo de basalto (canteiro 9) e da mistura de maior quantidade de fosfato com basalto (canteiro 5) ambos com $63 \%$.

Numa rápida avaliação, pode-se inferir que o uso exclusivo do basalto, pode aumentar significativamente a presença de cátions fundamentais ao desenvolvimento da planta especialmente do $\mathrm{Ca}^{2+}$. Ainda, o uso exclusivo de fosforito, não resultou em um aumento significativo da saturação por bases, ficando levemente superior ao do Latossolo controle que é de $26 \%$. 
Com relação à saturação por alumínio, a única parcela que não apresentou valor nulo foi a mistura de fosforito e basalto (canteiro 7) sendo o valor de $8 \%$ considerado baixo. Neste estudo, notou-se que os valores de matéria orgânica (M.O) (26,8 g/kg a 49,6 g/kg) e carbono (C) $(15,6 \mathrm{~g} / \mathrm{kg}$ a $28,8 \mathrm{~g} / \mathrm{kg})$ diminuíram significativamente em relação ao Latossolo controle que exibe valores de M.O. e C, respectivamente, de 57,9 g/kg e 33,7 g/kg.

Por fim, analisando os macronutrientes $\mathrm{Na}^{+}, \mathrm{Ca}^{+}, \mathrm{Mg}^{2+}, \mathrm{K}^{+}$e fósforo (P) disponível, notase que apenas o magnésio e o potássio não apresentaram teores significativamente mais elevados com a aplicação dos pós de rocha. O cálcio é o elemento que aumentou de forma mais acentuada, variando de $1 \mathrm{cmol}_{\mathcal{c}} / \mathrm{dm}^{3}$ a $2,6 \mathrm{cmol}_{\mathcal{C}} / \mathrm{dm}^{3}$. O caráter solódico foi verificado nos canteiros 5 e 9 (IBGE 2007), provavelmente devido ao intemperismo do basalto e liberação do sódio contido em minerais como piroxênio e plagicoclásio. Já o fósforo disponível teve leve aumento nos canteiros com o uso majoritário de fosforito (3 e 5), com valores de $4,8 \mathrm{mg} / \mathrm{dm}^{3}$ e $6 \mathrm{mg} / \mathrm{dm}^{3}$ os quais ainda são considerados de baixo a médio segundo Sousa \& Lobato (2004).

A utilização de rochagem com calagem (canteiros $4,6,8,10$ ) apresentou os resultados de fertilidade significativos, com $\mathrm{pH}$ variando de $6,7 \mathrm{mg} / \mathrm{dm}^{3}$ a $7,3 \mathrm{mg} / \mathrm{dm}^{3}$ e saturação por bases de $60 \%$ a $71 \%$ sendo considerado eutrófico e alto para solos típicos do cerrado (Sousa \& Lobato 2004 e Ronquim 2010).

A saturação por alumínio foi nula em todas as parcelas. Já em relação ao $\mathrm{Na}$ os canteiros 4, 8 e 10 apresentaram caráter solódico variando de 7,8\% a 10,4\%, enquanto que a parcela número 6 possui caráter sódico $(17,1 \%)$.

Com relação ao macronutrientes, nota-se um significativo aumento $\mathrm{de} \mathrm{Ca}^{+}\left(2 \mathrm{cmol}_{\mathrm{c}} / \mathrm{dm}^{3}\right.$ a $\left.2,5 \mathrm{cmol}_{\mathrm{c}} / \mathrm{dm}^{3}\right)$ e P disponível $\left(1,7 \mathrm{mg} / \mathrm{dm}^{3}\right.$ a $\left.12,1 \mathrm{mg} / \mathrm{dm}^{3}\right)$ em comparação com o Latossolo controle. Já os valores de $\mathrm{Mg}^{2+}$ e $\mathrm{K}^{+}$não apresentaram elevação de modo significativo. Em relação ao fósforo disponível é importante ressaltar que o maior valor foi encontrado no uso de basalto (canteiro 10) com valor de $12,1 \mathrm{mg} / \mathrm{dm}^{3}$. Já os demais canteiros onde se aplicou doses variadas de fosforito obtiveram teores de $1,7 \mathrm{mg} / \mathrm{dm}^{3}$ a $3,8 \mathrm{mg} / \mathrm{dm}^{3}$ os quais são relativamente mais baixos que a aplicação da rochagem sem calagem. Isto reforça a ideia de Ernani et al. (2001) que afirmam que o fosfato natural apresenta maior dissolução em condições de baixo pH.

$\mathrm{O}$ uso de dolomito fosfatado se assemelha bastante com a calagem convencional, com aumento importante de cálcio $\left(2,1 \mathrm{cmol}_{\mathrm{c}} / \mathrm{dm}^{3}\right)$ e suave de magnésio $\left(0,9 \mathrm{cmol}_{\mathrm{c}} / \mathrm{dm}^{3}\right)$ se comparado ao Latossolo controle. A saturação por alumínio é nula e por sódio é baixa $(4,7 \%)$. O pH é relativamente elevado $(7,1)$ juntamente com a matéria orgânica $(72,8 \mathrm{~g} / \mathrm{kg})$ e carbono $(42,3$ $\mathrm{g} / \mathrm{kg}$ ). Ainda que o caráter eutrófico seja elevado (68\%), isso se deve, essencialmente, pelos teores maiores de cálcio e magnésio. Já o $\mathrm{P}$ disponível e o $\mathrm{K}^{+}$possuem teores muito baixos, respectivamente, de $1 \mathrm{mg} / \mathrm{dm}^{3}$ e $0,09 \mathrm{cmol}_{\mathrm{c}} / \mathrm{dm}^{3}$ sendo inclusive menor que o do Latossolo controle. 
O uso do fertilizante solúvel (NPK) sem calagem apresentou os teores de nutrientes mais baixos em relação aos demais insumos aplicados. Apresenta, de modo geral teores iguais ou piores ao Latossolo controle, com pH levemente ácido $(5,4)$, caráter distrófico $(25 \%)$ e a saturação por alumínio (19\%) ainda que baixa segundo Sousa \& Lobato 2004 é a mais elevada entre os canteiros. Estes dados incidam que o uso exclusivo de fertilizante solúvel, além de não apresentar efeito residual significativo necessita, insubstituivelmente, do uso de calagem.

O fertilizante solúvel (NPK) com calagem, apresenta parâmetros melhores devido somente com o acréscimo do pó de calcário como a elevação do $\mathrm{pH}$ e $\mathrm{Ca}^{+}$resultando em um solo eutrófico (50\%). Esta parcela reforça a ideia do baixo efeito residual do NPK.

Por fim, se considerado o material inicial do processo de rochagem e o final, nota-se que no espaço de tempo de um ano, a solubilidade é ainda baixa e/ou a lixiviação é elevada. Isto é observado quando se compara $\mathrm{P}$ disponível após um ano nos canteiros com uso exclusivo de fosforito (3 e 4) que é de $6,35 \mathrm{mg} / \mathrm{dm}^{3}$ (extrador tipo melinch-1) já no fosforito brechado inicial é de $73.176,35 \mathrm{mg} / \mathrm{dm}^{3}$ para o extrador mehlich-1 e de $2.976,35 \mathrm{mg} / \mathrm{dm}^{3}$ para a resina trocadora de íons.

Ainda que valores de saturação por bases tenham diminuído em relação ao material inicial que é de $95 \%$ para o basalto, de $67 \%$ para o fosforito brechado e de $87 \%$ para o dolomito fosfatado, os teores médios após um ano de todos os insumos de rochagem com e sem calagem e dolomito fosfatado, estiveram em um valor expressivo de 59,4\%, caracterizando os solos como eutróficos. Isto reforça a ideia do efeito residual do uso de pó de rocha.

\subsection{Comportamento Eletroquímico}

Os Latossolos por apresentarem avançado estágio de intemperismo, possuem maior quantidade de cargas variáveis as quais dependem do $\mathrm{pH}$ do que de cargas permanentes as quais são originadas da substituição isomórfica no processo de formação mineral. Deste modo, o estudo das características das cargas deve ser baseado nas cargas variáveis, que são dependentes do $\mathrm{pH}$ do meio e derivadas especialmente da caulinita, sesquióxidos e matéria orgânica (Bolland et al. 1976, Anda et al. 2008, Machado et al. 2013). Assim sendo, para o melhor estudo das cargas variáveis, o trabalho analisou durante um ano medidas do $\mathrm{pH}$ em água e em $\mathrm{KCl}$.

A correção do $\mathrm{pH}$ do solo é essencial para um plantio eficiente, visto que aumenta a disponibilidade de fósforo, promove um aumento da atividade microbiana e reduz a toxicidade do alumínio e manganês, além de ter efeito positivo na adsorção dos nutrientes (Ernani et al. 1996 e 1998). Entretanto, essa correção pode aumentar a dispersão da argila, que causa diminuição da estabilidade dos agregados, selamento da superfície do solo, redução da infiltração da água, consequentemente aumentando a suceptibilidade a erosão (Roth \& Pavan 1991, Castro Filho \& Logan 1991, Albuquerque et al. 2000 e Tavares Filho et al. 2010). 
O aumento da dispersão é especialmente correlacionado com a alteração na espessura da dupla camada elétrica (DCE) do solo, sendo a magnitude dessa alteração o resultado de efeitos antagônicos provocados pela calagem: o aumento das cargas elétricas negativas e a substituição de íons trivalentes por divalentes no complexo de troca tende a aumentar a DCE, e por outro

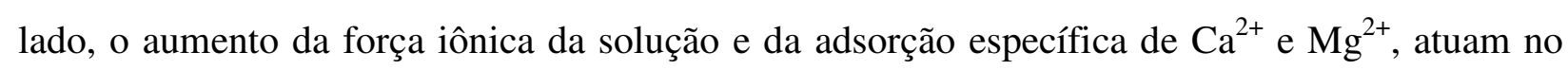
sentido inverso (Sposito 1989, Charlet \& Sposito 1989 e Albuquerque, 2000).

A superfície elétrica potencial é proporcional a diferença entre o $\mathrm{pH}$ e o ponto zero de carga (PCZ), o qual corresponde ao valor de $\mathrm{pH}$ onde a carga variável líquida é zero na superfície das cargas variáveis (Sposito 1989 e Tavares Filho et al. 2010).

Assim, se o pH do solo está acima do PCZ, a superfície do solo apresenta carga líquida negativa, e apresentará maior habilidade para trocar cátions (CTC), entretanto, se o pH está abaixo do PCZ o solo terá mais facilidade de manter ânions (Appel et al. 2003).

No trabalho, foram realizadas medições do $\mathrm{pH}$ em $\mathrm{H}_{2} \mathrm{O}$ e em $\mathrm{KCl}$ mensalmente durante o período de um ano os quais foram agrupados de forma trimestral. Os valores de $\Delta \mathrm{pH}$ e PCZ foram calculados pela Equação 2.1 .

Equação 2.1 - Para o melhor entendimento do equilíbrio de cargas no solo é fundamental o entendimento da variação do $\mathrm{pH}$ e do potencial de carga zero.

\begin{tabular}{|l|c|}
\hline Equação de variação do $\mathrm{pH}$ & $\begin{array}{c}\Delta \mathrm{pH}=p H . \mathrm{KCl}-\mathrm{pH} . \mathrm{H} 2 \mathrm{O} \\
(\text { Mekarh \& Uehora } 1972)\end{array}$ \\
\hline Equação do potencial de carga zero & $\mathrm{PCZ}=2 \mathrm{pH} . \mathbf{K C l}-\mathrm{pH} . \mathrm{H}_{2} \mathrm{O}$ \\
& $($ Keng \& Uehara, 1974) \\
\hline
\end{tabular}

No presente estudo a média anual das medições do $\mathrm{pH}$ em $\mathrm{H}_{2} \mathrm{O}$ e em $\mathrm{KCl}$ estão sintetizadas na Tabela 3.5. Onde se observa na esfera da rochagem que o basalto juntamente com o dolomito fosfatado tiveram maior importância no controle do pH em comparação com o fosforito. Já o uso exclusivo do NPK se mostrou insignificante para regularizar o $\mathrm{pH}$, sendo necessário o uso de calagem.

Para facilitar o estudo, as análises foram agrupadas em seis grupos visualizados na Tabela 3.6 onde se observa: Rochagem sem calagem (Canteiros 3, 5, 7, 9); Rochagem com calagem; (Canteiros 4, 6, 8, 10); NPK sem Calagem (Canteiro 1); NPK com Calagem (Canteiro 2); Latossolo (Canteiro 12) e Dolomito fosfatado (Canteiro 11). 
Tabela 3. 5 - Média anual do $\mathrm{pH}$ em $\mathrm{H}_{2} \mathrm{O}$ e $\mathrm{KCl}$ para os 12 canteiros estudados. Notar que no âmbito da rochagem, o basalto (B) juntamente com o dolomito fosfatado (DF) tiveram maior importância no controle do $\mathrm{pH}$ em comparação com o fosforito (F). Por fim, o uso exclusivo do NPK se mostrou insignificante para regularizar o $\mathrm{pH}$, sendo necessário o uso de calagem (C).

\begin{tabular}{|l|c|c|}
\hline & \multicolumn{2}{|c|}{ Média Anual } \\
\hline Canteiros & $\mathrm{pH} \mathrm{em} \mathrm{H}_{2} \mathrm{O}$ & $\mathrm{pH} \mathrm{em} \mathrm{KCl}$ \\
\hline NPK & 5,34 & 4,58 \\
\hline $\mathrm{NPK}+\mathrm{C}$ & 6,24 & 5,87 \\
\hline $120 \mathrm{~kg} \mathrm{~F}$ & 5,84 & 5,12 \\
\hline $120 \mathrm{~kg} \mathrm{~F}+\mathrm{C}$ & 6,24 & 5,86 \\
\hline $60 \mathrm{~kg} \mathrm{~F}+80 \mathrm{Kg} \mathrm{B}$ & 6,14 & 5,15 \\
\hline $60 \mathrm{~kg} \mathrm{~F}+80 \mathrm{Kg} \mathrm{B}+\mathrm{C}$ & 6,40 & 6,12 \\
\hline $80 \mathrm{~kg} \mathrm{~B}+20 \mathrm{~kg} \mathrm{~F}$ & 6,43 & 4,97 \\
\hline $80 \mathrm{~kg} \mathrm{~B}+20 \mathrm{~kg} \mathrm{~F}+\mathrm{C}$ & 6,38 & 5,76 \\
\hline $120 \mathrm{~kg} \mathrm{~B}$ & 6,25 & 5,26 \\
\hline $120 \mathrm{~kg} \mathrm{~B}+\mathrm{C}$ & 6,31 & 5,79 \\
\hline $120 \mathrm{~kg} \mathrm{DF}$ & 6,72 & 6,58 \\
\hline Latossolo & 5,70 & 4,63 \\
\hline
\end{tabular}

As análises trimestrais do $\mathrm{pH}$ em $\mathrm{H}_{2} \mathrm{O}$ indicaram que as parcelas onde não houve calagem e nem rochagem, como o Latossolo controle e uso exclusivo do NPK, apresentaram os menores valores de $\mathrm{pH}$, com média anual, respectivamente de 5,70 e 5,34. Ainda que estes valores não sejam considerados muito ácidos fica claro que o uso somente do NPK não é suficiente para um aumento do $\mathrm{pH}$ (Tabela 3.6).

$\mathrm{O}$ uso de rochagem sem calagem, apresentou média anual de $\mathrm{pH}$ em $\mathrm{H}_{2} \mathrm{O}$ de 6,16 e a rochagem com calagem de 6,34 indicando valores semelhantes de correção de acidez (Tabela 3.6). Vale destacar que o dolomito fosfatado foi considerado em um grupo a parte e apresentou $\mathrm{pH}$ de 6,72 sendo o maior valor encontrado. Por fim, o NPK com calagem apresentou teores semelhantes aos anteriores com média anual de 6,24.

Tabela 3. 6 - Análise trimestral do $\mathrm{pH}$ em $\mathrm{H}_{2} \mathrm{O}$. Notar a média mais baixa para o NPK sem calagem e o Latossolo controle. Os valores maiores são, em ordem crescente, da rochagem sem calagem; NPK com calagem; rochagem com calagem e dolomito fosfatado.

\begin{tabular}{|l|c|c|c|c|c|}
\hline $\begin{array}{l}\text { Período do ano (trimestral) - pH em } \\
\mathbf{H}_{2} \mathbf{O}\end{array}$ & $\mathbf{1}^{\mathbf{a}}$ & $\mathbf{2}^{\mathbf{a}}$ & $\mathbf{3}^{\mathbf{a}}$ & $\mathbf{4}^{\mathbf{a}}$ & $\begin{array}{c}\text { Média } \\
\text { anual }\end{array}$ \\
\hline Rochagem S/ calagem (Canteiros 3, 5, 7,9) & 6,35 & 5,88 & 5,79 & 6,64 & 6,16 \\
\hline Rochagem C/ calagem (Canteiros 4, 6,8,10) & 6,30 & 5,88 & 6,59 & 6,57 & 6,34 \\
\hline NPK S/ Calagem (Canteiro 1) & 5,82 & 4,89 & 4,97 & 5,69 & 5,34 \\
\hline NPK C/ Calagem (Canteiro 2) & 5,97 & 5,47 & 6,61 & 6,9 & 6,24 \\
\hline Latossolo (Canteiro 12) & 6,80 & 5,195 & 5,10 & 5,70 & 5,70 \\
\hline Dolomito fosfatado (Canteiro 11) & 6,70 & 6,33 & 6,89 & 6,96 & 6,72 \\
\hline
\end{tabular}


Ainda que a oscilação trimestral seja um período relativamente curto de tempo para analisar a variação do $\mathrm{pH}$, uma análise em gráfico linear, indica que as amostras com uso de rochagem (com ou sem calagem), NPK com calagem e dolomito fosfatado apresentam um leve aumento no valor de $\mathrm{pH}$ no período final do ano, sugerindo a permanência do fator corretivo do solo (Figura 3.23). Já o uso exclusivo do NPK sem calagem bem como o Latossolo de controle, mostram a ocorrência de valores mais baixos de pH (Figura 3.23).

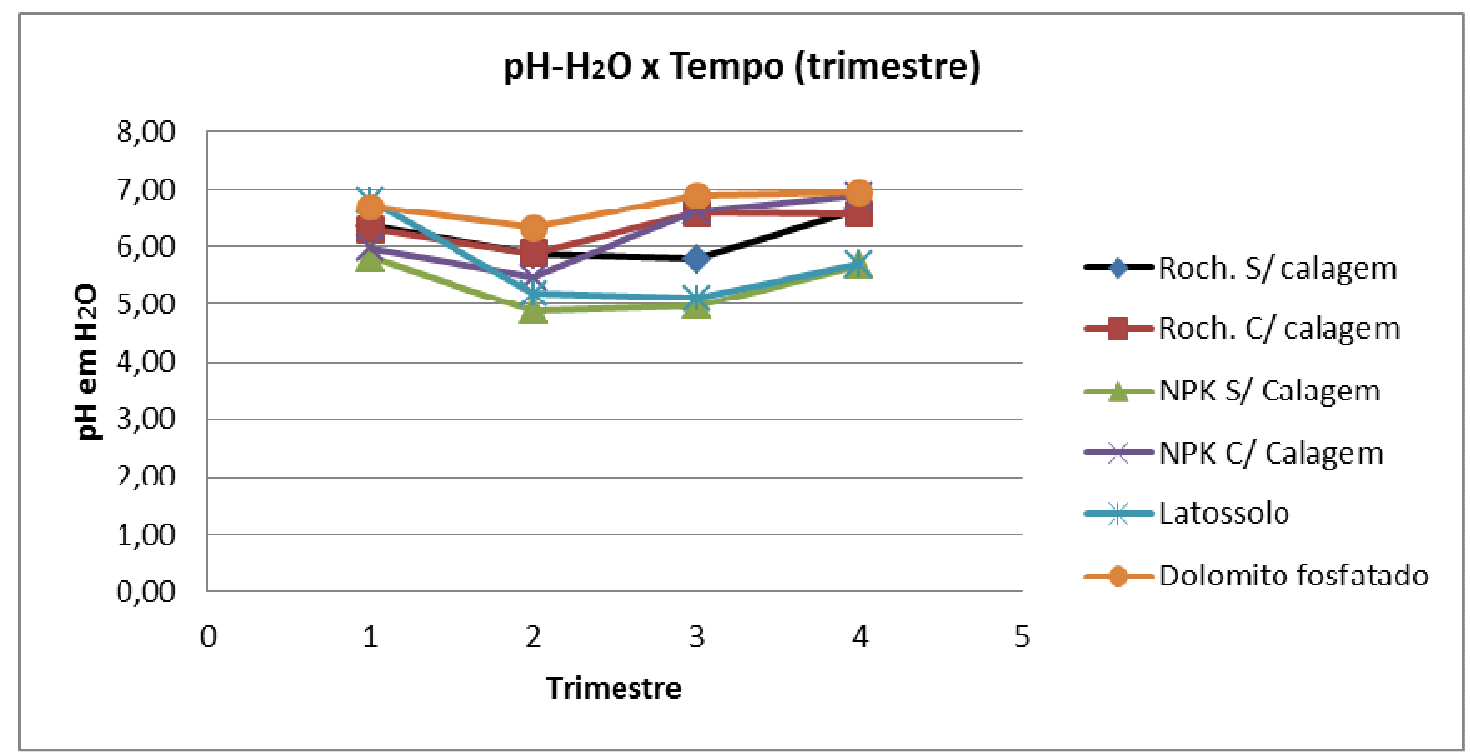

Figura 3. 23 - Gráfico de $\mathrm{pH}$ em água versus tempo (trimestral). Notar uma leve tendência ao aumento no valor do $\mathrm{pH}$ relacionado as áreas onde ocorreu a aplicação de insumos como a calagem e a rochagem.

Os valores de $\mathrm{pH}$ em $\mathrm{KCl}$ mostram uma relação mais clara entre o uso dos diferentes insumos e a elevação do pH (Tavares Filho et al. 2010).

Os resultados mostram uma diferença significativa da aplicação dos insumos com ou sem o uso de calagem (Tabela 3.7). O valor médio anual do pH em KCL com uso exclusivo de rochagem, ainda que possua uma média de 5,12, fica abaixo das áreas onde se usa a calagem associado ao NPK $(5,88)$, ou associada a própria rochagem $(5,87)$.

O uso de dolomito fosfatado é o que apresenta maior valor anual de pH em KCL de 6,58. Já os menores valores são do uso exclusivo do NPK $(4,58)$ e do Latossolo controle $(4,63)$. 
Tabela 3. 7 - Dados de pH em KCL em relação ao tempo trimestral. Notar a elevada influência da calagem no aumento do $\mathrm{pH}$.

\begin{tabular}{|l|c|c|c|c|c|}
\hline $\begin{array}{l}\text { Período do ano (trimestral) - } \mathbf{~ p H ~ e m ~} \\
\text { KCl }\end{array}$ & $\mathbf{1}^{\mathbf{a}}$ & $\mathbf{2}^{\mathbf{a}}$ & $\mathbf{3}^{\mathbf{a}}$ & $\mathbf{4}^{\mathbf{a}}$ & $\begin{array}{l}\text { Média } \\
\text { anual }\end{array}$ \\
\hline Rochagem S/ calagem (Canteiros 3, 5, 7,9) & 5,38 & 4,96 & 4,85 & 5,30 & 5,12 \\
\hline Rochagem C/ calagem (Canteiros 4, 6, 8, 10) & 5,78 & 5,36 & 6,09 & 6,30 & 5,88 \\
\hline NPK S/ Calagem (Canteiro 1) & 4,81 & 4,37 & 4,50 & 4,63 & 4,58 \\
\hline NPK C/ Calagem (Canteiro 2) & 5,63 & 5,18 & 6,20 & 6,47 & 5,87 \\
\hline Latossolo (Canteiro 12) & 4,86 & 4,74 & 4,36 & 4,55 & 4,63 \\
\hline Dolomito fosfatado (Canteiro 11) & 6,57 & 6,17 & 6,78 & 6,81 & 6,58 \\
\hline
\end{tabular}

O gráfico da Figura 3.24 mostra que no decorrer dos quatro trimestres analisados o uso da calagem é bastante importante para o controle do $\mathrm{pH}$ em $\mathrm{KCl}$, sendo que o uso único da rochagem ainda que tenha poder corretivo, necessita de alta tonelagem para ser efetiva. Vale ressaltar que o dolomito fosfatado apresenta alto poder regulador o qual permaneceu constante durante o período em análise.

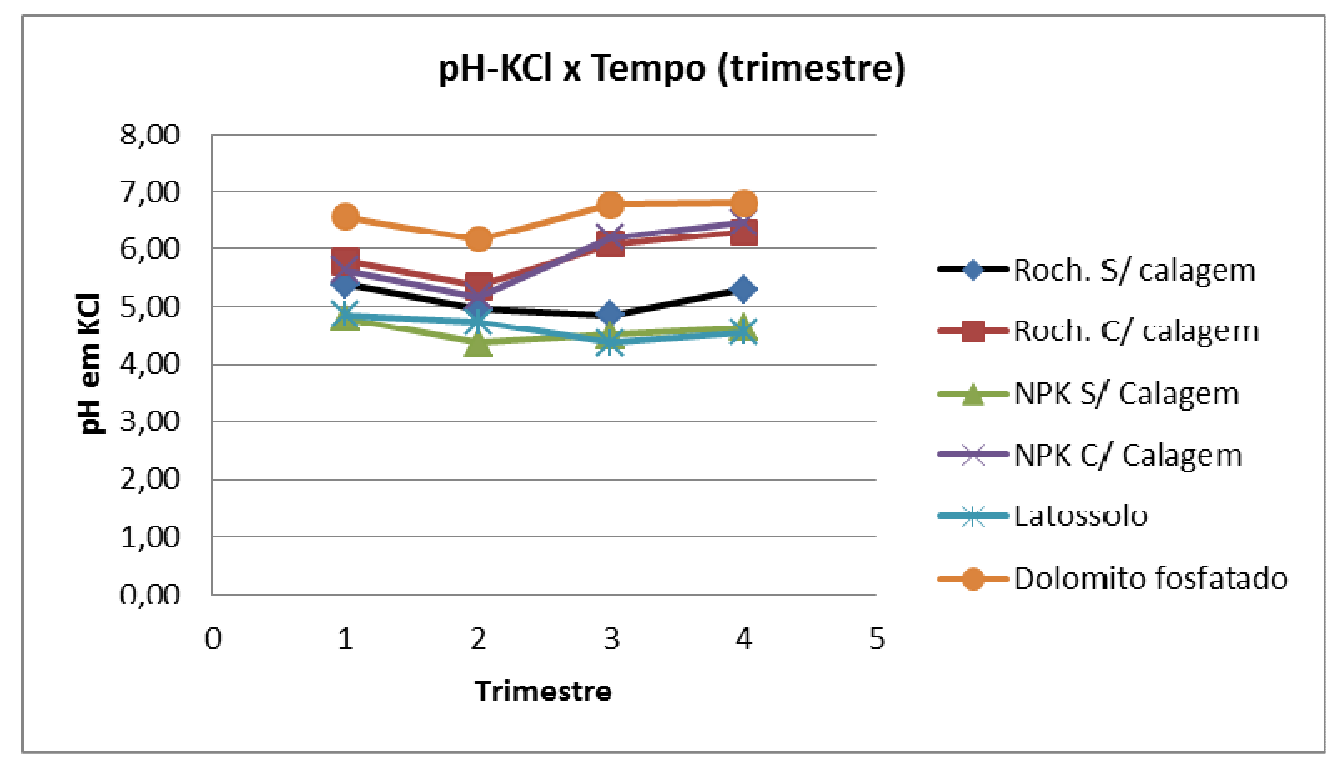

Figura 3.24 - Gráfico pH em $\mathrm{KCl}$ versus tempo (trimestral). Notar a importância do uso da calagem no controle do $\mathrm{pH}$. Vale ressaltar o elevado poder corretivo do dolomito fosfatado.

Os valores de $\Delta \mathrm{pH}$ foram sempre negativos, indicando que a carga líquida é negativa para todos os tratamentos o que favorece o aumento da CTC (Tabela 3.8).

O ponto de carga zero (PCZ) do Latossolo de 3,55 está nos limites obtidos por Magalhães \& Page (1984) em Latossolos (3,6 a 4,6). Analisando a Tabela 3.8 fica evidente que o uso do pó de rocha bem como a calagem aumentou o PCZ do solo. 
Tabela 3. 8 - Tabela indicando a variação do delta $\mathrm{pH}(\Delta \mathrm{pH})$ e do ponto de carga zero (PCZ) ao longo do ano.

\begin{tabular}{|l|r|r|r|r|r|r|r|r|r|r|}
\hline $\begin{array}{l}\text { Período do ano } \\
\text { (trimestral) }\end{array}$ & \multicolumn{2}{|c|}{$1^{\text {a }}$} & \multicolumn{2}{|c|}{$2^{\mathbf{a}^{-}}$} & \multicolumn{2}{c|}{$3^{\text {a }}$} & \multicolumn{3}{|c|}{$4^{\text {a }}$} & \multicolumn{2}{c|}{ Média anual } \\
\hline & $\mathbf{\Delta} \mathbf{p H}$ & $\mathbf{P C Z}$ & $\mathbf{\Delta} \mathbf{p H}$ & $\mathbf{P C Z}$ & $\mathbf{\Delta} \mathbf{p H}$ & $\mathbf{P C Z}$ & $\mathbf{\Delta} \mathbf{p H}$ & $\mathbf{P C Z}$ & $\mathbf{\Delta} \mathbf{p H}$ & $\mathbf{P C Z}$ \\
\hline Roch. S/ calagem & $-0,97$ & 4,42 & $-0,91$ & 4,05 & $-0,93$ & 3,92 & $-1,34$ & 3,95 & $-1,04$ & 4,09 \\
\hline Roch. C/ calagem & $-0,52$ & 5,26 & $-0,52$ & 4,84 & $-0,49$ & 5,59 & $-0,27$ & 6,03 & $-0,45$ & 5,43 \\
\hline NPK S/ Calagem & $-1,01$ & 3,79 & $-0,52$ & 3,85 & $-0,47$ & 4,04 & $-1,06$ & 3,57 & $-0,77$ & 3,81 \\
\hline NPK C/ Calagem & $-0,34$ & 5,28 & $-0,30$ & 4,88 & $-0,40$ & 5,80 & $-0,43$ & 6,03 & $-0,37$ & 5,50 \\
\hline Latossolo & $-1,94$ & 2,91 & $-0,46$ & 4,28 & $-0,74$ & 3,61 & $-1,15$ & 3,41 & $-1,07$ & 3,55 \\
\hline $\begin{array}{l}\text { Dolomito } \\
\text { fosfatado }\end{array}$ & $-0,13$ & 6,44 & $-0,17$ & 6,00 & $-0,11$ & 6,67 & $-0,15$ & 6,66 & $-0,14$ & 6,44 \\
\hline
\end{tabular}

Ainda que a calagem seja um importante fator no aumento da PCZ $(5,43$ a 5,50), o uso exclusivo de dolomito fosfatado teve grande poder de aumento do potencial $(6,44)$. Já o uso exclusivo de pó de rocha, aumentou de maneira mais suave esses valores $(4,09)$. Vale lembrar que o Latossolo controle e o NPK sem calagem apresentaram os menores valores, respectivamente, de 3,55 e 3,81. O gráfico da Figura 3.25 evidencia que as áreas com o uso da calagem ou do dolomito fosfatado tiveram uma pequena elevação do PCZ ao longo do ano. Enquanto que áreas somente com rochagem ou NPK apresentaram leve declínio.

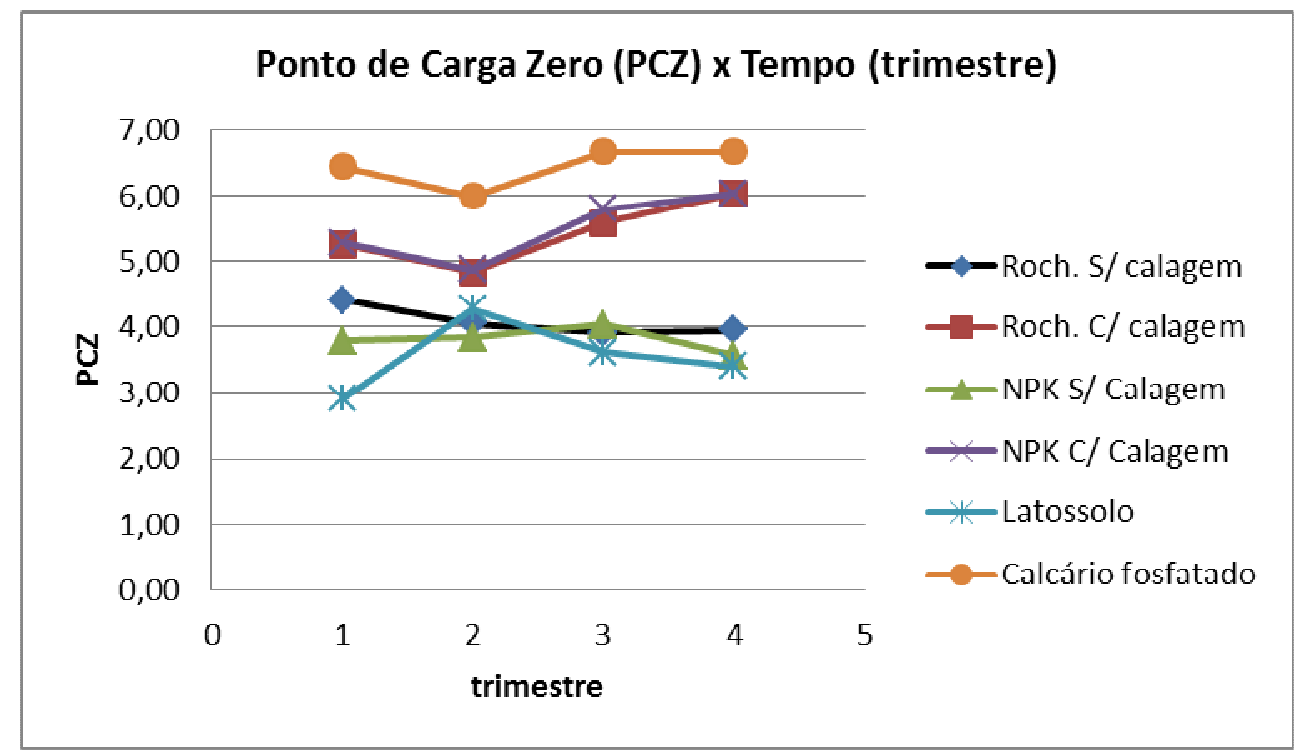

Figura 3. 25 - O gráfico do potencial de carga zero (PCZ) versus tempo (trimestral) onde se sugere que as áreas com o uso da calagem ou do dolomito fosfatado tiveram uma pequena elevação do PCZ ao longo do ano. Enquanto que áreas somente com rochagem ou NPK apresentaram leve declínio.

Os valores mais elevados de PCZ devem-se, provavelmente, a diminuição dos teores de matéria orgânica (aumento da atividade microbiana) e a adsorção específica de $\mathrm{Ca}^{2+}{\mathrm{e} \mathrm{Mg}^{2+}}^{\mathrm{os}}$ quais incorporam cargas positivas às superfícies sólidas do solo, diminuindo com isso a carga líquida negativa (Charlet \& Sposito 1989 e Albuquerque 2000). A redução da matéria orgânica 
ocasiona a diminuição do número de grupos carboxílicos, que são os principais responsáveis pelas cargas negativas da matéria orgânica (Schnitzer 1986) e a diminuição na adsorção específica de ânions orgânicos (Oades et al. 1989).

Uma das vantagens do uso de silicatos ao invés somente da calagem é relacionado com a maior disponibilidade de fósforo. Isto ocorre, pois o uso de silicatos pode tornar o ânion silicato $\left(\mathrm{H}_{3} \mathrm{SiO}^{-}\right)$disponível, que concorre com o ânion fosfato pelo mesmo sítio de adsorção, saturando dessa forma o ponto onde possivelmente seria adsorvido o fósforo (Sandim et al. 2014). Assim sendo, a correção da acidez do solo com silicatos, além de elevar o $\mathrm{pH}$, pode disponibilizar o fósforo, pelo efeito adicional de deslocar o P adsorvido para a solução (Volkweiss \& Raij 1977). Além disso, o uso de fosfato natural apresenta maior dissolução do fosfato em condições de baixo pH (Ernani et al. 2001).

Por fim, como os valores de $\Delta \mathrm{pH}$ se aproximam mais de zero (Tabela 3.8), significa que as cargas estão mais equilibradas com uma menor dispersão de argila, pois estas são diretamente proporcionais ao número excessivo de cargas negativas.

Deste modo, o uso da rochagem, especialmente quando usado juntamente com a calagem em solos intemperizados pode aumentar a densidade das cargas negativas dos coloides, atraindo eletrostaticamente maior quantidade de âninos próximos a superfície dos coloides, diminuido a atividade de cargas negativas na solução do solo, consequentemente, ocorre aumento do PCZ (Raij \& Peech 1972, Tavares Filho et al. 2010 e Machado et al. 2013).

\subsection{Análise Mineralógica do Experimento Durante um Ano}

O estudo da análise mineralógica baseou-se na verificação durante um ano da difratometria de raios- $X$ em três etapas com o intuito de verificar a neoformação de minerais, especificados por Hawkes \& Webb (1962). O maior interesse é ligado a neoformação de minerais do tipo 2:1 os quais podem aumentar a CTC do solo bem como a capacidade de retenção de água e a diminuição da perda de nutrientes por lixiviação. Além disso, aumentam a resistência a mudança em pH, reduzindo a necessidade de calagem (Troxler 1999).

Os canteiros foram analisados individualmente, sendo os resultados de fração argila discutidos a seguir. As letras A B e C simbolizam, respectivamente, o primeiro, segundo e terceiro estágio os quais são separados por períodos de quatro meses.

Canteiro 1 (NPK): Como neste canteiro não foi aplicado pós de rocha, somente o uso de elementos solúveis para a planta, é natural que não ocorra variação mineralógica ao longo do ano. Isto é verificado na Figura 3.26 onde se nota uma mineralogia típica de Latossolo com gibbsita, quartzo, caulinita, goethita e rutilo. Notar a ausência de minerais importantes do ponto de vista agronômico. 


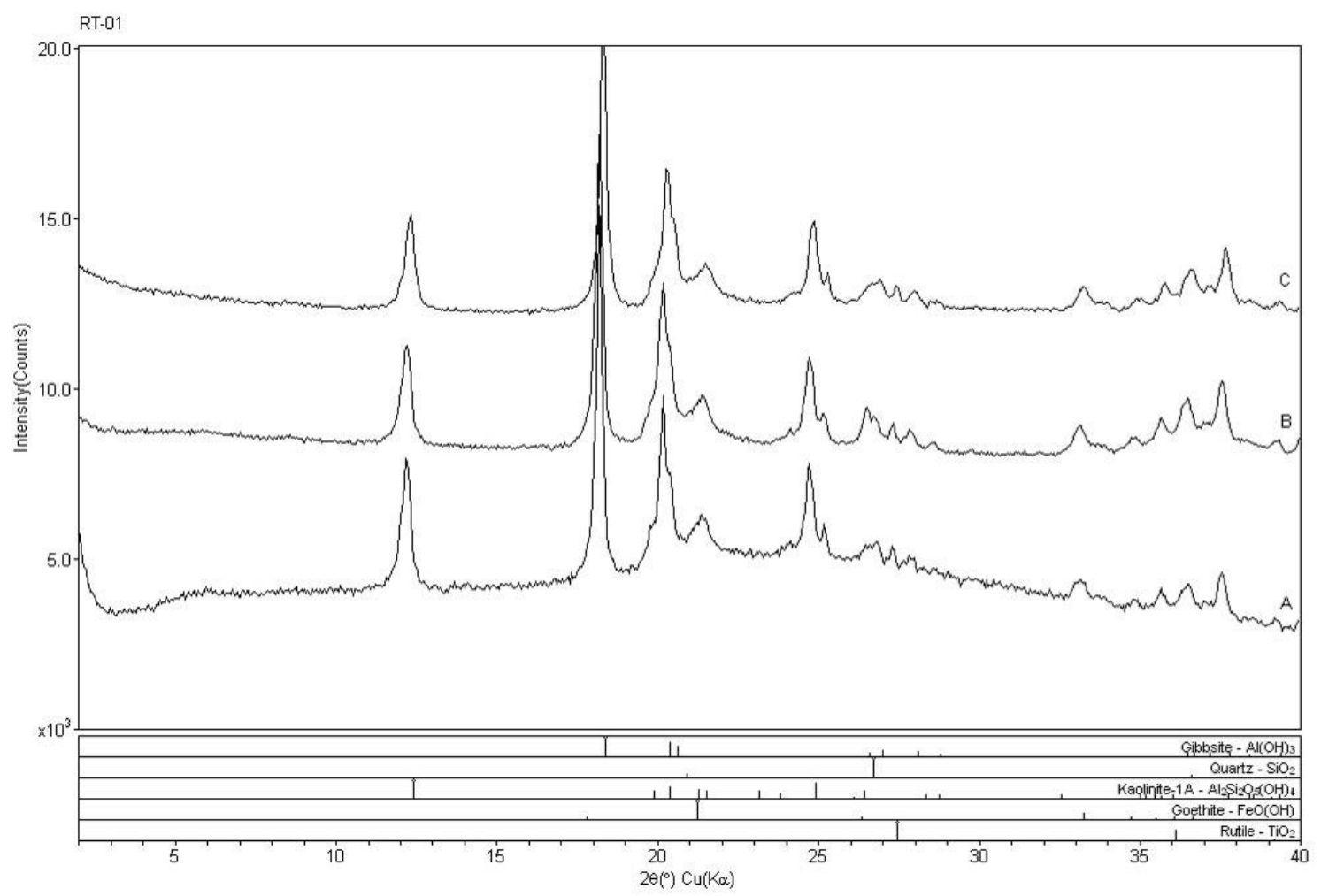

Campus Univ Darby Ribeiro

[RADOXIIG] Wednesday, December 23, 2015 09:32a MDIIJADE:

Figura 3.26 - Difratometria de raios-X do canteiro 1 (NPK sem calagem). Notar que a mineralogia é típica de Latossolo com gibbsita, quartzo, caulinita, goethita e rutilo. Não há variação significativa ao longo do ano. A) Primeiro estágio (após 4 meses); B) Segundo estágio (após 8 meses); C) Terceiro estágio (após 12 meses).

Canteiro $2(\mathbf{N P K}+\mathbf{C})$ : Nesta porção, ainda que tenha sido feito calagem, não foram encontrados na difratometria minerais carbonáticos, somente a mineralogia de quartzo, caulinita, gibbsita, goethita, ilita e rutilo (Figura 3.27). A ausência de carbonatos provavelmente é devido ao relativo alto limite de detecção do aparelho ou a rápida dissolução do material.

Canteiro 3 (F(120 kg)): A aplicação em grande quantidade de pó de fosforito brechado por si só, não indicaria uma evolução mineralógica importante com a formação de minerais do tipo 2:1. Esta aplicação somente adicionaria ao solo, minerais fosfáticos. Nos resultados apresentados na Figura 3.28 nota-se que além dos minerais encontrados nas amostras anteriores como caulinita, gibbsita, goethita, quartzo e rutilo são também encontrados minerais como ilita e fluorapatita. Observar que a ilita provavelmente é oriunda do próprio Latossolo, já a fluorapatita é proveniente do processo de rochagem. 


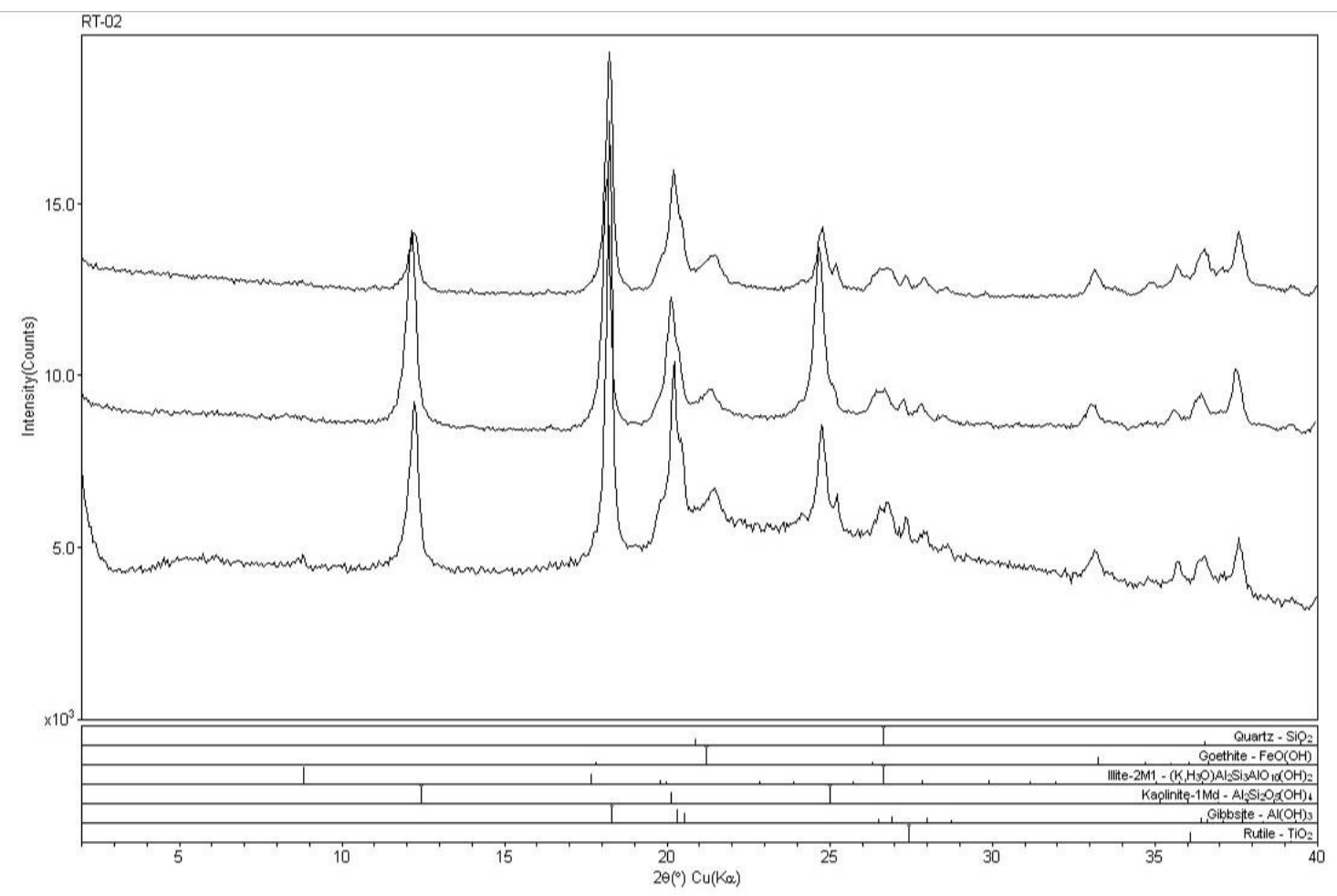

Figura 3.27 - Difratometria de raios-X do canteiro 2 (NPK com calagem). Notar mineralogia típica de Latossolo com presença de caulinita, quartzo, gibbsita, goethita, ilita e rutilo. A) Primeiro estágio (após 4 meses); B) Segundo estágio (após 8 meses); C) Terceiro estágio (após 12 meses).

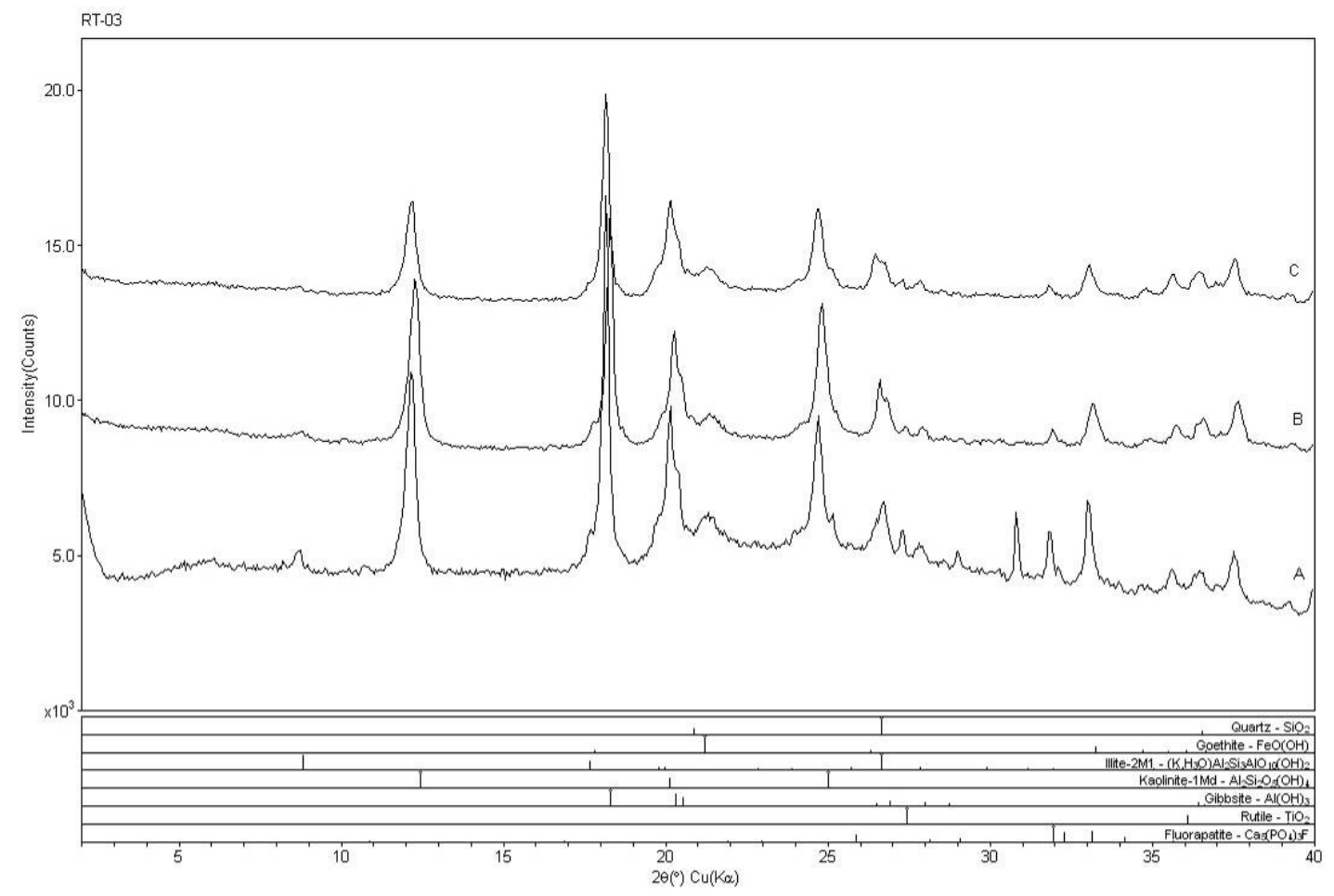

Figura 3.28 - Difratometria de raios-X do canteiro 3 (fosforito $(120 \mathrm{~kg}$ ) sem calagem). Notar a presença do mineral de fluorapatita além dos minerais comuns em Latossolo como quartzo, goethita, ilita, caulinita, gibbsita e rutilo. A) Primeiro estágio (após 4 meses); B) Segundo estágio (após 8 meses); C) Terceiro estágio (após 12 meses). 
Canteiro 4 (F (120 kg) + C): Nesta área, onde se utilizou fosforito e calagem não é esperado a presença de minerais neoformados. Entretanto, no estudo mineralógico notou-se a ocorrência de uma assembleia mineral mais complexa onde além da ocorrência de minerais comuns em Latossolos (quartzo, caulinita, gibbsita, goethita, rutilo, anatásio e ilita), foram encontrados montmorilonita e fluorapatita oriundos da rochagem (Figura 3.29). Ainda que a montmorilonita tenha sido encontrado com picos mais intensos nas etapas A e B, verifica-se a presença deste mineral quando analisamos exclusivamente o difratograma da etapa $\mathrm{C}$ (Figura 3.30).

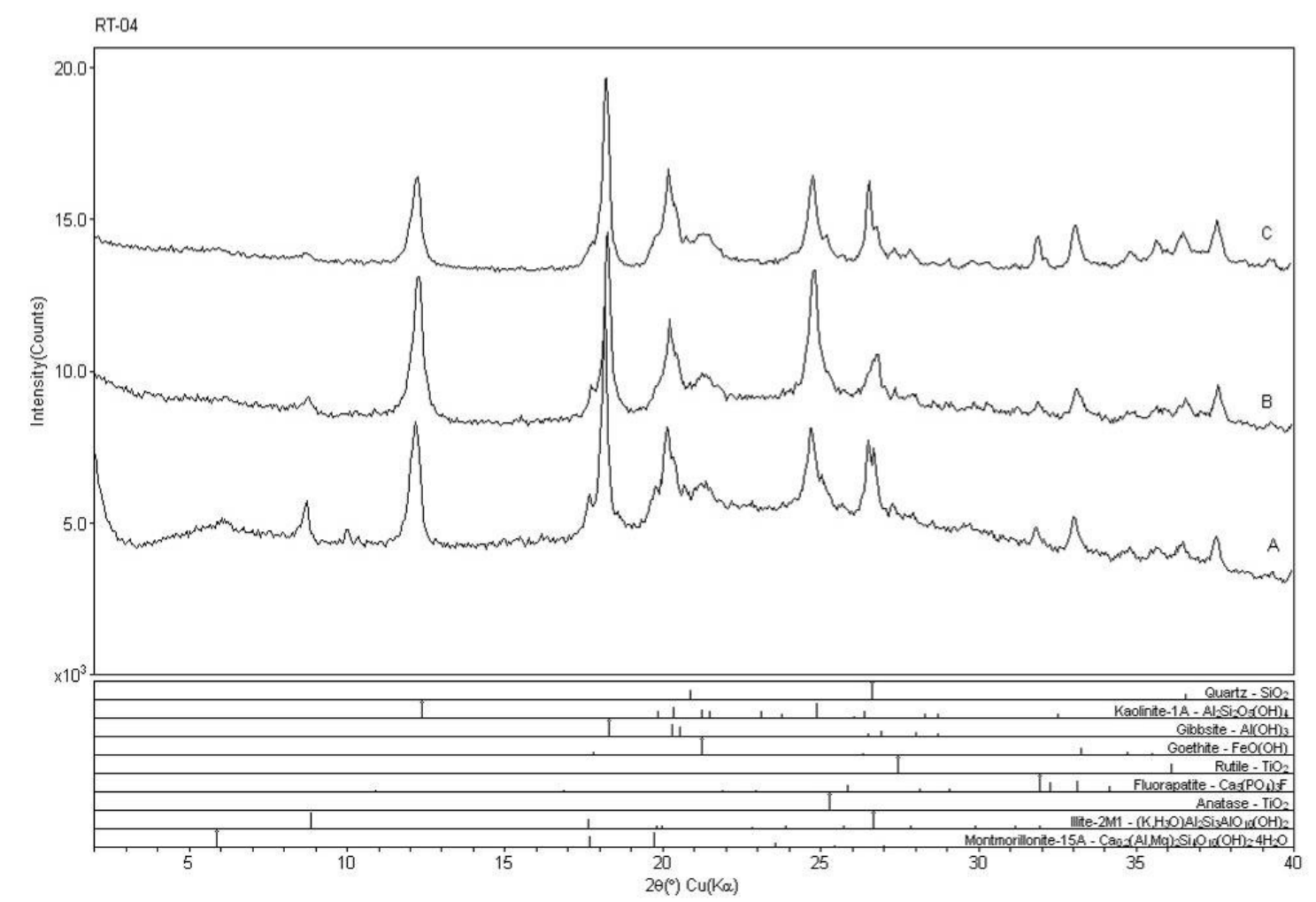

Campus Univ Darby Ribeiro

[RAO-XIG] Wednesday, December 23, 2015 09:50a MMOIJADE:

Figura 3.29 - Difratometria de raios-X do canteiro 4 (fosforito $(120 \mathrm{~kg}$ ) com calagem). Assembleia mineralógica mais complexa, com a ocorrência de quartzo, caulinita, gibbsita, goethita, rutilo, anatásio, ilita, fluorapatita e montmorilonita. A ocorrência destes últimos dois minerais é devido a aplicação de pó de rocha. A) Primeiro estágio (após 4 meses); B) Segundo estágio (após 8 meses); C) Terceiro estágio (após 12 meses). 


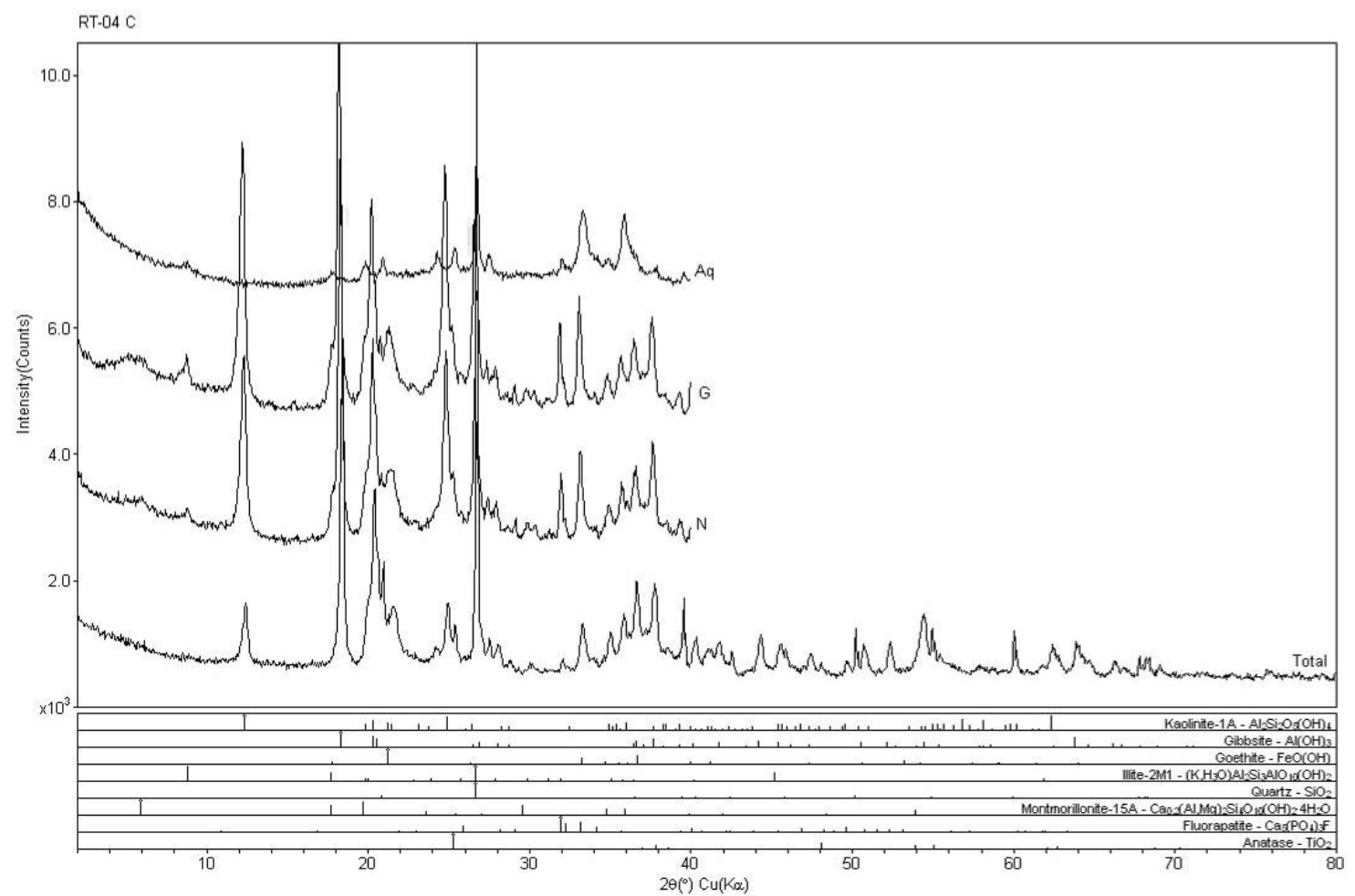

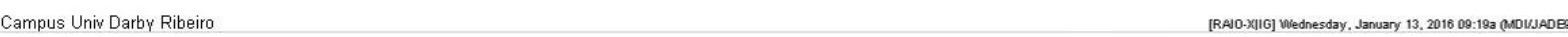

Figura 3. 30 - Difratometria de raios-X para a amostra do canteiro 4 no terceiro estágio (C). Ainda que o pico não esteja muito intenso é possível verificar a presença da montmorilonita. Aq) Aquecida; G) Glicolada; N) Fração argila (normal).

Canteiro $5(\mathbf{F}(60 \mathrm{~kg})+\mathbf{B}(80 \mathrm{~kg}))$ : O uso do pó de basalto aumenta a probabilidade da neoformação mineral, visto que as rochas ígneas possuem estados de equilíbrios originais de alta pressão e temperatura, consequentemente, são muito mais instáveis na superfície (Pomerol et al. 2013). No experimento analisado foram encontrados além dos minerais típicos de Latossolos (quartzo, caulinita, gibbsita, goethita e ilita) minerais do grupo dos fosfatos (fluorapatita) e minerais do tipo 2:1 como a vermiculita (Figura 3.31). Notar que assim como no canteiro 4 a vermiculita é encontrada de forma mais relevante na primeira e segunda etapas (A e B), indicando que na etapa seguinte $(\mathrm{C})$ provavelmente ocorreu diminuição na concentração deste mineral no solo (Figura 3.32). 


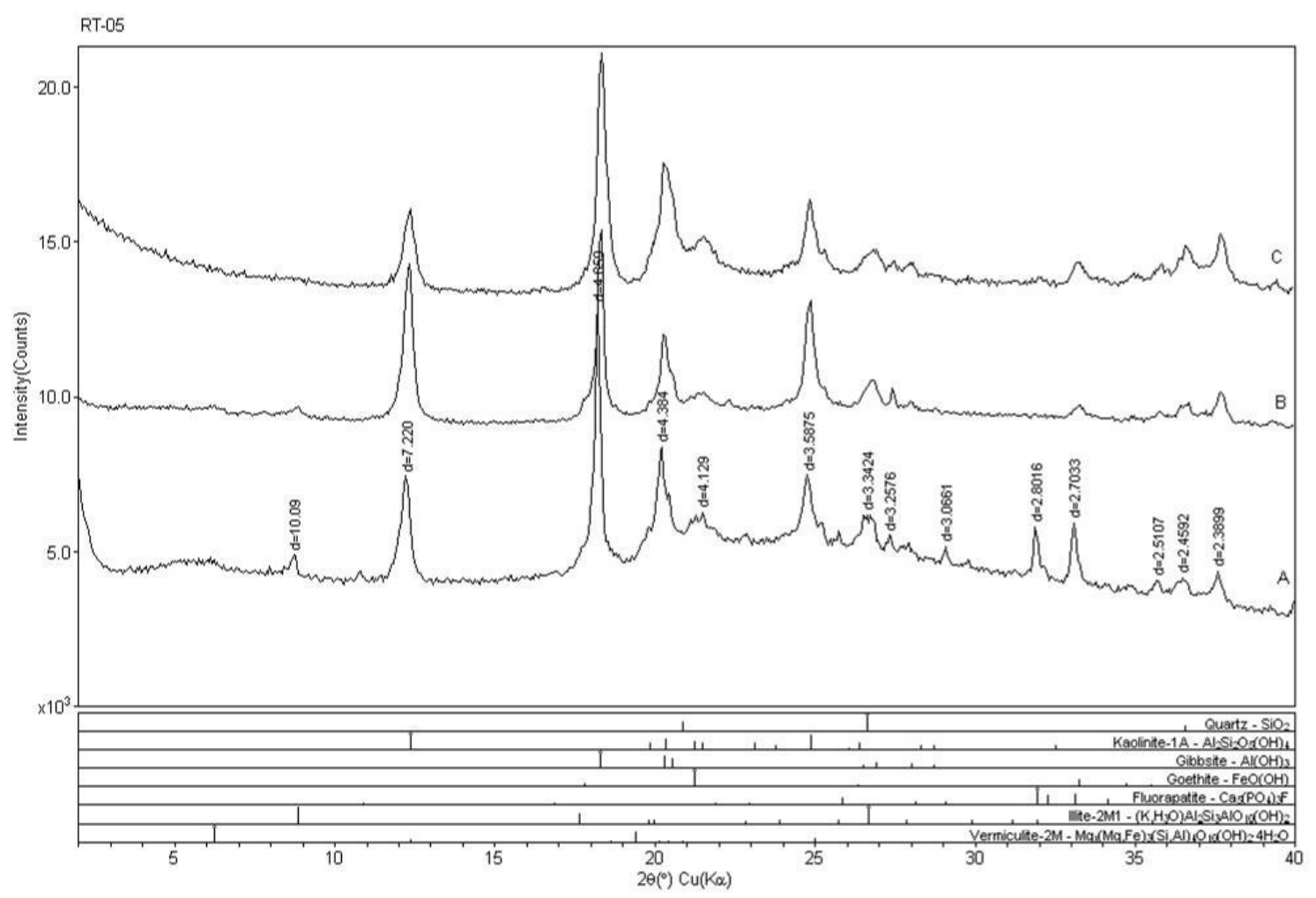

Figura 3.31 - Difratometria de raios-X do canteiro 5 (fosforito $(60 \mathrm{~kg}$ ) e basalto $(80 \mathrm{~kg})$ ). Ocorrem minerais típicos de Latossolos (quartzo, caulinita, gibbsita, goethita e ilita) bem como minerais oriundos do procedimento de rochagem pertencente ao grupo dos fosfatos (fluorapatita) e do grupo das argilas do tipo 2:1 como a vermiculita. A) Primeiro estágio (após 4 meses); B) Segundo estágio (após 8 meses); C) Terceiro estágio (após 12 meses).

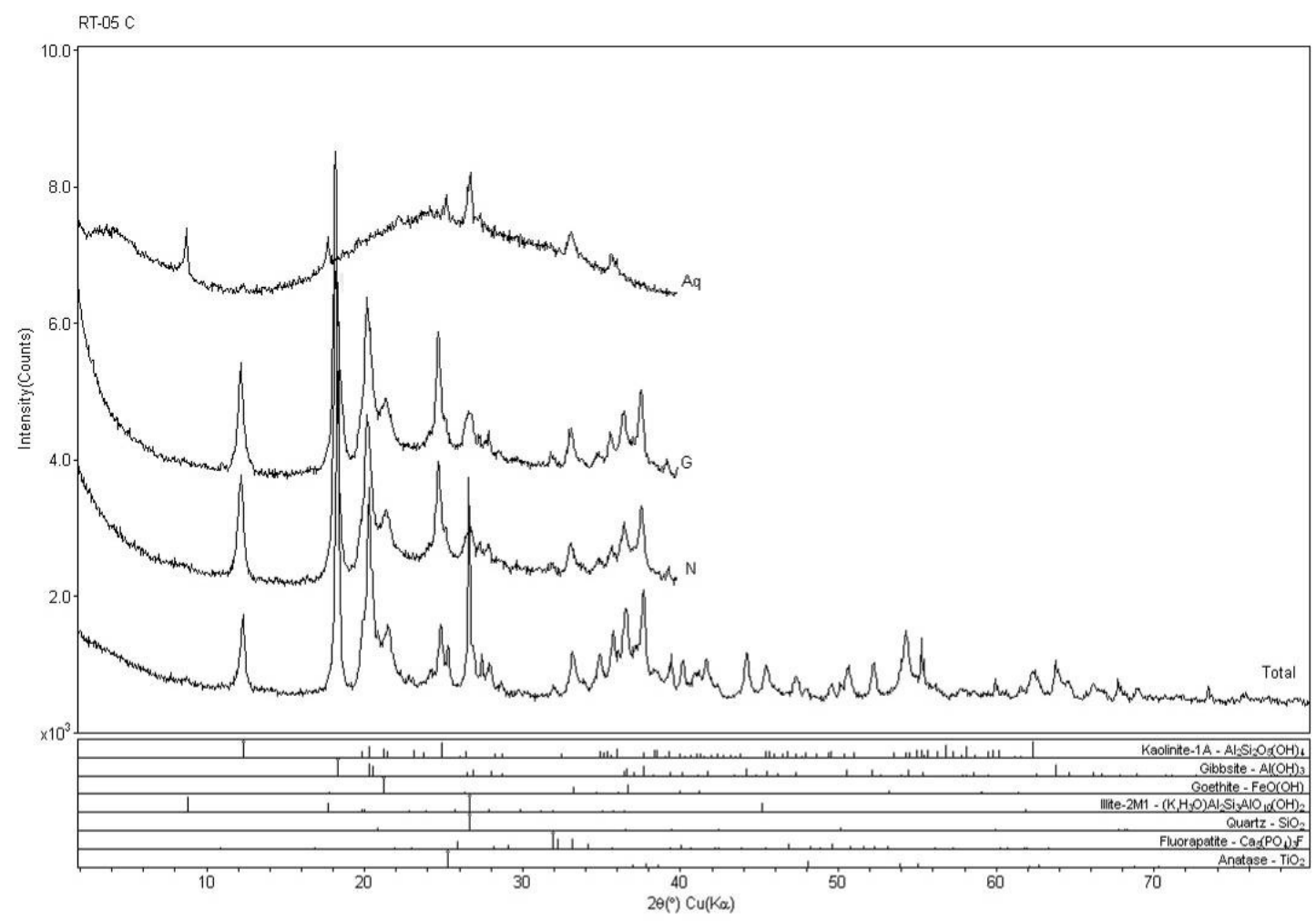

Figura 3. 32 - Difratograma do canteiro 5 no terceiro estágio (C). Nesta figura não é verificado de forma clara algum pico representativo de minerais 2:1 com exceção da ilita. Aq) Aquecida; G) Glicolada; N) Fração argila (normal). 
Canteiro $6(\mathbf{F}(60 \mathrm{~kg})+\mathrm{B}(80 \mathrm{~kg})+\mathrm{C})$ : Área com complexidade mineralógica interessante (Figura 3.33) onde além de minerais típicos do Latossolo são encontrados fluorapatita e anortita nos três estágios (A, B e C). Já a augita e vermiculita apresentam picos mais acentuados no estágio A e posteriormente no B. Vale lembrar que ainda que o pico da vermiculita seja menos intenso na etapa C é possível observa-lo na Figura 3.34.

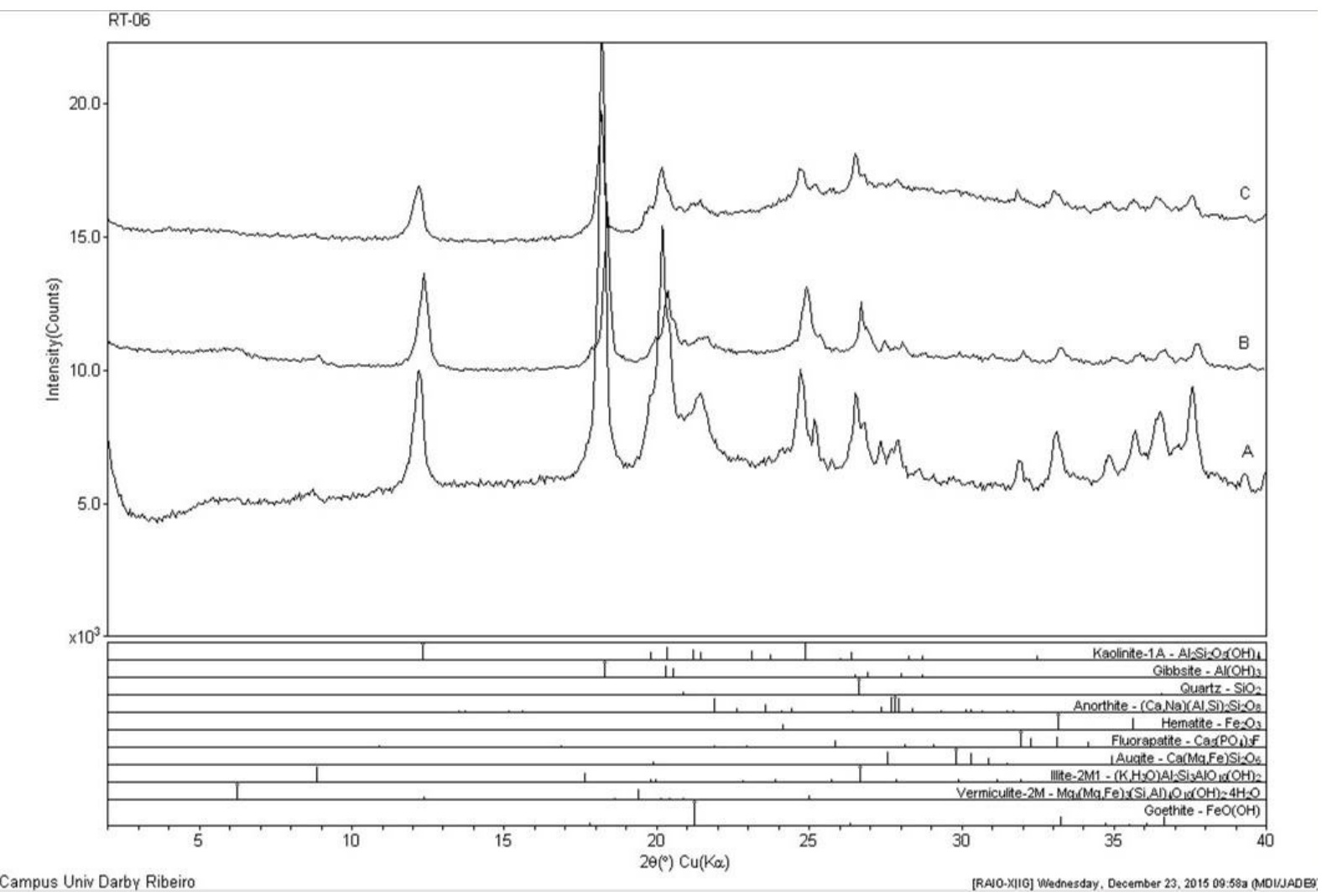

Figura 3.33 - Difratometria de raios-X do canteiro 6 (fosforito $(60 \mathrm{~kg})$ e basalto $(80 \mathrm{~kg})$ com calagem). Notar uma mineralogia mais complexa relacionada ao uso de pós de rocha com a presença de anortita, fluorapatita, augita e vermiculita. Além disso, verifica-se a presença de minerais típicos de Latossolo como a caulinita, hematita, gibbsita, goethita, quartzo e ilita. A) Primeiro estágio (após 4 meses); B) Segundo estágio (após 8 meses); C) Terceiro estágio (após 12 meses). 


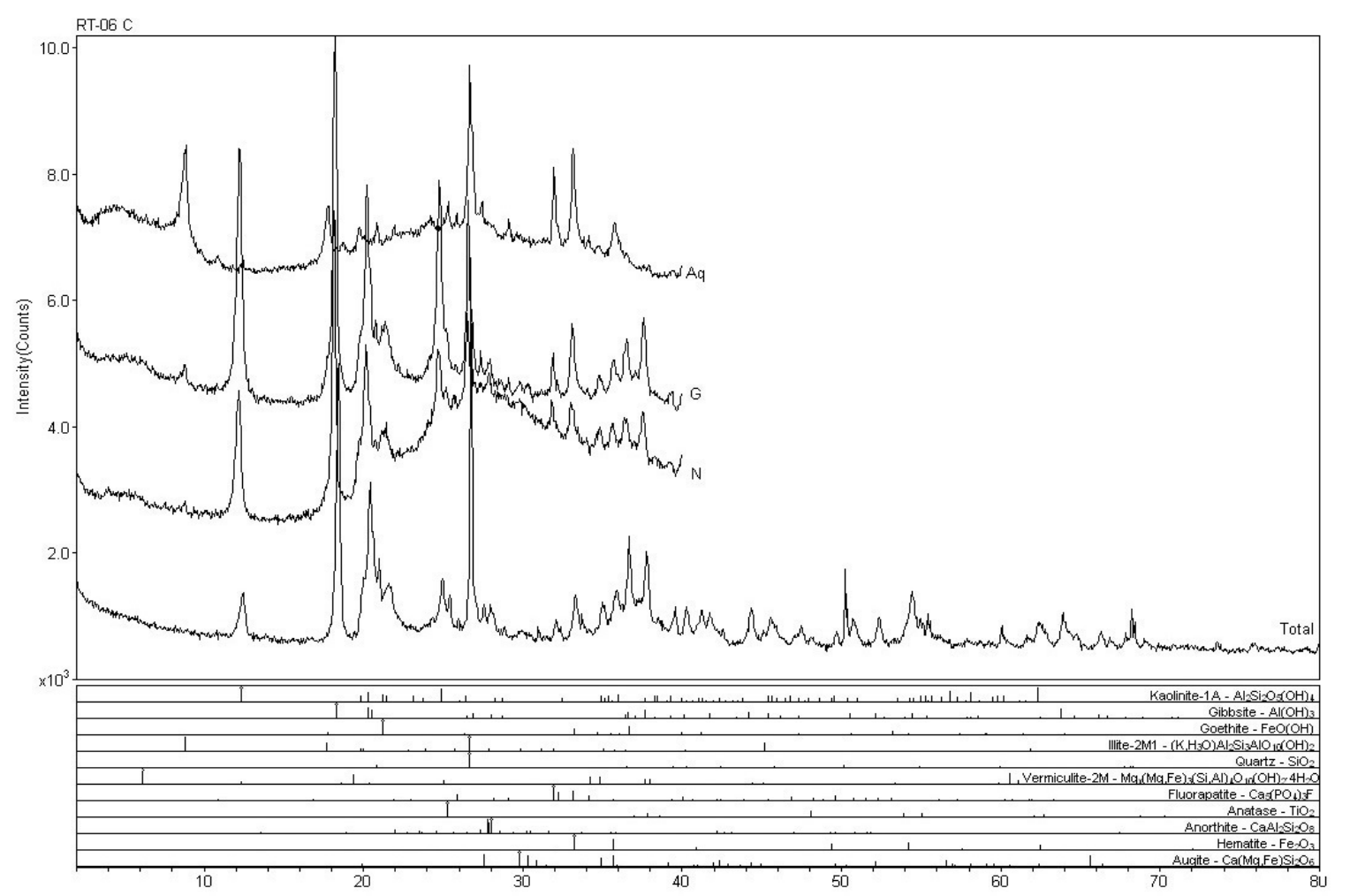

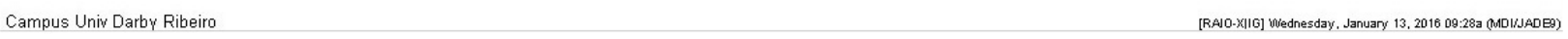

Figura 3.34 - Difratograma do canteiro 6 na terceira etapa (C). Onde se verifica a presença do argilomineral vermiculita. Este mineral é representado por um pico de baixa intensidade e de difícil distinção. Pode ocorrer a presença de montmorilonita mascarado pelo pico de vermiculita. Aq) Aquecida; G) Glicolada; N) Fração argila (normal).

Canteiro 7 (F $(20 \mathrm{~kg})$ + B (80 kg)): Apresenta importante quantidade de minerais provenientes dos pós de rocha como anortita, albita e fluorapatita verificados em todas as etapas (A, B e C). Além disso, minerais como montmorilonita e augita tiveram picos mais significativos somente nas amostras A e B (Figura 3.35 e 3.36). Uma importante observação é a possível existência de vermiculita a qual apresenta seu pico mascarado pela presença da montmorilonita. 

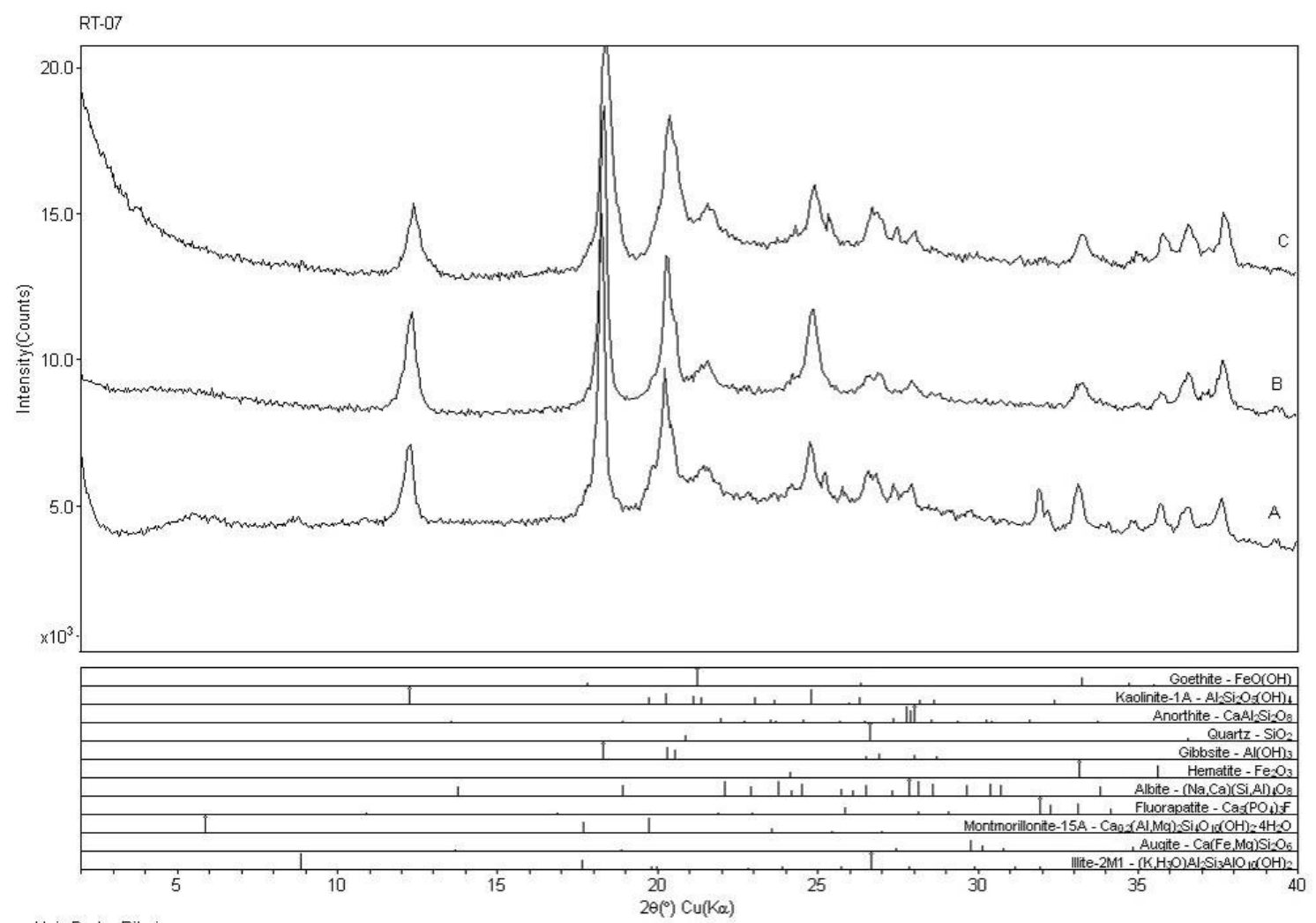

Campus Univ Darby Ribeiro

[RAI0-XIG] Wednesday. December 23, 2015 10:04a MMIIJADES

Figura 3.35 - Difratometria de raios-X do canteiro 7 (fosforito $(20 \mathrm{~kg})$ e basalto $(80 \mathrm{~kg})$ ). Notar a ocorrência de montmorilonita e augita somente nos períodos A e B. Já a fluorapatita anortita, albita, hematita, caulinita, quartzo, gibbsita, goethita e ilita estão presentes em todos os estágios. A) Primeiro estágio (após 4 meses); B) Segundo estágio (após 8 meses); C) Terceiro estágio (após 12 meses).
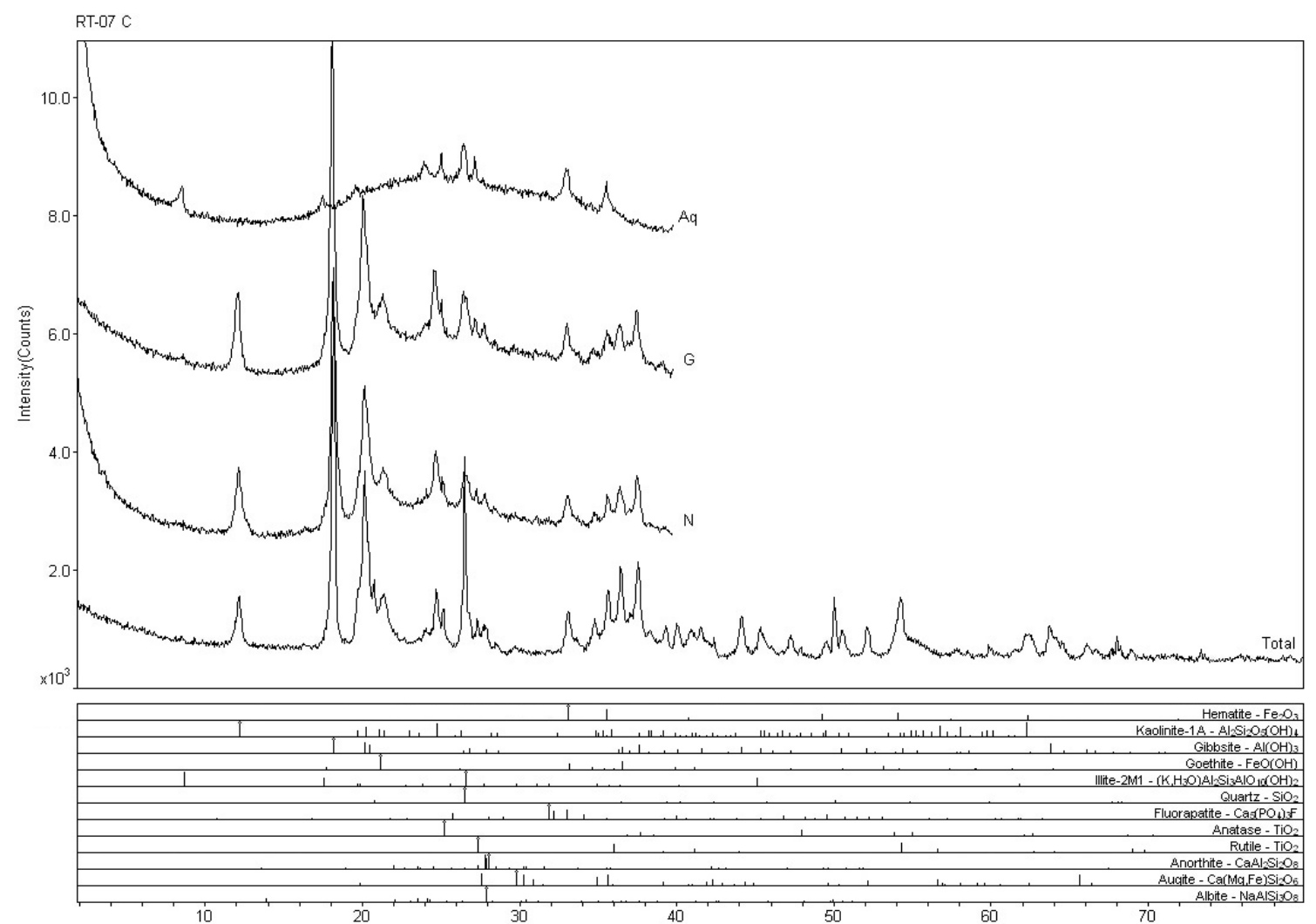

Campus Univ Darby Ribeiro

RAO0-X||G] Wednesday. January 13, 2016 09:37a MOIJJADE

Figura 3.36 - Difratograma da amostra 7 no terceiro estágio (C). Nele não são encontrados minerais 2:1 com exceção da ilita. Aq) Aquecida; G) Glicolada; N) Fração argila (normal). 
Canteiro 8 (F (20kg) + B (80kg) + C)): A mineralogia adicional em decorrência do uso de rochagem mostra a presença de anortita, fluorapatita, augita e vermiculita (Figura 3.37). Os picos de augita e vermiculita são mais evidentes somente nos estágios A e B ainda que apareçam no estágio C. Os outros minerais aparecem com variação menor de intensidade em todos os estágios (A, B, C). Na Figura 3.38 além de observar o pico pouco intenso da vermiculita, nota-se a presença de dolomita oriunda do processo de calagem.

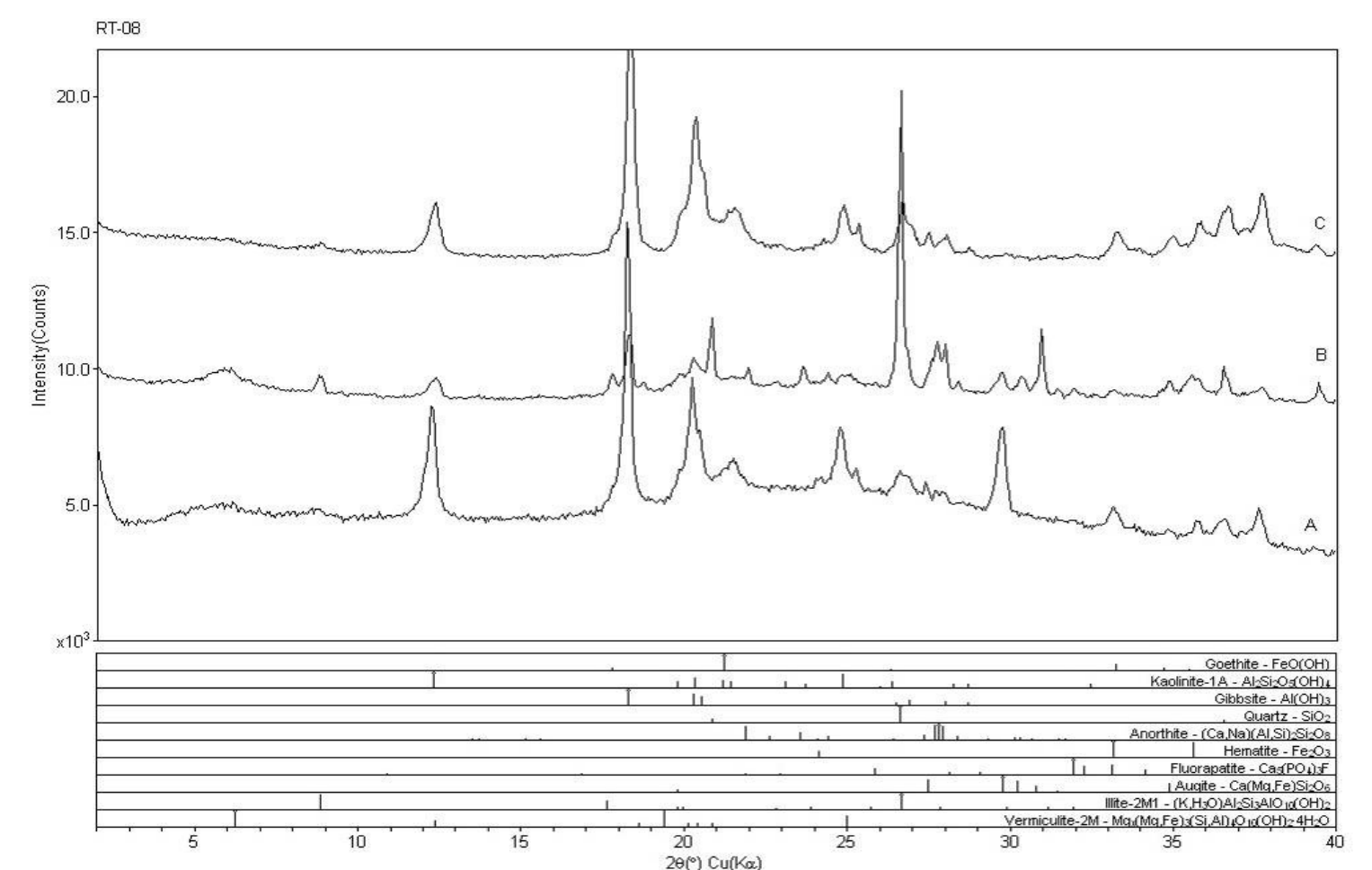

Campus Univ Darby Ribeiro

Figura 3. 37 - Difratometria de raios-X do canteiro 8 (fosforito (20kg) e basalto ( $80 \mathrm{~kg}$ ) com calagem). A mineralogia adicionada pelo uso da rochagem corresponde aos minerais de anortita, fluorapatita, augita, e vermiculita. Os picos de augita e vermiculita são evidentes somente nos estágios A e B. Já os outros minerais são típicos do Latossolo e não apresentam variação significativa entre os estágios $\mathrm{A}, \mathrm{B}, \mathrm{C}$ (hematita, caulinita, goethita gibbsita, quartzo e ilita). A) Primeiro estágio (após 4 meses); B) Segundo estágio (após 8 meses); C) Terceiro estágio (após 12 meses). 


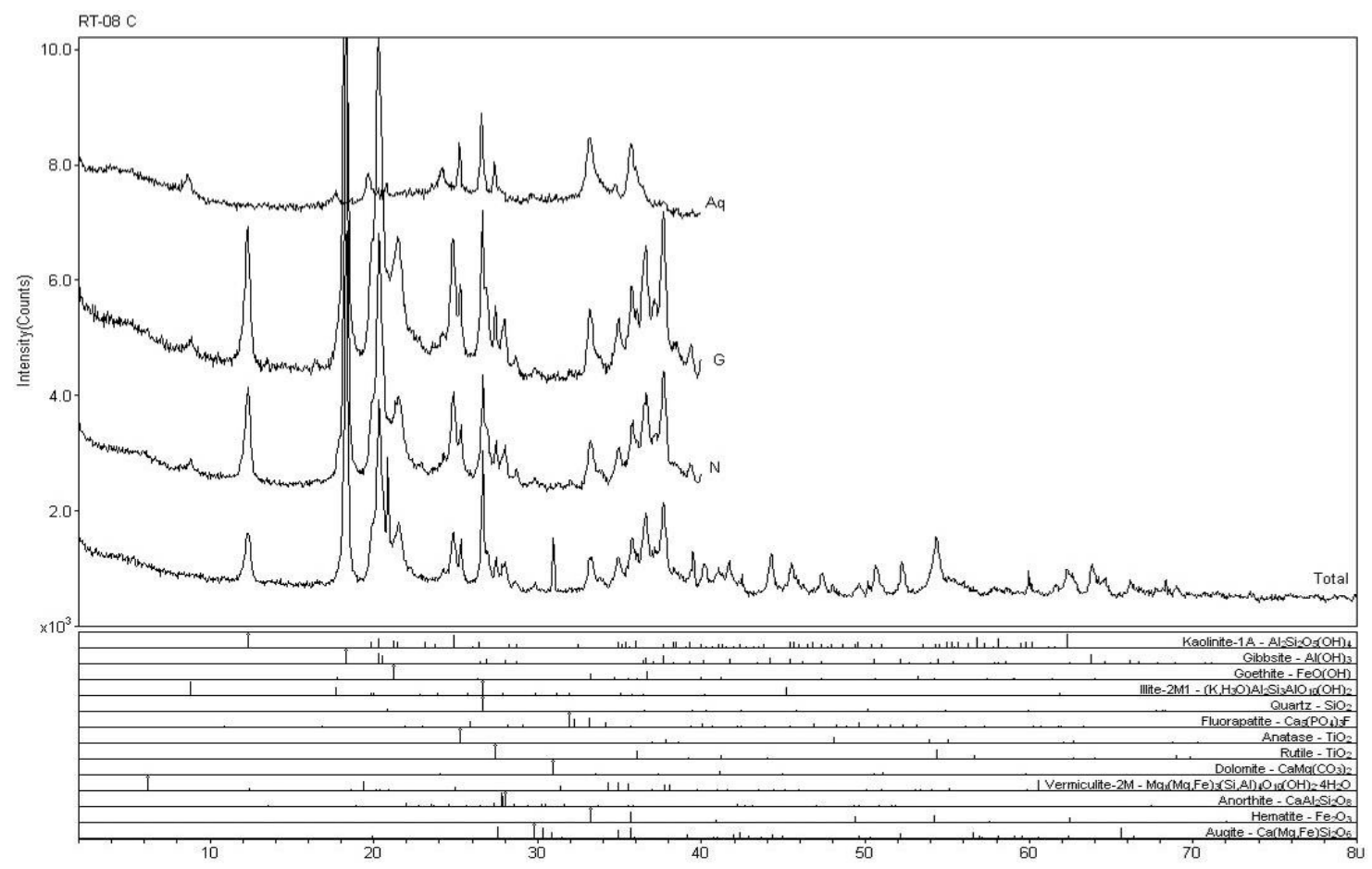

Figura 3. 38 - Difratograma da amostra 8 no terceiro estágio (C). Notar que o pico da vermiculita está muito pouco intenso especialmente se comparado com os picos do mesmo mineral nos estágios anteriores (A e B). Aq) Aquecida; G) Glicolada; N) Fração argila (normal).

Canteiro 9 (B (120kg)): A mineralogia relacionado ao pó de basalto revela a presença de anortita, albita e augita os quais aparecem com intensidade semelhante nas três etapas (Figura 3.39). Já a vermiculita também oriunda do pó de basalto aparece com intensidade significativa somente nos estágios A e B (Figura 3.40). Os minerais comuns presentes no Latossolo são a caulinita, quartzo, gibbsita, goethita, hematita e ilita. 


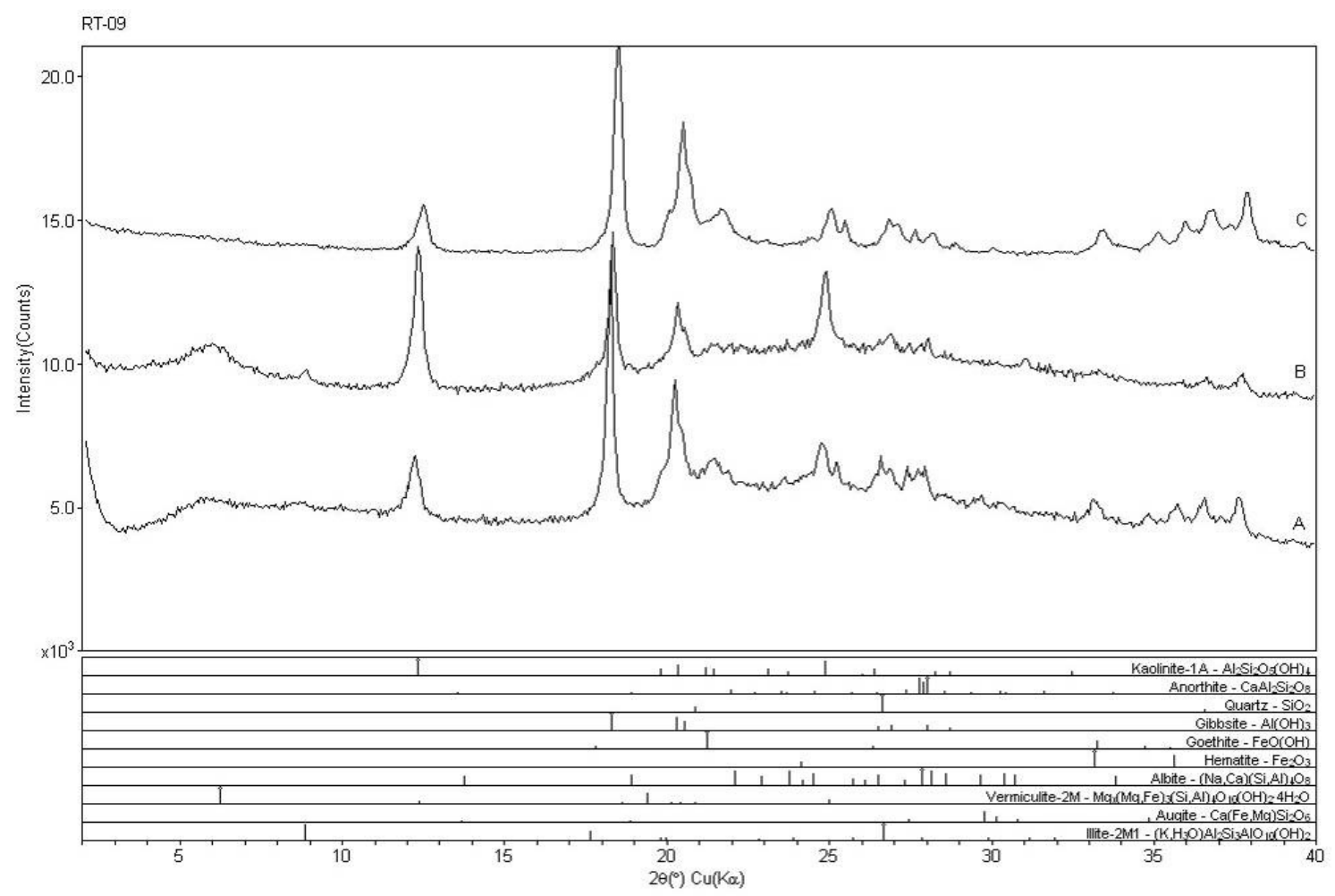

Campus Univ Darby Ribeiro

[RANO-XIG] Wednesday, December 23, 2015 10:14a MMOIJADE:

Figura 3.39. Difratometria de raios-X do canteiro 9 (Basalto $(120 \mathrm{~kg})$ ). $\mathrm{O}$ uso do pó de basalto adiciona ao solo minerais como anortita, albita e augita os quais aparecem com intensidade semelhante nas três etapas. Já a vermiculita aparece com intensidade significativa somente nos estágios A e B. Por fim existem os minerais típicos do Latossolo como a caulinita, quarzo, gibbsita, hematita, goethita e ilita.
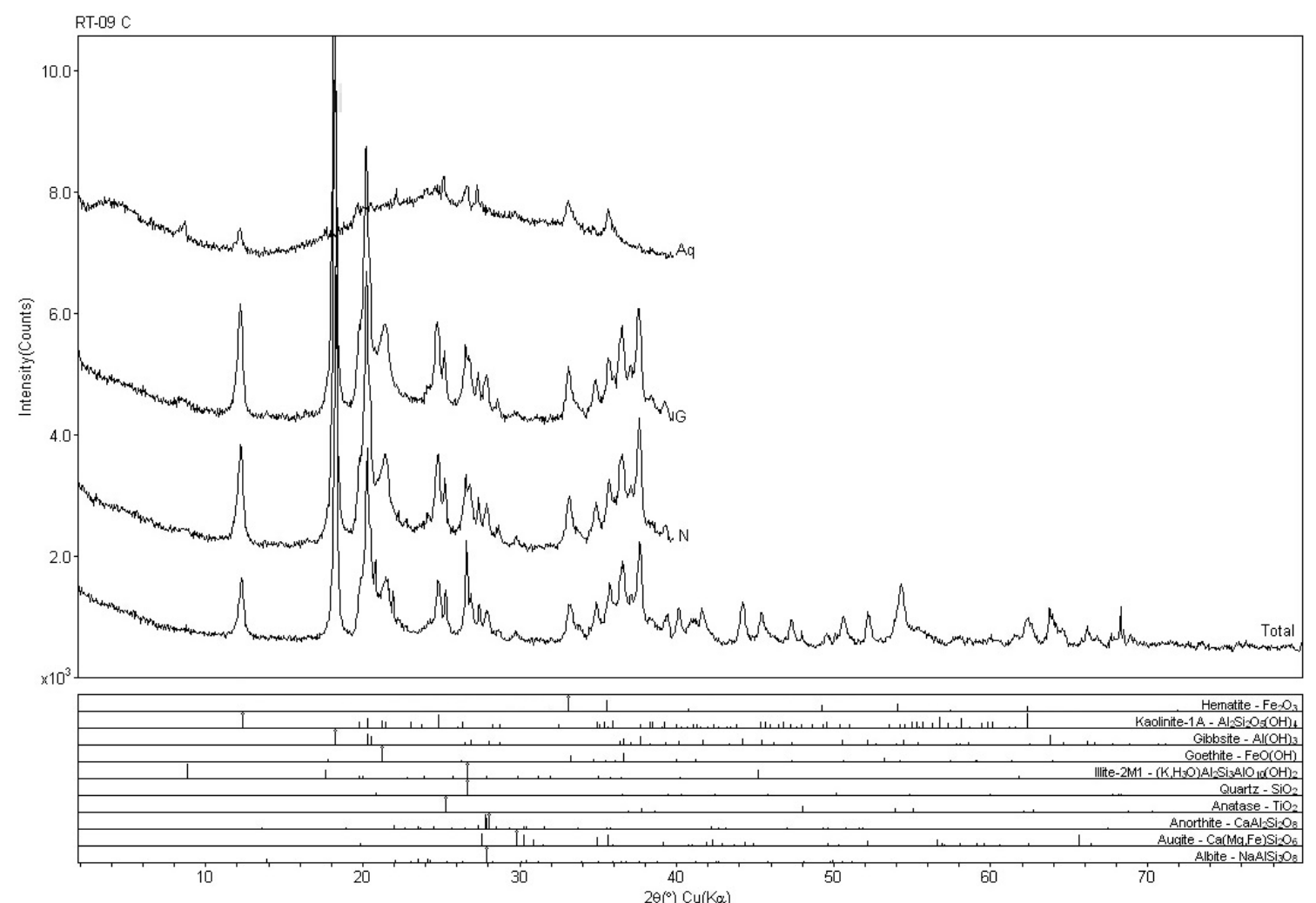

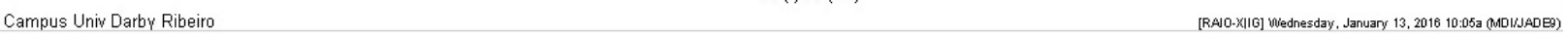
Figura 3.40 - Difratograma do canteiro 9 no terceiro estágio (C). Notar a ausência do mineral vermiculita. Aq) Aquecida; G) Glicolada; N) Fração argila (normal).

Canteiro $10($ B $(120 \mathrm{~kg})+$ C): Minerais adicionados devido ao método da rochagem são a anortita, albita, augita e montmorilonita (Figura 3.41). Sendo que o último mineral citado 
apresenta picos mais significativos nas duas primeiras etapas (A e B) (Figura 3.41 e 3.42). Ainda ocorrem minerais comuns nos Latossolos como caulinita, quartzo, gibbsita, hematita, goethita e ilita.

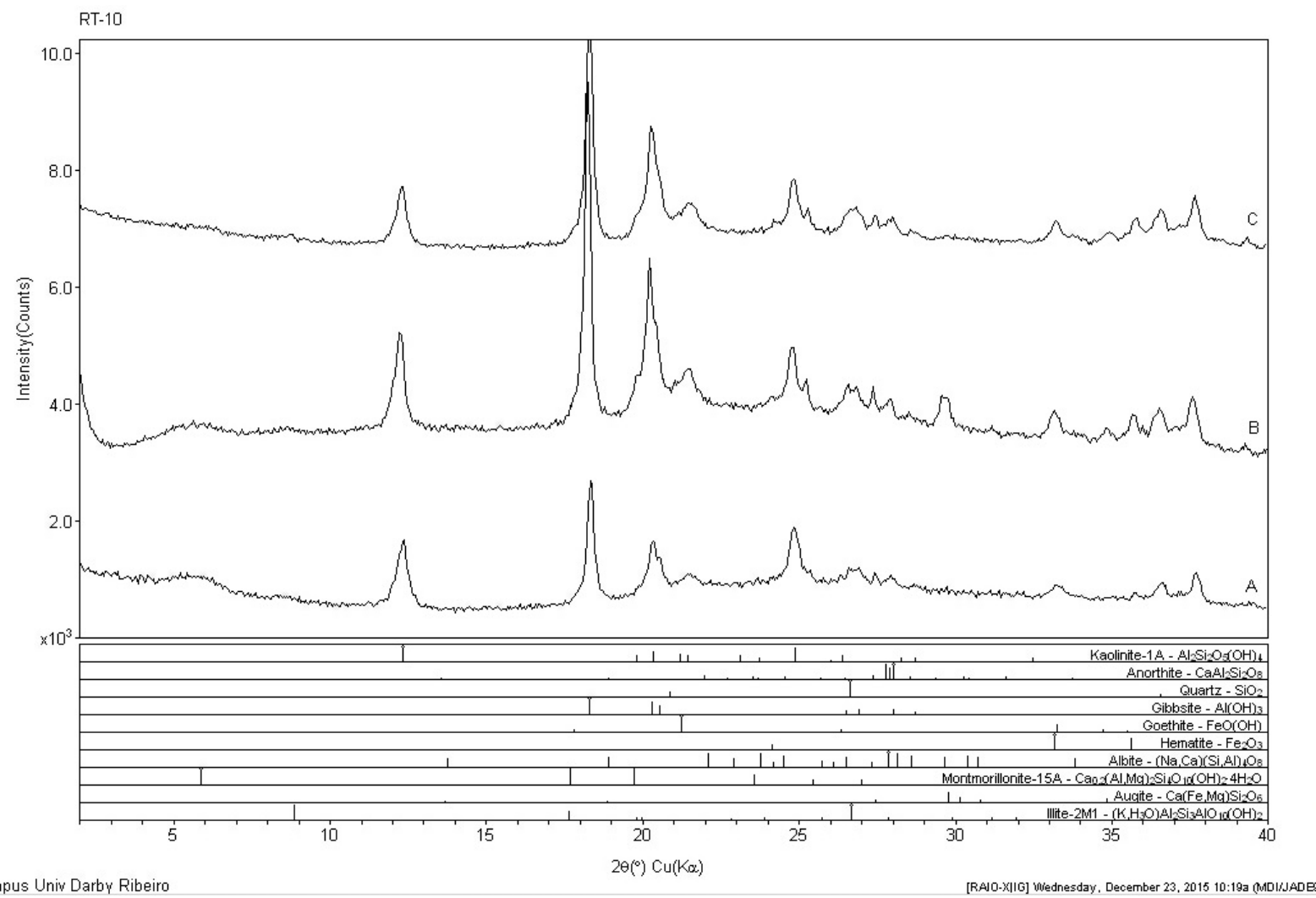

Figura 3.41 - Difratometria de raios-X do Canteiro 10 (basalto $(120 \mathrm{~kg})$ com calagem). A mineralogia decorrente da rochagem é constituida por anortita, albita, augita e montmorilonita. O último mineral citado apresenta picos significativos somente nas duas primeiras etapas (A e B). Ainda ocorrem minerais típicos dos Latossolos como caulinita, quartzo, gibbsita, ilita, hematita e goethita. A) Primeiro estágio (após 4 meses); B) Segundo estágio (após 8 meses); C) Terceiro estágio (após 12 meses). 


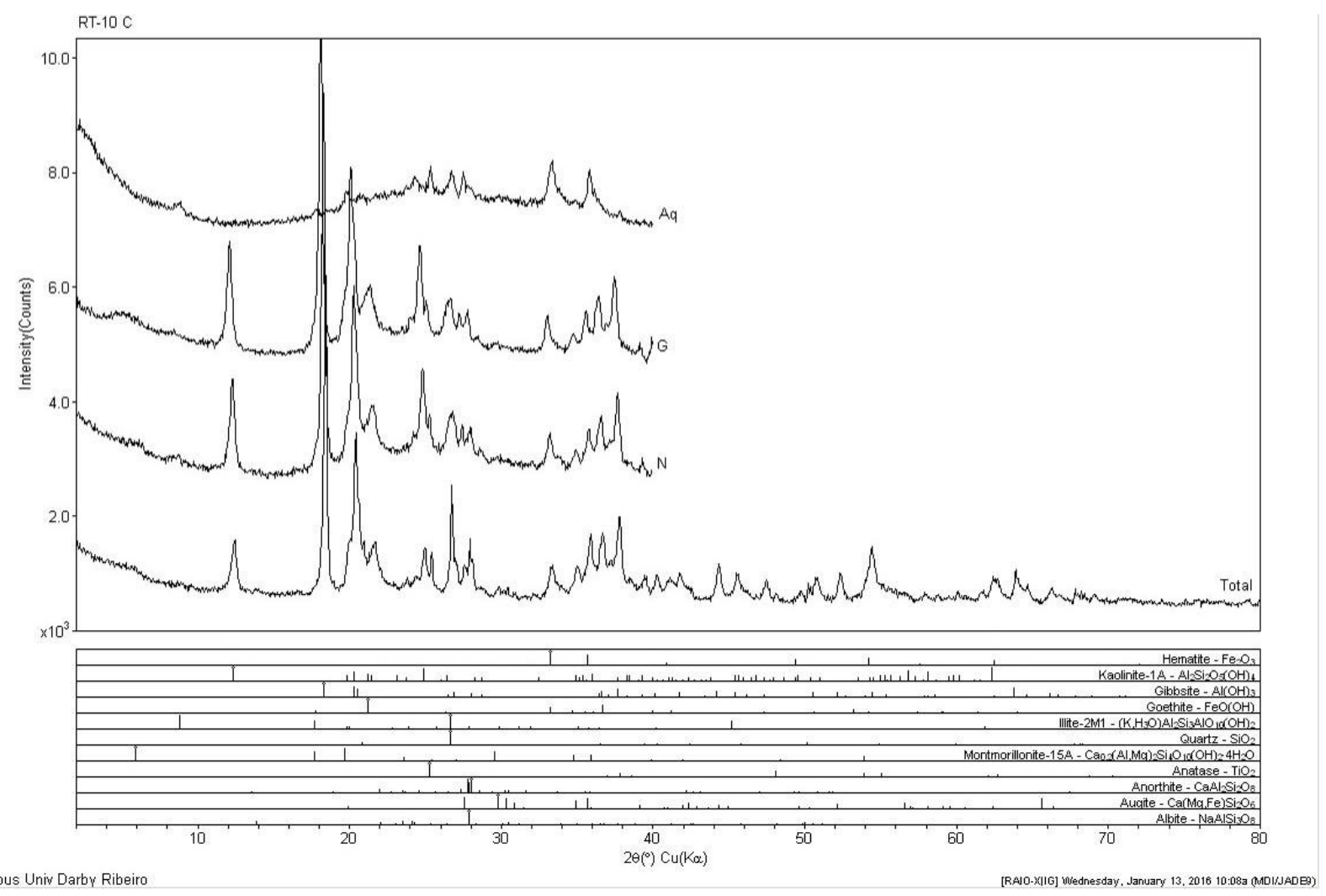

Figura 3. 42. Difratograma da amostra do canteiro 10 no terceiro estágio (C). Notar o leve pico de montmorilonita. Aq) Aquecida; G) Glicolada; N) Fração argila (normal).

Canteiro 11 (DF (120 kg)): O uso de dolomito fosfatado não fornece uma grande variedade mineralógica ao solo sendo encontrados, de forma geral, minerais típicos do Latossolo como caulinita, quartzo, gibbsita, goethita, hematita e ilita (Figura 3.43). O único mineral adicionado pelo experimento foi a dolomita, a qual ainda que tenha grande importância na correção do pH apresenta pouca importância no aspecto da neoformação mineral.

Canteiro 12 (L): Como esperado, a área controle na qual não se utilizou nenhum tipo de insumo apresentou mineralogia típica de Latossolo com a presença de caulinita, quartzo, gibbsita, goethita, hematita, rutilo, anatásio e ilita (Figura 3.44). Notar que nas três etapas analisadas não houve variação significativa da mineralogia. 


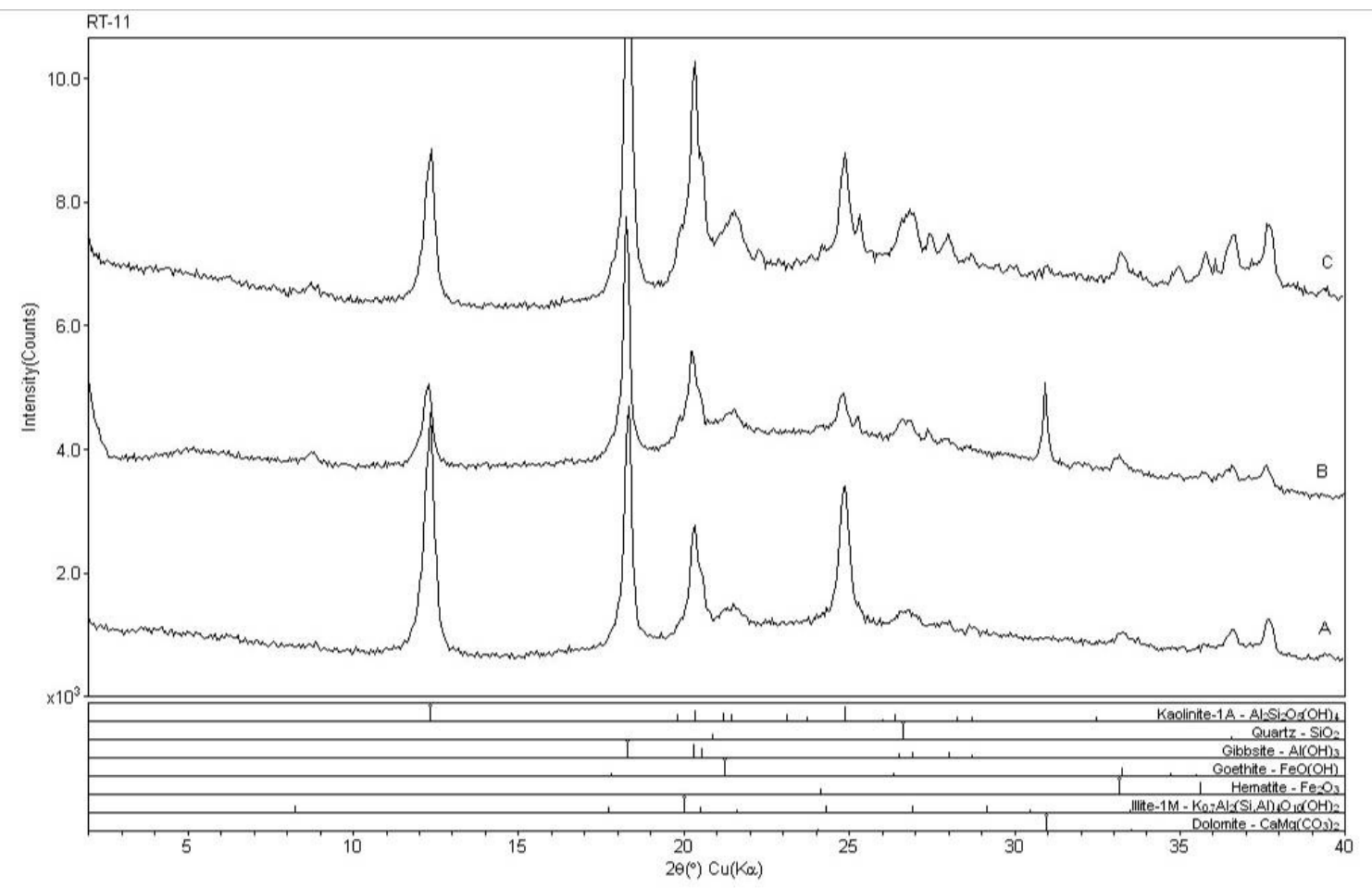

Campus Univ Darby Ribeiro

[RAO-XIIG] Wednesday, December 23, 2015 10:21a MOIJJADES

Figura 3.43 - Difratometria de raios- $X$ para o canteiro 11 (dolomito fosfatado (120kg). Apresenta mineralogia mais simples constituída por minerais típicos do Latossolo como caulinita, quartzo, gibbsita, goethita, hematita, ilita. $\mathrm{O}$ único mineral adicionado pelo experimento foi a dolomita, a qual ainda que tenha grande importância na correção do $\mathrm{pH}$ apresenta pouca importância no aspecto da neoformação mineral. A) Primeiro estágio (após 4 meses); B) Segundo estágio (após 8 meses); C) Terceiro estágio (após 12 meses).

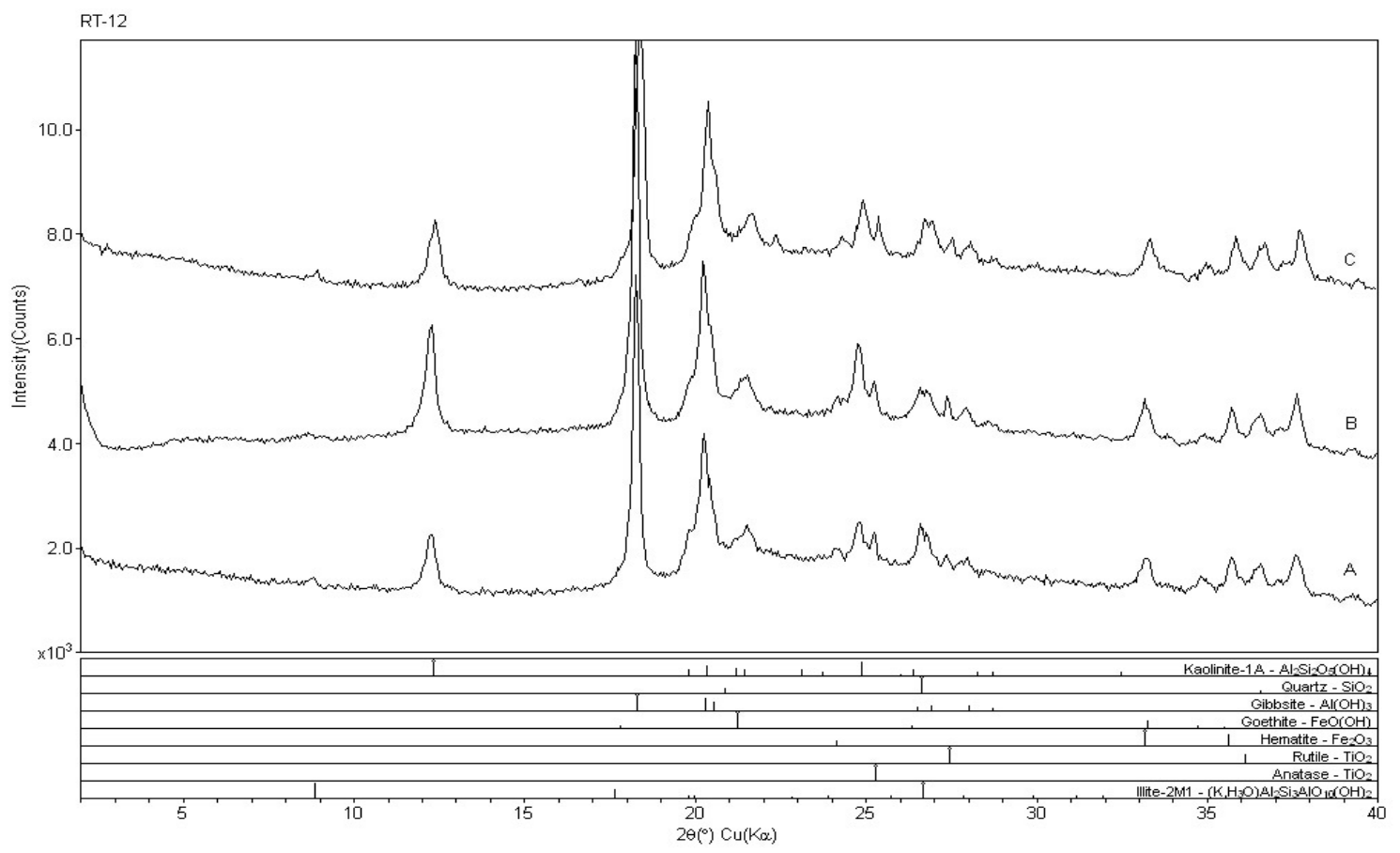

Campus Univ Darby Ribeiro

[RA0-X||16] Wednesday, December 23, 2015 10:23a (MDIJJADE9)

Figura 3.44 - Difratometria de raios-X do canteiro 12 (Latossolo controle). Notar que a mineralogia é típica de um Latossolo sem adição de insumo e não apresenta variação anual. Constitui-se por caulinita, quartzo, gibbsita, goethita, hematita, rutilo, anatásio e ilita. A) Primeiro estágio (após 4 meses); B) Segundo estágio (após 8 meses); C) Terceiro estágio (após 12 meses). 


\subsection{Resultados Agronômicos}

O resultado agronômico foi medido ao longo de três colheitas, sendo a duas primeiras realizadas de novembro a maio de 2014/15 e a terceira realizada de novembro a fevereiro de 2015/16.

Embora se tenham realizados três plantios, devido a problemas de pragas e vandalismo, somente o cálculo de área foliar teve as três repetições medidas, o peso da massa verde (MV), o peso das vagens (PV) e o peso dos grãos (PG) apresentou somente uma medida em fevereiro de 2016.

Segundo Toebe et al. (2012) para o cálculo da área foliar, é necessário medir o comprimento (C) e largura (L) da folha central. No presente estudo cada plantio teve suas medidas coletadas no primeiro e segundo mês após a semeadura. Os resultados para cada plantio estão apresentados nas tabelas 3.9, 3.10 e 3.11 .

Tabela 3.9 - Medidas de altura (H), largura (L) e comprimento (C) do primeiro plantio no decorrer de 12/11/2014 a 12/01/2015. Com os valores de L e C é possível calcular a área foliar (AF).

\begin{tabular}{|c|c|c|c|c|c|c|c|c|c|c|c|c|}
\hline \multicolumn{13}{|c|}{ Primeiro plantio $-1^{\circ}$ mês de desenvolvimento } \\
\hline \multirow[b]{2}{*}{ 臬 } & Cant.1 & Cant. 2 & Cant. 3 & Cant. 4 & Cant. 5 & Cant. 6 & Cant. 7 & Cant. 8 & Cant. 9 & Cant. 10 & Cant. 11 & Cant. 12 \\
\hline & NPK & $\mathrm{NPK}+\mathrm{C}$ & $\mathrm{F}(120 \mathrm{~kg})$ & $\begin{array}{c}F(120 \mathrm{~kg}) \\
+\mathrm{C}\end{array}$ & $\begin{array}{c}\mathrm{F}(60 \mathrm{~kg}) \\
+ \\
\mathrm{B}(80 \mathrm{~kg})\end{array}$ & $\begin{array}{c}\mathrm{F}(60 \mathrm{~kg}) \\
+ \\
\mathrm{B}(80 \mathrm{~kg}) \\
+\mathrm{C}\end{array}$ & $\begin{array}{c}\mathrm{F}(20 \mathrm{~kg}) \\
+ \\
\mathrm{B}(80 \mathrm{~kg})\end{array}$ & $\begin{array}{c}\mathrm{F}(20 \mathrm{~kg}) \\
+ \\
\mathrm{B}(80 \mathrm{~kg}) \\
+\mathrm{C}\end{array}$ & $\mathrm{B}(120 \mathrm{~kg})$ & $\begin{array}{l}\mathrm{B}(120 \mathrm{~kg}) \\
+\mathrm{C}\end{array}$ & $\begin{array}{c}\text { DF (120 } \\
\mathrm{kg})\end{array}$ & $\mathrm{L}$ \\
\hline H & 11,0 & 18,0 & 11,5 & 11,0 & 12,5 & 13,4 & 10,0 & 15,0 & 10,0 & 10,5 & 9,5 & 8,0 \\
\hline $\mathbf{L}$ & 3,2 & 6,0 & 6,2 & 5,5 & 4,5 & 5,5 & 4,0 & 5,0 & 4,5 & 4,0 & 5,5 & 3,2 \\
\hline C & 5,0 & 8,4 & 9,3 & 8,0 & 7,0 & 9,0 & 6,5 & 7,0 & 6,0 & 7,0 & 3,5 & 3,5 \\
\hline AF & 24,4 & 95,2 & 110,1 & 82,0 & 56,3 & 93,3 & 45,0 & 63,5 & 47,1 & 49,1 & 31,1 & 14,5 \\
\hline \multicolumn{13}{|c|}{ Primeiro plantio - $2^{\circ}$ mês de desenvolvimento } \\
\hline \multirow{2}{*}{ Pa } & Cant.1 & Cant. 2 & Cant. 3 & Cant. 4 & Cant. 5 & Cant. 6 & Cant. 7 & Cant. 8 & Cant. 9* & Cant. 10 & Cant. 11 & Cant. 12 \\
\hline & NPK & $\mathrm{NPK}+\mathrm{C}$ & $\mathrm{F}(120 \mathrm{~kg})$ & $\begin{array}{c}F(120 \mathrm{~kg}) \\
+C\end{array}$ & $\begin{array}{c}\mathrm{F}(60 \mathrm{~kg}) \\
+ \\
\mathrm{B}(80 \mathrm{~kg})\end{array}$ & $\begin{array}{c}\mathrm{F}(60 \mathrm{~kg}) \\
+ \\
\mathrm{B}(80 \mathrm{~kg}) \\
+\mathrm{C}\end{array}$ & $\begin{array}{c}\mathrm{F}(20 \mathrm{~kg}) \\
+ \\
\mathrm{B}(80 \mathrm{~kg})\end{array}$ & $\begin{array}{c}\mathrm{F}(20 \mathrm{~kg}) \\
+ \\
\mathrm{B}(80 \mathrm{~kg}) \\
+\mathrm{C}\end{array}$ & $\mathrm{B}(120 \mathrm{~kg})$ & $\begin{array}{l}\mathrm{B}(120 \mathrm{~kg}) \\
+\mathrm{C}\end{array}$ & $\begin{array}{c}\text { DF (120 } \\
\mathrm{kg})\end{array}$ & $L$ \\
\hline H & * & 39,4 & 30,7 & 42,6 & 33,8 & 39,0 & 30,6 & 35,2 & 10,3 & 6,3 & 22,4 & 13,5 \\
\hline L & 5,5 & 6,4 & 6,6 & 7,2 & 6,0 & 6,9 & 6,8 & 5,5 & 2,7 & 2,2 & 3,8 & 3,78 \\
\hline $\mathbf{C}$ & 5,0 & 8,2 & 8,8 & 9,5 & 8,4 & 9,0 & 9,4 & 7,0 & 4,0 & 2,6 & 4,7 & 5,52 \\
\hline AF & 48,1 & 99,5 & 112,0 & 132,2 & 95,4 & 118,0 & 123,2 & 71,1 & 13,7 & 3,3 & 28,2 & 34,4 \\
\hline \multicolumn{13}{|c|}{ Primeiro plantio - Média $1^{\circ}$ e $2^{\circ}$ mês } \\
\hline & Cant.1 & Cant. 2 & Cant. 3 & Cant. 4 & Cant. 5 & Cant. 6 & Cant. 7 & Cant. 8 & Cant. 9* & Cant. 10 & Cant. 11 & Cant. 12 \\
\hline Vo & NPK & $\mathrm{NPK}+\mathrm{C}$ & $F(120 \mathrm{~kg})$ & $\begin{array}{c}F(120 \mathrm{~kg}) \\
+C\end{array}$ & $\begin{array}{c}\mathrm{F}(60 \mathrm{~kg}) \\
+ \\
\mathrm{B}(80 \mathrm{~kg})\end{array}$ & $\begin{array}{c}\mathrm{F}(60 \mathrm{~kg}) \\
+ \\
\mathrm{B}(80 \mathrm{~kg}) \\
+\mathrm{C}\end{array}$ & $\begin{array}{c}\mathrm{F}(20 \mathrm{~kg}) \\
+ \\
\mathrm{B}(80 \mathrm{~kg})\end{array}$ & $\begin{array}{c}\mathrm{F}(20 \mathrm{~kg}) \\
+ \\
\mathrm{B}(80 \mathrm{~kg}) \\
+\mathrm{C}\end{array}$ & $\mathrm{B}(120 \mathrm{~kg})$ & $\begin{array}{l}\mathrm{B}(120 \mathrm{~kg}) \\
+\mathrm{C}\end{array}$ & $\begin{array}{c}\text { DF (120 } \\
\mathrm{kg})\end{array}$ & $\mathrm{L}$ \\
\hline $1^{\circ} \mathrm{AF}$ & 24,4 & 95,2 & 110,1 & 82,0 & 56,3 & 93,3 & 45,0 & 63,5 & 47,1 & 49,1 & 31,1 & 14,5 \\
\hline $2^{\circ} \mathrm{AF}$ & 48,1 & 99,5 & 112,0 & 132,2 & 95,4 & 118,0 & 123,2 & 71,1 & 13,7 & 3,3 & 28,2 & 34,4 \\
\hline Med. AF & 36,3 & 97,3 & 111,1 & 107,1 & 75,9 & 105,7 & 84,1 & 67,3 & 30,4 & 26,2 & 29,6 & 24,5 \\
\hline
\end{tabular}


Tabela 3. 10 - Medidas de altura $(\mathrm{H})$, largura $(\mathrm{L})$ e comprimento $(\mathrm{C})$ do segundo plantio no decorrer de 21/03/2015 a 21/05/2015. Com os valores de L e C é possível calcular a área foliar (AF).

\begin{tabular}{|c|c|c|c|c|c|c|c|c|c|c|c|c|}
\hline \multicolumn{13}{|c|}{ Segundo Plantio - $1^{\circ}$ mês de desenvolvimento } \\
\hline \multirow{2}{*}{ Po } & Cant.1 & Cant. 2 & Cant. 3 & Cant. 4 & Cant. 5 & Cant. 6 & Cant. 7 & Cant. 8 & Cant. 9 & Cant. 10 & Cant. 11 & Cant. 12 \\
\hline & NPK & $\begin{array}{c}\text { NPK + } \\
\text { C }\end{array}$ & $\mathrm{F}(120 \mathrm{~kg})$ & $\begin{array}{c}F(120 \mathrm{~kg} \\
)+C\end{array}$ & $\begin{array}{c}\mathrm{F}(60 \mathrm{~kg}) \\
+ \\
\mathrm{B}(80 \mathrm{~kg})\end{array}$ & $\begin{array}{c}\mathrm{F}(60 \mathrm{~kg}) \\
+ \\
\mathrm{B}(80 \mathrm{~kg}) \\
+\mathrm{C}\end{array}$ & $\begin{array}{c}\mathrm{F}(20 \mathrm{~kg}) \\
+ \\
\mathrm{B}(80 \mathrm{~kg})\end{array}$ & $\begin{array}{c}\mathrm{F}(20 \mathrm{~kg}) \\
+ \\
\mathrm{B}(80 \mathrm{~kg}) \\
+\mathrm{C}\end{array}$ & $\mathrm{B}(120 \mathrm{~kg})$ & $\begin{array}{l}\mathrm{B}(120 \mathrm{~kg}) \\
+\mathrm{C}\end{array}$ & $\begin{array}{c}\mathrm{DF}(120 \\
\mathrm{kg})\end{array}$ & $\mathrm{L}$ \\
\hline H & 8,9 & 13,5 & 10,6 & 23,3 & 14,6 & 19,9 & 11,6 & 12,1 & 12,9 & 11,8 & 8,3 & 8,8 \\
\hline $\mathbf{L}$ & 4,2 & 4,0 & 3,8 & 8,7 & 4,9 & 6,6 & 4,2 & 4,3 & 4,6 & 5,2 & 3,9 & 2,5 \\
\hline C & 5,0 & 7,0 & 5,6 & 12,4 & 7,5 & 10,0 & 6,1 & 6,4 & 7,3 & 7,5 & 5,4 & 3,2 \\
\hline AF & 34,9 & 49,1 & 36,1 & 213,9 & 67,4 & 126,3 & 44,4 & 47,5 & 59,6 & 72,0 & 34,8 & 8,2 \\
\hline \multicolumn{13}{|c|}{ Segundo plantio - $2^{\circ}$ mês de desenvolvimento } \\
\hline \multirow{2}{*}{ Pa } & Cant.1 & Cant.2 & Cant. 3 & Cant. 4 & Cant. 5 & Cant. 6 & Cant. 7 & Cant. 8 & Cant. 9 & Cant. 10 & Cant. 11 & Cant. 12 \\
\hline & NPK & $\begin{array}{c}\text { NPK + } \\
\text { C }\end{array}$ & $\mathrm{F}(120 \mathrm{~kg})$ & $\begin{array}{c}F(120 \mathrm{~kg}) \\
+C\end{array}$ & $\begin{array}{c}\mathrm{F}(60 \mathrm{~kg}) \\
+ \\
\mathrm{B}(80 \mathrm{~kg})\end{array}$ & $\begin{array}{c}\mathrm{F}(60 \mathrm{~kg}) \\
+ \\
\mathrm{B}(80 \mathrm{~kg}) \\
+\mathrm{C}\end{array}$ & $\begin{array}{c}\mathrm{F}(20 \mathrm{~kg}) \\
+ \\
\mathrm{B}(80 \mathrm{~kg})\end{array}$ & $\begin{array}{c}\mathrm{F}(20 \mathrm{~kg}) \\
+ \\
\mathrm{B}(80 \mathrm{~kg}) \\
+\mathrm{C}\end{array}$ & $\mathrm{B}(120 \mathrm{~kg})$ & $\begin{array}{l}\mathrm{B}(120 \mathrm{~kg}) \\
+\mathrm{C}\end{array}$ & $\begin{array}{c}\mathrm{DF}(120 \\
\mathrm{kg})\end{array}$ & $\mathrm{L}$ \\
\hline $\mathrm{H}$ & 9,9 & 25,8 & 16,4 & 51,0 & 39,8 & 33,2 & 29,0 & 23,2 & 36,6 & 26,6 & 19,8 & 8,0 \\
\hline $\mathbf{L}$ & 4,3 & 6,1 & 4,6 & 8,3 & 6,1 & 5,5 & 5,1 & 4,5 & 4,9 & 5,8 & 4,5 & 1,5 \\
\hline C & 5,7 & 8,3 & 5,9 & 11,0 & 7,0 & 7,0 & 6,6 & 5,6 & 6,3 & 7,7 & 6,0 & 2,1 \\
\hline AF & 41,9 & 95,3 & 46,9 & 178,4 & 79,1 & 70,7 & 60,2 & 43,3 & 54,6 & 82,5 & 47,5 & $-2,1$ \\
\hline \multicolumn{13}{|c|}{ Segundo plantio - Média $1^{\circ}$ e $2^{\circ}$ mês } \\
\hline 80 & Cant.1 & Cant. 2 & Cant. 3 & Cant. 4 & Cant. 5 & Cant. 6 & Cant. 7 & Cant. 8 & Cant. 9 & Cant. 10 & Cant. 11 & Cant. 12 \\
\hline Va & NPK & $\begin{array}{c}\text { NPK + } \\
\text { C }\end{array}$ & $\mathrm{F}(120 \mathrm{~kg})$ & $\begin{array}{c}F(120 \mathrm{~kg}) \\
+C\end{array}$ & $\begin{array}{c}\mathrm{F}(60 \mathrm{~kg}) \\
+ \\
\mathrm{B}(80 \mathrm{~kg})\end{array}$ & $\begin{array}{c}\mathrm{F}(60 \mathrm{~kg}) \\
+ \\
\mathrm{B}(80 \mathrm{~kg}) \\
+\mathrm{C} \\
\end{array}$ & $\begin{array}{c}\mathrm{F}(20 \mathrm{~kg}) \\
+ \\
\mathrm{B}(80 \mathrm{~kg})\end{array}$ & $\begin{array}{c}\mathrm{F}(20 \mathrm{~kg}) \\
+ \\
\mathrm{B}(80 \mathrm{~kg}) \\
+\mathrm{C}\end{array}$ & $\mathrm{B}(120 \mathrm{~kg})$ & $\begin{array}{l}\mathrm{B}(120 \mathrm{~kg}) \\
+\mathrm{C}\end{array}$ & $\begin{array}{c}\mathrm{DF}(120 \\
\mathrm{kg})\end{array}$ & $\mathrm{L}$ \\
\hline $1^{\circ} \mathrm{AF}$ & 34,9 & 49,1 & 36,1 & 213,9 & 67,4 & 126,3 & 44,4 & 47,5 & 59,6 & 72,0 & 34,8 & 8,2 \\
\hline $2^{\circ} \mathrm{AF}$ & 41,9 & 95,3 & 46,9 & 178,4 & 79,1 & 70,7 & 60,2 & 43,3 & 54,6 & 82,5 & 47,5 & $-2,1$ \\
\hline Med. AF & 38,4 & 72,2 & 41,5 & 196,2 & 73,2 & 98,5 & 52,3 & 45,4 & 57,1 & 77,2 & 41,2 & 3,1 \\
\hline
\end{tabular}


Tabela 3. 11 - Medidas de altura (H), largura (L) e comprimento (C) do terceiro plantio no decorrer de 28/11/2015 a 28/01/2016. Com os valores de L e C é possível calcular a área foliar (AF).

\begin{tabular}{|c|c|c|c|c|c|c|c|c|c|c|c|c|}
\hline \multicolumn{13}{|c|}{ Terceiro plantio - $1^{\circ}$ mês de desenvolvimento } \\
\hline Ae. & Cant.1 & Cant. 2 & Cant. 3 & Cant. 4 & Cant. 5 & Cant. 6 & Cant. 7 & Cant. 8 & Cant. 9 & Cant. 10 & $\begin{array}{l}\text { Cant. } \\
11\end{array}$ & Cant. 12 \\
\hline 象 & NPK & $\mathrm{NPK}+\mathrm{C}$ & $\mathrm{F}(120 \mathrm{~kg})$ & $\begin{array}{c}\mathrm{F}(120 \mathrm{~kg}) \\
+\mathrm{C}\end{array}$ & $\begin{array}{c}\mathrm{F}(60 \mathrm{~kg}) \\
+ \\
\mathrm{B}(80 \mathrm{~kg})\end{array}$ & $\begin{array}{c}\mathrm{F}(60 \mathrm{~kg}) \\
+ \\
\mathrm{B}(80 \mathrm{~kg}) \\
+\mathrm{C}\end{array}$ & $\begin{array}{c}\mathrm{F}(20 \mathrm{~kg})+ \\
\mathrm{B}(80 \mathrm{~kg})\end{array}$ & $\begin{array}{c}\mathrm{F}(20 \mathrm{~kg}) \\
+ \\
\mathrm{B}(80 \mathrm{~kg}) \\
+\mathrm{C}\end{array}$ & $\mathrm{B}(120 \mathrm{~kg})$ & $\begin{array}{l}\mathrm{B}(120 \mathrm{~kg}) \\
+\mathrm{C}\end{array}$ & $\begin{array}{c}\text { DF (120 } \\
\mathrm{kg})\end{array}$ & $\mathrm{L}$ \\
\hline $\mathrm{H}$ & 12,8 & 19,2 & 19,8 & 27,8 & 25,4 & 24,4 & 20,2 & 21,2 & 20,8 & 20,5 & 17,4 & 11,6 \\
\hline $\mathbf{L}$ & 4,1 & 5,6 & 4,7 & 6,8 & 6,1 & 5,9 & 5,2 & 5,9 & 4,5 & 5,6 & 5,1 & 3,4 \\
\hline C & 4,9 & 8,0 & 7,3 & 10,3 & 9,8 & 9,2 & 7,8 & 8,9 & 7,2 & 8,4 & 6,7 & 4,8 \\
\hline AF & 32,3 & 84,3 & 62,1 & 136,4 & 113,4 & 103,2 & 74,2 & 100,4 & 58,1 & 87,5 & 61,5 & 25,0 \\
\hline \multicolumn{13}{|c|}{ Terceiro plantio - $2^{\circ}$ mês de desenvolvimento } \\
\hline \multirow{2}{*}{ 象 } & Cant.1 & Cant. 2 & Cant. 3 & Cant. 4 & Cant. 5 & Cant. 6 & Cant. 7 & Cant. 8 & Cant. 9 & Cant. 10 & $\begin{array}{l}\text { Cant. } \\
11\end{array}$ & Cant. 12 \\
\hline & NPK & $\mathrm{NPK}+\mathrm{C}$ & $\mathrm{F}(120 \mathrm{~kg})$ & $\begin{array}{c}\mathrm{F}(120 \mathrm{~kg}) \\
+\mathrm{C}\end{array}$ & $\begin{array}{c}\mathrm{F}(60 \mathrm{~kg}) \\
+ \\
\mathrm{B}(80 \mathrm{~kg})\end{array}$ & $\begin{array}{c}\mathrm{F}(60 \mathrm{~kg}) \\
+ \\
\mathrm{B}(80 \mathrm{~kg}) \\
+\mathrm{C}\end{array}$ & $\begin{array}{c}\mathrm{F}(20 \mathrm{~kg})+ \\
\mathrm{B}(80 \mathrm{~kg})\end{array}$ & $\begin{array}{c}\mathrm{F}(20 \mathrm{~kg}) \\
+ \\
\mathrm{B}(80 \mathrm{~kg}) \\
+\mathrm{C}\end{array}$ & $\mathrm{B}(120 \mathrm{~kg})$ & $\begin{array}{l}B(120 \mathrm{~kg}) \\
+\mathrm{C}\end{array}$ & $\begin{array}{c}\text { DF (120 } \\
\text { kg) }\end{array}$ & $\mathrm{L}$ \\
\hline H & 12,2 & 42,6 & 37,0 & 47,8 & 55,6 & 49,6 & 42,2 & 50,6 & 36,6 & 46,0 & 12,8 & 14,6 \\
\hline $\mathbf{L}$ & 2,7 & 6,4 & 6,2 & 7,9 & 8,0 & 7,6 & 6,8 & 8,5 & 6,8 & 7,7 & 4,3 & 3,5 \\
\hline $\mathbf{C}$ & 3,6 & 9,4 & 9,2 & 11,6 & 11,0 & 10,6 & 9,4 & 11,3 & 10,5 & 11,2 & 5,7 & 5,1 \\
\hline AF & 11,4 & 115,5 & 108,5 & 179,9 & 173,8 & 157,4 & 123,0 & 188,7 & 139,1 & 170,0 & 41,8 & 27,9 \\
\hline \multicolumn{13}{|c|}{ Terceiro plantio - Média $1^{\circ}$ e $2^{\circ}$ mês } \\
\hline & Cant.1 & Cant. 2 & Cant. 3 & Cant. 4 & Cant. 5 & Cant. 6 & Cant. 7 & Cant. 8 & Cant. 9 & Cant. 10 & $\begin{array}{l}\text { Cant. } \\
11\end{array}$ & Cant. 12 \\
\hline $\mathbb{A}$ & NPK & $\mathrm{NPK}+\mathrm{C}$ & $F(120 \mathrm{~kg})$ & $\begin{array}{c}F(120 \mathrm{~kg}) \\
+C\end{array}$ & $\begin{array}{c}\mathrm{F}(60 \mathrm{~kg}) \\
+ \\
\mathrm{B}(80 \mathrm{~kg})\end{array}$ & $\begin{array}{c}\mathrm{F}(60 \mathrm{~kg})+ \\
\mathrm{B}(80 \mathrm{~kg})+ \\
C\end{array}$ & $\begin{array}{c}\mathrm{F}(20 \mathrm{~kg}) \\
+ \\
\mathrm{B}(80 \mathrm{~kg})\end{array}$ & $\begin{array}{c}\mathrm{F}(20 \mathrm{~kg}) \\
+ \\
\mathrm{B}(80 \mathrm{~kg}) \\
+\mathrm{C}\end{array}$ & $\mathrm{B}(120 \mathrm{~kg})$ & $\begin{array}{l}\mathrm{B}(120 \mathrm{~kg}) \\
+\mathrm{C}\end{array}$ & $\begin{array}{c}\text { DF (120 } \\
\text { kg) }\end{array}$ & L \\
\hline $1^{\circ} \mathrm{AF}$ & 32,3 & 84,3 & 62,1 & 136,4 & 113,4 & 103,2 & 74,2 & 100,4 & 58,1 & 87,5 & 61,5 & 25,0 \\
\hline $2^{\circ} \mathrm{AF}$ & 45,2 & 115,5 & 108,5 & 179,9 & 173,8 & 157,4 & 123,0 & 188,7 & 139,1 & 170,0 & 69,7 & 27,9 \\
\hline Med. AF & 38,7 & 99,9 & 85,3 & 158,2 & 143,6 & 130,3 & 98,6 & 144,6 & 98,6 & 128,7 & 65,6 & 26,5 \\
\hline
\end{tabular}

No primeiro plantio é possível verificar no gráfico da Figura 3.45 que há um aumento significativo na área foliar do primeiro para o segundo mês. Isto é justificado pelo maior desenvolvimento das plantas no decorrer deste período, com o aumento das folhas bem como de outras partes como o caule e a formação de flores e vagens. A exceção fica para os canteiros 9 e 10 que sofreram influência de pragas e tiveram suas dimensões bastante reduzidas no segundo período de medida.

Analisando os pontos relacionados à média das duas medidas (Figura 3.45) percebe-se que todos os canteiros com uso do fosforito apresentaram taxas bastante superiores de área foliar (de $67,3 \mathrm{~cm}^{2}$ a $111,1 \mathrm{~cm}^{2}$ ) se comparado com áreas fertilizadas com uso exclusivo de basalto (com ou sem calagem) e com dolomito fosfatado os quais tiveram área foliar variando de 26,2 $\mathrm{cm}^{2}$ a $30,4 \mathrm{~cm}^{2}$. Vale lembrar que estes valores mais baixos devem-se também a pragas que afetaram a plantação no segundo mês nos canteiros 9 e 10 . 
Nesta etapa, outra conclusão importante é correlacionada ao uso da técnica de calagem (Figura 3.45) onde nota-se que a resposta do fertilizante solúvel (canteiro 1 e 2) é totalmente dependente do método da calagem sendo que a área foliar sobe de $36,3 \mathrm{~cm}^{2}$ para $97,3 \mathrm{~cm}^{3}$. Já a rochagem apresenta uma menor dependência do processo de calagem.

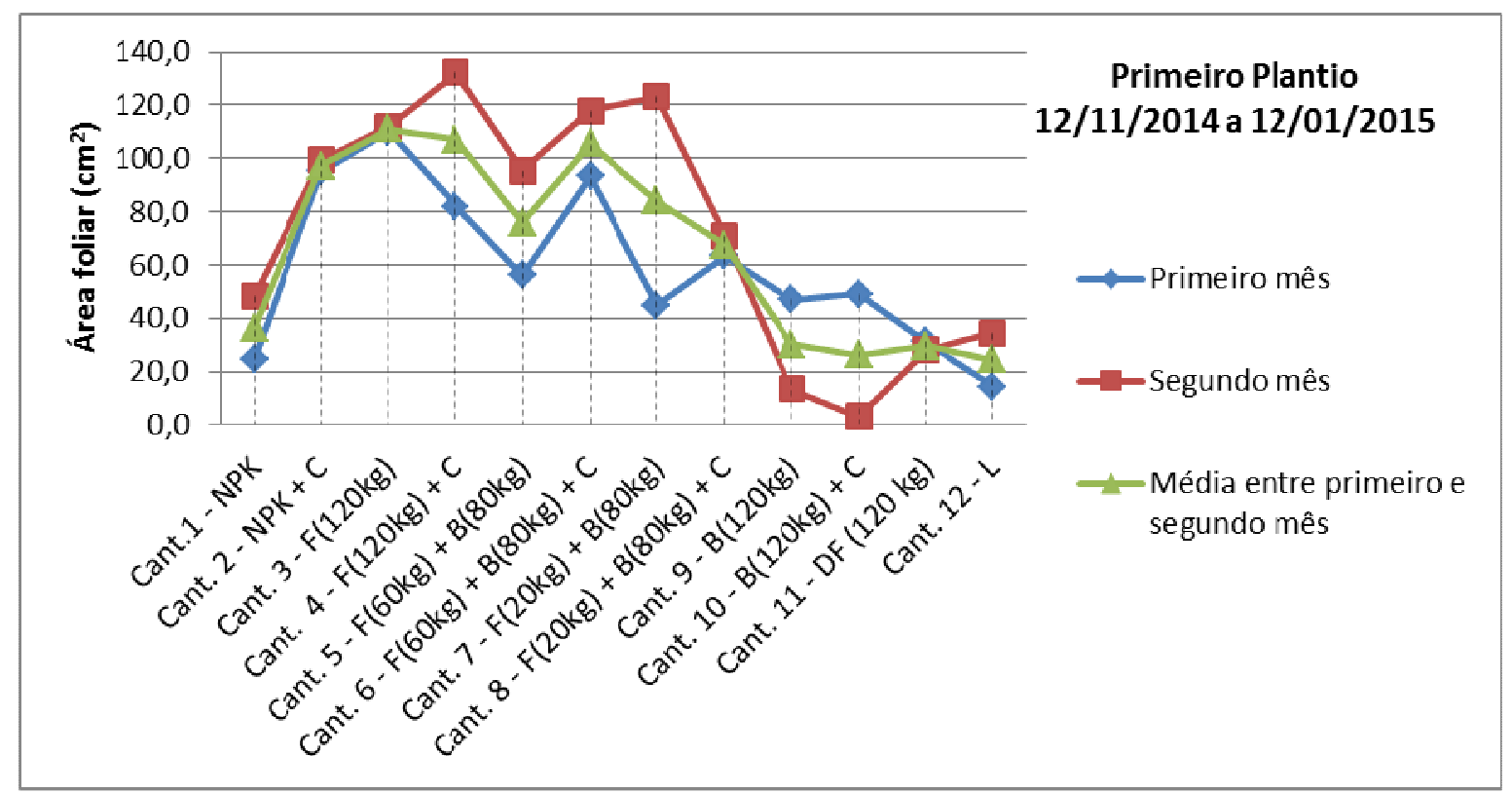

Figura 3.45 - Gráfico com as medidas de área foliar para o segundo plantio. Notar melhores resultados agronômicos dos canteiros onde apresentam fosforito. Além disso, percebe-se a grande dependência do fertilizante solúvel (NPK) ao método da calagem.

Na Figura 3.46 estão dispostas as fotos de cada canteiro após dois meses do plantio. Nestas imagens é possível verificar de forma visual que o melhor desenvolvimento está relacionado com os maiores valores de área foliar. Ainda visualiza-se que os plantios com adição de fosforito $(3,4,5,6,7,8)$ e o plantio com NPK com calagem (2) apresentaram uma melhor resposta agronômica. 


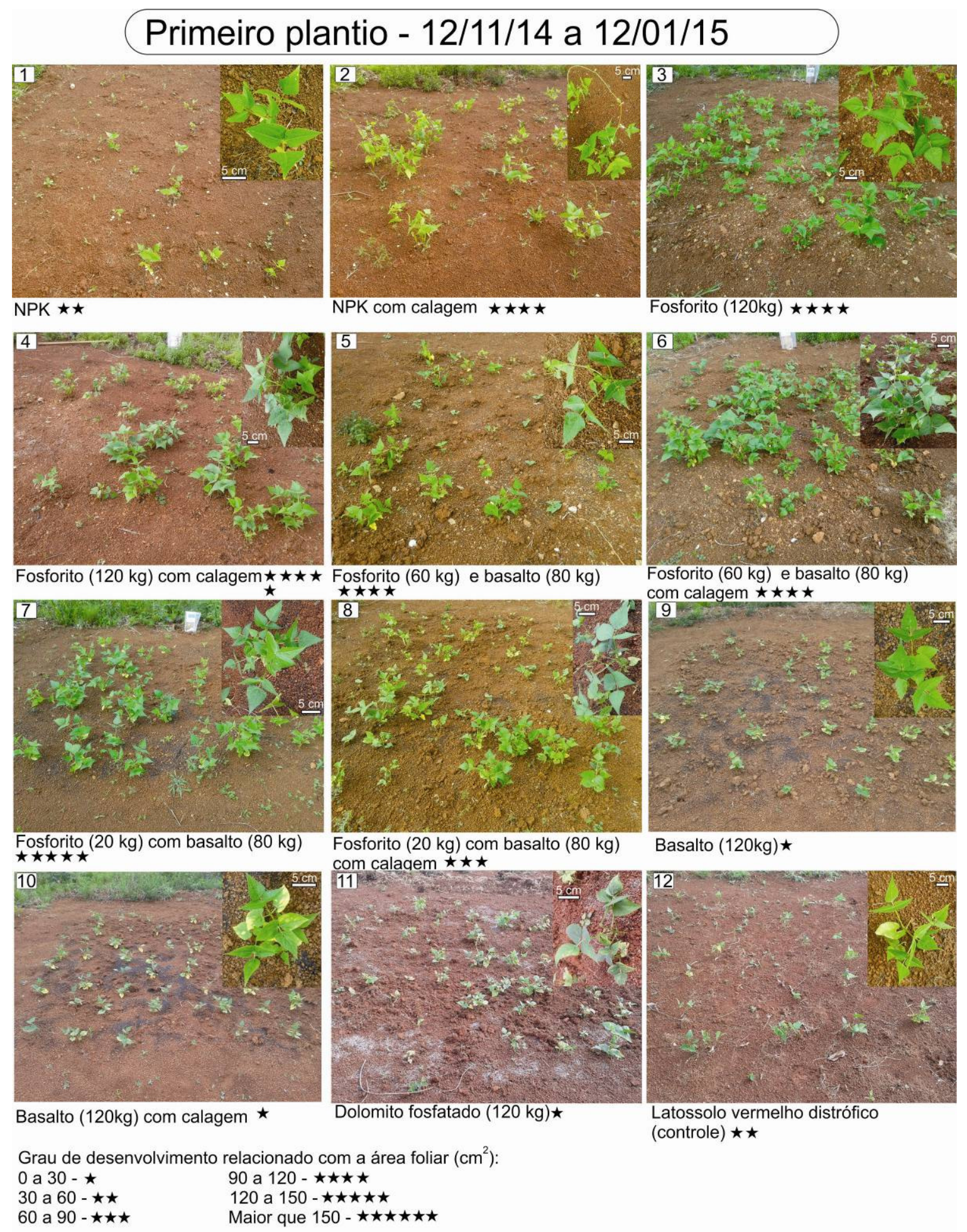

Figura 3.46 - Notar a melhor resposta agronômica dos canteiros associados com fosforito $(3,4,5,6,7,8)$ e NPK com calagem (2). Os canteiros com uso exclusivo de basalto (9 e 10) foram prejudicados por ataques de pragas ainda que não tivessem um desempenho muito significativo anteriormente. Verifica-se também um baixo desenvolvimento relacionado ao NPK sem calagem (1), dolomito fosfatato (11) e ao Latossolo controle (12).

No segundo plantio, onde as medições foram realizadas no período de março a maio de 2015, a comparação entre o primeiro e o segundo mês apresentam resultados semelhantes, inclusive com alguns picos do primeiro mês maior que do segundo, possivelmente, devido ao rápido desenvolvimento no primeiro mês e atuação de pequenas pragas e ressecamento de determinadas folhas que acarretaram na diminuição da área foliar (Figura 3.47). 
Analisando a média entre primeiro e o segundo mês (Figura 3.47) observa-se que o uso da calagem em conjunto com a rochagem traz melhores resultados agronômicos que o uso exclusivo da rochagem como é notado na comparação entre os canteiros $3\left(41,5 \mathrm{~cm}^{2}\right)$ e $4(196,2$ $\left.\mathrm{cm}^{2}\right) ; 5\left(73,2 \mathrm{~cm}^{2}\right)$ e $6\left(98,5 \mathrm{~cm}^{2}\right)$ e $9\left(57,1 \mathrm{~cm}^{2}\right)$ e $10\left(77,2 \mathrm{~cm}^{2}\right)$. A única exceção é na comparação entre os canteiros $7\left(52,3 \mathrm{~cm}^{2}\right)$ e $8\left(45,4 \mathrm{~cm}^{2}\right)$, ainda que a variação da área foliar seja pequena.

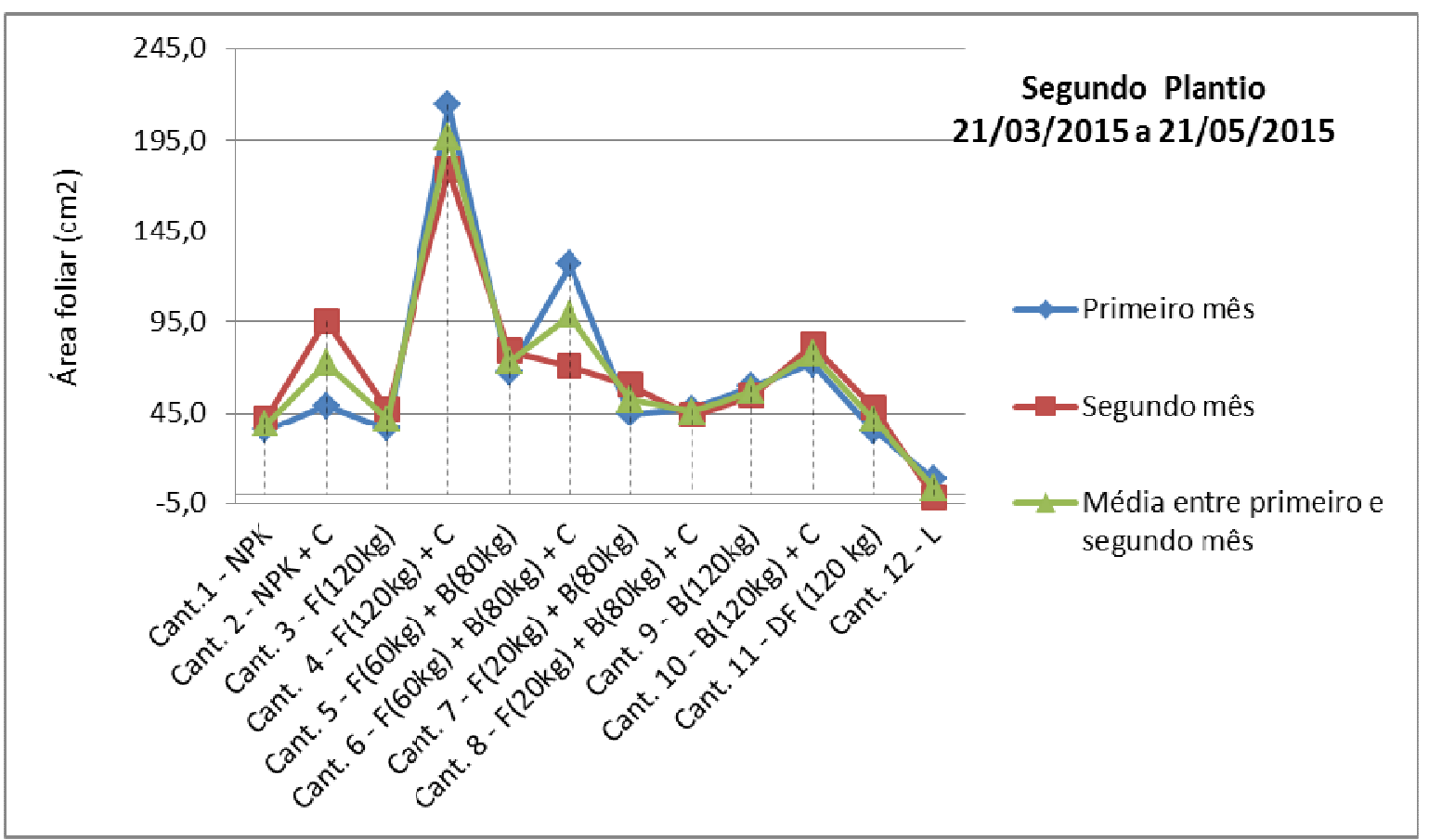

Figura 3.47 - Gráfico com as medidas de área foliar para o segundo plantio. A diferença da área foliar do primeiro para o segundo mês é mínima, devido ao ressecamento de algumas folhas e atuação de pequenas pragas. Neste gráfico é importante notar que o uso da rochagem com calagem apresenta, em sua maioria, resultados superiores ao uso exclusivo da rochagem.

A Figura 3.48 é uma compilação de fotos dos canteiros após dois meses do plantio. Nela podem-se comprovar de forma visual os dados já explanados e notar a importância do uso da calagem para o melhor desenvolvimento das plantas. 


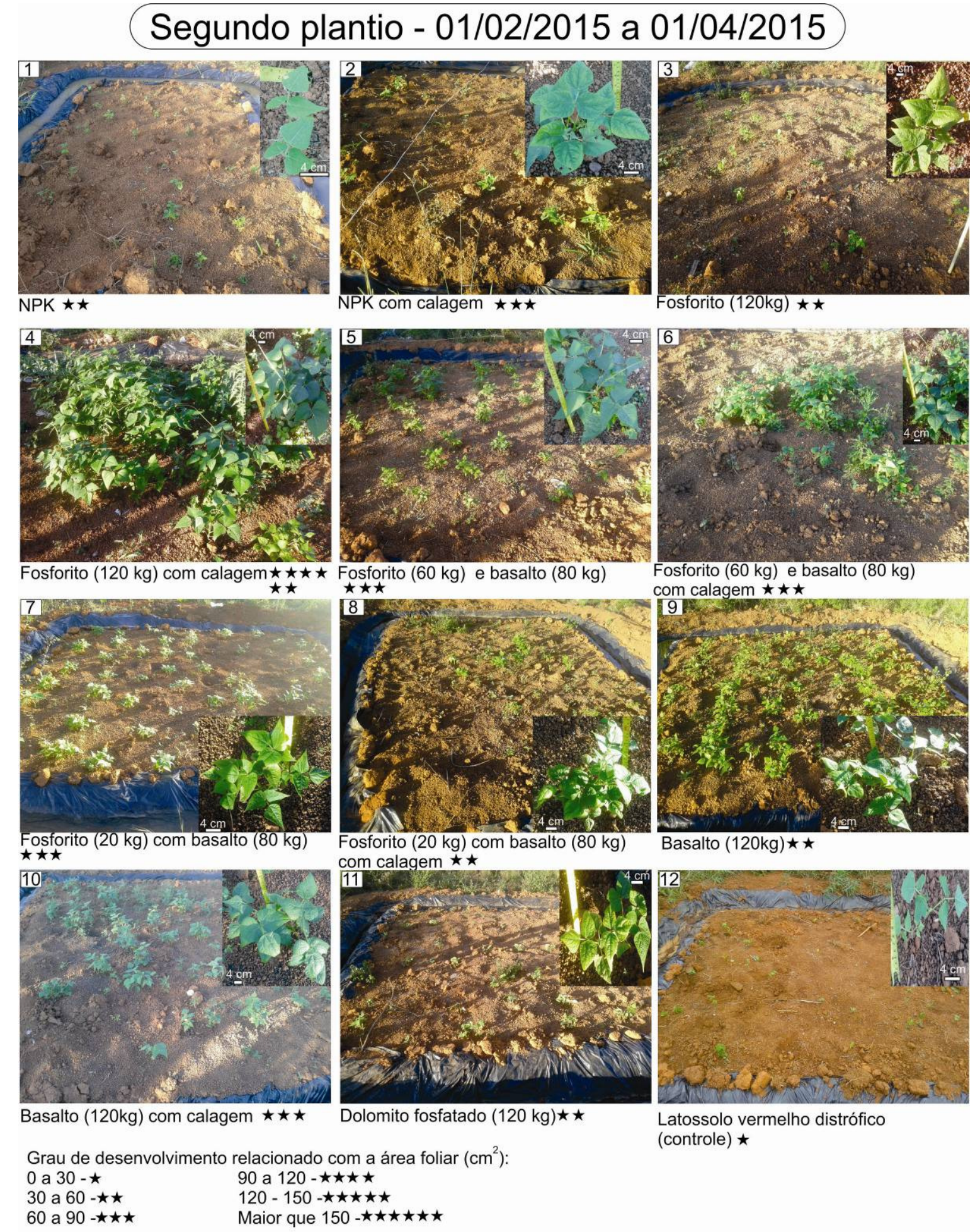

Figura 3. 48 - Compilação de fotografias que mostram o desenvolvimento das plantas no decorrer de 2 meses. Notar que, de forma geral, os canteiros que possuem rochagem e calagem apresentaram melhor desenvolvimento que os sem calagem.

O terceiro plantio ocorreu entre os meses de novembro e fevereiro de 2015/2016 e apresentou resultados importantes, pois a ocorrência de pragas foi quase insignificante nos dois primeiros meses do experimento. 
No gráfico da Figura 3.49, verifica-se um aumento significativo da área foliar quando comparado o primeiro e o segundo mês. A exceção fica para os canteiros 1,11 e 12 devido ao fraco desenvolvimento das plantas nestes canteiros e consequente estagnação do crescimento.

A relação do uso de calagem e área foliar é similar ao do segundo plantio, onde a resposta agronômica dos canteiros com calagem é superior aos casos sem a aplicação do carbonato de cálcio e magnésio. À única exceção é quando se compara os canteiros $5\left(113,4 \mathrm{~cm}^{2}\right)$ e $6(103,2$ $\left.\mathrm{cm}^{2}\right)$.

Outra análise importante é que os canteiros com maior proporção de basalto (7, 8, 9 e 10) apresentaram significativo aumento em sua área foliar se confrontado com os plantios anteriores. Além disso, a resposta agronômica destes canteiros é comparável às porções com maiores teores de fosforito (3, 4, 5 e 6) e de NPK com calagem (2). Isto pode estar relacionado com uma liberação tardia dos nutrientes presentes nas rochas máficas se comparado com o fosforito e o fertilizante solúvel.

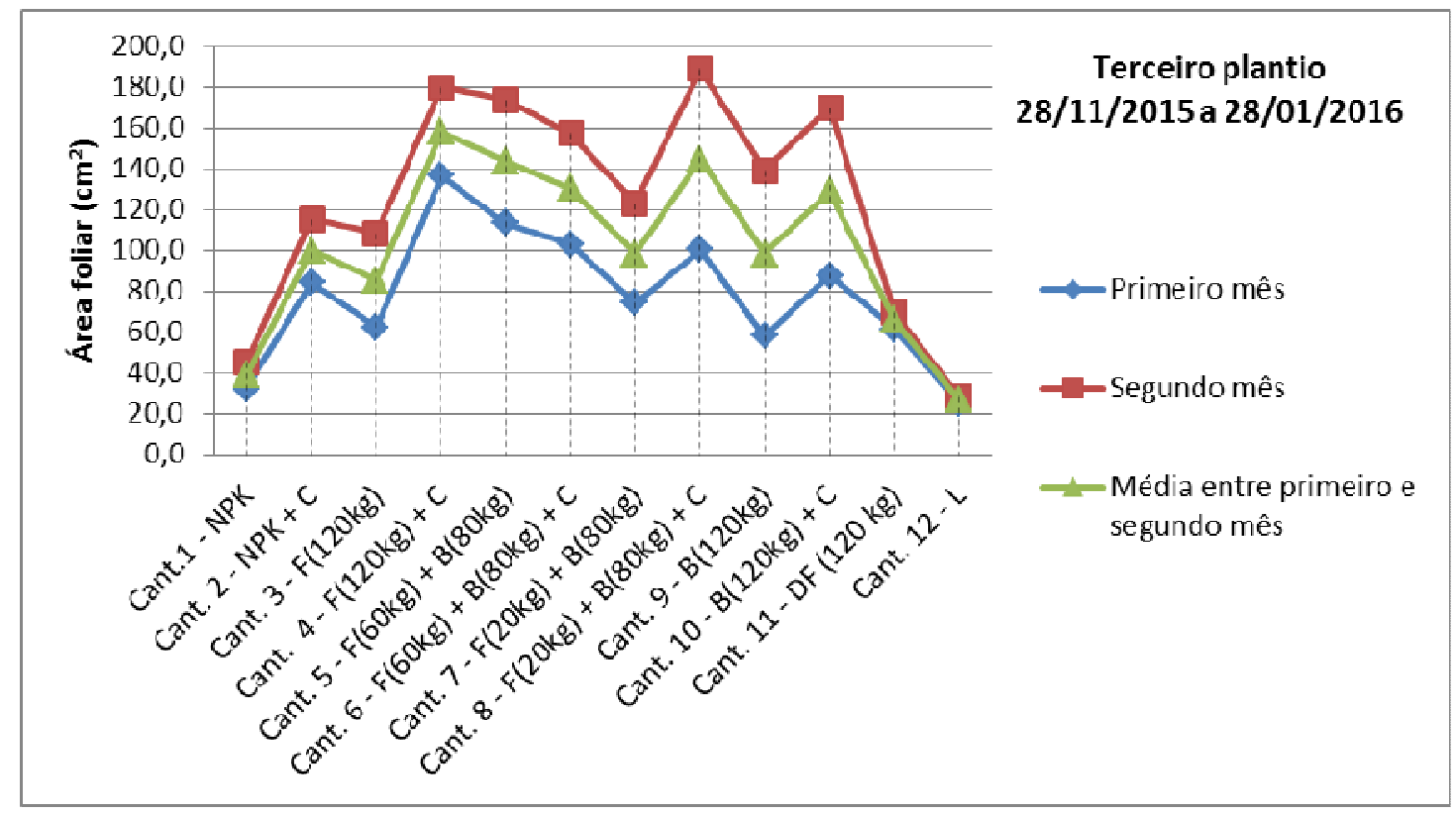

Figura 3. 49 - Neste gráfico nota-se que o uso da calagem apresenta resultados superiores aos dos insumos sem calagem com exceção dos canteiros 5 e 6 . Além disso, a resposta agronômica dos canteiros com elevada proporção de basalto $(7,8,9$ e 10) é similar às porções com maiores teores de fosforito $(3,4$, 5 e 6) e de NPK com calagem (2). Isto pode estar relacionado com uma liberação tardia dos nutrientes presentes nas rochas máficas se comparado com o fosforito e o fertilizante solúvel.

Por fim, vale ressaltar a relativa baixa resposta agronômica do uso do dolomito fosfatado (DF) (11) e do NPK sem calagem (1), os quais apresentam resultados sistematicamente baixos no decorrer dos três plantios. Isto ocorre, pois o DF não apresenta quantidade significativa de outros macronutrientes além de Mg e Ca, já o NPK sem calagem ainda que possa apresentar os nutrientes necessários para o desenvolvimento da planta, não possui $\mathrm{pH}$ adequado. Estes dois insumos apresentam resultados superiores somente ao do Latossolo controle (canteiro 12). Estas observações podem ser verificadas de forma visual na compilação de fotos apresentadas na Figura 3.50. 


\section{Terceiro plantio - 28/11/2015 a 28/01/2016}
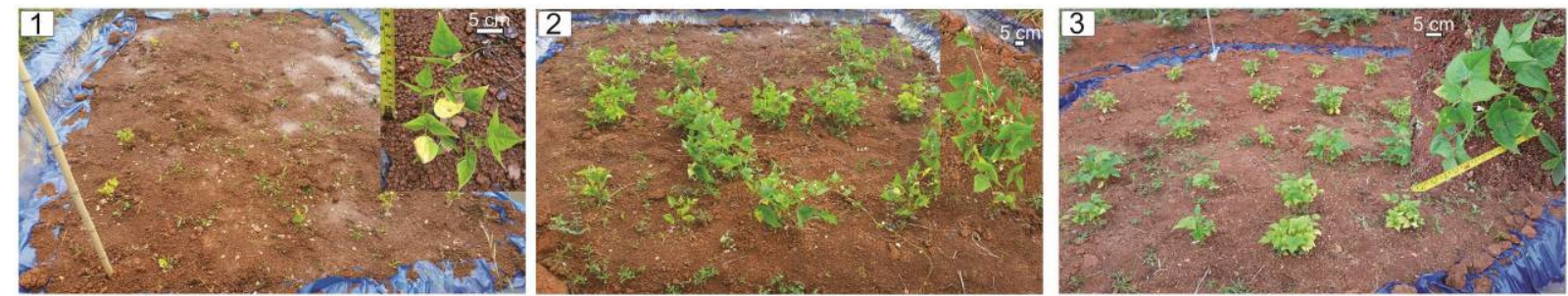

NPK $\star \star$

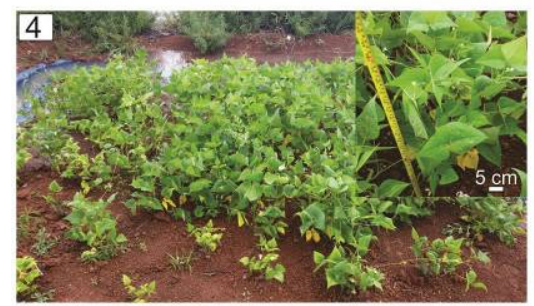

Fosforito $(120 \mathrm{~kg})$ com calagem $\star \star \star \star \star \star$

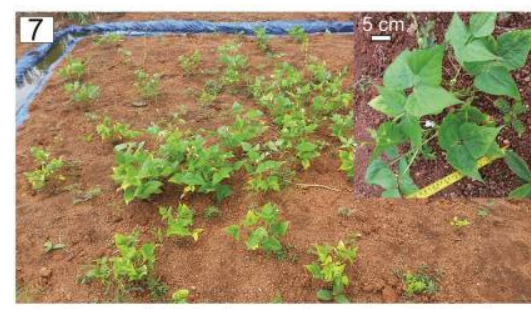

Fosforito $(20 \mathrm{~kg}$ ) com basalto (80 kg)

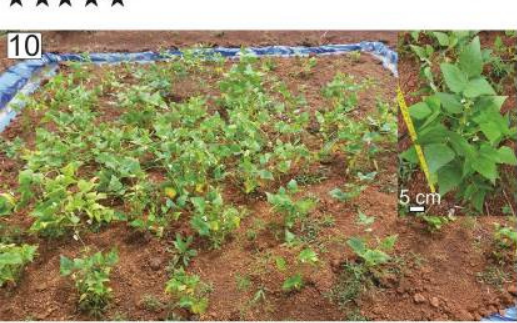

Basalto $(120 \mathrm{~kg})$ com calagem

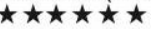

Grau de de

0 a $30-\star$

30 a $60-\star \star$

60 a $90-\star \star \star$
NPK com calagem $\star \star \star \star$

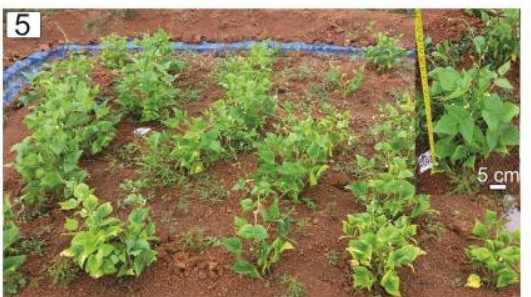

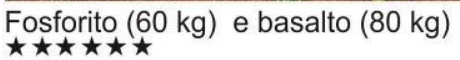

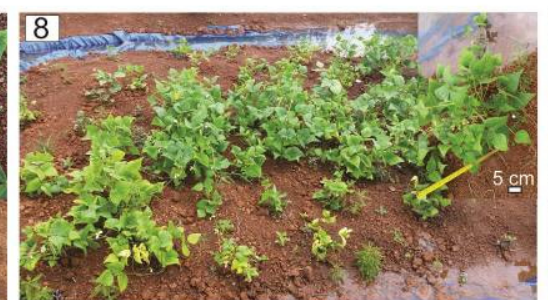

Fosforito $(20 \mathrm{~kg})$ com basalto $(80 \mathrm{~kg})$ com calagem $\star \star \star \star \star \star$

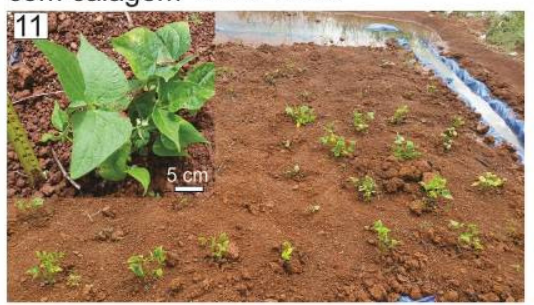

Dolomito fosfatado $(120 \mathrm{~kg}) \star \star \star$
Fosforito $(120 \mathrm{~kg}) \star \star \star \star$

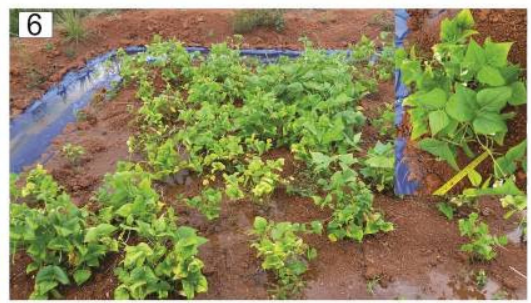

Fosforito (60 kg) e basalto (80 kg) com calagem $\star \star \star \star \star$

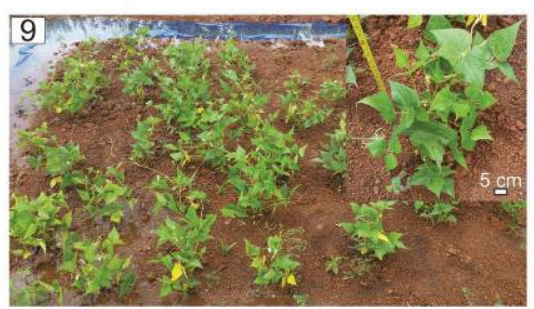

Basalto $(120 \mathrm{~kg}) \star \star \star \star \star$

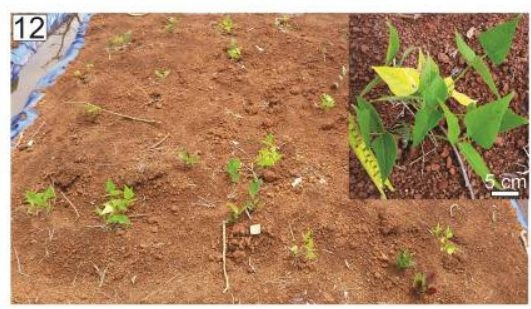

Latossolo vermelho distrófico (controle) $\star$

Figura 3. 50 - Compilação de fotos do terceiro plantio nos primeiros dois meses. Notar o bom resultado agronômico dos canteiros com rochagem, especialmente daqueles associados à calagem. Outro aspecto importante é o restrito desenvolvimento dos canteiros de dolomito fosfatado e do NPK sem calagem.

O gráfico da Figura 3.51 mostra a comparação da área foliar entre os três plantios. Notar que o uso de grande proporção de pó de basalto $(7,8,9$, e 10) apresenta um importante aumento da resposta agronômica no decorrer do experimento, apresentando no último plantio resultados agronômicos próximos aos canteiros onde existe alta proporção de fosforito $(3,4,5$ e 6$)$. Isto reforça a ideia de liberação tardia dos elementos presentes no basalto se comparado com os do fosforito. Além disso, pode-se inferir o importante efeito residual da rochagem, pois os resultados agronômicos melhoraram na última colheita. 
De modo geral, o uso do fertilizante solúvel (NPK) com calagem apresentou no transcorrer dos plantios resultados de área foliar similar ou inferior ao dos demais canteiros com rochagem. Este fato é mais marcante no terceiro plantio, onde o valor da área foliar permanece constante, enquanto a dos outros blocos apresenta aumento. Porém, vale ressaltar que a aplicação de NPK foi em tonelagem bastante inferior ao dos demais experimentos.

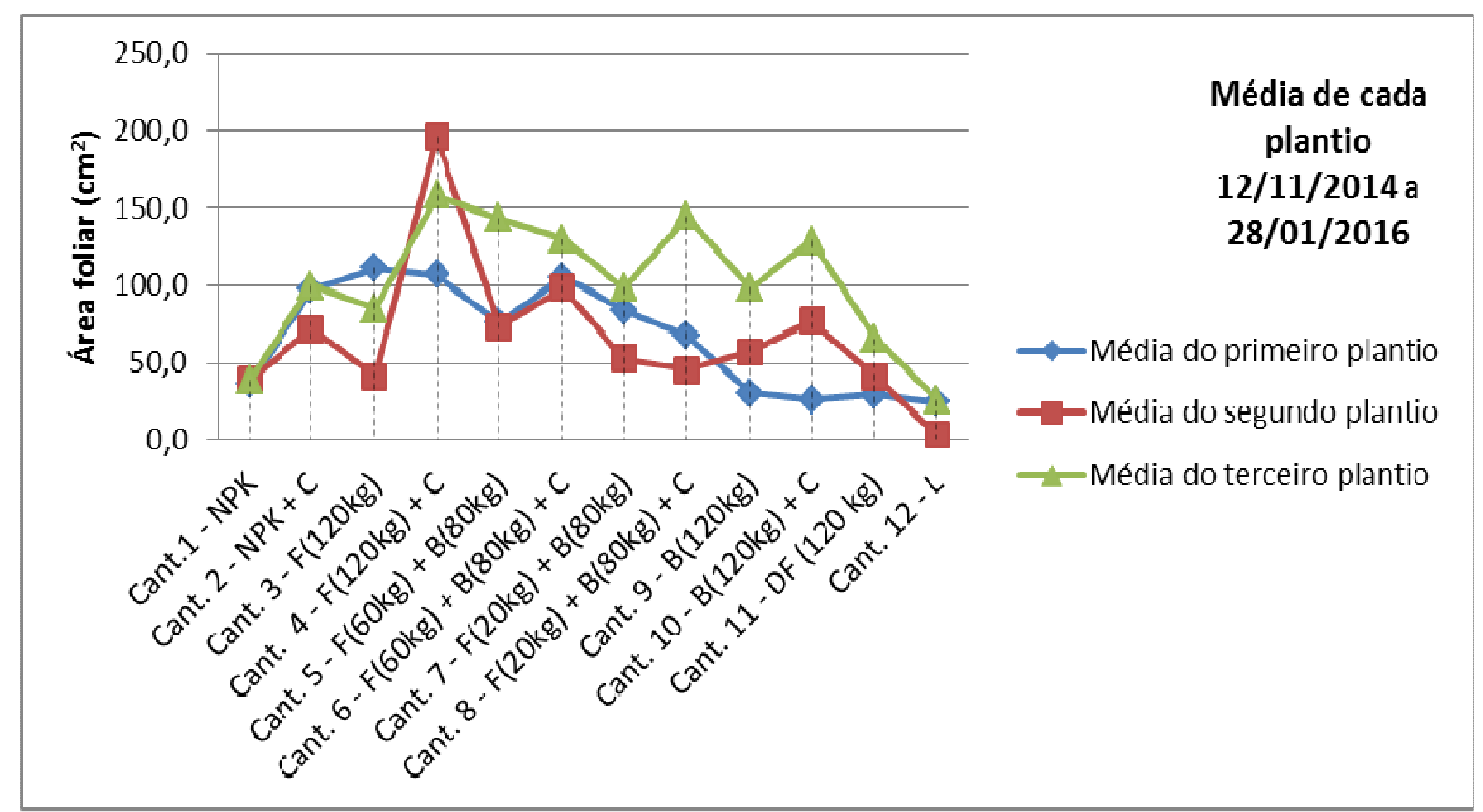

Figura 3.51 - Gráfico com a média de área foliar de cada plantio. Notar que no terceiro plantio há um aumento da área foliar se comparado com os plantios anteriores, especialmente onde foram aplicados insumos de fosforito e basalto. Os canteiros com NPK com e sem calagem, dolomito fosfatado e Latossolo controle, apresentaram medidas de área foliar mais baixas e constantes ao longo dos três plantios.

O gráfico da Figura 3.52 é uma compilação de todos os dados coletados nos três plantios. Neste gráfico nota-se que a totalidade dos canteiros em que houve a aplicação da calagem apresentou melhores resultados que os sem. Deste modo, fica evidente a importância da calagem para o desenvolvimento das plantas mesmo com o uso da rochagem.

Apesar desta constatação, é importante verificar que a calagem é muito mais importante quando se utiliza fertilizante solúvel do que nos demais métodos de rochagem, visto que a resposta agronômica exclusiva do NPK é somente superior ao do Latossolo controle. Por fim, é necessário constatar que o dolomito fosfatado apresentou baixa resposta agronômica no decorrer dos plantios, tendo somente utilidade no controle do $\mathrm{pH}$. Este fato já era esperado, pois a adição de pó de dolomito fosfatado apenas contribui de forma significativa com cálcio e magnésio, e não fornece outros macronutrientes fundamentais.

$\mathrm{O}$ uso dos demais pós de rochas, além do $\mathrm{P}, \mathrm{Ca}, \mathrm{Mg}$ ainda contribui potencialmente com $\mathrm{Na}$, K e micronutrientes. 


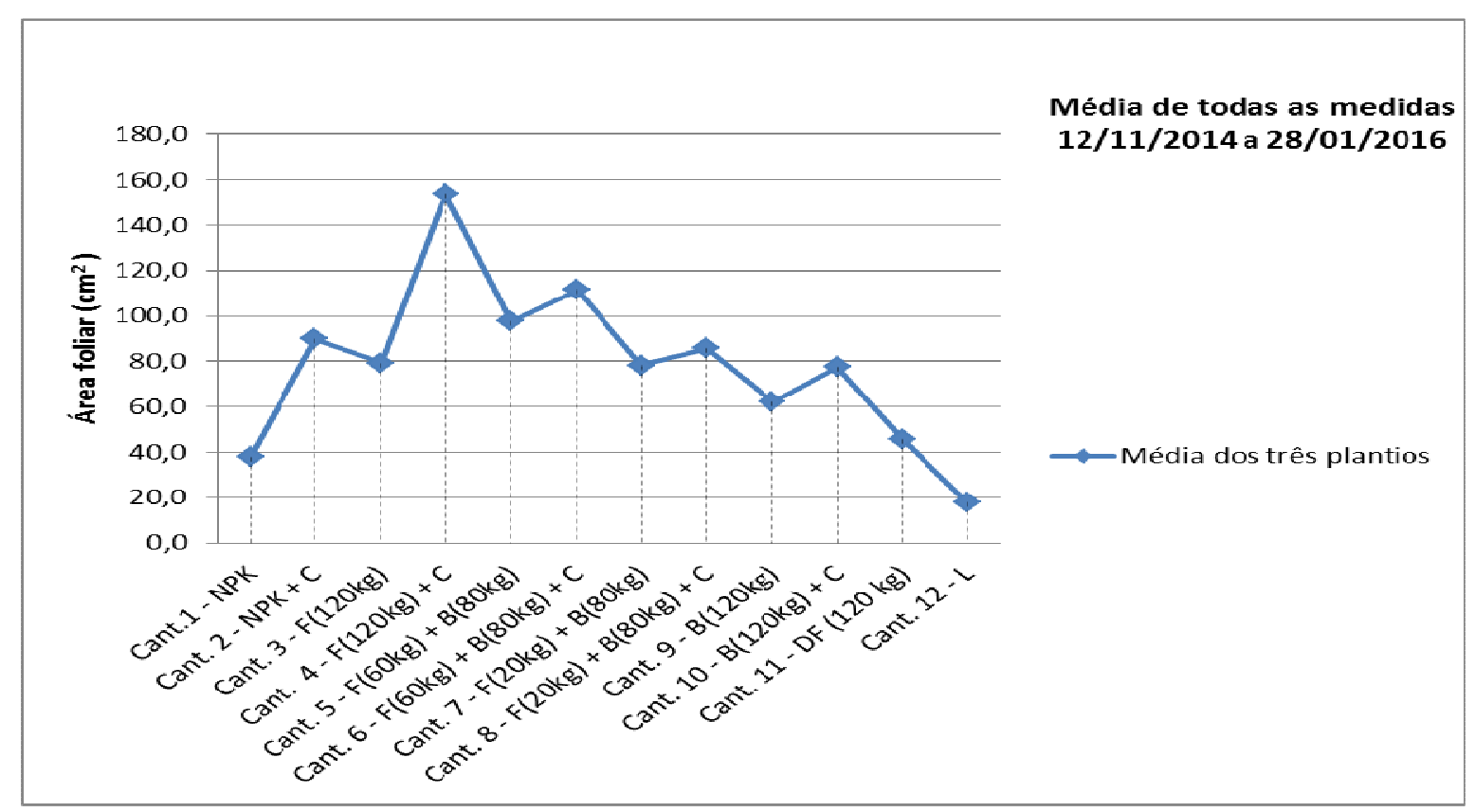

Figura 3.52 - Gráfico com a compilação de todos os dados coletados nos três plantios. Observa-se que todos os canteiros em que houve a aplicação da calagem apresentam melhores resultados que os sem. Assim sendo, é evidente a importância da calagem para o desenvolvimento das plantas mesmo com o uso da rochagem.

No terceiro plantio, houve a possibilidade de colher e pesar as plantas de cada canteiro. Realizou-se a medida de cinco plantas por canteiro, calculando o peso da massa verde (MV), o peso das vagens (PV) e o peso dos grãos de feijão (PG) (Tabela 3.12).

No cálculo do peso da massa verde, foi necessário cortar a raiz, e medir o peso da parte aérea (caule, folhas, ramos e vagens).

Tabela 3. 12 - Dados de produtividade do terceiro plantio, onde foi medida a massa verde (MV), peso da vagem $(\mathrm{PV})$ e peso dos grãos (PG).

\begin{tabular}{|c|c|c|c|c|c|c|c|c|c|c|c|c|}
\hline \multicolumn{13}{|c|}{ Medidas de peso em gramas para o terceiro plantio (28/11/2015 a 06/02/2016) } \\
\hline & Cant.1 & Cant. 2 & Cant. 3 & Cant. 4 & Cant. 5 & Cant. 6 & Cant. 7 & Cant. 8 & Cant. 9 & Cant. 10 & $\begin{array}{l}\text { Cant. } \\
11\end{array}$ & $\begin{array}{l}\text { Cant. } \\
12\end{array}$ \\
\hline & NPK & $\begin{array}{l}\mathrm{NPK}+ \\
\mathrm{C}\end{array}$ & $\mathrm{F}(120 \mathrm{~kg})$ & $\begin{array}{c}F(120 \mathrm{~kg}) \\
+C\end{array}$ & $\begin{array}{c}\mathrm{F}(60 \mathrm{~kg}) \\
+ \\
\mathrm{B}(80 \mathrm{~kg})\end{array}$ & $\begin{array}{c}\mathrm{F}(60 \mathrm{~kg}) \\
+ \\
\mathrm{B}(80 \mathrm{~kg}) \\
+\mathrm{C}\end{array}$ & $\begin{array}{c}\mathrm{F}(20 \mathrm{~kg}) \\
+ \\
\mathrm{B}(80 \mathrm{~kg})\end{array}$ & $\begin{array}{c}\mathrm{F}(20 \mathrm{~kg}) \\
+ \\
\mathrm{B}(80 \mathrm{~kg}) \\
+\mathrm{C}\end{array}$ & $\mathrm{B}(120 \mathrm{~kg})$ & $\begin{array}{l}\mathrm{B}(120 \mathrm{~kg}) \\
+\mathrm{C}\end{array}$ & $\begin{array}{c}\text { DF } \\
(120 \\
\mathrm{kg})\end{array}$ & $\mathrm{L}$ \\
\hline MV & 1,0 & 40,2 & 15,3 & 71,2 & 99,8 & 96,6 & 45,6 & 87,0 & 23,6 & 47,8 & 3,3 & 2,2 \\
\hline PV & 0,0 & 22,4 & 8,5 & 39,0 & 49,2 & 46,2 & 23,2 & 39,2 & 19,0 & 24,2 & 0,0 & 0,0 \\
\hline PG & 0,0 & 7,2 & 3,0 & 19,6 & 15,0 & 20,2 & 7,6 & 11,6 & 7,2 & 9,2 & 0,0 & 0,0 \\
\hline
\end{tabular}

No gráfico da Figura 3.53, são plotados os pesos de MV, PV e PG os quais apresentam comportamento semelhante. Estes dados reforçam a ideia da necessidade de calagem para o pleno desenvolvimento das plantas. Nota-se também que o uso do fosforito é o insumo que apresenta melhores resultados especialmente quando associado a calagem e/ou basalto (canteiros $4,5,6,7$, e 8$)$. 
Os canteiros de NPK com calagem (2) e basalto com e sem calagem (9 e 10) apresentaram resultados de produtividade moderados a baixos se comparados com as misturas ricas em fosforito. Já os canteiros de NPK sem calagem (1), dolomito fosfatado (11) e Latossolo (12) nem sequer desenvolveram vagens (Figuras 3.53 e 3.54 ).

O canteiro somente com fosforito (3) ainda que tenha sofrido com pequenas pragas, não apresentou resultado tão satisfatório quanto às misturas de pós de rocha. Isto indica que o uso exclusivo de fosforito não supre a totalidade de nutrientes das plantas.

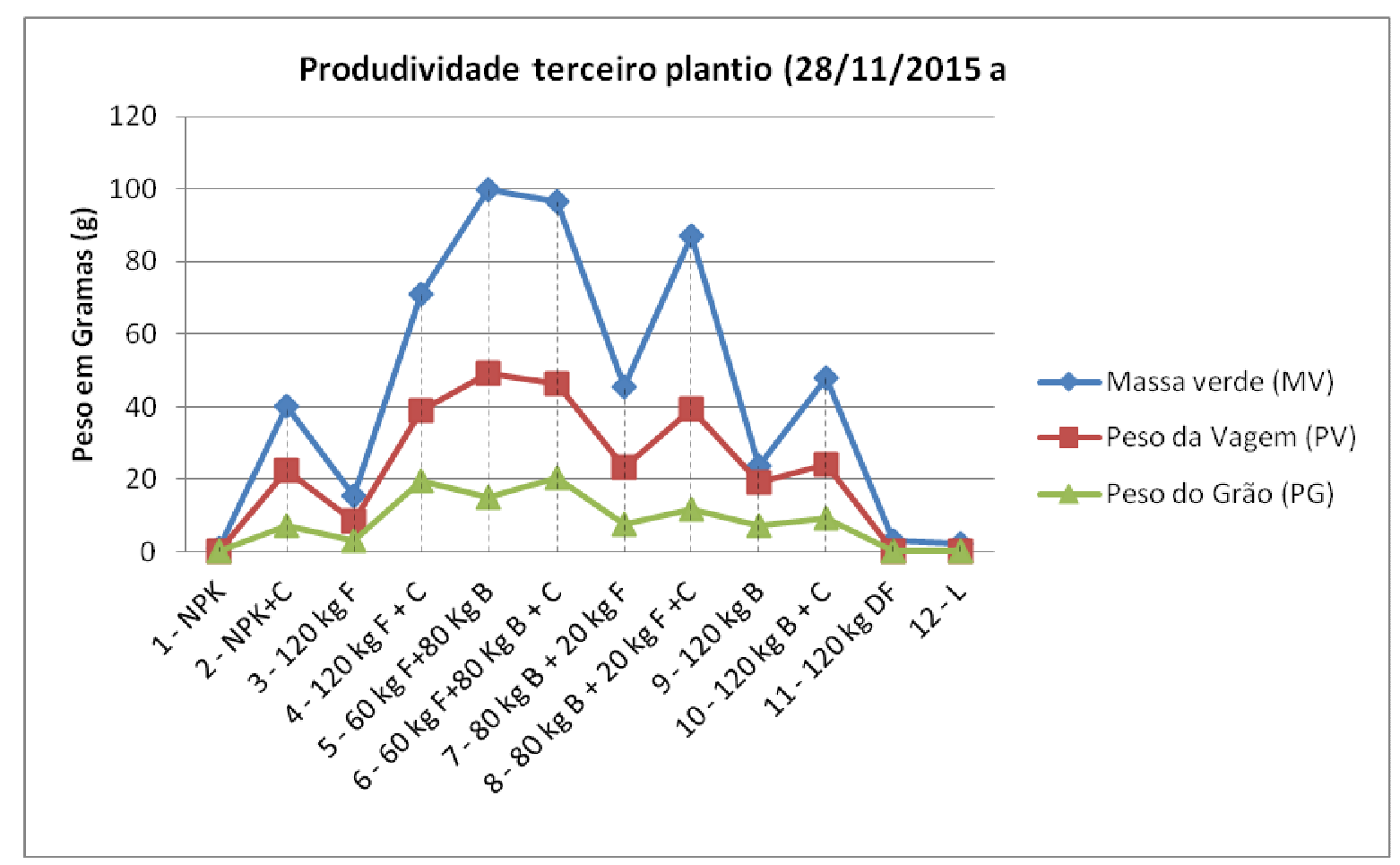

Figura 3. 53 - Gráfico com as medidas de peso da massa verde, peso da vagem e peso do grão do feijão comum. 


\section{Terceiro plantio - Peso em Gramas - 28/11/2015 a 06/02/2016}
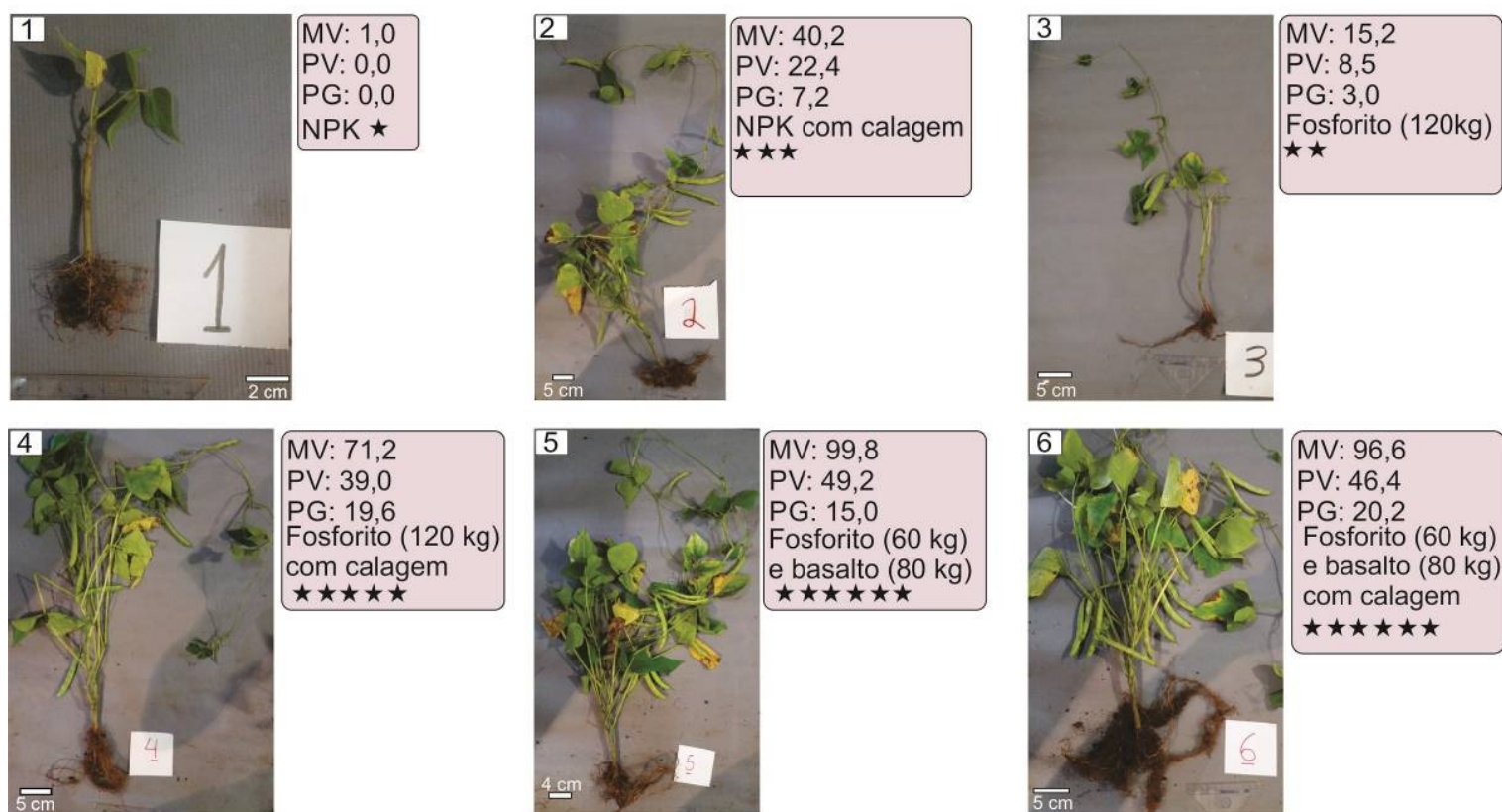

MV: 99,8

PV: 49,2

PG: 15,0

Fosforito $(60 \mathrm{~kg})$

e basalto $(80 \mathrm{~kg})$

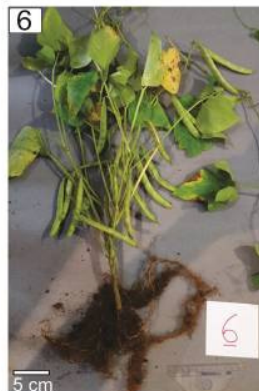

MV: 96,6

PV: 46,4

PG: 20,2

Fosforito $(60 \mathrm{~kg})$

e basalto $(80 \mathrm{~kg})$

com calagem

$\star \star \star \star \star \star$
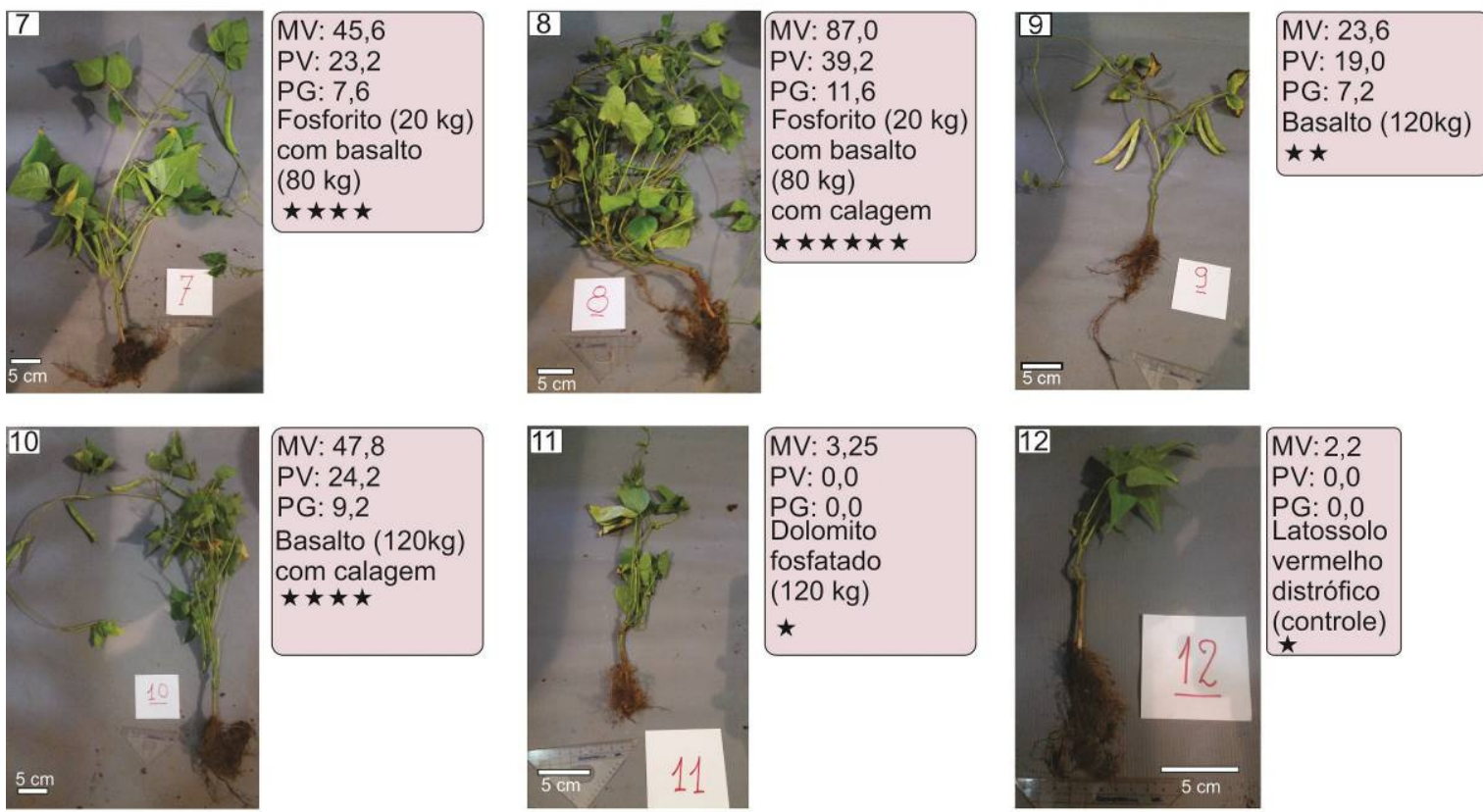

Grau de desenvolvimento relacionado com a Massa Verde (MV) (gramas(g)):
0 a $15-\star$

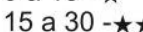
30 a $45-\star \star \star$
45 a $60-\star \star \star \star$
60 a $75-\star \star \star \star \star ~$

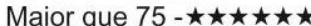

Figura 3. 54 - Compilação de fotografias das plantas de cada canteiro. Os dados de massa verde (MV), peso da vagem (PV) e peso dos grãos (PG) são obtidos pela média de cinco indivíduos (peso em gramas).

Outras observações importantes são a expressiva quantidade de micorrizas em quase todos os canteiros. As porções com menor quantidade de micorrizas são os canteiros com Latossolo (12) e NPK sem calagem (1). Já os canteiros com a maior quantidade de micorrizas são aqueles com mistura de basalto e fosforito (canteiros 6 e 7) (Figura 3.55). 

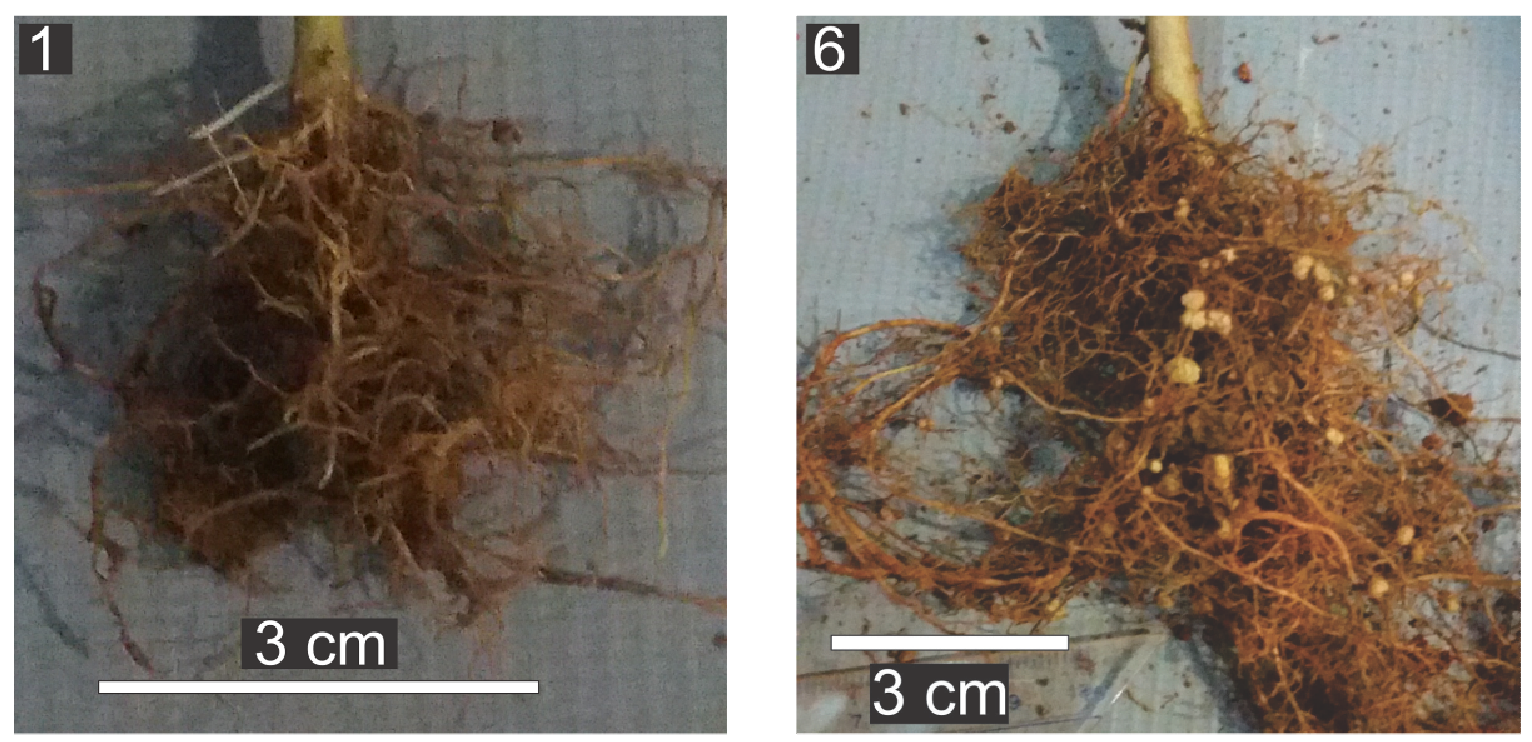

Figura 3. 55 - Fotografia comparativa do canteiro onde houve somente a utilização de NPK (Canteiro 1) com canteiro de mistura de basalto, fosforito e calagem (canteiro 6). Notar que no canteiro com utilização de rochagem (6) há uma numerosa quantidade de micorriza se confrontado com porções sem uso de pó de rocha (1).

Por fim, ainda que a descrição visual de deficiências de nutrientes seja de certo modo subjetiva e careça de precisão, é notável que em vários canteiros ocorram o amarelecimento internerval das folhas mais novas, onde as nervuras e áreas adjacentes permanecem com coloração verde-intenso. Esta característica é correlacionada normalmente à falta de manganês como é observado na Figura 3.56 (Rosolem \& Marubayashi 1994).

De modo geral, esta deficiência foi mais acentuada no canteiro 3, entretanto foram observados também nos canteiros 1, 2, 6, 11 e 12. Sendo encontrado em proporções bem menores nos demais canteiros.

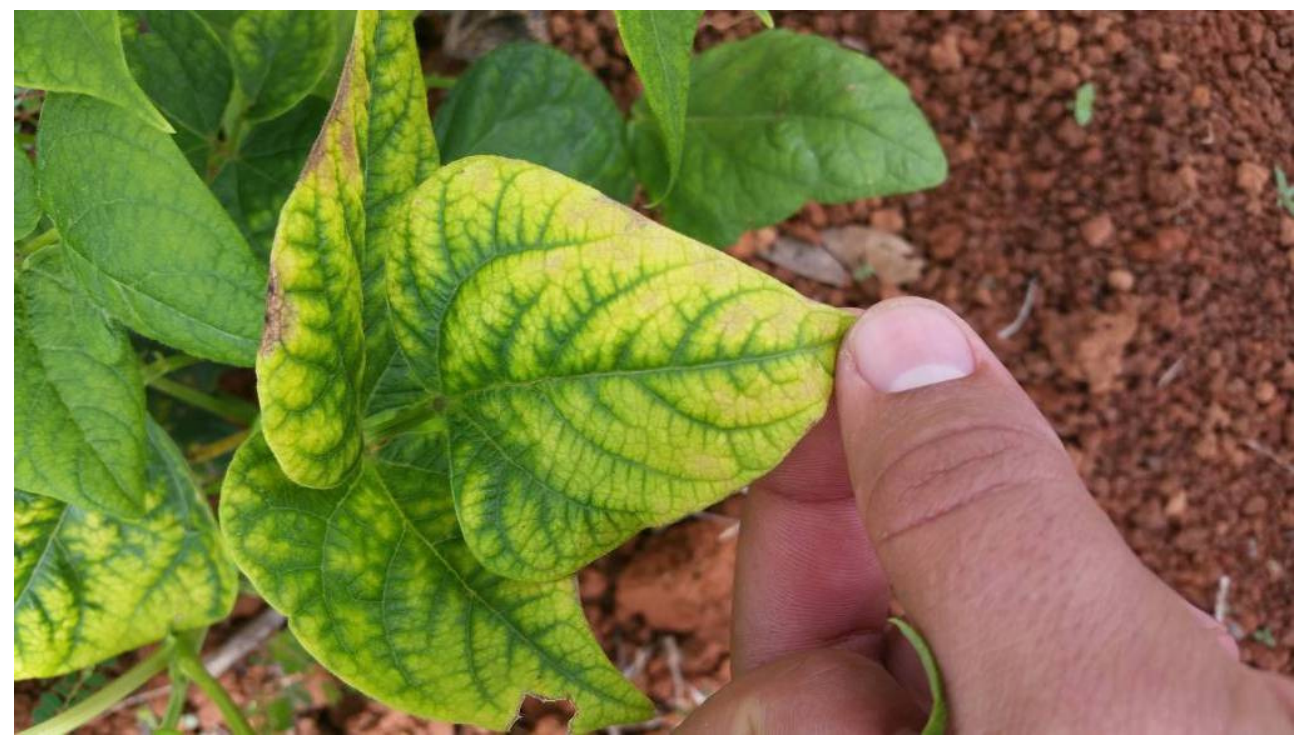

Figura 3. 56 - Evidência de deficiência de manganês (canteiro 2). Esta deficiência é caracterizada pelas folhas apresentarem as nervuras e áreas adjacentes com coloração verde-intenso. 


\subsection{Balanço Econômico Preliminar}

Leonardos et al. (1976) resumem que a rochagem pode aumentar substancialmente os níveis de nutrientes minerais dos solos por um preço economicamente realista quando a distância do material a ser transportado for pequena. Entretanto, estes autores não informam o que é considerada uma distância pequena.

Neste aspecto é importante salientar que a rochagem apresenta custo de beneficiamento reduzido, visto que muitas vezes é rejeito de pedreiras e que a necessidade de calagem é menor se comparado com ao uso de NPK comercial. A grande desvantagem do uso da rochagem é devida ao elevado volume de pó de rocha necessário, o que resulta em valor de transporte bastante elevado (Souza et al. 2013 e Souza 2014).

No presente estudo foi utilizado o preço médio de duas pedreiras de produção de pó de dolomito, que vendem a tonelada pelo valor de $\mathrm{R} \$ 37,66$ com teores de 42,33\% de $\mathrm{CaO}$ e de $8,46 \%$ de $\mathrm{MgO}$. Já o valor encontrado para o do NPK (4;30;10) granulado utilizado no experimento é de $\mathrm{R} \$ 3.470,00$ a tonelada.

Com base nos teores de óxidos dado pelas análises de fluorescência de raios-X pode-se valorar o preço por tonelada dos insumos. Para este cálculo também é importante verificar a taxa de dissolução dada pela relação dos teores dos óxidos contidos no início e no fim do experimento, assim sendo, obteve-se uma taxa de dissolução média dos óxidos de K e P para os pós de rocha utilizados de 29,4\%. Deste modo, o valor comercial por tonelada de basalto, fosforito e dolomito fosfatado poderia ser, respectivamente, de $\mathrm{R} \$ 38,87$; $\mathrm{R} \$ 221,06$ e $\mathrm{R} \$ 88,75$.

No presente estudo, a tonelagem utilizada nas parcelas plantadas foi excessiva, visto que o experimento teve um enfoque mais mineralógico e geoquímico. Entretanto, para um exercício de análise econômica, se considerarmos o uso de calcário numa proporção de 2 ton/ha e o NPK de $150 \mathrm{~kg} / \mathrm{ha}$, teremos um custo de $\mathrm{R} \$ 595,82$ por hectare (Souza et al. 2013). Com este valor, poderiam ser aplicados 15,32 ton/ha de pó de basalto ou 2,69 ton/ha de pó de rochas fosfatada solúvel, ou ainda 6,71 ton/ha de pó de dolomito fosfatado, que são volumes bastante significativos.

Ainda que na rochagem se gaste mais com o transporte do produto, este valor é compensado pelo baixo custo de beneficiamento e a menor necessidade de calagem. Além disso, é interessante considerar o valor agregado ao produto de origem agroecológica. Por exemplo, segundo Martins et al. (2006) quando se compara os preços dos produtos orgânicos com os similares convencionais, verifica-se que a diferença média de preços entre eles ficou entre $150 \%$ e $240 \%$.

Por fim, é necessário salientar que a rochagem necessita de menores quantidades de reaplicações se comparado com a fertilização convencional, devido ao seu efeito residual comentado nos tópicos anteriores e vizualidado no gráfico da Figura 3.51. 


\section{CAPÍTULO 4 \\ CONSIDERAÇÕES FINAIS}

\subsection{Conclusão e Considerações Finais}

Os dados apresentados permitem afirmar que o uso da rochagem resulta em um significativo aumento das substâncias e parâmetros físico-químicos responsáveis pela fertilidade dos solos, bem como de sua resposta agronômica, além de apresentar um importante efeito residual. Entretanto, para o pleno desenvolvimento das plantas além da utilização dos pós de basalto, fosforito ou dolomito fosfatado foi necessário o uso da calagem para potencializar seus efeitos benéficos.

Do ponto de vista da geoquímica de fertilidade do solo, importantes conclusões podem ser alcançadas. Ao contrário do consenso geral, as análises indicam que os pós de rocha podem disponibilizar de forma rápida os macronutrientes necessários para as plantas, isto é evidenciado pelos elevados teores de saturação por bases (V) antes da aplicação do material que eram de $95 \%$ para o basalto, $67 \%$ para o fosforito e de $87 \%$ para o dolomito fosfatado. Após um ano do experimento, os valores de V continuaram significativos com média de 54,4\% nos dez canteiros com aplicação das misturas de pós de rocha. Deste modo, pode-se inferir que a curto e médio prazo os nutrientes são disponibilizados de forma eficaz para as plantas. Este pensamento está de acordo com os estudos de Chesworth et al. (1983).

Além de elevar a saturação por bases observa-se, de forma geral, que os insumos oriundos da rochagem, aumentaram de forma significativa os valores de $\mathrm{pH}$ e fósforo disponível e ainda diminuíram a saturação por alumínio. Entretanto, os parâmetros de matéria orgânica e carbono tiverem seus teores reduzidos devido, provavelmente, ao consumo pelo aumento da atividade microbiana (Ernani et al. 1996 e 1998).

Utilizou-se a fluorescência de raios-X para verificar especialmente os elementos insolúveis. Deste modo, verificou-se que os pós de rocha que não foram submetidos ao método da calagem apresentaram uma diminuição de 2,4 vezes nos teores dos óxidos $\mathrm{K}, \mathrm{P}$ e S. Esta diminuição é bem mais acentuada quando se compara com os canteiros com calagem que foram de apenas 1,12 vezes. Isto significa que a disponibilidade e/ou lixiviação dos nutrientes é maior quando não se aplica rocha carbonática para a correção do pH.

Estes dados reforçam, por exemplo, as ideias de Chesworth et al. (1985), Chien \& Menon (1995) e Ernani et al. (2001) que afirmam que para rochas como o fosfato natural sua maior dissolução acontece em condições de baixo $\mathrm{pH}$.

As medições sistemáticas do $\mathrm{pH}$ em $\mathrm{H}_{2} \mathrm{O}$ e em $\mathrm{KCl}$ para todos as parcelas de plantio, mostram que o equilíbrio iônico é rico em cargas negativas ( $\Delta \mathrm{pH}$ negativo). Entretanto, o uso da 
calagem e/ou rochagem atua no sentido de aproximar estes valores de zero, diminuindo a atividade de cargas negativas na solução do solo (Raij \& Peech 1972, Tavares Filho et al. 2010 e Machado et al. 2013).

Vale lembrar, que o uso dos silicatos, ainda que não corrija de forma mais intensa os valores de $\Delta \mathrm{pH}$ apresenta a vantagem de disponibilizar o ânion silicato que concorre pelo mesmo sítio de adsorção do ânion fosfato, aumentado a disponibilidade deste último para o ambiente (Volkweiss \& Raij 1977 e Sandim et al. 2014).

Para evidenciar a importância do equilíbrio iônico, o qual pode ser dado em ponto de carga zero (PCZ) construiu-se o gráfico da Figura 4.1 que evidencia que o aumento da PCZ, especialmente ligada à calagem, coincide muito bem com os valores de maior resposta agronômica calculado pela área foliar. A medição da PCZ reflete melhor o desenvolvimento das plantas comparado inclusive com a análise da saturação por bases. Isto é verificado no gráfico da Figura 4.2 onde a correlação entre a resposta agronômica e a saturação por bases não é tão exata quanto a observada no gráfico da Figura 4.1.

Vale salientar que nestes dois gráficos é observado um comportamento diferente na parcela rica em dolomito fosfatado (11), pois neste caso, ainda que apresente elevados valores de PCZ e V possui baixa resposta agronômica (AF). Isto ocorre, uma vez que o insumo apresenta somente elevados teores de $\mathrm{CaO}$ e $\mathrm{MgO}$ sendo pobre nos demais macro e micronutrientes fundamentais para o desenvolvimento das plantas.

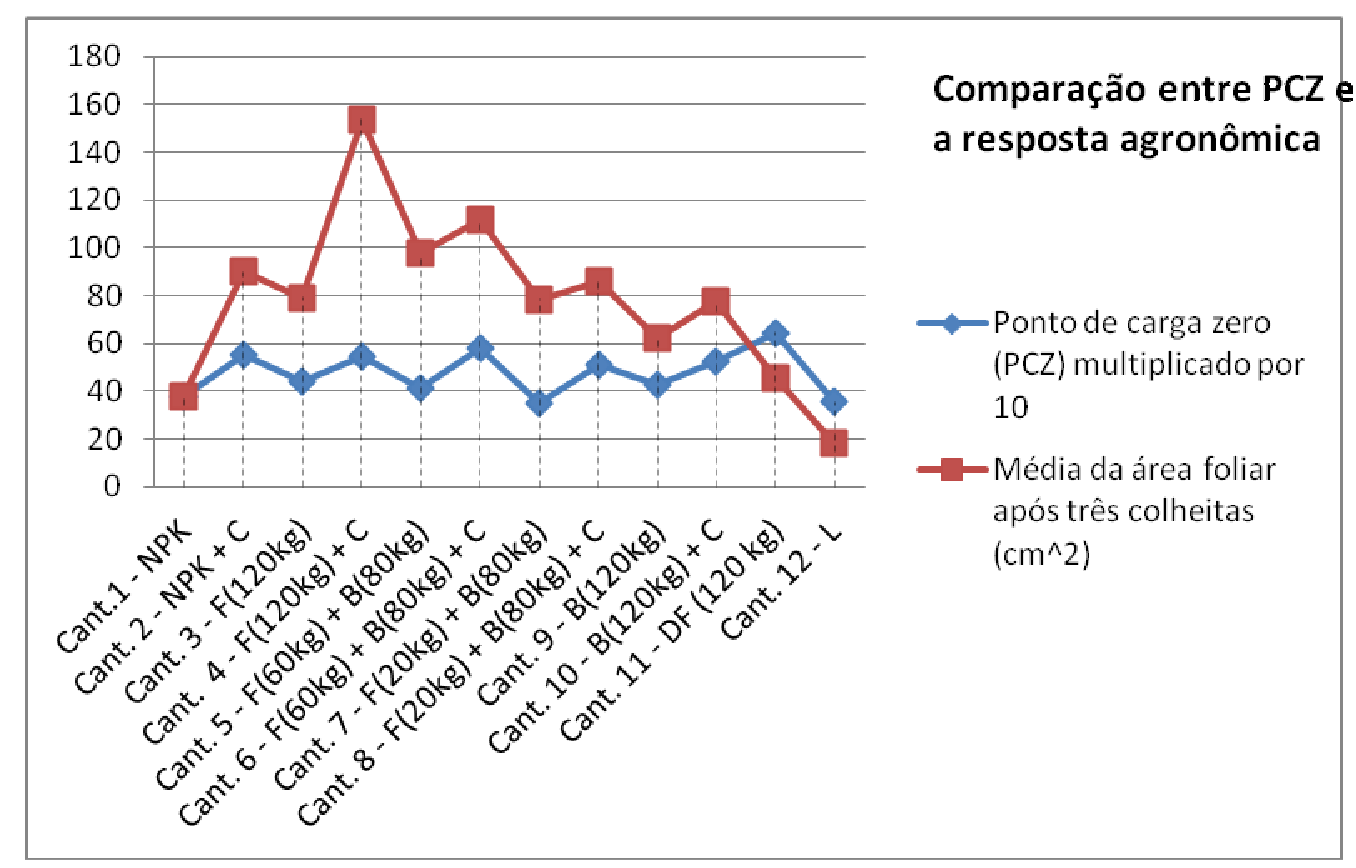

Figura 4.1 - Gráfico com comparação entre os valores de ponto de carga zero (PCZ) e área foliar (AF) ao longo do ano. Notar que os parâmetros apresentam um comportamento muito semelhante, com exceção do canteiro rico em dolomito fosfatado. Isto se deve ao elevado teor de $\mathrm{Ca}$ e $\mathrm{Mg}$ e ao baixo teor nos demais nutrientes. O PCZ teve seus valores multiplicados por dez para uma melhor visualização no gráfico. 


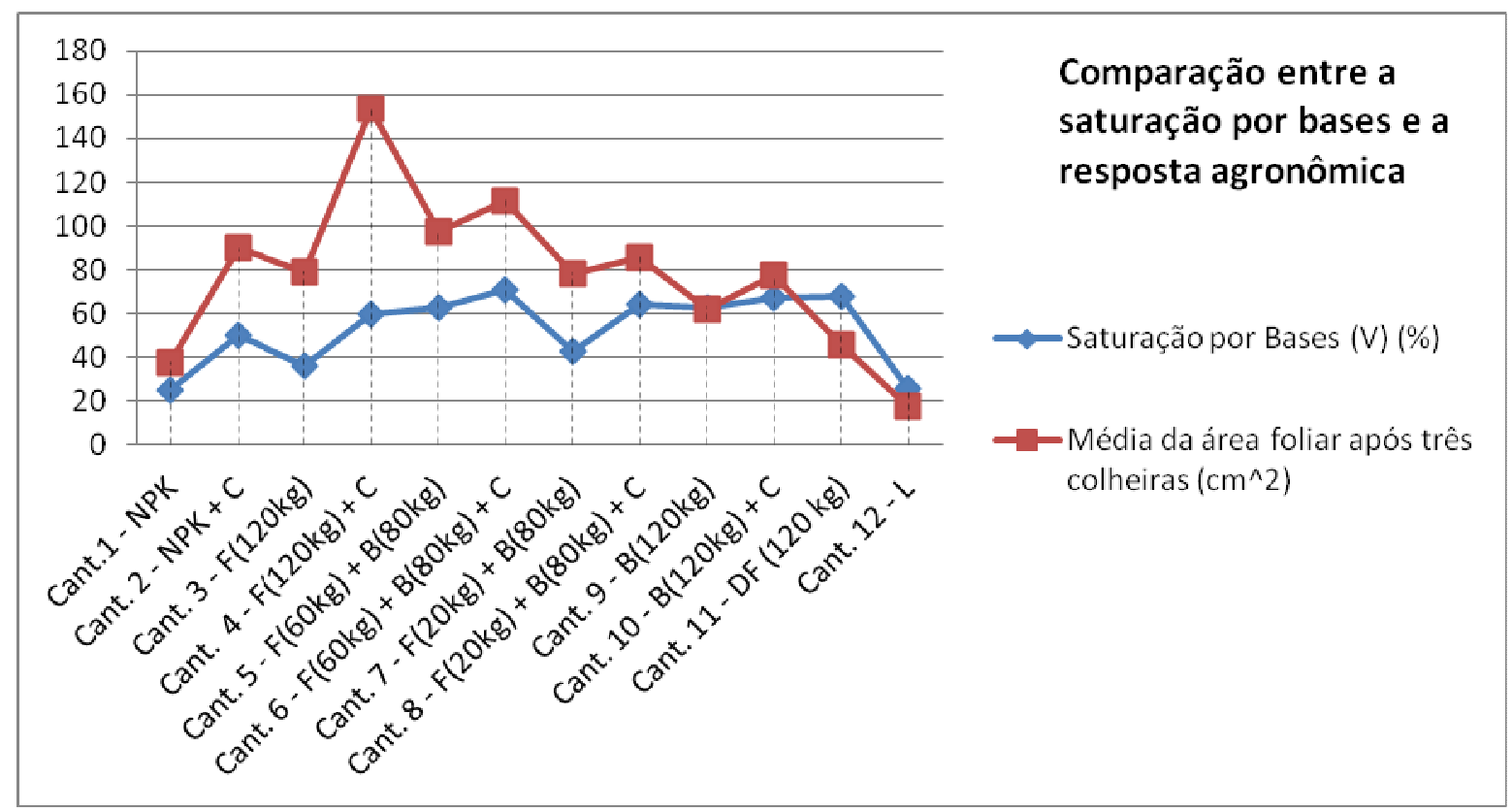

Figura 4. 2 - Gráfico com a comparação entre a saturação por bases e a área foliar. Notar uma correlação significativa, entretanto, seu comportamento é menos semelhante quando comparado ao gráfico da Figura 4.1.

Os dados mineralógicos podem ser sintetizados na Tabela 4.1, onde se observa a adição de minerais do grupo dos fosfatos como a fluorapatita e dos argilominerais como a montmorilonita e a vermiculita. Além destes minerais, verifica-se especialmente nas misturas com basaltos uma mineralogia mais complexa com anortita, augita e albita. A dolomita, mineral importante na regulação do pH é encontrado somente no canteiro rico em dolomito fosfatado e no canteiro oito $(\mathrm{F}(20 \mathrm{~kg})+\mathrm{B}(80 \mathrm{~kg})+\mathrm{C})$, oriundo provavelmente do processo de calagem. Esta mineralogia adicionada pode ser fonte importante de macronutrientes como $\mathrm{P}, \mathrm{Na}, \mathrm{Ca}$ e $\mathrm{Mg}$.

Ainda que não se tenha observado neoformação mineral ao longo do tempo de avaliação dos experimentos, é provável que no decorrer dos anos, alguns minerais presentes especialmente nos basaltos evoluam para argilominerais com estrutura tipo 2:1.

Por fim, quanto aos resultados agronômicos, percebe-se que o uso da calagem é muito importante para o pleno desenvolvimento das plantas. Este fato é de fundamental importância, pois indica que o uso da rochagem por si só, não produziria resultados muito satisfatórios, devido a sua elevada tonelagem e a sua moderada resposta agronômica. Entretanto, quando utilizado em conjunto com calagem apresenta resultados superiores até ao fertilizante solúvel com correção de $\mathrm{pH}$.

Este raciocínio vai de acordo com os trabalhos de Gillman (1980) e Gillman et al. (2002) os quais dizem que o uso de pós de rocha especialmente de origem basáltica não apresentam aumento do pH de forma significativa. Entretanto o presente trabalho vai em direção oposta aos estudos de Ndung'u et al. (2006), Beneduzzi (2011) e Melo et al. (2012) que deixam subentendido que a rochagem tem importante efeito na correção do $\mathrm{pH}$. 
Vale salientar, que neste experimento a preocupação com a quantidade viável de tonelagem por hectare dos pós de rocha ficou em segundo plano devido ao maior enfoque no estudo mineralógico e geoquímico.

É interessante observar que no último plantio, as porções com alguma concentração de basalto apresentaram uma resposta agronômica superior às colheitas anteriores. Isto pode estar correlacionado com uma liberação tardia dos nutrientes presentes nas rochas máficas se comparado com o fosforito e o fertilizante solúvel.

Tabela 4. 1 - Tabela com a mineralogia presente nos canteiros. Observar que a mineralogia é mais complexa nas porções onde foram acrescentados pó de basalto. Onde: $\mathrm{C}=$ Calagem, $\mathrm{F}=$ Fosforito, $\mathrm{B}=$ Basalto, DF = Dolomito Fosfatado, L = Latossolo.

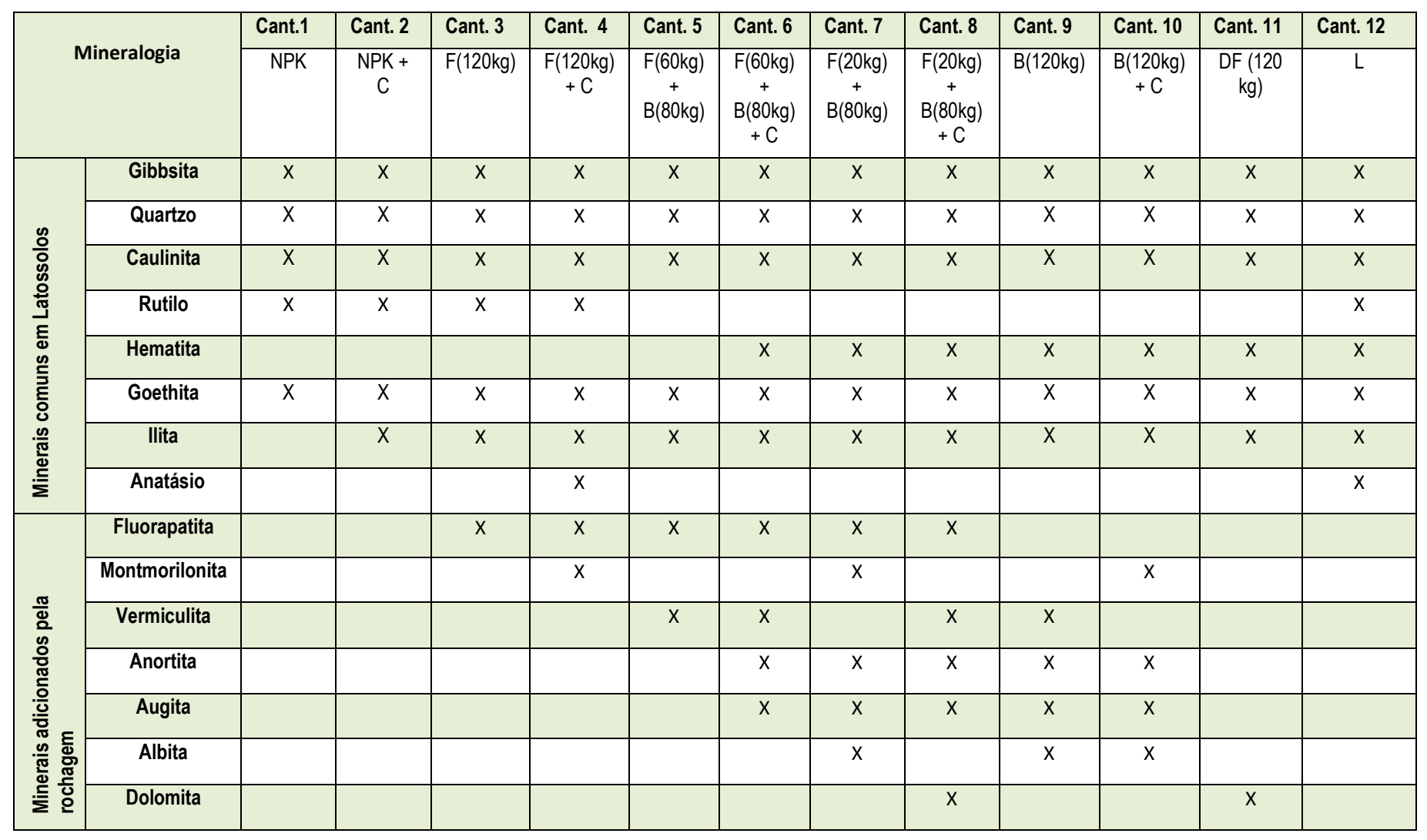

Nota-se que o uso do fosforito é o insumo que apresenta melhores resultados especialmente quando misturado com calagem e/ou basalto. Já as porções de NPK com calagem e basalto com e sem calagem possuem produtividade moderada se comparado com as misturas ricas em fosforito. Por fim, os canteiros de NPK sem calagem, dolomito fosfatado e Latossolo controle nem se quer desenvolveram grãos.

Para trabalhos futuros, recomenda-se a continuação do presente experimento ao menos por cinco anos, para analisar a disponibilidade dos nutrientes e uma possível neoformação mineral. Ainda, recomenda-se que se desenvolvam novas parcelas de plantios com diferentes tonelagens por hectare, para chegar numa equação de viabilidade econômica. 
Outro objeto de estudo futuro interessante seria o aprofundamento nos processos da rizosfera e outros tipos de atividades biológicas, pois podem acelerar a dissolução pela liberação de íons $\mathrm{H}^{+}$e complexação de compostos orgânicos que reagem com a superfície mineral (Harley \& Gilkes 2000). 


\section{REFERÊNCIAS BIBLIOGRÁFICAS}

Abdallah S. Meneghini P.F.V.B. 2013. Carta geológica folha sd.23-v-a Arraias. Escala 1:250.000 CPRM - Programa geologia do brasil. Ministério de minas e energia secretaria de geologia, mineração e transformação mineral.

Albuquerque J.A. Bayer C. Ernani P.R. Fontana E.C. 2000. Propriedades físicas e eletroquímicas de um Latossolo Bruno afetadas pela calagem. R. Bras. Ci. Solo, 24:295-300.

Alfonso Filho R. Azevedo A.C. Ieda J.J.C. 2013. Dissolução de grãos de basalto por ácido sulfúrico. II congresso Brasileiro de Rochagem. Poços de Caldas (MG), p. 27.

Almeida E. Silva F.J.P. Ralisch R. 2007. Revitalização dos solos em processos de transição agroecológica no sul do Brasil. Agriculturas - Rio de Janeiro, 4(1):7-10.

Alvarenga C.J.S. Botelho N.F. Dardenne M.A. Lima O.N.B. Machado M.A. 2006. Nota Explicativa da Folha SD.23-V-C-V (Cavalcante). Escala 1:100.000. Goiás, UnB/CPRM. $76 \mathrm{p}$.

Anda M. Shamshuddin J. Fauziah CI. Omar S.R.S. 2008. Mineralogy and factors controlling charge development of three oxisols developed from different parente materials. Geoderma, 143:153-167.

ANDA. Associação Nacional para Difusão de Adubos. 2016. Anuário estatístico do setor de fertilizantes. São Paulo.

Arnon D.I. \& Stout P.R. 1939. The essentiality of certain elements in minute quantities for plants with special reference to copper. Plant Physiology, 14:371-375.

Appel C. Ma L.Q. Dean Rhue R. Kennelley E. 2003. Point of zero charge determination in soils and minerals via traditional methods and detection of electroacoustic mobility. Geoderma 113: 77-93.

Baligar V.C. Fageria N.K. He Z.L. 2001. Nutrient use efficiency in plants. Communications in Soil Science Plant Analysis, 32(7/8):921-950.

Banfield J.F. \& Hamers R.F. 1997. Processes at mineral surfaces with relevance to microorganisms and prebiotic synthesis. In: Banfield JF \& Nealson KH (eds) Geomicrobiology: Interactions Between Microbes and Minerals, Rev Min. Mineralogical Society of America, Washington, 35:81-122.

Barak P. Chen Y. Singer A. 1983. Ground basalt and tuff as iron fertilizer for calcareous soils. Plant Soil, 73:155-158.

Barnett C. Brown D. Burkit A. Cooper C. Croome C. Fox B. Gould D. Haan D. Hawkes N. Headington C. Kerrod R. Robertson P. Scharf A. Smith T. Taylor G.R. Upton N. Williams E. 1983. História dos Grandes Inventos. Editora Reader's Digest. 151p.

Bellarby J. Foereid B. Hastings A. Smith P. 2008. Cool farming: Climate impacts of agriculture and mitigation potential. Greenpeace International. Amsterdam, 1:1-44.

Beneduzzi E.B. 2011. Rochagem: Agregação das rochas como alternativa sustentável para a fertilização e adubação de solos. Dissertação de mestrado UFGRS. Departamento de Geologia, 86p.

Bergsma H.L.T. Campos dos Santos A.T. Carpay E.A.P.M. 2009. Introducing stone meal in the Netherlands. In: Anais I Congresso Brasileiro de Rochagem. Brasília, p. 55-65.

Berner R.A. Sjoberg E.L. Velbel M.A. Kroh M.D. 1980. Dissolution of pyroxenes and amphiboles during weathering. Science, 207:1205-1206.

Blum W.E.H. Herbinger B. Mentler A. Ottner F. Pollack M. Unger E. Wenzel W.W. 1989. The use of rock powders in agriculture. I. Chemical and mineralogical composition and suitability of rock powders for fertilization. Z Pflanzenernaehr Bodenk 152:421-425.

Bolland M.D.A. Posner A.M. Quirk J.P. 1976. Surface charge on kaolinite in aqueous suspention. Aust. J. Soil Res, 14:197-216.

Bolland M.D.A. \& Baker M.J. 2000. Powdered granite is not an effective fertilizer for clover and wheat in sandy soils from Western Australia. Nutrient Cycling in Agroecosystems, 56:5968.

Braga J.N. 1970. Resultados experimentais com o uso de fosfato de Araxá e outras fontes de fósforo. Viçosa UFV. (UFV. Boletim, 21). Revisão de Literatura, 61p. 
Brandt K. \& Molgaard J.P. 2001. Organic agriculture: does it enhance or reduce the nutritional value of plant foods? Journal of the Science of Food and Agriculture, 81:924-931

Calvert D.V. 1975. Nitrate, phosphate, and potassium movement into drainage lines under three soil management systems. Journal of Environmental Quality 4:183-186.

Casey W.H. \& Bunker B. 1990. Leaching of mineral and glass surfaces during dissolution. In: Hochella MF Jr. \& White AF (eds) Mineral-Water Interface Geochemistry, Ver. Min. Mineralogical Society of America, Washington.

Casey W.H. 2008. Glass and mineral corrosion. Dynamics and durability. nature materials. Califórnia (EUA), 7:390-931.

Castro Filho C. \& Logan T.J. 1991. Liming effects on the stability and erodibility of some Brazilian Oxisols. Soil Sci. Soc. Am. J., 55:1407-1413.

Charlet L. \& Sposito G. 1989. Bivalent ion adsorption by na Oxisol. Soil Sci. Soc. Am. J, 53:691-595.

Chen G.C. He Z.L. Stoffella P.J. Yang X.E. Yu S. Calvert D. 2006. Use of dolomite phosphate rock (DPR) fertilizers to reduce phosphorus leaching from sandy soil. Environmental Pollution, 139(1):176-182.

Chesworth W. 1977. Weathering stages of the common igneous rocks, index minerals and mineral assemblages at the surface of the earth. Jour. Soil ScL 28:490-497.

Chesworth W. 1982. Late Cenozoic geology and the second oldest profession. Geoscience Canada, 9:54-61.

Chesworth W. Magias-Vasquez F. Acquaye D.Thomson E. 1983. Agricultural alchemy: stones into bread. Episodes, 1:3-7.

Chesworth W. Van Straaten P. Semoka J. Mchihiyo E. 1985. Agrogeology in Tanzania. Episodes, 8:257-258.

Chesworth W. Van Straaten, P. Semoka J.M.R. 1989. Agrogeology in East Africa: the Tanzania-Canada project. Journal of African Earth Sciences, 9:357-362.

Chien S.H. 1979. Dissolution of phosphate rock in acid soils as influenced by nitrogen and potassium fertilizers. Soil Ci.127:371-376

Chien S.H. Sale P.W.G Hammond L.L 1990. Comparison of the effectiveness of phosphorus fertilizer products. In: Proc. Symposium on Phosphorus Requirements for Sustainable Agriculture in Asia and Oceania: International Rice Research Institute, Manila, Philippines, p. 143-156.

Chien S.H \& Menon R.G. 1995. Factors affecting the agronomic effectiveness of phosphate rock for direct application. Fert Res, 41:227-234.

Conway G. 1997. The doubly green revolution: Food for all in the 21 st century. Penguin Books, London, UK, p. 31-43

Corkidi L. Rowland D.L. Johnson N.C. Allen E.B. 2002. Nitrogen fertilization alters the functioning of arbuscular mycorrhizas at two semiarid grasslands. Plant and soil, 240(2):299-310.

Coroneos C. Hinsinger P. Gilkes R.J. 1996. Granite powder as a source of potassium for plants: a glasshouse bioassay comparing two pasture species. Fert. Res., 45:143-152.

Dardenne M.A. 1978. Síntese sobre a estratigrafia do Grupo Bambuí no Brasil Central. In: Congresso brasileiro de geologia 30. Recife, 1978. Anais. Recife, S.B.G. 2:597-610.

Dardenne M.A. 1979. Lesminéralisations plomb-zinc du Groupe Bambuí et leur contexte géologique. Paris, Université Pierre et Marie Curie. (Thèse Doc. Université Pierre et Marie Curie). 251p.

Dardenne M.A. 2000. The Brasília Fold Belt. In Cordani U.G., Milani E.J., Thomaz Filho A., Campos D.A.( Edits ), Tectonic Evolution of South America, 31 Int. Geol. Congress, Rio de Janeiro, Brazil 2000, p.231-264.

Darrah P.R. 1993. The rhizosphere and plant nutrition: a quantitative approach. Plant Soil 155/156:1-20

Deer W.A. Howie R.A. Zussman J. (Eds). 1992. Minerais constituintes das rochas - Uma introdução. Lisboa, Fundação Calouste Gulbenkian, 688p. 
EMBRAPA - Empresa Brasileira de Pesquisa Agropecuária. 2006. Disponível em http://www.infoteca.cnptia.embrapa.br. Acessado em 3 jan 2014.

Erhart J. 2009. Efeito do pó de basalto nas propriedades químicas do Solo e nutrição da videira Cabernet sauvignon. Lages SC. Dissertação (Mestrado) - Centro de Ciências Agroveterinárias / UDESC 71p.

Ernani P.R. 1996. The effect of ionic strength on soil $\mathrm{P}$ reactions is negligible. Fertilizer Research, 45:193-197.

Ernani P.R. Figueiredo O.A.R. Becegato V. e Almeida J.A. 1996. Decréscimo da retenção de fósforo no solo pelo aumento do pH. R. Bras. Ci. Solo, 20:159-162.

Ernani P.R. Nascimento J.A.L. Oliveira L.C. 1998. Increase of grain and green matter of corn by liming. R. Bras. Ci. Solo, 22:275-280.

Ernani P.R. Steckling C. Bayer C. 2001. Características químicas de solo e rendimento de massa seca de milho em função do método de aplicação de fosfatos, em dois níveis de acidez. Revista Brasileira de Ciência do Solo, Viçosa, 25:939-946.

Ferrari V.C. 2000. Fosfatos primários e secundários nos perfis de intemperismo sobre os maciços de Juquiá (SP), Anitápolis (SC) e Tapira (MG). Instituto de Geociências, Universidade de São Paulo, Tese de Doutorado, 241p

Flicoteaux R. \& Lucas J. 1984. Weathering of phosphate minerals. In: Nriagu \& Moore eds., Phosphate Minerals, Springer-Verlag, p. 292-317.

Fodor R.V. Corwin C. Roisenburg A. 1985. Petrology of Serra Geral (Paraná) continental flood basalts, southern Brazil crustal contamination, source material, and South Atlantic magmatism. Contrib Mineral Petrol. 91:54-65.

Fyfe W.S. 1981. The environmental crisis: quantifying geosphere interactions. Science 2:105110.

Fyfe W.S. Kronberg B.I. Leonardos O.H. Olorufemi N. 1983. Global tectonics and agriculture: a geochemical perspective. Agr Ecosyst Env 9:383-399.

Gholizadeh A. Ardalan M. Tehrani M.M. Hosseini H.M. Karimian N. 2009. Solubility test in some phosphate rocks and their potential for direct application in soil. World Applied Sciences Journal 6(2):182-190.

Gillman G.P. 1980. The effect of crushed basalt scoria on the cation exchange properties of a highly weathered soil. Soil Sci Soc Am, 44:465-468.

Gillman G.P. Burkett D.C. Coventry R.J. 2002. Amending highly weathered soils with finely ground basalt rock. Applied Geochem, 17:987-1001.

Goedert W.J \& Lobato E. 1980. Avaliação agronômica de fosfatos em solo de cerrado. Pesq. Agropec. bras., Brasília, 18:499-506.

Goepfert C.F.A. 1975. Eficiência de diversos fertilizantes fosfatados na cultura da soja. Rio Grande do Sul. Revisão Bibliográfica, p. 1-38.

Gusev G.M. Zanin Y.U.N. Krivolutskaya L.M. Lemina N.M. Yusupov T.S. 1976. Transformation of apatite during weathering and leaching. Doklady Akad. Nauk SSSR, 229:146-148.

Harley A.D. \& Gilkes R.J. 2000. Factors influencing the release of plant nutrient elements from silicate rock powders: A geochemical overview. Nutr. Cycl. Agroecosyst, 56:1-36.

Hartmann J. \& Kempe S. 2008. What is the maximum potential for CO2 sequestration by "stimulated" weathering on the global scale? Naturwissenschaften, 95:1159-1164.

Hawkes H.E. \& Webb J.S. 1962, Geochemistry in mineral exploration. New York: Harper \& How. 415p.

Heaton S. 2001. Organic farming, food quality and human health - a review of the evidence. Bristol, UK: Soil Association, p. 1-88.

Hensel J. 1890. Das Leben. (in German) Verlag Boericke und Tafel, Leipzig, Germany.

Hensel J. 1894. Bread from stones. TAFEL AJ (Ed), Philadelphia, USA.

Hering J.G. \& Stumm W. 1990. Oxidative and reductive dissolution of minerals. In: Hochella MF and White AF (eds) Mineral Water Interface Geochemistry, Rev Min. Mineralogical Society of America, Washington, v. 23, p. 427-465. 
Hinsinger P. \& Jaillard B. 1993. Root-induced release of interlayer potassium and vermiculitization of phlogopite as related to potassium depletion in the rhizosphere of ryegrass. J Soil Sci v. 44, p. 525-534.

Hinsinger P. Bolland M.D.A. Gilkes R.J. 1996. Silicate rock powder: effect on selected properties of a range of soils from Western Australia and on plant growth as assessed in a glasshouse experiment. Fert. Res., 45:69-79.

Husnain Rochayatia S. Sutriadia T. Nassirb A. Sarwanic M. 2014. Improvement of Soil Fertility and Crop Production through Direct Application of Phosphate rock on Maize in Indonesia. $2^{\text {nd }}$ International Symposium on Innovation and Technology in the Phosphate Industry. 83:336-343.

IBGE - Instituto Brasileiro de Geografia e Estatística. 2007. Manual Técnico de Pedologia, $2^{\mathrm{a}}$ edição. Rio de Janeiro: Ministério do Planejamento, Orçamento e Gestão. Instituto Brasileiro de Geografia e Estatística - IBGE. Diretoria de Geociências. Coordenação de Recursos Naturais e Estudos Ambientais. Manuais Técnicos em Geociências, 4:316.

Jesus Júnior W.C. Vale F.X.R. Coelho R.R. Costa L.C. 2001. Comparison of two methods for estimating leaf area index on common bean. Agronomy Journal, Madison, 93(5):989-991.

Keller W.D. Balgord W.D. Reesman A.L. 1963. Dissolved products of artificially pulverized silicate minerals and rocks. J Sediment Petrol, 33:191-204.

Keng J.C.W. \& Uehara G. 1974. Chemistry, mineralogy and taxonomy of Oxisols and Ultisols. Proceedings of Soil Crop Science Society of Florida, 33:119-126.

Ker J.C. 1995. Mineralogia, sorção e desorção de fosfato, magnetização e elementos traços de Latossolos do Brasil. Dissertação de mestrado. Viçosa, MG, UFV. 181p.

Ker J.C. 1998. Latossolos do Brasil: Uma revisão. Geonomos (UFMG), 5:17-40.

Ketterings Q.M. Albrecht G. Beckman J. 2005. Soil pH for Field Crops. Agronomy Fact Sheet Series. Fact Sheet 5. Cornell University Cooperative Extension, p. 1 a 2.

Kulaif Y. \& Fernandes F.R.C. 2010. Panorama dos agrominerais no Brasil: Atualidade e perspectivas. In: capítulo I - Agrominerais para o Brasil, 1:1-22.

Lapido-Loureiro F.E.V. \& Nascimento M. 2009. Importância e função dos fertilizantes numa agricultura sustentável e competitiva, Rio de Janeiro. In: Lapido-Loureiro F. E. Melamed R. Figueiredo Neto J. (Ed.). Fertilizantes: agroindústria e sustentabilidade. CETEM/Petrobrás, cao. 2, p. 81-132.

Leal J.R. 1971. Adsorção de fosfato em Latossolos sob cerrado. Dissertação de mestrado. Itaguaí, RJ. UFRRJ. P. 1-96.

Léon L.A. Fenster W.E. Hammond L.L. 1986. Agronomic potential of eleven phosphate rocks from Brazil, Colombia, Peru and Venezuela. Soil Sci Soc Am J, 50:798-802.

Leonardos O.H. Fyfe W.S. e Kronberg B.I. 1976. Rochagem: O método de aumento da fertilidade em solos lixiviados e arenosos. In: Anais 29 Congresso Brasileiro de Geologia. Belo Horizonte, p. 137-145.

Leonardos O.H. Fyfe W.S. Kronberg B.I. 1987. The Use of Ground Rocks in Laterite Systems: an Improvement to the Use of Conventional Soluble Fertilizers. Chemical Geology, 60:361370.

Levinson A.A. 1974. Introduction to exploration geochemistry. Aplied Publ. Ltd. Wilmette, Illinois, USA, 614p.

Lima O.N.B. Uhlein A. Britto W. 2007. Estratigrafia do Grupo Bambuí na Serra da Saudade e geologia do depósito fosfático de Cedro do Abaeté, Minas Gerais. Revista Brasileira de Geociências, 37:204-215

Lima S.A.A. 1997. Fácies, ambiente deposicional e aspectos diagenéticos das rochas carbonáticas da Formação Sete Lagoas na região norte de Minas Gerais, Bacia do São Francisco. Dissertação de Mestrado, Departamento de Geologia, Escola de Minas, Universidade Federal de Ouro Preto, $121 \mathrm{p}$.

Lopes O.M.M. Carrilho E.N.V.M. Assad L.R.C. 2014. Effect of rock powder and vinasse on two types of soils. R. Bras. Ci. Solo, 38:1547-1557.

Lucas J. Flicoteaux R. Nathan Y. Prévôt L. Shahat Y. 1980. Different phosphorite weathering. 
SEPM Special Publication 29:41-51.

Luz A.B. Lapido-Loureiro F. E. Sampaio J. A. Castilho Z.C.C. Bezerra. M. S. 2010. Rochas, minerais e rotas tecnológicas para a produção de fertilizantes alternativos. In: capítulo IV Agrominerais para o Brasil, 1:61-83.

Machado A.T.S. Bertagna F.A.B. Santos P. Figueiredo R. Souza Junior I.G. Costas A.C.S. 2013. Cargas superficiais de um Latossolo após aplicação de adubos orgânicos, inorgânicos e resíduos industriais. Anais Eletrônico VIIIIII EPCC - Encontro Internacional de Produção Científica Cesumar UNICESUMAR - Centro Universitário Cesumar Editora CESUMAR Maringá - Paraná - Brasil.

Machado F.B. 2005. Geologia e aspectos petrológicos das rochas intrusivas e efusivas mesozóicas de parte da borda leste da Bacia do Paraná no estado de São Paulo. Universidade Estadual Paulista. Dissertação de Mestrado Rio Claro - SP. p: 1- 95.

Machado F.B. Nardy A.J.R. Rocha JR. E.R.V. Marques L.S. Oliveira M.A.F. 2009. Geologia e litogeoquímica da Formação Serra Geral nos estados de Mato grosso e Mato Grosso do Sul. Revista Geociências, Universidade Estadual Paulista (UNESP), São Paulo, 28(4):523-400.

Magalhães A.F. \& Page A.L. 1984. Características das cargas elétricas dos solos da zona da Mata de Pernambuco. Determinação das cargas de superfície. R. Bras. Ci. Solo, 8:173-177.

Malavolta E. 1980. Elementos de nutrição mineral de plantas. Editora Agronômica Ceres, São Paulo, $251 \mathrm{p}$.

Malavolta E. 1999. Mineral nutrition of higher plants - the first 150 years. In: Siqueira J. O. Moreira F. M. S. Lopes A. S. Guilherme L. R. G. Faquim, V. Furtini A. E. Carvalho J. G. (Ed.). Inter-relação fertilidade, biologia do solo e nutrição de plantas. Viçosa: Lavras, p. 51122.

Malavolta E. 2008. O Futuro da nutrição de plantas tendo em vista aspectos agronômicos, econômicos e ambientais. Informações Agronômicas. International Plant Nutrition Institute. São Paulo, n. 121:1-10.

Malý S. Královec J. Hampel D. 2009. Effects of long-term mineral fertilization on microbial biomass, microbial activity, and the presence of r- and K-strategists in soil. Biol Fertil Soils, v. 45 , p.753-760.

Martins E.S. Oliveira C.G. Resende A.V. Matos M.S.F. 2008. Agrominerais - Rochas Silicáticas como Fontes Minerais Alternativas de Potássio para a Agricultura. In: capítulo IX - Rochas e Minerais Industriais - CETEM, 2:206-223.

Martins E.S. Theodoro S.H. 2009. Apresentação do Congresso Brasileiro de Rochagem. In: Anais do I Congresso Brasileiro Rochagem, 1:3-4.

Martins E.S. Resende A.V. Oliveira C.G. Furtini Neto A.E. 2010. Materiais silicáticos como fontes regionais de nutrientes e condicionadores de solos. In: capítulo V - Agrominerais para o Brasil. RJ. CETEM/MCT. p. 89-99.

Martins E.S. 2013. Proposta de critérios de normatização de rochas silicáticas como fontes de nutrientes e condicionadores de solo. II congresso Brasileiro de Rochagem. Poços de Caldas (MG), p. 50.

Martins V.A. Camargo Filho W.P. Bueno C.R.F. 2006. Preços de frutas e hortaliças da agricultura orgânica no mercado varejista da cidade de São Paulo. Informações Econômicas, v. 36, p. $42-50$.

McCarty G.W. \& Meisinger J.J. 1997. Effects of N fertilizer treatments on biologically active N pools in soils under plow and no tillage. Biol Fertil Soils, 24:406-421.

McClellan G.H. 1980. Mineralogy of carbonate fiuorapatites. J. Geol. Soc., London, 137:675681.

Medeiros F.P. 2013. Rochagem: Um novo paradigma na agricultura. In: II Congresso Brasileiro de Rochagem. Poços de Caldas MG. p. 75.

Mekaru T. \& Uehara G. 1972. Anion adsorption in ferruginous tropical soils. Soil Sci. Soc. Am. Proc, v. 36:296-300.

Melo V.F. Uchôa S.C.P. Dias F.O. Barbosa G.F. 2012. Doses de basalto moído nas propriedades químicas de um Latossolo Amarelo distrófico da savana de Roraima, 42(4):471-476. 
Milani E.J Melo J.H.G. Souza P.A. Fernandes L.A. França A.B. 2007. Bacia do Paraná. In: Milani E.J. Rangel H.D. Bueno G.V. Stica J.M. Winter W.R. Caixeta J.M. Pessoa Neto O.C (Eds.). Bacias Sedimentares Brasileiras - Cartas Estratigráficas. Boletim de Geociências da Petrobras, Rio de Janeiro, 5(2):265-287.

Missoux M. 1853/54. Sur l'emploi de la poudre des roches granitiques comme excitant de la vegetation. Compt Rend Acad Sci (Paris) t 36: p. 1136; t 37: p. 245.

Monteiro C.F. 2009. Fosforitos do grupo Bambuí na região de Campos Belos (GO) / Arraias (TO), na borda oeste do cráton São Francisco. Universidade de Brasília. Dissertação (Mestrado em Prospecção e Geologia Econômica). 135 p.

Nardy A.J.R. Oliveira M.A.F. Betancourt R.H.S. Verdugo D.R.H. Machado F.B. 2002. Geologia e estratigrafia da Formação Serra geral. Geociências, v. 21, n. 1-2, p. 13-30.

Nascimento Filho V.F. 1999. Técnicas analíticas nucleares de fluorescência de raios X por dispersão de energia (ED-XRF) e por reflexão total (TXRF). Depto de Ciências Exatas/ESALQ Lab. de Instrumentação Nuclear/CENA, p. 1 a 19.

Ndung'u K.W. Okalebo J.R. Othieno C.O. Kifuko M.N. Kipkoech A.K. Kimenye L.N. 2006. Residual effectiveness of minjingu phosphate rock and fallow biomass on crop yields and financial returns in western Kenya. Cambridge, Expl. Agric., v. 42, p. 323-336.

Niwas J.M. Dissanayake C.B. Keerthishinghe G. 1987. Rocks as fertilizers: Preliminary studies on potassium availability of some common rocks in Sri Lanka. App. Geochem, v. 2, p. 243246.

Nobre-Lopes J. 1995. Faciologia e gênese dos carbonatos do Grupo Bambuí na região de Arcos, Estado de Minas Gerais. 1995. Dissertação (Mestrado) - Instituto de Geociências, Universidade de São Paulo, 166 p.

Novais. R.F. Neves J.C.L. Barros N.F. 1991. Aspectos físico-químicos envolvidos na fixação de fósforo no solo. In: Encontro nacional de rocha fosfática, 5, São Paulo. Anais..., São Paulo. p. 133-177.

Oades J.M. Gillman G.P. \& Uehara G. 1989. Interactions of soil organic matter and variablecharge clays. In: Coleman D.C. Oades J.M. Uehara, G. Dynamics of soil organic matter in tropical ecosystems. Honolulu, University of Hawaii, p.69-95.

Oliveira I.P. Santos A.B. Costa K.A.P. 2004. Produção de Sementes Sadias de Feijão Comum em Várzeas Tropicais. Embrapa Arroz e Feijão Sistemas de Produção. Versão eletrônica. N.4 ISSN 1679-8869.

Osaki F. 1991. Calagem e adubação. 2. ed. Instituto Brasileiro de Ensino Agrícola. Campinas, $503 \mathrm{p}$.

Pflug R. \& Renger F. 1973. Estratigrafia e evolução geológica da margem sudeste do Craton Sanfranciscano. In. XXVII Congr. Bras. Geol., Aracaju, v. 2, p. 5-19.

Piccirillo E.M. Raposo M.I.B. Melfi A.J. Comin-Chiaramonti P. Bellieni G. Cordani U.G. Kawashita K. 1987. Bimodal fissural volcanic suítes from the Paraná Basin (Brazil): K-Ar age, Sr-isotopes and geochemistry. Geochimica Brasiliensis, 1:53-69.

Piccirillo E.M. \& Melfi A.J. 1988.The Mesozoic Flood Volcanism of the Paraná Basin: Petrogenetic and Geophysical Aspects. São Paulo, Brasil: IAG-USP. 600 p.

Pomerol C. Lagbrielle Y. Renard M. Guillot. 2013. Princípios de geologia. Técnicas, modelos e teorias. Editora bookman. Cap 27:654-671.

Potts P.J. 1992. A Handbook of Silicate Rock Analysis. 2 ed. London, Glasgow. 70p.

Quintela E.D. \& Ferreira E. 2003. Cultivo do Feijoeiro Comum. Embrapa Arroz e Feijão Sistemas de Produção, 2. Versão eletrônica. ISSN 1679-8869

Raij B. Van \& Peech M.1972. Electrochemical properties of some Oxisols and Alfisols of the tropics. Proc. Soil Sci. Soc. Am. N. 36, p.587-593.

Rosolem C.A. Marubayashi O.M. 1994. Seja o doutor de seu feijoeiro. POTAFOS. Arq. Agrônomo, 7, 4p.

Ribeiro B.T. Lima J.M. Curi N. Oliveira G.C. Lima P.L.T. 2011. Cargas superficiais da fração argila de solos influenciadas pela vinhaça e fósforo. Química Nova, 34:5-10.

Rodrigues A.F.S. 2009. Agronegócio e Mineralnegócio: Relações de dependência e 
sustentabilidade. In: Informe Mineral: Desenvolvimento e Economia Mineral. Brasília: DNPM, 7:28-47.

Rolim M.V. Novais R.F. Nunes F.N. Alvares V.V.H. 2008. Efeito da moagem do solo no teor de fósforo disponível por Mehlich-1, resina em esferas e em lâminas. R. Bras. Ci. Solo, 32:1181-1190.

Ronquim C.C. 2010. Conceitos de fertilidade do solo e manejo adequado para as regiões tropicais. Boletim de Pesquisa e Desenvolvimento. Embrapa Monitoramento por Satélite, Campinas: $26 \mathrm{p}$.

Roth C.H. \& Pavan M.A. 1991. Effect of lime and gypsum on clay dispersion and infiltration in samples of a Brazilian Oxisol. Geoderma, 48:351-361.

Sandim A.S. Büll L.T. Furim A.R. Lima G.S. Garcia J.L.N. 2014. Phosphorus availability in oxidic soils treated with lime and silicate applications. R. Bras. Ci. Solo, 38:1215-1222.

Santos C.C. 2014. Mobilidade de elementos químicos no perfil de solo e seu controle na prospecção geoquímica: aplicação na região de Santa Maria da Vitória, BA. Dissertação de mestrado Brasília DF. UnB.

Sarmento C.C.T. 2013. Geologia e petrologia das rochas hipabissais associadas à Formação Serra Geral na região de Cerro Coronel, Rs. Porto Alegre. Dissertação de Mestrado UFGRS.

Schnitzer M. 1986. Binding of humic substances by soil mineral colloids. In: Huang, P.M. \& Schnitzer, M., eds. Interactions of soil minerals with natural organics and microbes. Madison, Soil Science Society of American, 1:77-101.

Shiki S. Silva J.G. Ortega A.C. 1997. Agricultura, meio ambiente e sustentabilidade do Cerrado Brasileiro. Uberlândia: Universidade Federal de Uberlândia.

Silva A. 2007. Efeito do pó de basalto nas propriedades químicas do solo, nutrição e produtividade do feijoeiro e na nutrição de Eucalyptus benthamii. (Dissertação de mestrado) - Curso de Pós-Graduação em Ciência do Solo, Universidade Estadual do Estado de Santa Catarina - UDESC, Lages, 69p.

Smyth T.J. \& Sanchez P.A.1982. Phosphate rock dissolution and availability in Cerrado soils as affected by phosphorus sorption capacity. Soil Sci. Soc. Am, J. 46:339-345.

Sousa D.M.G. \& Lobato E. 2004. Cerrado: correção do solo e adubação. 2.ed. Planaltina, Embrapa Cerrado, p.129-144.

Sposito, G. 1989. The Chemistry of Soils. New York, Oxford University Press, p. 277.

Souza F.N.S. Alves J.M. Nascente L. M. 2014. Viabilidade do uso de pó de rocha como fonte alternativa de nutrientes no estado do Tocantins. In: II congresso Brasileiro de Rochagem. Poços de Caldas (MG), p. 15.

Souza F.N.S. 2014. O potencial de agrominerais silicáticas como fonte de nutrientes na agricultura tropical. Tese de doutroado $\mathrm{N}^{0} 119$. Universidade de Brasília, p. 1-107.

Sverdrup H. \& Warfvinge P. 1995. Estimating field weathering rates using laboratory kinetics. In: White AF \& Brantley SL (eds) Chemical Weathering Rates of Silicate Minerals, Rev Min., Mineralogical Society of America, Washington., v. 31, p. 485-541.

Tavares Filho J . Barbosa G.M.C. Ribon A.A. 2010. Water-dispersible clay in soil treated with sewage sludge. Revista Brasileira de Ciência do Solo, v. 34, n.5, p. 1527-1534.

Teixeira W. Toledo M.C.M. Fairchild T.R. Taioli F. 2001. Decifrando a Terra. Editora: Oficina de Textos. Usp. Cap 8:139-157.

Thiede D.S. Vasconcelos P.M. 2010. Paraná flood basalts: rapid extrusion hypothesis confirmed by new 40Ar/39Ar results. Geology, 38(8):747-750.

Tisdale S.L. Nelson W.L. Beaton J.D. 1990. Soil fertility and fertilizers. Macmillan Publishing Co. Inc. Nova York, Ed. 4, p. 1-754.

Toebe M. Cargnelutti Filho A.. Loose L.H. Heldwein A.B. Zanon A.J. 2012. Área foliar de feijão-vagem (Phaseolus vulgaris L.) em função de dimensões foliares. Semana: Ciências Agrárias, 33:2491-2500.

Toledo M.A.A. 1998. Determinação de Elementos-Traço Em Silicatos Por Espectrometria de Fluorescência de Raios X: Estudo e Avaliação de Metodologia; Dissertação (Mestrado em Geociências) - Universidade Estadual de Campinas, Conselho Nacional de Desenvolvimento 
Científico e Tecnológico; Orientador: Jacinta Enzweiler; p 5 a 6.

Troxler S. 1999. Clay Minerals: Their Importance and Function in Soils. Soil Fertility, 13:1-2.

Van Straaten P. 2006. Farming with rocks and minerals: challenges and opportunities. Anais da Academia Brasileira de Ciências, 73(4):731-747.

Volkweiss S.J. \& Raij B. Van. 1977. Retenção e disponibilidade de fósforo em solos. In: simpósio sobre o cerrado, 4. Belo Horizonte. Anais... Belo Horizonte: Itatiaia, p. 317-332.

Waigwa M.W. Othieno C.O. Okalebo J.R. 2003. Phosphorus availability as affected by the application of phosphate rock combined with organic materials to acid soils in western Kenya. Cambridge University in the United Kingdom. Expl Agric. 39:395-407.

White A.F. \& Blum A.E. 1994. Effects of climate on chemical weathering in watersheds. Goldschmidt conference Edinburgh. Mineralogical Magazine, 58:967-968.

Wollast R. \& Chou L. 1985. Kinetics study of the dissolution of albite with a continuous flowthrough fluidized bed reactor. In: Drever JI (ed) The Chemistry of Weathering. Reidel: Dordrecht, The Netherlands., p. 75-96.

Yanai J. Robinson D. Young I.M. Kyuma K. Kosaki T. 1998. Effects of the chemical form of inorganic nitrogen fertilizers on the dynamics of the soil solution composition and on nutrient uptake by wheat. Plant and Soil, 2:263-270. 


\section{ANEXOS}

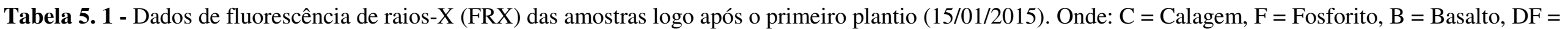
Dolomito Fosfatado, L = Latossolo.

\begin{tabular}{|c|c|c|c|c|c|c|c|c|c|c|c|c|c|c|c|c|c|}
\hline & RT - 01 & RT - 02 & RT - 03 & RT - 04 & RT - 05 & T - 06 & RT - 07 & T - 08 & RT - 09 & RT - 10 & 11 & RT - 12 & T - L1 & RT - B & RT - F & RT - CF & RT - NPK \\
\hline & NPK & $\mathrm{NPK}+\mathrm{C}$ & $\mathrm{F}(120 \mathrm{~kg})$ & $\begin{array}{c}\mathrm{F}(120 \mathrm{~kg})+ \\
\mathrm{C}\end{array}$ & $\begin{array}{c}\mathrm{F}(60 \mathrm{~kg})+ \\
\mathrm{B}(80 \mathrm{~kg})\end{array}$ & $\begin{array}{c}\mathrm{F}(60 \mathrm{~kg})+ \\
\mathrm{B}(80 \mathrm{~kg}) \\
+\mathrm{C}\end{array}$ & $\begin{array}{l}\mathrm{F}(20 \mathrm{~kg})+ \\
\mathrm{B}(80 \mathrm{~kg})\end{array}$ & $\begin{array}{c}\mathrm{F}(20 \mathrm{~kg})+ \\
\mathrm{B}(80 \mathrm{~kg})+ \\
\mathrm{C}\end{array}$ & $\mathrm{B}(120 \mathrm{~kg})$ & $\begin{array}{l}B(120 \mathrm{~kg}) \\
+\mathrm{C}\end{array}$ & $\begin{array}{c}\mathrm{DF}(120 \\
\mathrm{kg})\end{array}$ & L & \multicolumn{5}{|c|}{$\begin{array}{l}\text { Análises dos insumos antes de serem aplicados no } \\
\text { experimento. }\end{array}$} \\
\hline $\mathrm{SiO}_{2}$ & $18,618 \%$ & $18,844 \%$ & $24,191 \%$ & $31,991 \%$ & $25,466 \%$ & $22,095 \%$ & $29,313 \%$ & $22,387 \%$ & $24,818 \%$ & $24,929 \%$ & $17,308 \%$ & $19,652 \%$ & $19,895 \%$ & $42,772 \%$ & $56,016 \%$ & $9,108 \%$ & $1,701 \%$ \\
\hline $\mathrm{Al}_{2} \mathrm{O}_{3}$ & $50,836 \%$ & $48,984 \%$ & $41,263 \%$ & $37,618 \%$ & $37,625 \%$ & $43,552 \%$ & $32,983 \%$ & $45,127 \%$ & $40,836 \%$ & $40,998 \%$ & $39,641 \%$ & $49,822 \%$ & $49,058 \%$ & $11,586 \%$ & $13,865 \%$ & $2,025 \%$ & $0,724 \%$ \\
\hline $\mathrm{MgO}$ & $0,071 \%$ & $0,357 \%$ & $0,405 \%$ & $0,694 \%$ & $0,994 \%$ & $0,607 \%$ & $1,297 \%$ & $0,582 \%$ & $0,868 \%$ & $1,025 \%$ & $3,825 \%$ & $0,157 \%$ & $0,129 \%$ & $4,489 \%$ & $0,957 \%$ & $20,836 \%$ & $0,824 \%$ \\
\hline $\mathrm{Fe}_{2} \mathrm{O}_{3}$ & $25,574 \%$ & $25,812 \%$ & $20,076 \%$ & $20,761 \%$ & $20,387 \%$ & $23,282 \%$ & $20,304 \%$ & $23,109 \%$ & $24,229 \%$ & $23,323 \%$ & $21,550 \%$ & $25,097 \%$ & $25,801 \%$ & $23,153 \%$ & $825 \%$ & $3,516 \%$ & $3,766 \%$ \\
\hline $\mathrm{CaO}$ & $0,065 \%$ & $1,017 \%$ & $5,985 \%$ & $2,441 \%$ & $7,125 \%$ & $4,108 \%$ & $7,786 \%$ & $2,837 \%$ & $3,410 \%$ & $3,846 \%$ & $12,803 \%$ & $0,116 \%$ & $0,077 \%$ & $9,906 \%$ & $9,723 \%$ & $61,036 \%$ & $24,518 \%$ \\
\hline $\mathrm{Na}_{2} \mathrm{O}$ & $0,010 \%$ & $0,011 \%$ & $0,015 \%$ & $0,017 \%$ & $0,178 \%$ & $0,134 \%$ & $0,483 \%$ & $0,106 \%$ & $0,357 \%$ & $0,361 \%$ & $0,015 \%$ & $0,013 \%$ & $0,017 \%$ & $1,985 \%$ & $0,029 \%$ & $0,009 \%$ & $0,812 \%$ \\
\hline $\mathrm{K}_{2} \mathrm{O}$ & $0,499 \%$ & $0,570 \%$ & $0,964 \%$ & $1,103 \%$ & $1,088 \%$ & $0,896 \%$ & $1,079 \%$ & $0,923 \%$ & $0,961 \%$ & $0,993 \%$ & $0,861 \%$ & $0,870 \%$ & $0,814 \%$ & $1,159 \%$ & $2,045 \%$ & $0,597 \%$ & $15,145 \%$ \\
\hline $\mathrm{TiO}_{2}$ & $3,768 \%$ & $3,826 \%$ & $3,109 \%$ & $2,900 \%$ & $3,141 \%$ & $3,510 \%$ & $3,508 \%$ & $3,545 \%$ & $3,848 \%$ & $3,834 \%$ & $3,115 \%$ & $3,684 \%$ & $649 \%$ & $3,981 \%$ & $0,744 \%$ & $0,151 \%$ & $0,737 \%$ \\
\hline $\mathrm{P}_{2} \mathrm{O}_{5}$ & $0,153 \%$ & $0,153 \%$ & $3,595 \%$ & $2,084 \%$ & $3,575 \%$ & $1,402 \%$ & $2,726 \%$ & $0,962 \%$ & $0,197 \%$ & $0,197 \%$ & $0,544 \%$ & $0,164 \%$ & $0,149 \%$ & $0,379 \%$ & $7,371 \%$ & $2,454 \%$ & $29,688 \%$ \\
\hline $\mathrm{MnO}$ & $0,046 \%$ & $0,066 \%$ & $0,106 \%$ & $0,097 \%$ & $0,129 \%$ & $0,092 \%$ & $0,210 \%$ & $0,095 \%$ & $0,131 \%$ & $0,150 \%$ & $0,045 \%$ & $0,063 \%$ & $0,053 \%$ & $267 \%$ & $0,272 \%$ & $0,069 \%$ & $0,305 \%$ \\
\hline $\mathrm{SO}_{3}$ & $0,093 \%$ & $0,088 \%$ & $0,072 \%$ & $0,069 \%$ & $0,071 \%$ & $0,070 \%$ & $0,062 \%$ & $0,075 \%$ & $0,070 \%$ & $0,071 \%$ & $0,074 \%$ & $0,086 \%$ & $0,097 \%$ & $0,044 \%$ & $0,015 \%$ & $0,121 \%$ & $20,403 \%$ \\
\hline $\mathrm{Sr}$ & $0,003 \%$ & $0,004 \%$ & $0,008 \%$ & $0,011 \%$ & $0,027 \%$ & $0,026 \%$ & $0,052 \%$ & $0,024 \%$ & $0,045 \%$ & $0,047 \%$ & $0,011 \%$ & $0,003 \%$ & $0,003 \%$ & $0,093 \%$ & $0,024 \%$ & $0,038 \%$ & $0,469 \%$ \\
\hline $\mathrm{Rb}$ & $0,004 \%$ & $0,005 \%$ & $0,007 \%$ & $0,008 \%$ & $0,006 \%$ & $0,007 \%$ & $0,006 \%$ & $0,007 \%$ & $0,006 \%$ & $0,006 \%$ & $0,008 \%$ & $0,008 \%$ & $0,007 \%$ & $0,004 \%$ & $0,009 \%$ & $0,003 \%$ & $0,003 \%$ \\
\hline $\mathrm{Ni}$ & $0,009 \%$ & $0,009 \%$ & $0,009 \%$ & $0,009 \%$ & $0,010 \%$ & $0,010 \%$ & $0,011 \%$ & $0,009 \%$ & $0,010 \%$ & $0,010 \%$ & $0,007 \%$ & $0,008 \%$ & $0,008 \%$ & $0,016 \%$ & $0,013 \%$ & $0,005 \%$ & $0,011 \%$ \\
\hline $\mathrm{Cu}$ & $0,007 \%$ & $0,007 \%$ & $0,007 \%$ & $0,007 \%$ & $0,012 \%$ & $0,012 \%$ & $0,020 \%$ & $0,012 \%$ & $0,019 \%$ & $0,019 \%$ & $0,006 \%$ & $0,007 \%$ & $0,007 \%$ & $0,035 \%$ & $0,007 \%$ & $0,005 \%$ & $0,014 \%$ \\
\hline $\mathrm{Zn}$ & $0,007 \%$ & $0,007 \%$ & $0,009 \%$ & $0,008 \%$ & $0,011 \%$ & $0,010 \%$ & $0,014 \%$ & $0,009 \%$ & $0,012 \%$ & $0,013 \%$ & $0,005 \%$ & $0,007 \%$ & $0,007 \%$ & $0,020 \%$ & $0,016 \%$ & $0,005 \%$ & $0,670 \%$ \\
\hline $\mathrm{Zr}$ & $0,161 \%$ & $0,167 \%$ & $0,117 \%$ & $0,119 \%$ & $0,096 \%$ & $0,119 \%$ & $0,082 \%$ & $0,126 \%$ & $0,113 \%$ & $0,111 \%$ & $0,124 \%$ & $0,166 \%$ & $0,160 \%$ & $0,051 \%$ & $0,030 \%$ & $0,010 \%$ & $0,117 \%$ \\
\hline $\mathrm{Cr}$ & $0,024 \%$ & $0,022 \%$ & $0,020 \%$ & $0,018 \%$ & $0,017 \%$ & $0,020 \%$ & $0,016 \%$ & $0,020 \%$ & $0,019 \%$ & $0,019 \%$ & $0,020 \%$ & $0,025 \%$ & $0,022 \%$ & $0,009 \%$ & $0,009 \%$ & $0,009 \%$ & $0,004 \%$ \\
\hline V & $0,023 \%$ & $0,023 \%$ & $0,020 \%$ & $0,020 \%$ & $0,023 \%$ & $0,025 \%$ & $0,019 \%$ & $0,024 \%$ & $0,029 \%$ & $0,029 \%$ & $0,017 \%$ & $0,023 \%$ & $0,018 \%$ & $0,038 \%$ & $0,009 \%$ & $0,002 \%$ & $0,006 \%$ \\
\hline Co & $0,001 \%$ & $0,001 \%$ & $0,001 \%$ & $0,002 \%$ & $0,002 \%$ & $0,002 \%$ & $0,004 \%$ & $0,003 \%$ & $0,003 \%$ & $0,004 \%$ & $0,001 \%$ & $0,001 \%$ & $0,001 \%$ & $0,008 \%$ & $0,004 \%$ & $0,000 \%$ & $0,008 \%$ \\
\hline $\mathrm{Nb}$ & $0,010 \%$ & $0,011 \%$ & $0,008 \%$ & $0,007 \%$ & $0,006 \%$ & $0,007 \%$ & $0,005 \%$ & $0,008 \%$ & $0,007 \%$ & $0,007 \%$ & $0,008 \%$ & $0,010 \%$ & $0,010 \%$ & $0,003 \%$ & $0,001 \%$ & $0,000 \%$ & $0,059 \%$ \\
\hline $\mathrm{Pb}$ & $0,016 \%$ & $0,016 \%$ & $0,015 \%$ & $0,016 \%$ & $0,001 \%$ & $0,012 \%$ & $0,008 \%$ & $0,012 \%$ & $0,009 \%$ & $0,006 \%$ & $0,012 \%$ & $0,016 \%$ & $0,009 \%$ & $0,001 \%$ & $0,018 \%$ & $0,002 \%$ & $0,015 \%$ \\
\hline Total & $99,998 \%$ & $100,000 \%$ & $100,002 \%$ & $100,000 \%$ & $99,990 \%$ & $99,998 \%$ & $99,988 \%$ & $100,002 \%$ & $99,997 \%$ & $99,998 \%$ & $100,000 \%$ & $99,998 \%$ & $99,991 \%$ & $99,999 \%$ & $100,002 \%$ & $100,001 \%$ & $99,999 \%$ \\
\hline P.F. & $26,630 \%$ & $27,410 \%$ & $21,750 \%$ & $21,980 \%$ & $11,800 \%$ & $20,580 \%$ & $12,830 \%$ & $21,210 \%$ & $17,940 \%$ & $17,370 \%$ & $30,070 \%$ & $30,110 \%$ & $27,560 \%$ & $17,210 \%$ & $17,360 \%$ & & \\
\hline
\end{tabular}




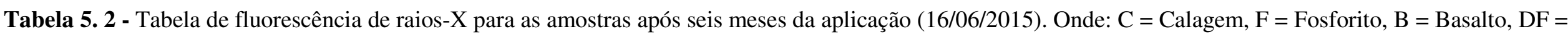
Dolomito Fosfatado, L = Latossolo.

\begin{tabular}{|c|c|c|c|c|c|c|c|c|c|c|c|c|}
\hline & RT - 01 & RT - 02 & RT - 03 & RT - 04 & RT - 05 & RT - 06 & RT - 07 & RT - 08 & RT - 09 & RT - 10 & $\mathrm{RT}$ - 11 & RT - 12 \\
\hline & NPK & $\mathrm{NPK}+\mathrm{C}$ & $\mathrm{F}(120 \mathrm{~kg})$ & $\begin{array}{c}F(120 \mathrm{~kg})+ \\
\mathrm{C}\end{array}$ & $\begin{array}{c}\mathrm{F}(60 \mathrm{~kg})+ \\
\mathrm{B}(80 \mathrm{~kg})\end{array}$ & $\begin{array}{c}F(60 \mathrm{~kg})+ \\
B(80 \mathrm{~kg})+C\end{array}$ & $\begin{array}{c}\mathrm{F}(20 \mathrm{~kg})+ \\
\mathrm{B}(80 \mathrm{~kg})\end{array}$ & $\begin{array}{c}\mathrm{F}(20 \mathrm{~kg})+ \\
\mathrm{B}(80 \mathrm{~kg})+ \\
\mathrm{C}\end{array}$ & $\mathrm{B}(120 \mathrm{~kg})$ & $\begin{array}{c}\mathrm{B}(120 \mathrm{~kg})+ \\
\mathrm{C}\end{array}$ & $\begin{array}{c}\text { DF (120 } \\
\mathrm{kg})\end{array}$ & $\mathrm{L}$ \\
\hline $\mathrm{SiO}_{2}$ & $19,297 \%$ & $19,475 \%$ & $23,347 \%$ & $27,703 \%$ & $20,106 \%$ & $21,863 \%$ & $21,524 \%$ & $23,825 \%$ & $21,241 \%$ & $20,743 \%$ & $19,394 \%$ & $19,616 \%$ \\
\hline $\mathrm{Al}_{2} \mathrm{O}_{3}$ & $50,114 \%$ & $49,831 \%$ & $45,090 \%$ & $42,012 \%$ & $48,208 \%$ & $46,288 \%$ & $48,453 \%$ & $43,797 \%$ & $47,321 \%$ & $48,090 \%$ & $46,870 \%$ & $49,730 \%$ \\
\hline $\mathrm{MgO}$ & $0,088 \%$ & $0,177 \%$ & $0,294 \%$ & $0,365 \%$ & $0,191 \%$ & $0,399 \%$ & $0,270 \%$ & $0,766 \%$ & $0,378 \%$ & $0,399 \%$ & $0,969 \%$ & $0,149 \%$ \\
\hline $\mathrm{Fe}_{2} \mathrm{O}_{3}$ & $25,508 \%$ & $25,439 \%$ & $22,928 \%$ & $22,494 \%$ & $25,491 \%$ & $24,061 \%$ & $23,845 \%$ & $24,019 \%$ & $25,136 \%$ & $24,828 \%$ & $25,123 \%$ & $25,215 \%$ \\
\hline $\mathrm{CaO}$ & $0,153 \%$ & $0,234 \%$ & $2,049 \%$ & $1,558 \%$ & $0,446 \%$ & $1,646 \%$ & $0,631 \%$ & $2,122 \%$ & $0,790 \%$ & $0,768 \%$ & $2,600 \%$ & $0,082 \%$ \\
\hline $\mathrm{Na}_{2} \mathrm{O}$ & $0,011 \%$ & $0,014 \%$ & $0,014 \%$ & $0,032 \%$ & $0,030 \%$ & $0,054 \%$ & $0,051 \%$ & $0,156 \%$ & $0,107 \%$ & $0,083 \%$ & $0,013 \%$ & $0,015 \%$ \\
\hline $\mathrm{K}_{2} \mathrm{O}$ & $0,503 \%$ & $0,559 \%$ & $0,873 \%$ & $0,950 \%$ & $0,800 \%$ & $0,867 \%$ & $0,835 \%$ & $0,922 \%$ & $0,877 \%$ & $0,904 \%$ & $0,935 \%$ & $0,875 \%$ \\
\hline $\mathrm{TiO}_{2}$ & $3,762 \%$ & $3,708 \%$ & $3,442 \%$ & $3,155 \%$ & $3,644 \%$ & $3,505 \%$ & $3,578 \%$ & $3,485 \%$ & $3,607 \%$ & $3,648 \%$ & $3,506 \%$ & $3,735 \%$ \\
\hline $\mathrm{P}_{2} \mathrm{O}_{5}$ & $0,157 \%$ & $0,155 \%$ & $1,574 \%$ & $1,355 \%$ & $0,354 \%$ & $0,940 \%$ & $0,422 \%$ & $0,511 \%$ & $0,150 \%$ & $0,141 \%$ & $0,226 \%$ & $0,157 \%$ \\
\hline $\mathrm{MnO}$ & $0,044 \%$ & $0,052 \%$ & $0,068 \%$ & $0,069 \%$ & $0,041 \%$ & $0,053 \%$ & $0,058 \%$ & $0,075 \%$ & $0,052 \%$ & $0,054 \%$ & $0,034 \%$ & $0,065 \%$ \\
\hline $\mathrm{SO}_{3}$ & $0,100 \%$ & $0,095 \%$ & $0,077 \%$ & $0,076 \%$ & $0,354 \%$ & $0,076 \%$ & $0,082 \%$ & $0,073 \%$ & $0,085 \%$ & $0,078 \%$ & $0,076 \%$ & $0,091 \%$ \\
\hline $\mathrm{Sr}$ & $0,0030 \%$ & $0,0040 \%$ & $0,0060 \%$ & $0,0070 \%$ & $0,0050 \%$ & $0,0090 \%$ & $0,0080 \%$ & $0,0190 \%$ & $0,0140 \%$ & $0,0110 \%$ & $0,0050 \%$ & $0,0030 \%$ \\
\hline $\mathrm{Rb}$ & $0,0040 \%$ & $0,0050 \%$ & $0,0070 \%$ & $0,0070 \%$ & $0,0070 \%$ & $0,0070 \%$ & $0,0070 \%$ & $0,0070 \%$ & $0,0070 \%$ & $0,0080 \%$ & $0,0080 \%$ & $0,0080 \%$ \\
\hline $\mathrm{Ni}$ & $0,0080 \%$ & $0,0080 \%$ & $0,0090 \%$ & $0,0090 \%$ & $0,0080 \%$ & $0,0080 \%$ & $0,0090 \%$ & $0,0090 \%$ & $0,0080 \%$ & $0,0090 \%$ & $0,0080 \%$ & $0,0080 \%$ \\
\hline $\mathrm{Cu}$ & $0,0070 \%$ & $0,0070 \%$ & $0,0070 \%$ & $0,0070 \%$ & $0,0070 \%$ & $0,0080 \%$ & $0,0080 \%$ & $0,0110 \%$ & $0,0100 \%$ & $0,0090 \%$ & $0,0070 \%$ & $0,0070 \%$ \\
\hline $\mathrm{Zn}$ & $0,0070 \%$ & $0,0070 \%$ & $0,0080 \%$ & $0,0080 \%$ & $0,0070 \%$ & $0,0070 \%$ & $0,0070 \%$ & $0,0080 \%$ & $0,0070 \%$ & $0,0070 \%$ & $0,0060 \%$ & $0,0070 \%$ \\
\hline $\mathrm{Zr}$ & $0,1600 \%$ & $0,1580 \%$ & $0,1390 \%$ & $0,1290 \%$ & $0,1360 \%$ & $0,1420 \%$ & $0,1450 \%$ & $0,1260 \%$ & $0,1410 \%$ & $0,1500 \%$ & $0,1480 \%$ & $0,1660 \%$ \\
\hline $\mathrm{Cr}$ & $0,0230 \%$ & $0,0220 \%$ & $0,0220 \%$ & $0,0200 \%$ & $0,0230 \%$ & $0,0210 \%$ & $0,0220 \%$ & $0,0200 \%$ & $0,0210 \%$ & $0,0220 \%$ & $0,0230 \%$ & $0,0220 \%$ \\
\hline V & $0,0230 \%$ & $0,0230 \%$ & $0,0210 \%$ & $0,0200 \%$ & $0,0220 \%$ & $0,0210 \%$ & $0,0220 \%$ & $0,0230 \%$ & $0,0240 \%$ & $0,0240 \%$ & $0,0220 \%$ & $0,0220 \%$ \\
\hline Co & $0,0010 \%$ & $0,0010 \%$ & $0,0010 \%$ & $0,0010 \%$ & $0,0010 \%$ & $0,0010 \%$ & $0,0010 \%$ & $0,0020 \%$ & $0,0020 \%$ & $0,0010 \%$ & $0,0010 \%$ & $0,0010 \%$ \\
\hline $\mathrm{Nb}$ & $0,0010 \%$ & $0,0100 \%$ & $0,0090 \%$ & $0,0080 \%$ & $0,0100 \%$ & $0,0090 \%$ & $0,0090 \%$ & $0,0080 \%$ & $0,0090 \%$ & $0,0090 \%$ & $0,0090 \%$ & $0,0110 \%$ \\
\hline $\mathrm{Pb}$ & $0,0160 \%$ & $0,0160 \%$ & $0,0150 \%$ & $0,0150 \%$ & $0,0160 \%$ & $0,0150 \%$ & $0,0150 \%$ & $0,0130 \%$ & $0,0140 \%$ & $0,0140 \%$ & $0,0150 \%$ & $0,0160 \%$ \\
\hline Total & $99,990 \%$ & $100,000 \%$ & $100,000 \%$ & $100,000 \%$ & $99,907 \%$ & $100,000 \%$ & $100,002 \%$ & $99,997 \%$ & $100,001 \%$ & $100,000 \%$ & $99,998 \%$ & $100,001 \%$ \\
\hline
\end{tabular}




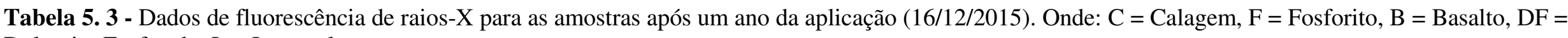
Dolomito Fosfatado, L = Latossolo.

\begin{tabular}{|c|c|c|c|c|c|c|c|c|c|c|c|c|}
\hline & RT - 01 & RT - 02 & RT - 03 & RT - 04 & RT - 05 & RT - 06 & RT - 07 & RT - 08 & RT - 09 & RT - 10 & RT - 11 & RT - 12 \\
\hline & NPK & $\mathrm{NPK}+\mathrm{C}$ & $F(120 \mathrm{~kg})$ & $F(120 \mathrm{~kg})+C$ & $\begin{array}{c}\mathrm{F}(60 \mathrm{~kg})+ \\
\mathrm{B}(80 \mathrm{~kg}) \\
\end{array}$ & $\begin{array}{c}F(60 \mathrm{~kg})+ \\
B(80 \mathrm{~kg})+C \\
\end{array}$ & $\begin{array}{c}\mathrm{F}(20 \mathrm{~kg})+ \\
\mathrm{B}(80 \mathrm{~kg}) \\
\end{array}$ & $\begin{array}{c}F(20 \mathrm{~kg})+ \\
B(80 \mathrm{~kg})+C\end{array}$ & $\mathrm{~B}(120 \mathrm{~kg})$ & $B(120 \mathrm{~kg})+C$ & $\mathrm{DF}(120 \mathrm{~kg})$ & $L$ \\
\hline $\mathrm{SiO}_{2}$ & $19,342 \%$ & $19,258 \%$ & $22,789 \%$ & $31,051 \%$ & $20,900 \%$ & $25,819 \%$ & $21,273 \%$ & $22,283 \%$ & $19,847 \%$ & $21,288 \%$ & $19,671 \%$ & $19,505 \%$ \\
\hline $\mathrm{Al}_{2} \mathrm{O}_{3}$ & $49,967 \%$ & $49,631 \%$ & $46,397 \%$ & $39,118 \%$ & $47,933 \%$ & $40,186 \%$ & $45,174 \%$ & $44,689 \%$ & $48,374 \%$ & $46,256 \%$ & $48,421 \%$ & $49,871 \%$ \\
\hline $\mathrm{MgO}$ & $0,080 \%$ & $0,338 \%$ & $0,224 \%$ & $0,507 \%$ & $0,291 \%$ & $0,784 \%$ & $0,382 \%$ & $0,619 \%$ & $0,268 \%$ & $0,613 \%$ & $0,472 \%$ & $0,149 \%$ \\
\hline $\mathrm{Fe}_{2} \mathrm{O}_{3}$ & $25,745 \%$ & $25,140 \%$ & $23,345 \%$ & $21,016 \%$ & $24,863 \%$ & $23,394 \%$ & $26,831 \%$ & $25,555 \%$ & $26,047 \%$ & $25,251 \%$ & $25,432 \%$ & $25,132 \%$ \\
\hline $\mathrm{CaO}$ & $0,055 \%$ & $0,823 \%$ & $1,414 \%$ & $2,104 \%$ & $0,705 \%$ & $3,309 \%$ & $0,729 \%$ & $1,477 \%$ & $0,411 \%$ & $1,292 \%$ & $0,942 \%$ & $0,101 \%$ \\
\hline $\mathrm{Na}_{2} \mathrm{O}$ & $0,011 \%$ & $0,012 \%$ & $0,012 \%$ & $0,046 \%$ & $0,043 \%$ & $0,067 \%$ & $0,085 \%$ & $0,086 \%$ & $0,055 \%$ & $0,136 \%$ & $0,014 \%$ & $0,013 \%$ \\
\hline $\mathrm{K}_{2} \mathrm{O}$ & $0,497 \%$ & $0,552 \%$ & $0,798 \%$ & $1,017 \%$ & $0,830 \%$ & $0,958 \%$ & $0,876 \%$ & $0,897 \%$ & $0,870 \%$ & $0,926 \%$ & $0,954 \%$ & $0,875 \%$ \\
\hline $\mathrm{TiO}_{2}$ & $3,778 \%$ & $3,696 \%$ & $3,483 \%$ & $2,975 \%$ & $3,609 \%$ & $3,324 \%$ & $3,818 \%$ & $3,579 \%$ & $3,634 \%$ & $3,678 \%$ & $3,575 \%$ & $3,758 \%$ \\
\hline $\mathrm{P}_{2} \mathrm{O}_{5}$ & $0,134 \%$ & $0,165 \%$ & $1,159 \%$ & $1,785 \%$ & $0,457 \%$ & $1,754 \%$ & $0,408 \%$ & $0,425 \%$ & $0,124 \%$ & $0,145 \%$ & $0,152 \%$ & $0,160 \%$ \\
\hline $\mathrm{MnO}$ & $0,040 \%$ & $0,043 \%$ & $0,058 \%$ & $0,090 \%$ & $0,040 \%$ & $0,076 \%$ & $0,060 \%$ & $0,054 \%$ & $0,035 \%$ & $0,069 \%$ & $0,031 \%$ & $0,062 \%$ \\
\hline $\mathrm{SO}_{3}$ & $0,086 \%$ & $0,086 \%$ & $0,076 \%$ & $0,069 \%$ & $0,070 \%$ & $0,072 \%$ & $0,077 \%$ & $0,076 \%$ & $0,073 \%$ & $0,081 \%$ & $0,076 \%$ & $0,098 \%$ \\
\hline $\mathrm{Sr}$ & $0,0030 \%$ & $0,0040 \%$ & $0,0050 \%$ & $0,0090 \%$ & $0,0070 \%$ & $0,0130 \%$ & $0,0100 \%$ & $0,0120 \%$ & $0,0070 \%$ & $0,0160 \%$ & $0,0030 \%$ & $0,0030 \%$ \\
\hline $\mathrm{Rb}$ & $0,0040 \%$ & $0,0050 \%$ & $0,0060 \%$ & $0,0070 \%$ & $0,0070 \%$ & $0,0080 \%$ & $0,0080 \%$ & $0,0070 \%$ & $0,0070 \%$ & $0,0080 \%$ & $0,0090 \%$ & $0,0080 \%$ \\
\hline $\mathrm{Ni}$ & $0,0090 \%$ & $0,0080 \%$ & $0,0080 \%$ & $0,0090 \%$ & $0,0090 \%$ & $0,0100 \%$ & $0,0090 \%$ & $0,0090 \%$ & $0,0090 \%$ & $0,0090 \%$ & $0,0080 \%$ & $0,0080 \%$ \\
\hline $\mathrm{Cu}$ & $0,0070 \%$ & $0,0070 \%$ & $0,0070 \%$ & $0,0060 \%$ & $0,0080 \%$ & $0,0080 \%$ & $0,0100 \%$ & $0,0090 \%$ & $0,0080 \%$ & $0,0110 \%$ & $0,0070 \%$ & $0,0070 \%$ \\
\hline $\mathrm{Zn}$ & $0,0070 \%$ & $0,0060 \%$ & $0,0070 \%$ & $0,0080 \%$ & $0,0070 \%$ & $0,0080 \%$ & $0,0080 \%$ & $0,0070 \%$ & $0,0060 \%$ & $0,0080 \%$ & $0,0060 \%$ & $0,0070 \%$ \\
\hline $\mathrm{Zr}$ & $0,1620 \%$ & $0,1570 \%$ & $0,1420 \%$ & $0,1200 \%$ & $0,1500 \%$ & $0,1350 \%$ & $0,1670 \%$ & $0,1470 \%$ & $0,1550 \%$ & $0,1450 \%$ & $0,1560 \%$ & $0,1700 \%$ \\
\hline $\mathrm{Cr}$ & $0,0230 \%$ & $0,0220 \%$ & $0,0210 \%$ & $0,0180 \%$ & $0,0210 \%$ & $0,0200 \%$ & $0,0210 \%$ & $0,0210 \%$ & $0,0220 \%$ & $0,0200 \%$ & $0,0220 \%$ & $0,0210 \%$ \\
\hline V & $0,0230 \%$ & $0,0230 \%$ & $0,0220 \%$ & $0,0200 \%$ & $0,0230 \%$ & $0,0220 \%$ & $0,0250 \%$ & $0,0220 \%$ & $0,0220 \%$ & $0,0240 \%$ & $0,0230 \%$ & $0,0240 \%$ \\
\hline Co & $0,0010 \%$ & $0,0010 \%$ & $0,0010 \%$ & $0,0020 \%$ & $0,0010 \%$ & $0,0020 \%$ & $0,0020 \%$ & $0,0010 \%$ & $0,0010 \%$ & $0,0020 \%$ & $0,0010 \%$ & $0,0010 \%$ \\
\hline $\mathrm{Nb}$ & $0,0100 \%$ & $0,0100 \%$ & $0,0090 \%$ & $0,0080 \%$ & $0,0100 \%$ & $0,0080 \%$ & $0,0110 \%$ & $0,0100 \%$ & $0,0100 \%$ & $0,0090 \%$ & $0,0100 \%$ & $0,0110 \%$ \\
\hline $\mathrm{Pb}$ & $0,0160 \%$ & $0,0150 \%$ & $0,0150 \%$ & $0,0160 \%$ & $0,0150 \%$ & $0,0150 \%$ & $0,0170 \%$ & $0,0150 \%$ & $0,0140 \%$ & $0,0130 \%$ & $0,0150 \%$ & $0,0160 \%$ \\
\hline Total & $100,000 \%$ & $100,002 \%$ & $99,998 \%$ & $100,001 \%$ & $99,999 \%$ & $99,992 \%$ & $100,001 \%$ & $100,000 \%$ & $99,999 \%$ & $100,000 \%$ & $100,000 \%$ & $100,000 \%$ \\
\hline P.F. & $25,32 \%$ & $24,21 \%$ & $23,46 \%$ & $20,86 \%$ & $23,11 \%$ & $22,93 \%$ & $23,95 \%$ & $23,55 \%$ & $23,29 \%$ & $23,41 \%$ & $25,24 \%$ & $25,83 \%$ \\
\hline
\end{tabular}

